\title{
Modulation of DNA repair : studies on the xenobiotic activation of poly(adenosine diphosphate ribosylation) in humans
}

Citation for published version (APA):

Stierum, R. H. (1996). Modulation of DNA repair : studies on the xenobiotic activation of poly(adenosine diphosphate ribosylation) in humans. [Doctoral Thesis, Maastricht University]. Rijksuniversiteit Limburg. https://doi.org/10.26481/dis.19960209rs

Document status and date:

Published: 01/01/1996

DOI:

10.26481/dis.19960209rs

Document Version:

Publisher's PDF, also known as Version of record

\section{Please check the document version of this publication:}

- A submitted manuscript is the version of the article upon submission and before peer-review. There can be important differences between the submitted version and the official published version of record.

People interested in the research are advised to contact the author for the final version of the publication, or visit the DOI to the publisher's website.

- The final author version and the galley proof are versions of the publication after peer review.

- The final published version features the final layout of the paper including the volume, issue and page numbers.

Link to publication

\footnotetext{
General rights rights.

- You may freely distribute the URL identifying the publication in the public portal. please follow below link for the End User Agreement:

www.umlib.nl/taverne-license

Take down policy

If you believe that this document breaches copyright please contact us at:

repository@maastrichtuniversity.nl

providing details and we will investigate your claim.
}

Copyright and moral rights for the publications made accessible in the public portal are retained by the authors and/or other copyright owners and it is a condition of accessing publications that users recognise and abide by the legal requirements associated with these

- Users may download and print one copy of any publication from the public portal for the purpose of private study or research.

- You may not further distribute the material or use it for any profit-making activity or commercial gain

If the publication is distributed under the terms of Article $25 \mathrm{fa}$ of the Dutch Copyright Act, indicated by the "Taverne" license above, 
Het verschijnen van dit proefschrift werd mede mogelijk gemaakt door de financiële steun van de Stichting Dr. Ir. J.H.J. van de Laar en de Johan Vermeij Stichting 


\section{MODULATION OF DNA REPAIR}

Studies on the xenobiotic activation of poly(adenosine diphosphate ribosylation) in humans 


\title{
MODULATION OF DNA REPAIR
}

\author{
Studies on the xenobiotic activation of \\ poly(adenosine diphosphate ribosylation) \\ in humans
}

\section{PROEFSCHRIFT}

ter verkrijging van de graad van doctor aan de Rijksuniversiteit Limburg te Maastricht, op gezag van de Rector Magnificus, Prof. mr. M.J. Cohen, ingevolge het besluit van het College van Dekanen, in het openbaar te verdedigen op vrijdag 9 februari 1996 om 16.00 uur

door

Robertus Henricus Stierum

geboren te Geldrop op 25 maart 1968 


\section{Promotor:}

Prof. dr. J.C.S. Kleinjans

\section{Co-promotor:}

Dr. ir. G.J. Hageman

\section{Beoordelingscommissie:}

Prof. dr. J.P.M. Geraedts, voorzitter

Dr. W.A. Buurman

Prof. dr. J.H.J. Hoeijmakers (Erasmus Universiteit Rotterdam)

Prof. dr. ir. P.H.M. Lohman (Rijksuniversiteit Leiden)

Prof. dr. F.C.S. Ramaekers

Stierum, Robertus, Henricus

Modulation of DNA repair: Studies on the xenobiotic activation of poly (adenosine dipbospbate ribosylation) in bumans / Stierum, Robertus, Henricus. - Maastricbt: Unigraphic, Rijksuniversiteit Limburg.

ISBN 90-5681-003-0

Subject beadings: DNA berstel / poly (adenosine difosfaat ribosylering) / genetische toxicologie / nicotinezuur / witte bloedcellen / benzo [a]pyreen toxiciteit

Druk: Unigrapbic, Rijksuniversiteit Limburg. Maastricbt 
...Hey I hope it's true what my wife said to me She says,

baby, it's the Beginning of a Great Adventure...

(Lou Reed, New York, 1989) 


\section{Contents}

\section{Abbreviations}

Chapter 1 Introduction 11

1.1 Chemical carcinogenesis. A historical overview 11

1.2 The multi-stage model of chemical carcinogenesis 11

$\begin{array}{lll}1.3 & \text { DNA damage } & 13\end{array}$

1.4 DNA repair 14

1.4.1 DNA alkyltransferases $\quad 15$

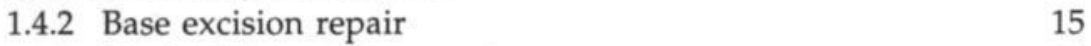

$\begin{array}{ll}\text { 1.4.3 Nucleotide excision repair } & 16\end{array}$

$\begin{array}{ll}\text { 1.4.4 Factors influencing DNA repair in humans } & 19\end{array}$

1.5 Poly(ADP-ribosylation) and niacin metabolism 20

1.5.1 Poly(ADP-ribosylation). The enzymatic process 20

1.5.2 Poly(ADP-ribosylation). Induction by DNA strand breakinducing agents 22

1.5.3 Poly(ADP-ribosylation). Proposed functions with regard to cellular responses to DNA damage 23

1.5.4 Poly(ADP-ribosylation). Relation to carcinogenesis 25

1.5.5 Niacin metabolism 26

1.5.6 Niacin metabolism. Importance with regard to modulation of poly(ADP-ribosylation), DNA repair and cancer risk 27

$\begin{array}{lll}1.6 & \text { The adaptive response } & 28\end{array}$

1.6.1 The adaptive response. A phenomenon reflecting the ex vivo induction of DNA repair mechanisms 28

1.6.2 Possible involvement of poly(ADP-ribose) polymerase in the adaptive response to ionizing radiation 32

1.7 DNA damage and p53 accumulation 32

1.7.1 A role for wild-type p53 tumour suppressor protein in modulating the persistence of DNA damage

1.7.2 Poly(ADP-ribose) polymerase. Possible involvement in DNA damage inducible pathways of p53 accumulation ? $\quad 35$

1.8 Benzo[a]pyrene and its reactive diolepoxides 36

1.8.1 Benzo[a]pyrene and its reactive diolepoxides. Model compounds to study DNA damage, DNA repair, mutagenicity and carcinogenicity

1.8.2 Interactions of ( \pm )-anti-benzo[a]pyrene diolepoxide with DNA

1.8.3 Repair of ( \pm )-anti-benzo[a]pyrene diolepoxideinduced DNA damage

1.9 Aims and outline of this thesis 
Chapter 2 Measurement by ${ }^{32} \mathrm{P}$ postlabeling of ( \pm -antibenzo[a]pyrene-diolepoxide- $\mathrm{N}^{2}$-deoxyguanosine adduct persistence in unstimulated human peripheral blood lymphocytes

Chapter 3 Increased poly(ADP-ribose) polymerase activity during repair of $( \pm)$-anti-benzo[a]pyrene diolepoxide-induced DNA damage in human peripheral blood lymphocytes in vitro

Chapter 4 Effect of nicotinic acid supplementation on niacin status in relation to cytogenetic damage and ex vivo ( \pm )-antibenzo[a]pyrene diolepoxide-induced DNA repair in smoking humans

Chapter 5 Age-related negative associations between parameters of cytogenetic damage and ex vivo ( \pm )-anti-benzo[a]pyrene diolepoxide-induced unscheduled DNA synthesis in smoking humans

Chapter $6 \quad( \pm)$-anti-benzo[a]pyrene diolepoxide-induced adaptive response in human peripheral blood lymphocytes is not associated with enhanced induction of poly(ADP-ribosylation)

Chapter 7 Inhibition of poly(ADP-ribose) polymerase increases ( \pm -anti-benzo[a]pyrene diolepoxide-induced micronuclei formation and p53 accumulation in isolated human peripheral blood lymphocytes

Chapter 8 General discussion

Summary

Samenvatting

Dankwoord

Curriculum vitae 


\section{Abbreviations}

3-AB

act D

ADP

(士)-anti-BPDE

AP

A R

A T

ATP

$\mathrm{B}[\mathrm{a}] \mathrm{P}$

BEAS

BER

BLM

BrdU

BSA

C

CA

cdk

CS

CT

cyt B

dG

DHB-Biorex

DMS

DMSO

ENU

EO

$\varepsilon$ Rado

FCS

G

HPRT

HT

HTO

IR

LI

M

MMC

MMS

$\mathrm{MN}$ 3-aminobenzamide

actinomycin D

adenosine diphosphate

$( \pm)$-anti-benzo[a]pyrene diolepoxide: $( \pm)-7 \beta, 8 \alpha$-dihydroxy$9 \alpha, 10 \alpha$-epoxy-7,8,9,10-tetrahydrobenzo[a]pyrene apurinic/apyrimidinic

adaptive response

ataxia-telangiectasia

adenosine triphosphate

benzo[a]pyrene

SV40-immortalized BEAS-2B human bronchial epithelial cells

base excision repair

bleomycin

bromodeoxyuridine

bovine serum albumine

challenge

chromosomal aberrations

cyclin-dependent kinase(s)

Cockayne's syndrome

$\left[{ }^{14} \mathrm{C}\right]$ thymidine

cytochalasin B

deoxyguanosine

dihydroxyboryl Bio-Rex

dimethylsulfate

dimethylsulfoxide

$N$-ethyl- $N$-nitrosourea

ethylene oxide

ethenoribosyladenosine

foetal calf serum

guanine

hypoxanthine guanine phosphoribosyltransferase

hyperthermia

tritiated water

ionizing radiation

labeling index

mutations

mitomycin C

methylmethanesulfonate

micronuclei 


$\begin{array}{ll}\text { MNU } & N \text {-methyl- } N \text {-nitrosourea } \\ \text { MNNG } & N \text {-methyl- } N^{\prime} \text {-nitro- } N \text {-nitrosoguanidine } \\ \text { MTT } & \text { 3-[4,5-dimethylthiazol-2-yl]-2,5-diphenyltetrazolium } \\ \text { bromide } & N \text {-acetoxy- } N \text {-acetylaminofluorene } \\ \text { N-AAAF } & \text { N-acetylaminofluorene } \\ \text { N-AAF } & \text { nicotinamide adenine dinucleotide } \\ \text { NAD } & \text { niacin equivalent: the dietary amount of niacin precursors } \\ \text { NE } & \text { equivalent to } 1 \text { mg of nicotinic acid (60 mg tryptophan 1 } \\ & \text { mg nicotinic acid 1 NE) } \\ \text { NER } & \text { nucleotide excision repair } \\ \text { NQO } & \text { 4-nitroquinoline- } 1 \text {-oxide } \\ \text { PADPR } & \text { poly(adenosine diphosphate ribosylation) } \\ \text { PADPRT } & \text { poly(adenosine diphosphate ribose) polymerase: } \\ \text { PAH } & \text { NAD }{ }^{+} \text {ADP-ribosyltransferase (EC 2.4.2.30) } \\ \text { PBLs } & \text { polycyclic aromatic hydrocarbon(s) } \\ \text { PBS } & \text { human peripheral blood lymphocytes } \\ \text { PHA } & \text { phosphate buffered saline } \\ \text { PT } & \text { phytohemagglutinin } \\ \text { SCE } & \text { pre-treatment } \\ \text { SDS } & \text { sister chromatid exchange } \\ \text { TG } & \text { sodium dodecyl sulphate } \\ \text { TT } & \text { 6-thioguanine resistent } \\ \text { TTD } & \text { [3H]thymidine } \\ \text { UDS } & \text { trichothiodystrophy } \\ \text { unscheduled DNA synthesis } & \text { ultraviolet light } \\ \text { VF } & \text { variant frequency } \\ \text { XP } & \text { xeroderma pigmentosum } \\ & \end{array}$





\section{Introduction}

\subsection{Chemical carcinogenesis. A historical overview}

Cancer. The word originates from the Grecian civilization, referring to the invasive character of carcinomas into surrounding tissues with the arms and pincers of a lobster or a crab (Greece: Karkinos, Latin: Cancer).

About two thousand years later, it became apparent that exposure to chemicals could be a causal factor in the development of cancer. In 1761, Hill suggested the existence of a relation between use of tobacco snuff and nasal cancer. A few years later, in 1775, the London surgeon Pott tried to relate his observation of high incidence of scrotum cancer in young chimney sweeps to soot exposure. In 1895, Rehn reported associations between chronic exposure to aromatic amines and urinary bladder cancer in humans working in the dye industry. In the beginning of the 20th century, the first studies on experimental chemical carcinogenesis were performed. In 1915, two Japanese pathologists, Yamagawa and Ichikawa, showed that topical application of coal tar to the ears of rabbits resulted in the induction of skin carcinomas. Some years later, Kennaway and Hieger (in 1930) and Cook (in 1933) identified dibenz[a,h]anthracene and benzo[a]pyrene (B[a]P) as carcinogenic polycyclic aromatic hydrocarbons (PAH) present in coal tar (reviewed in 1). Since 1940, a large number of other carcinogenic chemical substances has been identified. Some examples are vinyl chloride and ethyl carbamate, aflatoxin B1, bis(chloromethylether), $\mathrm{N}$-acetylaminofluorene $(\mathrm{N}$ $\mathrm{AAF})$, dimethylnitrosoamine, aflatoxins and various PAH. Today, it is believed that besides genetic factors, infectious organisms and ionizing radiation (IR), various environmental factors, such as tobacco smoke, alcohol consumption, dietary factors, sexual habits, reproductive factors, and occupational exposure to chemicals all attribute to the causation of cancer in humans (2). Although some of these factors cannot be classified as true chemical carcinogens themselves, it is quite certain that chemicals are involved in the ways these factors may cause cancer.

\subsection{The multi-stage model of chemical carcinogenesis}

In the period between 1940 and 1950, in parallel with the discovery of numerous carcinogens, an important finding was that the process of (chemical) carcinogenesis consisted of more than one stage (reviewed in 1). Further, Miller and Miller (3) proposed that the majority of chemical carcinogens are directly, or 
after metabolization to electrophylic intermediates, capable of reacting with cellular macromolecules such as DNA. Their hypothesis was a major breakthrough in the understanding of chemical carcinogenesis. Since the beginning of the eighties, the complex process of cancer development has essentially been divided into three stages: initiation, promotion and progression. During initiation, a process which is irreversible, normal cells are converted to neoplastic cells. The first step in this process is the interaction of electrophylic compounds with DNA. A critical following step is DNA replication, in which misincorporation of a nucleotide takes place opposite to the damaged base. This results in a DNA molecule with an altered nucleotide sequence in the newly synthesized daughter strand. After subsequent mitosis, cell division and DNA replication - using the altered daughter strand in one of the (first-generation) daughter cells as replication template - a second cell division will ultimately result in formation of one (second-generation) daughter cell with a DNA molecule, in which both strands contain an altered sequence. The latter process is called DNA mutation-fixation. In this way, a single base-pair within the coding region (exon) of a gene may be substituted by a different one, which is called point-mutation. In addition, DNA polymerases may fail to incorporate any, or incorporate additional nucleotides opposite to a damaged nucleotide in the template strand. Consequently, one ore more nucleotides will be gained or lost from the resulting daughter strand leading to so called frame-shift mutations in coding regions. Besides gene mutations, other alterations such as deletions, gene amplifications or rearrangements may result from interaction of carcinogens with macromolecules and contribute to initiation or subsequent steps in carcinogenesis.

Promotion can be characterized as the (reversible) clonal outgrow of initiated cells into neoplasms. Loss of several factors that regulate normal cell proliferation is believed to be responsible for this process. An examples is loss of intercellular communication. Continued exposure to agents (promotors) that stimulate cellular proliferation, is believed to be responsible for tumour promotion.

Progression is the final stage of carcinogenesis, during which benign or malignant neoplasms can be characteristically seen. Additional genetic alterations accumulate, such as karyotypic changes. These changes are directly related to the increased growth rate, invasiveness, metastatic capability and biochemical changes in the neoplastic cell. The process of progression is presumed to be irreversible (reviewed in 1).

In particular, alterations in growth-regulatory proto-oncogenes and tumour suppressor genes are believed to be responsible for tumorigenesis. Protooncogenes, initially identified as genes of acutely transforming (retro)viruses, are genes that are involved in regulation of normal cell proliferation. Their gene products are components of cellular signalling pathways of growth stimulatory 
signals, such as hormones, hormone receptors, cytoplasmic signalling proteins and nuclear factors. Alterations in proto-oncogenes, such as point mutations, chromosome translocations, gene amplification or aberrant 5-methylcytosine methylation may lead to aberrant gene products or alternatively, to enhanced gene expression. Ultimately, these changes may result in acceleration of cell division. In addition, loss of normal tumour suppressor genes is believed to attribute to carcinogenesis. Tumour suppressor genes code for proteins that inhibit cell proliferation by arresting progression through the cell cycle, blocking differentiation or inducing senescence or cell death $(4,5)$. Although the nature and order of appearance during tumorigenesis is not fully understood, it is believed that cumulative alterations in both oncogenes and tumour suppressor genes are crucial for tumorigenesis (6).

\subsection{DNA damage}

As mentioned, Miller and Miller (3) proposed that the majority of carcinogens are themselves electrophylic intermediates (direct carcinogens) or first need to be converted to reactive metabolites (pro-carcinogens or pre-carcinogens). At present, indeed numerous carcinogens are known which either directly or indirectly interact with DNA. Without the intention of giving an exhausting complete enumeration, examples illustrating the wide spectrum of interactions of various carcinogens with DNA are given below.

Sulfate esters, like dimethylsulfate (DMS) and methylmethanesulfonate (MMS) and nitrosoamides and nitrosoureas, like $N$-methyl- $N$-nitrosourea (MNU) and $N$-methyl- $N^{\prime}$-nitro- $N$-nitrosoguanidine (MNNG), may transfer methyl- or higher alkylgroups towards oxygen and nitrogen atoms of nucleotides. Examples of these small adducts are $\mathrm{O}^{6}$-alkylguanine; N7alkylguanine; 3-alkyladenine; $\mathrm{O}^{4}$-alkylthymine and phosphotriesters. Reaction of DNA with $N$-hydroxylated metabolites from aromatic amines like $N$-AAF, 1naphtylamine, 2-naphtylamine, 4-aminobiphenyl and benzidine, may primarily yield large adducts on $\mathrm{C} 8$ and $\mathrm{N}^{2}$ of deoxyguanosine (dG), but also on $\mathrm{O}^{6}$ of dG and N7 of deoxyadenosine. Diolepoxide intermediates of PAH like B[a]P, dibenzo[a,h]pyrene, 7,12-dimethylbenzo[a]anthracene, benzo[a]anthracene and chrysene form large covalent adducts with DNA $(7,8)$. An example is the adduct between the 2-aminogroup of guanine and the C10 position of $B[a] P(9,10)$. Interaction of reactive metabolites from fungal and plant toxins like aflatoxins and safrole, may yield large unstable adducts on N7 of guanine and $\mathrm{N}^{2}$ of guanine and $\mathrm{N}^{6}$ of adenine respectively (11). Small exocyclic (etheno-bridged) DNA adducts may be formed on adenine, cytosine and guanine bases, as a consequence of interactions between DNA and vinyl compounds like vinyl chloride monomer, halogenated aldehydes like chloro- and bromo-acetaldehyde and non-radical lipid peroxidation products like trans-4-hydroxy-2-nonenal (12). 
In addition to chemicals, physical agents may also induce via chemical intermediates DNA damage. Ultraviolet light (UV) causes formation of cyclobutane pyrimidine dimers, pyrimidine-pyridone 6-4 photoproducts and pyrimidine hydrates $(13,14)$. Ionizing radiation, like $\gamma$-rays, $X$-rays, $\beta$-particles and radon ( $\alpha$-particles) may cause, via hydroxyl radical intermediates, formation of oxidized bases like 8-oxoguanine, 5-hydroxycytosine and thymine glycol; damaged bases like pyrimidine imidazole ring open products; damaged deoxyribose moieties and DNA single and double strand breaks (15-17). Finally, active oxygen species, formed by exposure to mineral dusts like asbestos or coal mine dust, may generate a variety of modified bases (18).

\subsection{DNA repair}

From an evolutionary point of view, changes in the genetic code are necessary to attribute to the diversity and survival of species. At the individual level however, it is absolutely required to retain the integrity of DNA prior to DNA replication, DNA transcription and cell division. In order to maintain this genetic integrity, prokaryotic and eukaryotic cells possess DNA repair systems. As a matter of course, it can be imagined that without any repair, every carcinogenDNA interaction potentially may lead to a genetic alteration and thus ultimately to cell-death, the onset of carcinogenesis or other aberrant phenomena like birth defects. The clearest example illustrating that defective DNA repair is associated with carcinogenesis, is the high incidence of skin cancer seen in patients with xeroderma pigmentosum (XP). Individuals affected by this disease have a marked inability to perform nucleotide excision repair (NER) of cyclobutane pyrimidine dimers and pyrimidine-pyridone 6-4 photoproducts induced by UV $(19,20)$. In addition, in mammalian cells treated ex vivo with DNA damaging carcinogens, negative associations have been found between the extent of DNA repair and the extent of mutagenesis (21-24).

At present, several mechanisms of pre-replicational DNA repair are known in mammalians, like DNA alkyltransferases, base excision repair (BER) and nucleotide excision repair (NER). Besides pre-replicational repair, other repair mechanisms, such as mismatch repair ensures the restoration of misincorporated nucleotides, after normal DNA replication. This particular repair mechanism, known for years in $E$. coli, has been recently characterized in humans (25-29). Detailed discussion of post-replicational repair mechanisms are beyond the scope of this Thesis. However, it has to be mentioned that defects in the human mismatch repair gene $h \mathrm{MSH} 2$ were recently associated with hereditary nonpolyposis colorectal cancer $(26,28)$, thus highly emphasizing the importance of accurate DNA repair in prevention of human carcinogenesis. 


\subsubsection{DNA alkyltransferases}

DNA alkyltransferases are proteins capable of repair of alkylated DNA bases. The main characteristic of these group of proteins is the direct transfer, without base or nucleotide removal, of alkylgroups from damaged bases towards sulfhydrylgroup-containing cysteine residues within the protein. After this transfer, the binding site of the protein is not regenerated. Instead, repair via this pathway is dependent on de novo synthesis of additional alkyltransferase. In $E$. coli, two DNA alkyltransferases have been identified: the inducible Ada protein and the constitutive Ogt ( $\mathrm{O}^{6}$-alkylguanine DNA alkyltransferase) protein. Other prokaryotic alkyltransferases have been identified as well. These alkyltransferases are capable of removing alkylgroups from $\mathrm{O}^{6}$-methylguanine, $\mathrm{O}^{4}$ methylthymine and methyl phosphotriesters (30-32). In mammalians (human and rat), only the $\mathrm{O}^{6}$-alkylguanine DNA alkyltransferase has been characterized in detail (33-35). Besides removal of methyl groups from the $\mathrm{O}^{6}$-position of guanine, the mammalian alkyltransferase can also remove ethyl, n-propyl, 2chloroethyl, n-butyl, isopropyl, isobutyl and 2-hydroxyethyl groups (32). In contrast to prokaryotic alkyltransferases, the mammalian $\mathrm{O}^{6}$-alkylguanine DNA alkyltransferase lacks methyl phosphotriester methyltransferase activity. Further, it is unlikely that repair of alkylated exocyclic oxygen atoms on thymine proceeds via the $\mathrm{O}^{6}$-alkylguanine DNA alkyltransferase $(32,36)$.

\subsubsection{Base excision repair}

During BER, the combined action of several enzymes is required to replace a damaged base by its undamaged counterpart. Two classes of enzymes are involved in BER of modified DNA bases: DNA glycosylases and apurinic/apyrimidinic (AP) endonucleases. Some enzymes called DNAglycosylase-AP endonucleases possess the combined action of both enzymes. DNA glycosylases are enzymes with a narrow substrate specificity, which recognize a damaged or unusual base. They catalyze hydrolysis of the $N$ glycosilic bond between the modified base and the deoxyribose group. Several prokaryotic DNA glycosylases have been identified. Examples are the uracil-DNA $N$-glycosylase, recognizing uracil originating from deaminated cytosine and 3methyladenine-DNA $N$-glycosylases, recognizing besides 3-methyladenine also 3-methylguanine, 7-methylguanine, $\mathrm{O}^{6}$-methylguanine and $\mathrm{O}^{2}$-methylcytosine. Further, the formamidopyrimidine-DNA $N$-glycosylase recognizes the imidazole-ring open products of guanine and adenine. These products may arise from unstable adducts formed after hydroxyl radical attack on guanine and adenine (4,6-diamino-5-formamidopyrimidine and 2,6-diamino-4-hydroxy-5formamidopyrimide) or alkylation at N7 of guanine (2,6-diamino-4-oxy-5(methylformamido)pyrimidine) $(15,30)$. Hypoxanthine-DNA $N$-glycosylase 
recognizes hypoxanthine, that results either from physiological deamination of adenine or interaction of DNA with chemical agents like nitrous acid. Finally, hydroxymethyluracil-DNA $N$-glycosylase recognizes hydroxymethyluracil, produced by hydroxyl radical attack on the methylgroup of thymine $(15,37)$. Similar DNA glycosylase activities have been identified in mammalians, including humans $(15,30,37)$ although the enzymes themselves have not been all purified and characterized in detail yet.

Besides enzymatic removal of the damaged base by a DNA glycosylase, apurinic or apyrimidinic sites may also arise from spontaneous cleavage of the $\mathrm{N}$-glycosylic bond between the deoxyribose group and the damaged base. This bond may become unstable upon alkylation (30) or hydroxyl radical attack (15).

The non-enzymatically or enzymatically generated AP sites are substrates for AP endonucleases. These enzymes, which can be categorized into four classes, incise either on $3^{\prime}$ or $5^{\prime}$ side of the abasic sugar residue, leaving on both sites $3^{\prime}$ $\mathrm{OH}$ and $5^{\prime}-\mathrm{P}$ or $3^{\prime}-\mathrm{P}$ and $5^{\prime}-\mathrm{OH}$ termini, respectively (30). Prokaryotic APendonucleases of all four classes have been identified $(30,37)$. Further, human $\mathrm{Mg}^{2+}$-dependent AP endonucleases have been purified from Hela cells, fibroblasts and placenta $(30,37)$. The nick in the phosphodiester linkage (or the one-nucleotide gap resulting from $\beta$-elimination of the 5 -incised nucleotide or from enzymatic removal by an exonuclease) is recognized by a DNA polymerase which fills the gap with a new nucleotide. Finally, a DNA ligase restores the phosphodiester bond between the newly incorporated nucleotide and the nucleotide, already present. Recently, Dianov and Lindahl (38) reconstituted a BER excision repair pathway in vitro using the purified $E$. coli proteins UracilDNA glycosylase, AP endonuclease IV, a protein called RecJ capable of removing the abasic deoxyribose-phosphate residue, DNA polymerase I and DNA ligase. Interestingly, in absence of RecJ, a minor pathway of BER was also found to occur, during which DNA polymerase I cuts out (due to its 5 ' nuclease activity) and replaces a short (abasic) deoxyribosephosphate residue-containing oligonucleotide with new nucleotides, followed by action of DNA ligase (38).

\subsubsection{Nucleotide excision repair}

In contrast to BER which act on minor DNA adducts, NER mechanisms mainly act on larger DNA adducts. Examples are UV-induced cyclobutane pyrimidine dimers and pyrimidine-pyridone 6-4 photoproducts. Further, DNA containing large adducts from chemicals like cisplatin, mitomycin $\mathrm{C}, \mathrm{B}[\mathrm{a}] \mathrm{P}$, psoralen, $\mathrm{N}$ $\mathrm{AAF}$ and 4-nitroquinoline are substrate for NER mechanisms (37,39-41). Given the heterogeneous substrate range for NER mechanisms, recognition of damage can not simply rely on a binary recognition mechanism in which enzymesubstrate binding is accomplished through complementary surfaces. Instead, the activity of NER mechanisms results from sequential and partly overlapping 
activities of several DNA-binding polypeptides, requiring the energy released from hydrolysis of adenosine triphosphate (ATP).

The most extensively studied and best understood mechanism of NER is the Uvr(A)BC exinuclease system from E. coli. In this prokaryote, NER involves the concerted action of several polypeptides. First, in presence of ATP, a complex of two UvrA proteins is formed. Subsequently, this dimer complexes with an UvrB protein, recognizes the damaged nucleotides and binds near to the lesion with DNA. Then, the UvrA2B complex locally unwinds the DNA, due to its $5^{\prime}-->3^{\prime}$ helicase activity, and scans for major helix distortions. When a particular large lesion is encountered, the UvrA2 homodimer dissociates from the heterotrimer. UvrB tightly binds to and locally denaturates the DNA, in an ATP-dependent manner. Then, the UvrC protein complexes with UvrB. Upon binding with UvrC, UvrB catalyzes the hydrolysis of the 5th phosphodiester bond on the 3'side of the lesion. This incision step causes a conformational change in the UvrBC complex, which allows the UvrC protein to catalyze hydrolysis of the 8th phosphodiester bond in 5'-direction from the lesion. UvrC dissociates from the complex and subsequent combined action of UvrD, with DNA unwinding properties, and DNA polymerase I results in removal of a 12-13 oligomer containing the damaged nucleotide(s) and refilling the excision gap with new nucleotides opposite to the undamaged template. Finally, a DNA ligase restores the final open phosphodiester bond. $(20,30,37,42,43)$. Additional factors may be involved in the E. coli $\operatorname{Uvr}(\mathrm{A}) \mathrm{BC}$ exinuclease system. For example, the mfdgene product dissociates RNA polymerase molecules, stalled at DNA lesions and facilitates UvrA binding, thus being a transcription-repair coupling factor $(44,45)$.

In contrast to the $E$. coli $\operatorname{Uvr}(\mathrm{A}) \mathrm{BC}$ exinuclease system, the human NER mechanism is much more complex and less well understood. In humans, three clinical syndromes are known, which are related to deficiencies in NER. Besides $\mathrm{XP}$, patients with Cockayne's syndrome (CS) or Trichothiodystrophy (TTD) also have repair defects and are also sensitive to UV (46). In the past years, most genes and gene products involved in these human syndromes have been characterized. Defects in at least seven genes (XPA up to and including XPG, that are called complementation groups) have been found to be responsible for XP. Fusion of cells from each of these NER-deficient complementation groups with cells from another NER-deficient complementation group was found to result in cell hydrids with normal UV-inducible repair capacity. At least two complementation groups and thus genes (CSA and CSB) are involved in CS, while defects in the TTDA gene or (surprisingly) XPB and XPD genes contribute to TTD. In parallel to these findings, NER genes have been characterized in two yeast species, S. cerevisiae (RAD genes) and S. pombe (rad genes). Further, certain human genes (called ERCC genes, for Excision $\underline{R}$ epair $\underline{C}$ ross Complementing) have been isolated that were found to correct UV-induced repair in repair-deficient rodents. A remarkable structural and functional homology appears to exist between these eukaryotic gene products. For example, 


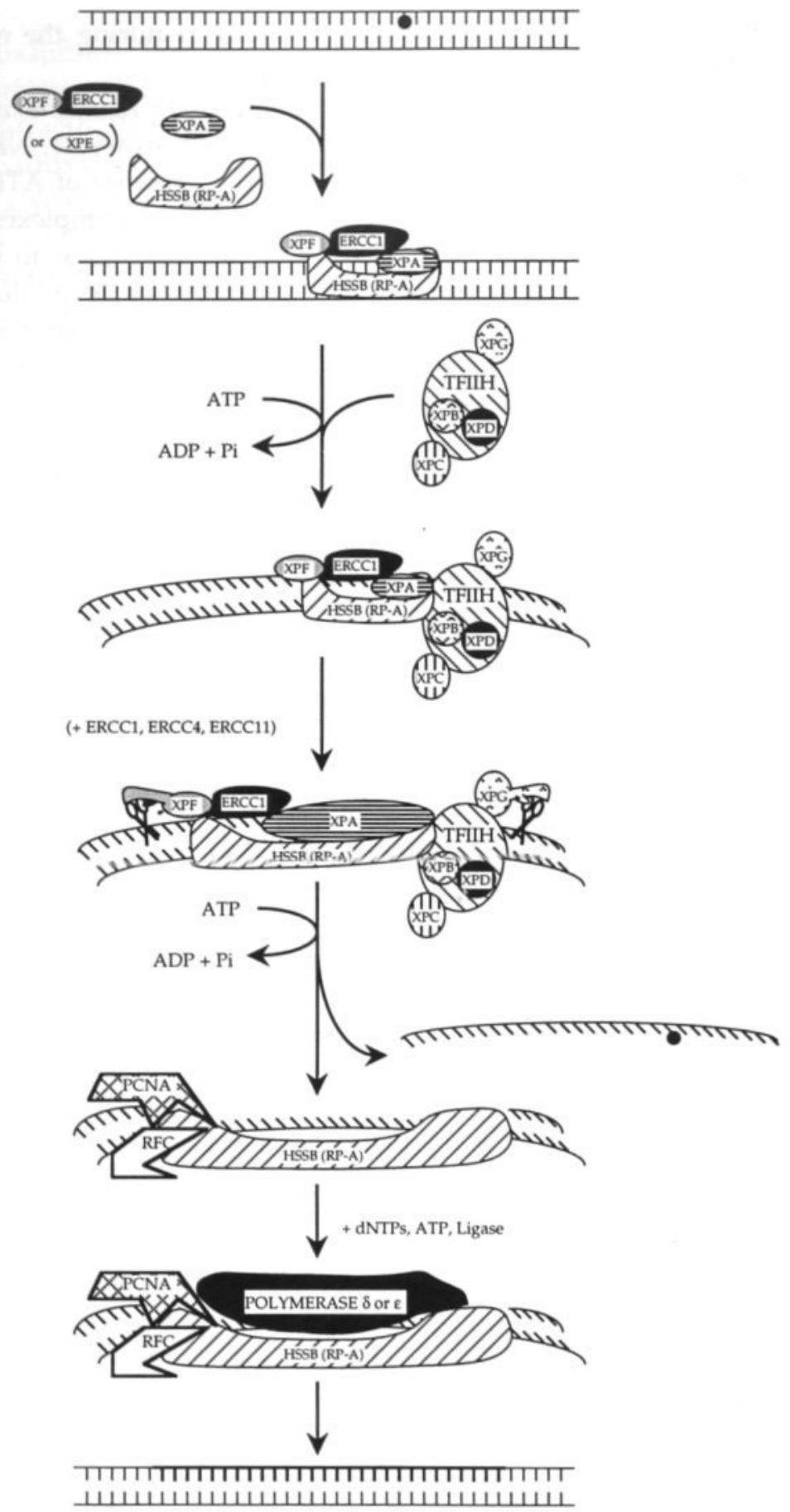

Figure 1.1. Proposed mechanism of human nucleotide excision repair (according to ref. 20,46-48). 
the human XPD gene product turned out to be similar to ERCC2 (rodent), RAD3 (S. cerevisiae) and rad15 (S. pombe). Thus NER genes seem to be highly conserved during evolution. Based on these findings, the human NER mechanism is now becoming elucidated and recently a model has been proposed (Figure 1.1). (20,46-48).

It is believed that at least 17 polypeptides are involved in human NER. The first step which takes place is damage recognition by the XPA protein complexed to XPF-ERCC1 proteins or to the XPE protein. This complex of proteins is stabilized by the HSSB (RP-A) replication protein and binds to DNA near the lesion site. Secondly, local unwinding of DNA takes place by a complex of proteins consisting of XPB, XPG (which have both a helicase activity) and the transcription factor TFIIH. This complex is recruited by the XPA protein towards the DNA-bound XPA/XPF-ERCC1(XPE)/HSSB protein complex. XPG and XPC proteins are also tightly associated with TFIIH, or alternatively are directed to the complex. The next step involves dual incision of the damaged template 5 phosphodiester bonds in 3'-direction by the XPG protein, and 24 phosphodiester bonds in 5'-direction by the XPF (+ ERCC1, ERCC4, ERCC11) proteins. In this manner, a damaged oligomer of approximately 27 to 29 nucleotides is released. In a similar way as for the $\operatorname{Uvr}(\mathrm{A}) \mathrm{BC}$ exinuclease system, a DNA polymerase ( $\varepsilon$ or $\delta$ ) fills in the excision gap (in $5^{\prime}-->3^{\prime}$ direction) and a DNA ligase restores the final open phosphodiester bond. In addition, other factors (proliferating cell nuclear antigen (PCNA) and perhaps the RFC replication protein) may be needed to facilitate release of the damaged oligomer and DNA bound repair proteins $(49,50)$. Recently, this mammalian nucleotide excision repair system was reconstituted in vitro with purified protein components of factors mentioned (252) and with an additional new factor called IF7.

\subsubsection{Factors influencing DNA repair in humans}

In humans, DNA repair mechanisms are certainly controlled by specific genetic factors, as is evidently illustrated by the genetically-based DNA repair deficiencies discussed. Moreover, other endogenous and exogenous factors may influence human DNA repair as well. Most of this evidence comes from large scale population-based studies in which DNA repair synthesis is measured as unscheduled (non-replicative) DNA synthesis (UDS), induced ex vivo in peripheral blood lymphocytes (PBLs) by DNA damaging agents. For example, DNA repair has been negatively (51-54), positively (52) or not at all associated with age (55-57). Further, in chronic alcoholics, ex vivo MNU-induced repair synthesis was found to be reduced in comparison to controls (58). In contrast, Madden et al. (55) observed no association between alcohol consumption and UV-induced repair synthesis. In the latter study, considerably reduced repair synthesis was observed in heroin addicts, which, remarkably, was reversed to normal control levels upon methadone treatment (55). In addition, DNA repair 
has been negatively $(55)$ or positively $(59,60)$ related or has been shown not to be related at all to smoking of tobacco $(56,61)$. Further, cells obtained from patients with Altzheimer's disease showed decreased repair of alkylation damage (62). Occupational exposure to chemicals may also modulate DNA repair activities. PBLs obtained from individuals exposed to propylene oxide and ethylene oxide (EO) (63) or individuals working in the rubber industry (56) showed decreased repair synthesis, in comparison to controls. Celotti et al. (64) did not observe any effect of occupational exposure to anti-neoplastic drugs on ex vivo-induced DNA repair.

Thus, varying results have been reported regarding the effects of these factors on repair. Part of this variation could be attributed to inherent limitations in the methods applied in these studies to measure UDS. First, different agents have been used to induce UDS, resulting in the estimation of the capacity of different repair mechanisms. Further, in some of these studies, agents used to induce UDS require metabolization before interaction with DNA is possible. Therefore, interindividual differences in metabolization of carcinogens to electrophylic intermediates and consequently initial formation of DNA damage may actually determine the extent of observed repair. Moreover, in most of these studies, hydroxyurea is used as agent to block semiconservative DNA replication, which may also influence DNA repair itself. Also, differences in both cellular uptake of radiolabeled nucleotide precursors, used to visualize repair synthesis, and duration of exposure to carcinogen or nucleotide precursor, may explain part of the discrepancies observed between these studies.

Little is known regarding the effects of nutrition on DNA repair. As will be elucidated in detail below, the activity of the nicotinamide adenine dinucleotide $\left(\mathrm{NAD}^{+}\right)$-dependent DNA-repair-related enzyme poly(ADP-ribose) polymerase (NAD+ ADP-ribosyltransferase, EC 2.4.2.30; PADPRT), may be subject to modulation by alterations in dietary niacin intake (65).

\subsection{Poly(ADP-ribosylation) and niacin metabolism}

\subsubsection{Poly(ADP-ribosylation). The enzymatic process}

In 1963, Chambon, Weill and Mandel (66) observed that nicotinamide mononucleotide stimulated the incorporation of ATP into acid-insoluble fractions of chicken liver nuclei and the product of their reaction was identified as poly(ADP-ribose). Their report was in fact the first indication for activity of the enzyme poly(ADP-ribose) polymerase $\left(\mathrm{NAD}^{+} \mathrm{ADP}\right.$-ribosyltransferase, $\mathrm{EC}$ 2.4.2.30).

Poly(ADP-ribosylation) (PADPR) is a post-transcriptional process, capable of modifying several nuclear proteins, at least in vitro. Examples are linker and core histones (67-73), Ligase I (74) and ligase II (75), DNA polymerase $\alpha$ and DNA 


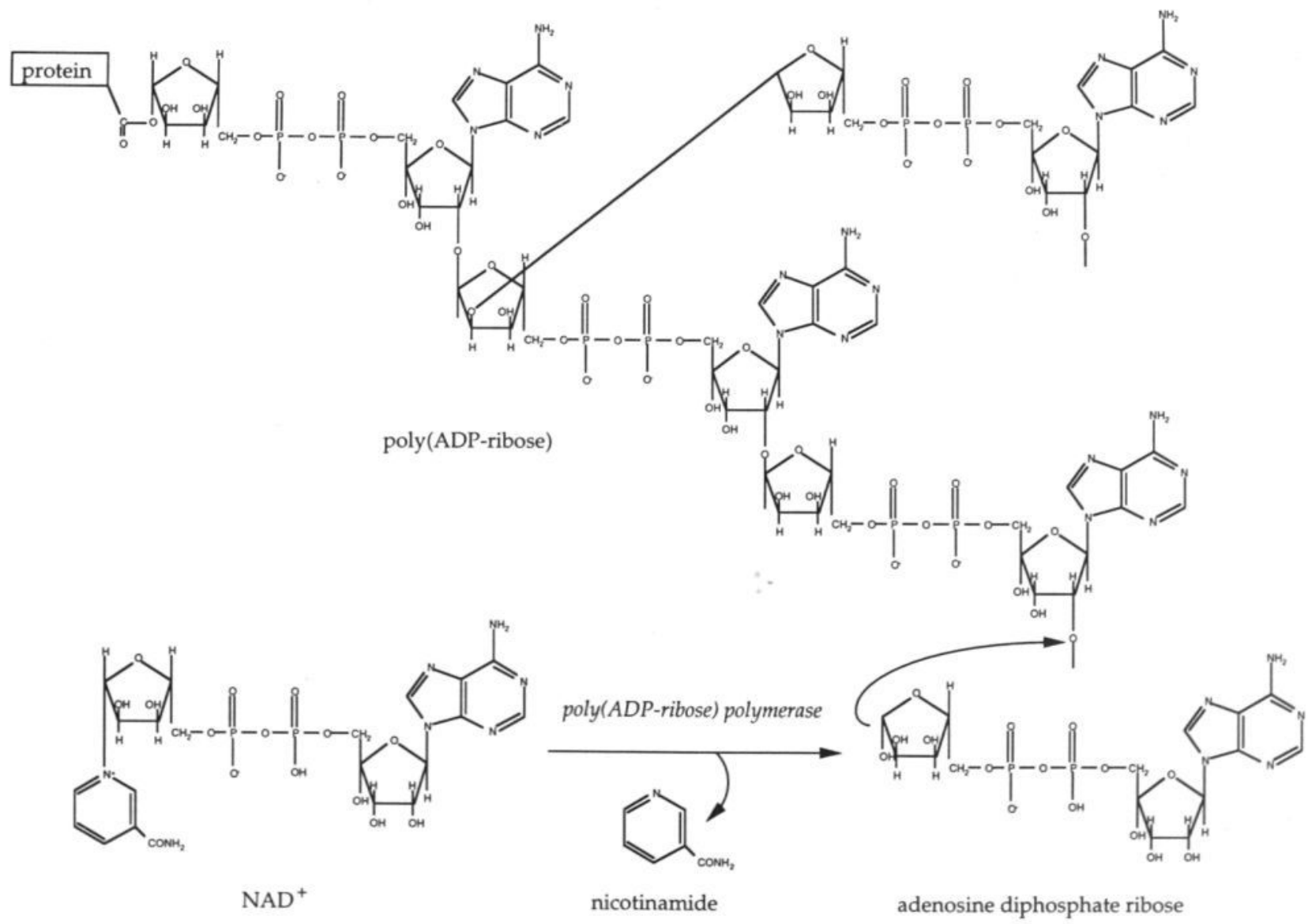


polymerase $\beta$ (74), topoisomerase I $(76,77)$ an topoisomerase II $(78)$, acetylated histones (79), HMG proteins (80) nuclear matrix proteins $(81,82)$, and interestingly, the PADPRT itself (83-85). The active PADPRT gene is located on chromosome 1, and additional regions with sequence homology have been identified on chromosomes 13 and $14(86,87)$. The enzyme contains three functional domains: a $46 \mathrm{kDa}$ aminoterminal DNA-binding domain containing two zinc-binding fingers; a central $22 \mathrm{kDa}$ domain, containing automodification sites and a carboxyterminal fragment of $54 \mathrm{kDa}$ containing the $\mathrm{NAD}^{+}$-binding site.

In response to DNA single or double strand breaks, the enzyme associates with DNA and catalyzes rapid transfer of the adenosine diphoshate ribose (ADPribose) moieties of intracellular nicotinamide adenine dinucleotide $\left(\mathrm{NAD}^{+}\right)$by hydrolysis of the $\mathrm{N}$-glycosylic bond between nicotinamide and the ribose grouptowards linear and branched (88) protein-bound poly(ADP-ribose) polymers (Figure 1.2). The poly(ADP-ribose) polymer has a half-life as short as 1 minute due to the activity of poly(ADP-ribose) glycohydrolase (89). This enzyme degrades the polymer into ADP-ribose monomers. The last protein-bound ADP-ribose monomer is removed by the enzyme ADP-ribosyl protein lyase (90). Besides its potential roles in DNA repair and carcinogenesis, PADPR has been suggested to be involved in proliferation and differentiation (reviewed in 91). However, while this Thesis was in preparation, Wang et al. (276) showed that mice carrying homozygous germ-line mutations within the PADPRT gene are healthy and develop normally. These data suggest that PADPRT or PADPR are not required for proliferation and differentation during normal development in vivo.

\subsubsection{Poly(ADP-ribosylation). Induction by DNA strand break-inducing agents}

There are several indications that PADPR plays a crucial role in cellular responses to DNA damage. Numerous studies indicate that treatment of mammalian cells with various DNA damaging agents causes rapid formation of poly(ADP-ribose) polymers and reduces intracellular NAD+ levels. Examples are MNNG-treated rat hepatocytes (92), human keratinocytes (70), C3H10T1/2 cells $(93,94)$ and PBLs (95); MNU-treated mouse leukemia cells (96); $\gamma$-ray-treated mouse leukemia cells (96); UV-treated rat hepatocytes (92), human fibroblasts (97) and PBLs (95); active oxygen species-treated human keratinocytes (70), C3H10T1/2-cells (98); hydrogen peroxide-treated PBLs $(99,100)$, murine macrophages (101), porcine endothelial cells and human fibroblasts (102); cumene hydroperoxide-treated PBLs (103); calicheamicin $\gamma 1$-treated human HL60 cells (104), tumor promotor-treated human lymphocytes (105); cisplatin-treated rat ovarian tumor cells and monkey cells (106) and hyperthermia-treated C3H10T1/2 cells $(107,108)$. Thus, a common feature of agents that may cause either directly or indirectly, via enzymatic incision at a DNA lesion by other repair enzymes, DNA strand breakage is the induction of PADPR. In addition, 
the absolute necessity for DNA strand breaks to activate PADPRT is confirmed by observations that DNAse I treatment of permeabilized mammalian cells resulted in poly(ADP-ribose) polymer formation $(92,107)$. Also, only DNA containing single or double strand breaks activates PADPRT in vitro (109).

\subsubsection{Poly(ADP-ribosylation). Proposed functions with regard to cellular responses to DNA damage}

At least four mechanisms have been proposed with regard to the role of PADPR in cellular recovery from DNA damage (Figure 1.3).

One of the first models was proposed by Creissen and Shall (110), who suggested that PADPR stimulates the activity of ligase II in rodent cells in response to alkylation damage, and thus may facilitate the final step in BER. In line, intracellular $\mathrm{NAD}^{+}$-depletion and PADPRT inhibition caused enhanced strand break accumulation in DMS-treated mouse leukemia cells (111) and decreased $X$-ray or $\gamma$-ray-induced single strand break resealing (112). However, later reports do not support the idea that stimulation of ligase activity is the main function of PADPR during DNA repair $(74,113)$. Besides ligase, PADPR may influence the activity of other enzymes (114).

Secondly, PADPR of histones may influence chromatin structure, thereby increasing the accessibility of damaged DNA for other repair enzymes. Althaus et al. $(71,115)$ and Boulikas (91) suggested that PADPR may serve to shuttle histones off and onto DNA. In this model, PADPRT interacts with DNA-nucleosome complexes. In presence of $\mathrm{NAD}^{+}$, DNA-bound PADPRT automodifies itself with numerous branched (ADP-ribose) polymers and dissociates from DNA. Since histones have a higher affinity for poly(ADP-ribose) polymers in comparison to DNA (116), PADPRT-bound polymers would attract core and linker histones from the DNA, leaving the DNA more accessible to other repair enzymes. Subsequent degradation of the polymer by the poly(ADP-ribose) glycohydrolase decreases the number of polymer-binding sites for histones, allowing reassociation of histones with DNA. In addition to the unfolding of individual nucleosomes, formation of poly(ADP-ribose) polymers on histone $\mathrm{H} 1$ and degradation by poly(ADP-glycohydrolase) may serve the temporarily deconsensation and subsequent recondensation, respectively, of higher order chromatin structures (histone H1-nucleosome interactions) (117-119).

According to the most recent and probably most attractive mechanism proposed, the DNA binding domain of the PADPRT may temporarily shield DNA breaks until other repair enzymes are present at the damaged site. Upon automodification by the catalytic domain, the enzyme dissociates from the DNA, allowing access of the damaged site to other repair enzymes. Such a temporal DNA-break protection mechanism would prevent recombination or, alternatively spurious DNA replication by transiently blocking the progress of 

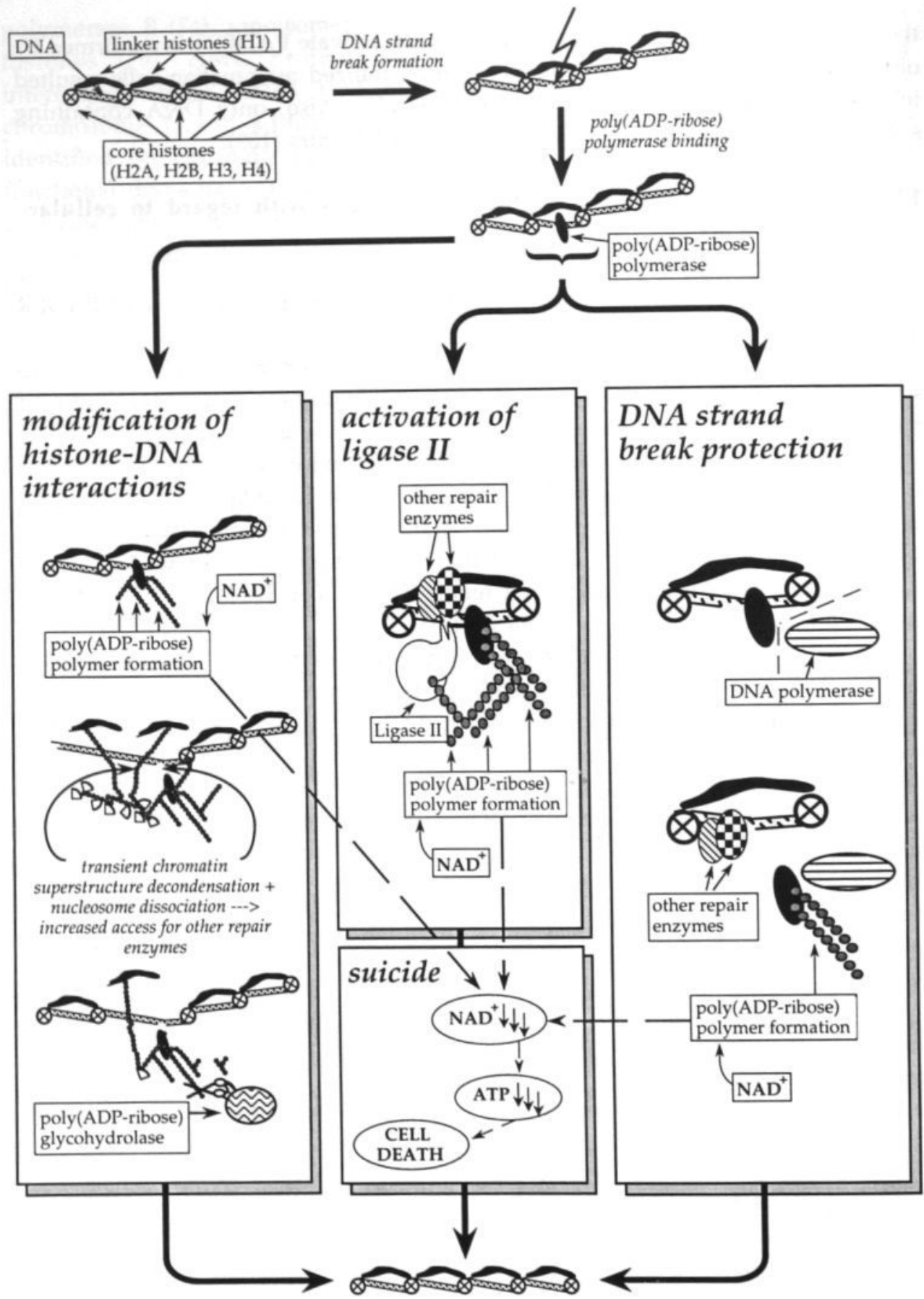

Figure 1.3. Proposed roles of poly(adenosine diphosphate ribosylation) in DNA repair. 
DNA polymerases along replication forks, near damaged sites. This would ultimately result in a cell cycle delay, thereby increasing time for adequate DNA repair before DNA replication takes place. In addition, the DNA break-associated PADPRT or synthesis of poly(ADP-ribose) polymers may represent an early general cellular warning signal that DNA has been damaged. Interestingly, this DNA break protection mechanism is proposed to be only associated with BER, but not with NER $(13,14,85,120,121)$.

Finally, PADPR may represent itself a cellular suicide mechanism (114) or contribute to programmed cell death (apoptosis). This would reduce the possibility that heavily damaged cells undergo DNA replication and division. In response to DNA strand breaks, reduced levels of intracellular $\mathrm{NAD}^{+}$may interfere with glycolysis and ATP formation and thereby contribute to loss of cell viability. Several studies report associations between DNA strand break formation, induction of PADPR and $\mathrm{NAD}^{+}$depletion, ATP depletion, release of lactate dehydrogenase and cell lysis, when mammalian cells are exposed to oxidants or alkylating agents $(101,102,122,123)$. In addition, it has been recently proposed that PADPR is required for stress-induced apoptosis in human cells (124).

\subsubsection{Poly(ADP-ribosylation). Relation to carcinogenesis}

When cultured mammalian normal or transformed cells are treated with DNA damaging agents in combination with PADPRT inhibitors, both potentiation and reduction of the mutagenic or transforming effect, in comparison to the effects caused by carcinogen exposure alone, have been observed. Similarly, PADPRT inhibitors both potentiated and reduced the carcinogenicity of DNA damaging compounds in rodents in vivo (reviewed in 91). It is likely that part of these variations may be explained by studied cell type or animal organ, proliferation and differentiation state of the cells, stage of the cell cycle, genetic loci studied and type and concentration of DNA damaging agents and PADPRT inhibitors used (89). However, a mechanistic explanation for these discrepancies may be the following. First, inhibition of PADPR may prevent cellular suicide to occur in normal cells and thereby cause elevated accumulation of DNA damage and increased mutation frequencies in these cells. Alternatively, inhibition of PADPR and repair of lesions induced by DNA damaging agents in highly proliferating transformed cells may cause preferential killing over normal cells.

In a few studies in humans, attempts have been made to relate the extent of basal or carcinogen-induced lymphocytic PADPRT activities, measured in PBLs or surgically removed cancer specimens, with (the stage of) various cancers. Both increased $(73,105)$ and decreased $(99,103)$ basal or induced PADPRT activity has been reported, in patients with several cancers. Moreover, a homozygous germline deletion in a sequence located on chromosome 13, with homology to the 
PADPRT gene, was frequently found in DNA obtained from various human tumors, suggesting that loss of this particular sequence may predispose individuals to malignancy (125). However, this deletion was not associated with alterations in parameters related to poly(ADP-ribosylation). Applying the in vivo model of Teebor and Becker (126) for N-AAF-induced hepatocarcinogenesis in rats, Cesarone et al. (127) initially observed a decrease in amount of hepatic PADPRT and enzyme activity, while, with increased risk for hepatocarcinogenesis, both amount and activity of the enzyme returned to levels before treatment. Using the same model, Kiehlbauch et al. (128) found, with increased cancer risk, both decreased hepatic poly(ADP-ribose) polymer levels in vivo and increased basal PADPRT activity measured in isolated hepatocytes. Thus, despite the proposed role of PADPR in modulation of DNA repair, a potential negative relation between PADPR and carcinogenesis has not been demonstrated, at present.

\subsubsection{Niacin metabolism}

Nicotinamide adenine dinucleotide, the pyridine nucleotide required for PADPR, can be synthesized from three precursors. Among these are nicotinic acid and nicotinamide, both of which have been referred to as niacin (reviewed in 129). Niacin actually is the general description for pyridine 3-carboxylic acid and derivatives with the qualitative biological activity of nicotinic acid (130). In humans and other mammalians, nicotinic acid is readily absorbed in the stomach and small intestine (131) and may be enzymatically converted to nicotinic acid mononucleotide by the nicotinic acid phosphoribosyltransferase. This intermediate subsequently acquires an adenylic acid group from ATP in a reaction catalyzed by the nicotinic acid mononucleotide adenylyltransferase to form nicotinic acid adenine dinucleotide. Then, NAD synthase transfers an amide group from glutamine to nicotinic acid adenine dinucleotide, thereby completing $\mathrm{NAD}^{+}$synthesis (Preiss-Handler Pathway). Nicotinamide, the other niacin $\mathrm{NAD}^{+}$-precursor, can be metabolized by the nicotinamide phosphoribosyltransferase to nicotinamide mononucleotide, which is converted to $\mathrm{NAD}^{+}$by the nicotinamide mononucleotide adenyltransferase (Dietrich Pathway) (131-136). Under physiological conditions in vivo, the direct conversion of nicotinamide into nicotinic acid by a nicotinamidase, found in homogenates of various mammalian tissues, is unlikely $(130,131)$. Tryptophan is the third precursor for $\mathrm{NAD}^{+}$, which can be converted via the kynurenine pathway to quinolinic acid. In turn, quinolinic acid can be converted to nicotinic acid mononucleotide, which can be further metabolized to $\mathrm{NAD}^{+}$via the PreissHandler Pathway. In fact, in humans, $60 \mathrm{mg}$ of tryptophan can provide $1 \mathrm{mg}$ of niacin equivalents (129). In humans, nicotinamide can be methylated by nicotinamide methyltransferase towards N1-methylnicotinamide, which is excreted in urine or alternatively further metabolized by the N1- 
methylnicotinamide oxidases to secondary excretion products N1-methyl-4pyridone-3-carboxamide and N1-methyl-2-pyridone-5-carboxamide (137-139). Other human urinary excretion products of nicotinamide and nicotinic acid include nicotinamide $\mathrm{N}^{1}$-oxide, nicotinuric acid, nicotinamide and nicotinic acid (131). A detailed scheme of niacin metabolism is presented in Chapter 4, Figure 4.5 .

\subsubsection{Niacin metabolism. Importance with regard to modulation of poly(ADP- ribosylation), DNA repair and cancer risk}

As discussed in previous paragraphs, PADPR is believed to be required for efficient DNA repair or alternatively, for preferential killing of cells in which the number of premutagenic lesions is undesirable high. Moreover, since at least some studies have shown negative associations between PADPR and cancer risk in humans and rodents $(99,103,125,128)$, it can be hypothesized that an increase in intracellular levels of precursors of $\mathrm{NAD}^{+}$may contribute to improved DNA repair and ultimately to decreased cancer risk. Treatment of isolated human and rodent cells with millimolar concentrations of nicotinamide indeed enhances the activity of DNA repair, triggered by simultaneous treatment with UV, alkylating agents, EO or $\gamma$-rays $(95,140-146)$. However, since nicotinamide, next to being a precursor for $\mathrm{NAD}^{+}$, also directly inhibits PADPRT $(94,95,147)$, interpretation of these results, solely with regard to the former function of nicotinamide, is complicated.

A limited number of studies have reported effects of ex vivo and in vivo nicotinic acid supplementation on DNA repair in mammalian cells ex vivo treated with carcinogens. Berger and Sikorski (140) observed no potentiation of DNA repair synthesis, induced by alkylating agents, when PBLs were simultaneously treated with nicotinic acid. In contrast, Weitberg and Corvese (148) observed a reduction in number of single strand breaks, induced in lymphocytes and human leukemia cells by agents that interfere with adenosine metabolism, when cells were pre-exposed to nicotinic acid. Further, supplementation of two humans with nicotinic acid during several weeks resulted in enhanced peripheral blood lymphocytic $\mathrm{NAD}^{+}$-levels and in reduced number of single strand breaks, induced by oxygen radicals in PBLs ex vivo (149).

In a few studies, the effects of in vivo niacin depletion in rats, by giving diets with no or reduced tryptophan and nicotinic acid contents, on NAD+-levels, PADPR and DNA damage and repair have been investigated. Zhang et al. (150) reported reduced blood, liver and muscle $\mathrm{NAD}^{+}$-levels in niacin-deficient rats, together with an increased number of ex vivo oxygen radical-induced lymphocytic and hepatocytic DNA single strand breaks. They further observed both increased and decreased ex vivo oxygen radical-induced PADPRT activity, 
at different stages of niacin deficiency. Rawling et al. (151) reported reduced $\mathrm{NAD}^{+}$-levels in several organs of niacin deficient rats and decreased basal hepatic poly(ADP-ribose) polymer levels.

It is known that niacin depletion during several weeks, achieved by tryptophan and nicotinic acid deficient diets, in male humans results in reduced erythrocytic NAD+-levels (152) and decreased levels of plasma and urinary N1methylnicotinamide (153). These levels turned to basal levels, as determined before depletion, when niacin was repleted. At present however, no studies with an integrated approach have been reported in humans in vivo, with regard to the effects of altered niacin intake on niacin status, PADPRT activity, DNA repair activity and persistence of DNA damage.

\subsection{The adaptive response}

\subsubsection{The adaptive response. A phenomenon reflecting the ex vivo induction of DNA repair mechanisms}

In 1977, Samson and Cairns showed that pre-treatment of $E$. coli with low levels of MNNG resulted in protection against cytotoxic and mutagenic effects, induced by high levels of MNNG (154). They proposed that pre-treatment resulted in induction of a DNA repair system, requiring de novo protein synthesis. The process was termed the adaptive response (AR). Later, it was shown that the AR involved the induction of several gene products. An example is the ada gene product mentioned before, capable of removing $\mathrm{O}^{6}$-methylguanine.

In 1984, Olivieri et al. (155) observed a comparable phenomenon in isolated PBLs. They demonstrated that the number of chromosome aberrations was reduced when human lymphocytes were pre-treated with low levels of radioactive thymidine followed later by a challenge of $\mathrm{X}$-rays, in comparison to the number of chromosome aberrations induced by X-ray exposure alone. They proposed that the AR to IR involved the induction of a chromosomal repair mechanism. Several investigators have confirmed the existence of an inducible AR to IR in PBLs. In addition, AR-like phenomena have been observed for damage induced by other agents. In the past ten years, the AR to IR and other compounds has been characterized in more detail. Table 1.1 summarizes current available literature data on the AR in PBLs. The main conclusions that can be drawn from these studies are the following: The AR to IR is not induced when cells are pre-treated during G0, instead, pre-treatment during G1 is necessary to elicit the AR. Thus, the induction of the AR requires cell proliferation. Synthesis of proteins is necessary for expression of the AR, while the phenomenon is not related to diffusible inter-cellular factors. Once induced, the AR persists for at least three cells cycles, suggesting that induced repair proteins can be transferred to daughter cells. Further, a minimum period of time is required between pre- 
Table 1.1. Literature data on the adaptive response in human peripheral blood lymphocytes.

\begin{tabular}{|c|c|c|c|c|c|c|c|}
\hline \multicolumn{2}{|c|}{ pre-treatment } & \multicolumn{2}{|c|}{ challenge } & \multirow[t]{2}{*}{ endpoint } & \multirow{2}{*}{\multicolumn{2}{|c|}{$\begin{array}{l}\text { observation } \\
\text { with regard to } \\
\text { effect of } \\
\text { pre-treatment } \\
\text { on endpoint }\end{array}$}} & \multirow[t]{2}{*}{ reference } \\
\hline dose & agent & dose & agent & & & & \\
\hline
\end{tabular}

$0.01-0.1 \mu \mathrm{Ci} / \mathrm{ml} \quad$ TT

\section{$5-50 \mathrm{ng} / \mathrm{ml}$,}

repeated

$0.5 \mathrm{nCi}-1.0 \mu \mathrm{Ci} / \mathrm{ml}$

TT

MNNG

$1 \mathrm{CGy}$

X-rays

$1.5 \mathrm{~Gy}$

$1.5 \mathrm{~Gy}$

$1.5 \mathrm{~Gy}$

$0.01-0.1 \mu \mathrm{Ci} / \mathrm{ml}$

TT

X-rays or

1 cGy or

$0.1 \mu \mathrm{Ci} / \mathrm{ml}$

1 cGy

$0.1 \mu \mathrm{Ci} / \mathrm{ml}$

$0.01 \mu \mathrm{Ci} / \mathrm{ml}$

$1 \mathrm{cGy}$

$1.5 \mathrm{~Gy}$

$1.5 \mu \mathrm{M}$

X-rays

TT

TT

X-rays
$0.3 ; 0.4 ; 1.5 \mathrm{~Gy}$

2-4 $\mu \mathrm{g} / \mathrm{ml}$

75-150 $\mu \mathrm{M}$

X-rays

CA

MNNG

MMC

ENU

X-rays

CA

X-rays

CA

X-rays

CA

X-rays

CA

$1 \mu \mathrm{Ci} / \mathrm{ml}$

$2.5 \mu \mathrm{g} / \mathrm{ml}$

$0.36 \mathrm{mM}$
$1.5 \mathrm{~Gy}$

$1.5 \mathrm{~Gy}$

$0.75 \mathrm{~Gy}$

$0.75 \mathrm{~Gy}$ reduction

reduction

no effect

no effect

reduction

reduction

reduction

redūction

reduction

reduction

reduction

elevation

no effect

no effect

reduction or

synergism
AR not related to cell-stage sensitivity or delay in cell-cycle

AR dependent on PT dose;

interindividual differences;

no cross-reactivity

3-aminobenzamide inhibits $A R$ :

AR not related to diffusible factors;

AR not an artefact of cell-cycle

related differential sensitivity

AR absent in G0 PBLs, but

persistent for at least 3 cell-cycles

in proliferating PBLs;

AR dependent on time-

interval between PT and C

no $A R$ when PT > 20 cGy;

3-aminobenzamide inhibits $A R$

culturing cells in absence of

nicotinamide prevents AR

in whole blood cultures and

isolated PBLs

radiation induced $A R$ is

different from AR induced

by alkylating agents

persistent absence of AR

in PBLs from 2 donors

4/18 donors showed no $A R$;

in some cases synergism;

persistent absence of AR in

2 donors 
$\omega$ Table 1.1. continued

\begin{tabular}{|c|c|c|c|c|c|c|c|}
\hline \multicolumn{2}{|c|}{ pre-treatment } & \multicolumn{2}{|c|}{ challenge } & \multirow[t]{2}{*}{ endpoint } & \multirow{2}{*}{$\begin{array}{l}\text { observation } \\
\text { with regard to } \\
\text { effect of } \\
\text { pre-treatment } \\
\text { on endpoint }\end{array}$} & \multirow[t]{2}{*}{ comments } & \multirow[t]{2}{*}{ reference } \\
\hline dose & agent & dose & agent & & & & \\
\hline
\end{tabular}

$0.01 \mu \mathrm{Ci} / \mathrm{m}$

$0.01 \mu \mathrm{Ci} / \mathrm{ml}$

$0.1 \mu \mathrm{Ci} / \mathrm{ml}$

TT

$0.5 \mathrm{~Gy}$

X-rays

$0.5 \mathrm{~Gy}$

$X$-rays

$X$-rays

$0.5 \mathrm{~Gy}$

$5 \mu \mathrm{Ci} / \mathrm{ml}$

32P

HTO

$0.5 \mathrm{~Gy}$

5 cGy

X-rays

X-rays

X-rays

1-5 cGy

$X$-rays

$1.5 \mathrm{~Gy}$

X-rays

interindividual differences

reduction

reduction

in $\mathrm{AR}$

(259)

reduction

reduction

reduction

$1 \mathrm{cGy} ; 0.5 \mathrm{~Gy}$, at

X-rays

$1.5 \mathrm{~Gy}$

X-rays

no effect

absence of AR in PBLs from

3 donors

reduction

AR dependent on both dose

$0.01-0.1 \mu \mathrm{g} / \mathrm{ml}$

BLM

$0.01-0.1 \mu \mathrm{g} / \mathrm{ml}$

$1.5 \mu \mathrm{g} / \mathrm{ml}$

BLM

X-rays

reduction

reduction

and dose-rate of PT

$0.01-0.1 \mu \mathrm{g} / \mathrm{ml}$

BLM

$1.5 \mu \mathrm{g} / \mathrm{ml}$

BLM

CA

reduction

reduction

1 cGy

BLM

$1.5 \mathrm{~Gy}$

X-rays

reduction

reduction

X-rays

$1.5 \mathrm{~Gy}$
$1.5 \mathrm{~Gy}$

25-250 $\mu \mathrm{M}$ repeatedly

$\mathrm{H}_{2} \mathrm{O}_{2}$

$1 \mathrm{cGy}$ or

$2 \times 1$ CGy

1 cGy

$1 \mathrm{~Gy}$

$X$-rays

X-rays

no effect

reduction

reduction

X-rays

$M$

reduction

3-aminobenzamide inhibits AR

(169)

cycloheximide inhibits AR

repeated PT did not enhance

AR, observed after single PT

AR absent in G0 PBLs;

$A R$ dependent on time-

interval between PT and C;

interindividual differences

$\begin{array}{llllll}2 \mathrm{cGy} & \text { X-rays } & 15-16 \mathrm{CGy} & \text { radon } & \mathrm{CA} & \text { reduction } \\ 2 \mathrm{CGy} & \text { X-rays } & 1.5 \mathrm{~Gy} & \text { X-rays } & \mathrm{CA} & \text { no effect } \\ 10-75 \mathrm{mGy} & \text { X-rays } & 0.75-1.5 \mathrm{~Gy} & \text { X-rays } & \mathrm{CA} & \text { reduction } \\ 41^{\circ} \mathrm{C}-43^{\circ} \mathrm{C} & \mathrm{HT} & 0.75-1.5 \mathrm{~Gy} & \text { X-rays } & \mathrm{CA} & \text { reduction }\end{array}$

duced AR: cycloheximide

inhibits $A R ; A R$ not related to diffusible factors 
Table 1.1. continued

\begin{tabular}{|c|c|c|c|c|c|c|c|}
\hline \multicolumn{2}{|c|}{ pre-treatment } & \multicolumn{2}{|l|}{ challenge } & \multirow[t]{2}{*}{ endpoint } & \multirow{2}{*}{$\begin{array}{l}\text { observation } \\
\text { with regard to } \\
\text { effect of } \\
\text { pre-treatment } \\
\text { on endpoint }\end{array}$} & \multirow[t]{2}{*}{ comments } & \multirow[t]{2}{*}{ reference } \\
\hline dose & agent & dose & agent & & & & \\
\hline 1 CGy-2 cGy & X-rays & $0.5-1.5 \mathrm{~Gy}$ & X-rays & $\mathrm{CA}$ & $\begin{array}{l}\text { no effect } \\
\text { or synergism }\end{array}$ & $\begin{array}{l}\text { absence of AR in PBLs from } \\
2 \text { donors, throughout the } \\
\text { cell-cycle. }\end{array}$ & (271) \\
\hline 10 cGy & X-rays & $1.5 \mathrm{~Gy}$ & X-rays & $\mathrm{CA}$ & reduction & PBLs from 3 donors & (272) \\
\hline $25-250 \mu \mathrm{M}$ & $\mathrm{H}_{2} \mathrm{O}_{2}$ & $1.5-3 \mathrm{~Gy}$ & $\mathrm{X}$-rays & $\mathrm{MN}$ & reduction & $\begin{array}{l}\text { AR persistent in cells in } \\
\text { differential cell-stage; } \\
\text { interindividual differences }\end{array}$ & (273) \\
\hline $5 c G y$ & X-rays & $100 \mathrm{cGy}$ & X-rays & $\begin{array}{l}\text { CA } \\
\text { cell survival }\end{array}$ & $\begin{array}{l}\text { reduction } \\
\text { increase }\end{array}$ & $\begin{array}{l}\text { increase in cell survival } \\
\text { not only explainable by } \\
\text { decrease in singly } \\
\text { aberrant cells } \rightarrow \text { AR acts on } \\
\text { lethal damage in non- } \\
\text { aberrant cells. }\end{array}$ & (274) \\
\hline 2 cGy & X-rays & $15-16 c G y$ & radon & $\mathrm{CA}$ & reduction & & (17) \\
\hline $5-20 \mathrm{ng}$ & $\mathrm{MMC}$ & $200 ; 400 \mathrm{ng} / \mathrm{ml}$ & $\mathrm{MMC}$ & SCE & reduction & & (275) \\
\hline
\end{tabular}

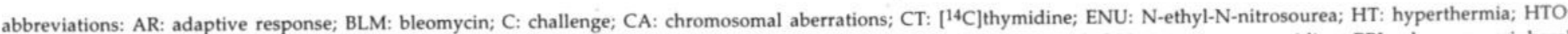

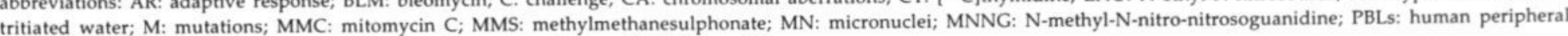
blood lymphocytes; PT: pre-treatment; SCE: sister chromatid exchanges; TT: $\left[{ }^{3} \mathrm{H}\right]$ thymidine. 
exposure and challenge, to allow expression of the AR. Moreover, the extent of adaptation is influenced by the concentration of the agent or radiation-dose and dose-rate applied during pre-exposure. Not surprisingly, pre-treatment with radiomimetic agents that cause single strand scission can also induce an AR to IR. In addition, pre-treatment with hydrogen peroxide induces an AR to IR indicating that the induced repair mechanism(s) likely act(s) on IR-induced oxydative damage. Moreover, interindividual differences exist in the extent of AR to IR. In PBLs obtained from some individuals no adaptation has been observed at all. These data suggest that some individuals may be genetically predisposed for the AR to IR. Further, the AR to IR is not only observed with regard to chromosome aberrations, but also related to prevention of mutagenesis, micronuclei formation and non-lethal damage, undetectable by chromosome aberrations-analysis. Therefore, the AR may involve the induction of different repair mechanisms. Furthermore, pre-exposure to low levels of alkylating and cross-linking agents can induce an AR to chromosomal damage induced by the same agent. However, the AR induced by low IR pre-exposure does not act on damage, induced by these agents. Thus, pre-exposure to alkylating agents or to IR does not likely induce the same repair mechanism(s) (for references see Table 1.1).

Besides in human PBLs, the AR to IR and alkylating agents has been demonstrated in other human and mammalian cells (156-164). Further, in rodents, the AR to IR and alkylating agents has been induced in vivo $(165,166)$. At present, it is unknown whether similar adaptive mechanisms with regard to DNA repair may occur in human populations in vivo chronically exposed to low doses of environmental carcinogens, like PAH.

\subsubsection{Possible involvement of poly(ADP-ribose) polymerase in the adaptive response to ionizing radiation}

Little is known with regard to the nature of repair mechanism(s) that may be induced by pre-exposure to low doses of IR. When PADPRT inhibitors like 3aminobenzamide were added to pre-exposed PBLs after challenge with X-rays, the AR to IR was no longer observable (167-169). Further, when PBLs were grown in absence of nicotinamide, one of the precursors for NAD ${ }^{+}$in PBLs (132), the AR to IR was found to be absent (170). Therefore, there is indirect evidence that the AR may involve the induction of PADPRT, thus a chromosomal repair mechanism.

\subsection{DNA damage and p53 accumulation}

\subsubsection{A role for wild-type p53 tumour suppressor protein in modulating the persistence of DNA damage}


In 1979, Lane and Crawford identified the p53 protein as part of a complex with Large T antigen in SV-40 transformed cells (171). Later, several lines of evidence have led to the assumption that $p 53$ is a tumour suppressor gene. First, about $60 \%$ of all human cancers have mutations within the p53 gene. In most cases, these genetic alterations consist of missense mutations, with loss of heterozygosity -which is a hallmark of tumour suppressor genes- thus resulting in loss of normal functional p53 protein (5). Further, individuals with LiFraumeni syndrome (172), having inborn defects in one of the $p 53$ alleles, are pre-disposed to cancer. It is evident that genetic alterations in the other allele can readily result in loss of heterozygosity and thus in loss of functional p53. Also, mice with absent or mutant p53 develop tumours with greater frequency than normal mice (173).

The first demonstration that p53 was actually involved in the cellular response to DNA damage was published by Maltzman and Czyzyk in 1984. They observed that treatment of non-transformed mouse cells with UV resulted in an increase in p53 levels $(174)$, which was confirmed by others $(175,176)$. Other DNA damaging agents can cause p53 accumulation in mammalian cells as well. Examples are $\gamma$-rays (177-179), bleomycin and actinomycin D (180), NQO (174), MMS (181), mitomycin C, cisplatin and nucleotide analogues $(182,183)$. The accumulation of p53 after DNA damage is not related to increased mRNA expression, but instead to a combination of increased protein stability and ongoing translation $(177,182)$.

Two functions have been proposed for p53 accumulation after DNA damage (184): induction of apoptosis and induction of pathway(s) that arrests cells in G1 phase of the cell cycle. Indeed, it has been demonstrated that p53 is required for induction of apoptosis after treatment of mammalian cells with IR or DNA damaging agents (185-187). Thus, by starting up a program of physiological cell death, damaged cells, which could be initiated upon DNA replication and subsequent cell division, are preferentially removed. When cells are exposed to a variety of DNA damaging agents, arrest often occurs in both the G1 and G2-phase of the cell cycle. This would provide additional time for efficient DNA repair prior to initiation of replicative DNA synthesis or onset of mitosis, thus ultimately decreasing the chance on malignant cells. Several lines of evidence indicate that p53 mediate(s) (a) G1 cell cycle checkpoint pathway(s). When wildtype p53 is reintroduced into transformed cells with absent functional p53, growth arrest is achieved with apparant accumulation of cells in G1 phase. Further, mammalian cells with no or mutant p53 fail to undergo G1 arrest after $\gamma$-irradiation $(177,188)$, while transfection of wild-type p53 genes into these cells restores the G1 arrest (188). Moreover, introduction of mutant p53 genes in normal cells has been found to prevent this G1 arrest (188). In addition, cells expressing human papilomavirus E6 oncogene product which is known to interfere with normal p53 function, continue cell cycle progression after 
actinomycin D or UV treatment (189-191).

The mechanisms of p53-mediated G1 arrest and apoptosis after DNA damage are not known in full detail. Wild-type p53 protein is a sequence-specific DNA binding protein capable of binding to and regulating transcription of other genes, containing p53 responsive elements (192-195). In response to DNA damage, p53 binds to p53 responsive elements (196) and can induce transcription of at least three down-stream effector genes: Gadd45 (179,197,198), Mdm2 (199-202) and WAF1/CIP1 $(178,203)$.

The Gadd45 gene (for Growth arrest and DNA damage inducible), was induced in a strictly p53-dependent manner after treatment of cells with IR $(179,197)$, while treatment by UV and MMS resulted in p53-independent Gadd45 induction $(190,198)$. This illustrates the complexity of these pathways and suggests the existence of at least two different mechanisms of Gadd45 induction and G1 arrest, depending on type of DNA damage induced. In addition, gene products, absent in the disease Ataxia-Telangiectasia (AT) (so called AT products), were presumed to be necessary for IR-induced p53 accumulation, Gadd 45 mRNA expression and G1 arrest $(181,197)$. Very recently, Savitsky et al. (253) have identified a gene called ATM, which is mutated in AT. Part of this gene was found to encoded for a product with similarity to phosphatidylinositol-3'kinases. These enzymes are known to be involved in mitogenic signal transduction and, important in this respect, in cell cycle control. Induction of p53 accumulation also depends on AT products, when cells are exposed to MMS and bleomycin, but not when exposed to UV (181). The strict requirement for Gadd45 gene product in either radiation induced cell cycle arrest or cell death has not been directly demonstrated yet.

The $21^{\mathrm{WAF} 1 / \mathrm{CIP} 1}$ protein was simultaneously discovered as a $21 \mathrm{kDa}$ protein product, originating from a sequence transcriptionally activated by p53 (WAF1: wild-type p53 activated fragment $\underline{1}$ ), and as a potent inhibitor of cyclindependent kinases (cdk) (CIP1: çdk-interacting protein) $(203,204)$. Cdk are believed to be required for G1 to S-phase transition, probably in association with the retinoblastoma gene product (205). Thus, the following model has been proposed (206): Upon DNA damage, in particular DNA strand breaks, AT-gene products mediate p53 accumulation, which in turn results in upregulation of transcription of WAF1/CIP1. Finally, the $21 \mathrm{kDa}$ protein associates with cdkcyclin complexes, thereby inhibiting the onset of replicative synthesis. Recent observations support the role of this pathway in both cell cycle inhibition and induction of apoptosis $(178,181)$.

The $m d m 2$ gene is proposed to act as a negative feedback regulator of p53 activity (207-209). $m d m 2$ may limit the strength of p53 induced G1 arrest after IR, by possibly inhibiting p53-mediated transcription of gadd45 (201).

In contrast to effects of p53 protein on downstream effector genes and cell cycle progression, less is known with regard to mechanism(s) acting between initial (recognition of) DNA damage and increase in p53 accumulation. As mentioned 
gene product(s), absent in AT, are believed to be required prior to p53 accumulation after IR. Nelson and Kastan (180) showed that, under conditions of inhibited replicational DNA synthesis, UV treatment of NER-deficient XPA lymphoblasts did not induce p53 accumulation, in comparison to normal lymphoblasts. Treatment of these repair-deficient cells with X-rays resulted in p53 accumulation to a similar extent as found in normal cells. These data suggest that functional NER, and thus enzymatic strand scission, is required for induction of p53 accumulation by agents that cause DNA base damage. In contrast, Yamaizumi and Sugano (176) reported induction of p53 accumulation in XPA fibroblasts at even lower doses of UV in comparison to repair proficient fibroblasts. Interestingly, they also showed that induction of p53 was achieved at lower UV doses in cells from patients with CS, that are defective in gene- and strand-specific DNA repair (211). Therefore, they concluded that p53 accumulation was due to accumulation of UV-induced DNA base damage on actively transcribed genes, with concomitant impaired RNA synthesis. Whatever the roles of (preferential) NER or RNA synthesis in triggering pathway(s) for p53 accumulation upon DNA damage may be, there are indications that DNA strand breaks could be sufficient to and probably necessary for induction of p53 accumulation upon DNA damage $(179,180,183)$.

\subsubsection{Poly(ADP-ribose) polymerase. Possible involvement in DNA damage inducible pathways of p53 accumulation?}

Since PADPRT also requires the presence of DNA strand breaks for its activation $(92,107,109)$, it can be hypothesized that poly(ADP-ribose) polymers may be involved in DNA-damage inducible pathway(s) of p53 accumulation and cell cycle arrest. As mentioned before, poly(ADP-ribose) polymers are formed within minutes after treatment with DNA damaging agents, while detectable p53 accumulation takes place after one to several hours $(176,182)$. This might implicate that poly(ADP-ribose) polymer formation precedes p53 accumulation. It is tempting to speculate that PADPR-induced chromatin decondensation may result in facilitated access of other factors involved in DNA-damage-induced cascade(s) leading to p53 accumulation. Alternatively, temporarily shielding by PADPRT of DNA strand breaks (120) may constitute itself an early emergency signal that turns on other factors, involved in p53 accumulation. Fritsche et al. (182) proposed that a drug-induced conformational change may be required for p53 stabilization. Perhaps poly(ADP-ribose) polymers may directly interact with wild-type p53 protein and thereby contribute to its metabolic stabilization.

At present, it is unknown whether p53 accumulation is involved in protective pathways with regard to the onset of carcinogenesis in humans exposed in vivo to environmental carcinogens. One may hypothesize that, besides enhancement of efficiency of DNA repair mechanisms themselves, 
improved PADPR in humans may also contribute to pathways of DNA damageinducible p53-mediated cell cycle arrest in carcinogen-exposed target tissues.

\subsection{Benzo[a]pyrene and its reactive diolepoxides}

\subsubsection{Benzo[a]pyrene and its reactive diolepoxides. Model compounds to study DNA damage, DNA repair, mutagenicity and carcinogenicity}

Polycyclic aromatic hydrocarbons (PAH) represent a group of chemicals consisting of compounds with two or more condensed benzene rings. $\mathrm{PAH}$ are widely distributed into the environment and may originate from coal tar, petroland diesel engines, domestic heating systems, power plants, tobacco smoke and charcoal-grilled food. Even generally used anti-dandruff shampoos, based on coal tar extracts, have been shown to contain considerable amounts of PAH (211). Associations have been reported between occupational PAH exposure and human carcinogenesis (212-214). Nowadays, 11 PAH have been classified as full carcinogens in experimental animals (215). Among a total of approximately 500 $\mathrm{PAH}$, the most abundant and frequently studied is benzo[a]pyrene (B[a]P). Total environmental emission of this carcinogenic PAH is estimated to be about 1200 tons per year (USA) (216).

$\mathrm{B}[\mathrm{a}] \mathrm{P}$ requires metabolic activation to electrophylic intermediates that can react with DNA, before it can exert its carcinogenic action. In 1974, Sims et al. proposed that after conversion of benzo[a]pyrene to the 7,8 dihydrodiol, subsequent conversion to a 9,10 diol-epoxide yields the ultimate carcinogen form of B[a]P. Later, it was shown that $\mathrm{B}[\mathrm{a}] \mathrm{P}$ is first metabolized by cytochrome $\mathrm{p} 450$-dependent monooxygenases to a mixture of stereoisomers consisting of (+)-7,8-epoxide and $(-)-7,8$ epoxide. These can be converted by epoxide hydrolases into two 7,8 dihydrodiols, which each can be further oxidized by cytochrome p450-dependent mono-oxygenases towards two 7,8-dihydrodiol-epoxides. The resulting diolepoxides thus comprise two diastereomers, in which the epoxide-oxygen is on the opposite (anti) or same (syn) site of the benzylic ring as the hydroxylgroup in the 7-position. In addition, from each diastereomers, two enantiomers exist. Several studies indicate that the (+)-enantiomer of the antibenzo[a]pyrene diolepoxide has the highest mutagenic and carcinogenic properties (218-222).

\subsubsection{Interactions of ( \pm )-anti-benzo[a]pyrene diolepoxide with DNA}

Most studies with regard to interaction of benzo[a]pyrene diolepoxides with DNA have been performed with $( \pm)$-anti-benzo[a]pyrene diolepoxide $(( \pm)$-anti-BPDE ( \pm )-7 $\beta, 8 \alpha$-dihydroxy- $9 \alpha, 10 \alpha$-epoxy-7,8,9,10-tetrahydrobenzo[a]pyrene), thus comprising the most reactive (+)-anti-enantiomer. The main interaction of 
<smiles></smiles>

(+)-anti-benzo[a]pyrene

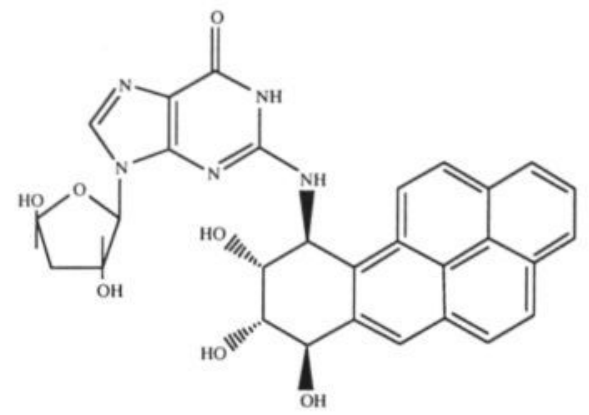

$\mathrm{N}^{2}$-deoxyguanosine

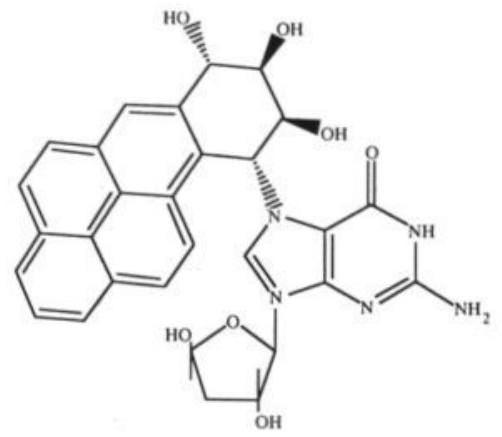

N7-deoxyguanosine

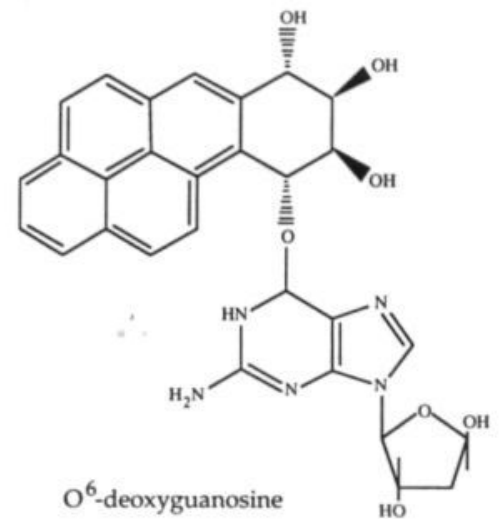

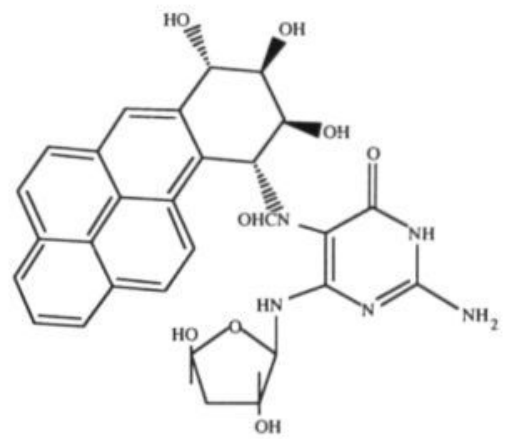

N7-deoxyguanosine imidazole ring-open product

Figure 1.4. anti-benzo[a]pyrene diolepoxide $((+)$-enantiomer) and anti-benzo[a]pyrene diolepoxide deoxyguanosine adducts. 
$( \pm)$-anti-BPDE with DNA in vivo and in vitro takes place between the benzylic $\mathrm{C} 10$ atom of the diolepoxide and the exocyclic nitrogen atom $\left(\mathrm{N}^{2}\right)$ on $\mathrm{dG}$, mainly via trans-addition of the (+)-enantiomer (Figure 1.4) (epoxide ring-opening at the same site as the hydroxylgroup in the 7-position) $(10,223-226)$. Formation of cis-( \pm )-anti-BPDE- $\mathrm{N}^{2}$-dG adducts (epoxide-ring opening at the opposite side as the hydroxylgroup on the 7-position) has also been reported $(227,228)$. The $\mathrm{N}^{2}$-dG adduct itself is considered to be chemically stable, but it has been postulated that slow rearrangement of the adduct could result in formation of AP sites and subsequent DNA strand-breakage, after AP-endonuclease attack. (229-231), However, Sage and Haseltine (226) argued against this mechanism.

Several other interactions of $( \pm)$-anti-BPDE with $\mathrm{dG}$ have been shown to occur in vitro. Osborne et al. (232) showed formation of $\mathrm{O}^{6}$-substituted dG, N7$\mathrm{dG}$ and the N7-dG imidazole ring-open product (Figure 1.4). They further showed that interaction between DNA and the (-)-anti-isomer yielded predominantly $\mathrm{O}^{6}$ - and N7-dG.

There is also evidence for formation of ( \pm )-anti-BPDE adducts with deoxyadenosine and deoxycytidine, but not with deoxythymidine $(10,224,225,233)$. Jeffrey et al. (223) reported both the cis and trans addition of the exocyclic $\mathrm{N}^{6}$ group of adenine to the benzylic $\mathrm{C} 10$ position of the diol-epoxide. Recently, these cis and trans-adducts have been characterized in more detail (228).

Several studies indicate that $( \pm)$-anti-BPDE induces in vitro and in vivo formation of strand breaks under alkaline conditions $(226,230,231,234-236)$. These lesions may represent AP sites, originating from unstable adducts, probably N7dG. $(226,230,234,235)$. An early proposal was that $( \pm)$-anti-BPDE-DNA interaction results in formation of unstable phosphotriesters, causing DNA strand scission (237). However, later findings argue against phosphotriester formation, in favour of AP sites, as intermediates in ( \pm )-anti-BPDE-induced DNA strand break formation $(229,234)$.

\subsubsection{Repair of ( \pm )-anti-benzo[a]pyrene diolepoxide-induced DNA damage}

The use of carcinogens in studying DNA repair activities in human cells ex vivo, that first need to be metabolized before interaction with DNA can take place, has disadvantages. In this case, the extent of damage at a particular time point after treatment will be the resultant of continued interaction of reactive intermediates with DNA and repair processes, making conclusions regarding the latter process complicated. Initial carcinogen-DNA interaction may be related to metabolism, detoxification of reactive intermediates and kinetic processes, resulting for example in delayed release of parent compound or metabolites from other intracellular compartments. In case of $\mathrm{B}[\mathrm{a}] \mathrm{P}$, one can exclude at least the first process by use of the reactive diolepoxides in DNA repair studies (( \pm )-antiBPDE). 
Several studies indicate that mammalian and human cells are capable of repair of ( \pm )-anti-BPDE-induced DNA damage. In 1978, repair of ( \pm )-anti-BPDEinduced DNA damage was reported for the first time by Day et al. (238) in human fibroblasts and by Cerutti et al. (239) in human alveolar tumor cells. Further, removal of ( \pm -anti-BPDE adducts was shown in human lung cells (240). Yang et al. $(21,39)$ reported error-free removal of the main $\mathrm{N}^{2}-\mathrm{dG}$ adduct in human fibroblasts, while removal was absent in XP fibroblasts $(21,22,39)$. Thus, repair of certain ( \pm )-anti-BPDE-induced DNA adducts may proceed through NER mechanisms. Another finding, giving indirect evidence for possible excision of $( \pm)$-anti-BPDE induced DNA adducts, was that in vitro ( \pm )-anti-BPDE-modified plasmid DNA could be cleaved by the purified E. coli $\operatorname{Uvr}(\mathrm{A}) \mathrm{BC}$ exinuclease system (40). Thus, it was shown that, at least in vitro, ( \pm )-anti-BPDE induced DNA damage was substrate for a prokaryotic NER mechanism. Using this Uvr(A)BC exinuclease system, Van Houten et al. (241), showed that DNA extracted from ex vivo ( \pm )-anti-BPDE-treated normal fibroblasts had, with increasing time after treatment, fewer number of endonuclease sensitive sites, in comparison to DNA obtained from XP fibroblasts. Furthermore, $( \pm)$-anti-BPDE has been found to induce UDS in human fibroblasts $(242)$, PBLs $(236,243)$ and cultured mouse epidermal keratinocytes (244). This indicates that in mammalian cells, $( \pm)$-anti-BPDE treatment results in activation of processes that result in DNA repair synthesis. Chen et al. (245) reported preferential removal of ( \pm )anti-BPDE-DNA adducts from the active hprt gene of human fibroblasts, mainly from the actively transcribed strand. These findings suggests that $( \pm)-$ anti-BPDE-induced DNA adducts are substrate for human transcription-coupled NER mechanisms (Figure 1.1). Further, these findings also explain why, in the absence of repair, mutations induced by ( \pm )-anti-BPDE have been found to be related to pre-mutagenic lesions present in both strands of the hprt gene, while in presence of repair, mutations were only confined to pre-mutagenic lesions in the non-transcribed strand $(246,247)$. This emphasizes again the important role of functional (preferential, strand-specific) DNA repair mechanisms in prevention of mutagenesis.

Repair of unstable N7-guanine adducts has not been directly demonstrated yet in mammalian cells ex vivo. Moran and Ebisuzaki (231) observed formation of alkali-labile sites in HeLa cells, after ( \pm )-anti-BPDE-treatment. However, these sites were no substrate for a purified AP-endonuclease $e x$ vivo. Thus, far from being conclusive, these data might indicate the absence of repair of AP-sites, arisen from $( \pm$ )-anti-BPDE-induced unstable N7-guanine adducts.

There are no indications for the existence of proteins that can remove in a direct manner large $\left( \pm\right.$ )-anti-BPDE-DNA adducts, comparable to $\mathrm{O}^{6}$-alkylguanine DNA alkyltransferase action on smaller alkyl adducts. 


\subsection{Aims and outline of this Thesis}

Electrophylic intermediates from various chemical or physical carcinogens may damage DNA and other intracellular macromolecules in numerous ways. Moreover, upon DNA replication or cell division, DNA damage may lead to several irreversible genetic alterations. The onset of carcinogenesis is believed to be directly related to these genetic alterations. Especially, structural alterations in proto-oncogenes or tumour suppressor genes are presumed to result in loss of normal cell growth control.

To maintain genetic integrity, biological organisms including humans, have developed DNA repair mechanisms. The importance of adequate DNA repair mechanisms is illustrated by the fact that absence of a particular form of DNA repair has been shown to predispose human individuals to cancer. In order to gain insight into mechanisms of human carcinogenesis, it is of fundamental importance to understand DNA repair processes. Moreover, it is tempting to hypothesize that upregulation of DNA repair activities may result in decreased DNA damage remaining after exposure to carcinogens, and thereby contribute to a reduced risk for the onset of cancer. Approaches that can modulate DNA repair activities in humans are therefore worthwhile to investigate.

The purposes of the studies described in this Thesis therefore were to investigate the impact of modulating factors involved in human DNA repair. In particular, the role of PADPR in DNA repair was explored. PADPR, catalyzed by the enzyme PADPRT, is rapidly triggered by DNA damaging agents that cause direct or indirect DNA strand break formation. The enzyme transfers the ADPribose groups of $\mathrm{NAD}^{+}$into linear and branched poly(ADP-ribose) polymers. Several roles for PADPR during DNA repair have been proposed: direct modification of other repair enzymes; increased access for other repair enzymes to damaged sites by transient chromatin decondensation; temporarily DNA strand break protection until other DNA repair enzymes are present at damaged sites. Moreover, it can be hypothesized that PADPR may be involved in DNA damage-inducible pathways of cell cycle arrest. These pathways would allow damaged cells to perform repair for a longer period of time, prior to onset of DNA replication or cell division.

As indicated, $\mathrm{NAD}^{+}$is absolutely required as substrate for PADPR. In humans, intake of niacin may influence intracellular $\mathrm{NAD}^{+}$-levels and therefore modulate the efficiency of DNA repair in target organs. It is therefore tempting to speculate that supplementation of carcinogen-exposed individuals with niacin may ultimately result in reduced cancer risk. Further, at present, there is indirect evidence that induction of PADPRT is involved in AR, the phenomenon that ex vivo pre-exposed PBLs become less susceptible to deleterious genotoxic effects induced by exposure to higher levels of genotoxic agents. Similar PADPRTdependent adaptive mechanisms may occur in humans chronically exposed to 
low levels of environmental genotoxic carcinogens. Furthermore, in response to DNA damage, activation of PADPRT and accumulation of p53 - the tumour suppressor protein supposed to contribute to prevention of carcinogenesis by inducing mechanisms which select against heavily damaged cells in favour of efficiently repaired cells - both presumably require the presence of DNA strand breaks. As outlined before, it may be hypothesized that formation of poly(ADPribose) polymers is required for carcinogen-induced p53 accumulation and that these phenomena constitute an anti-carcinogenic mechanism in carcinogenexposed humans. An overview of these hypotheses is given in Figure 1.5.

PBLs are useful tools to study human DNA repair and DNA damage. They can perform DNA repair after ex vivo exposure to a variety of DNA damaging agents $(52,55-59,61,236,243,248)$, which allows to study qualitative and quantitative aspects of DNA repair mechanisms which act in vivo. Further, PBLs can be used to determine in vivo DNA damage which can cause chromosomal damage or mutagenesis, after stimulation to proliferation ex vivo $(249,250)$. Given the fact that increased lymphocytic chromosomal damage (251) and decreased lymphocytic DNA repair capacity (54) have been associated with increased risk for cancer, phenomena observed in PBLs may represent processes that are involved in development of cancer in carcinogen-exposed target organs. Studying these phenomena in PBLs may therefore be relevant to gain insight in the roles of DNA damage and DNA repair in human carcinogenesis. Further, since PBLs can be easily obtained, it is possible to estimate $e x$ vivo the effects of administration of modulating factors to (carcinogen-exposed) populations on DNA repair in vivo.

As indicated, treatment of human cells with ( \pm )-anti-BPDE, benzo[a]pyrene metabolites comprising the most carcinogenic and mutagenic (+)-enantiomer, has been shown to result in formation of several DNA adducts and DNA strand breaks and to induce DNA repair processes. Therefore, in combination with PBLs, these reactive diolepoxides may be used as model compounds to study DNA damage and DNA repair in humans ex vivo.

In the following Chapters, studies are described which attempt to modulate the extent of PADPR in humans and, in relation to this, to modulate the activity of DNA repair mechanisms and the extent of DNA damage, measured ex vivo in PBLs either directly or after induction by $( \pm)$-anti-BPDE. It is hypothesized that modulation of PADPRT activity in human PBLs, either by in vivo nicotinic acid supplementation, by low ex vivo pre-exposure to ( \pm )-anti-BPDE, or by ex vivo treatment with PADPRT inhibitors, will result in alteration of $(( \pm)$-anti-BPDEinduced) DNA repair activities and p53 tumour suppressor protein accumulation, and, in relation to this, in alteration in the extent of $(( \pm)$-antiBPDE-induced) DNA damage.

In Chapter 2, a newly developed assay to determine the persistence of $( \pm$ )anti-BPDE-N2 ${ }^{2}$-dG adducts in isolated $( \pm)$-anti-BPDE-treated PBLs is described. 

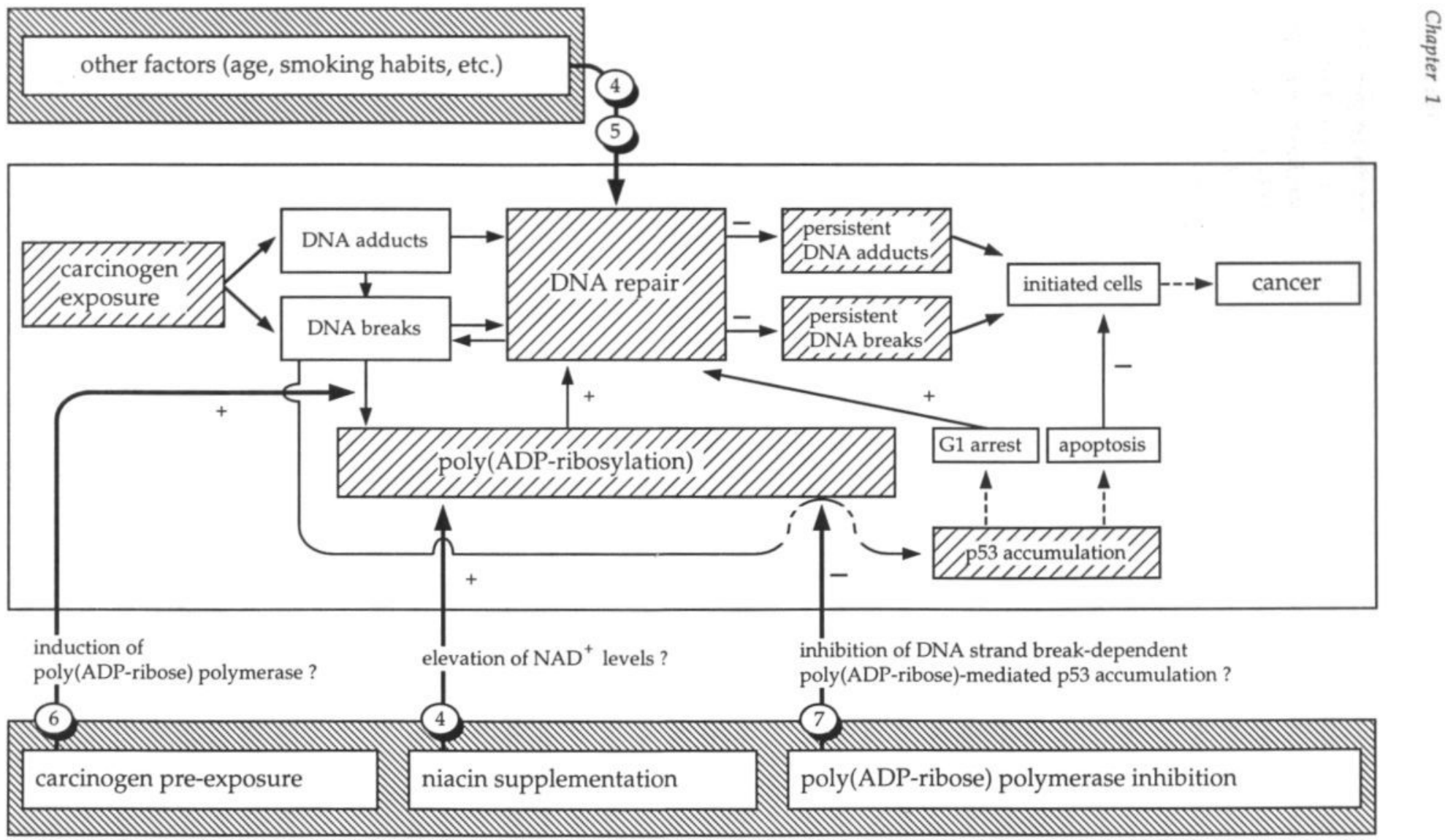

Figure 1.5. Overview of hypotheses regarding modulating factors on poly(ADP-ribosylation) and DNA repair. Phenomena shown within lightly shaded areas ( $\square Z$ ) are subject to study in this thesis. Numbers represent chapters in which the particular hypothesis is addressed. 
The aim of the study, described in Chapter 3, was to investigate whether PADPR is triggered during repair of ( \pm )-anti-BPDE-induced DNA damage in PBLs. In Chapter 4, an attempt is described to modulate PADPR-dependent DNA repair in vivo in humans. The purpose of this study was to improve endogenous niacin status by supplementing human smoking volunteers with nicotinic acid. Moreover, the effects of nicotinic acid supplementation on DNA repair and PADPR in PBLs, induced by $( \pm)$-anti-BPDE treatment $e x$ vivo were examined. Also, the effects of in vivo nicotinic acid supplementation on lesions causing chromosomal damage and mutagenesis ex vivo were determined. Chapter 5 describes age-related correlations found in these volunteers, prior to nicotinic acid supplementation, between ex vivo ( \pm )-anti-BPDE-induced repair synthesis and parameters of cytogenetic damage in PBLs. In Chapter 6, the effects of low $( \pm)$-anti-BPDE pre-exposure on $( \pm)$-anti-BPDE-induced DNA damage and repair synthesis were examined. The purpose of this study was to investigate whether pre-exposure to low levels of PAH, like ( \pm )-anti-BPDE, can result in the induction of adaptive repair mechanism(s), comparable as those, known to occur for IR and alkylating agents. Further, the potential roles of NER mechanisms and PADPR in this process were determined. In Chapter 7, attention is paid to DNA damage-inducible accumulation of tumor suppressor protein p53. Experiments were performed to determine whether $( \pm)$-anti-BPDE induces p53 accumulation in isolated PBLs. Furthermore, by using an inhibitor of PADPRT, the role of PADPR as potential interjacent event between carcinogen-induced DNA strand break formation and p53 accumulation, was determined.

\section{References}

1. Pitot, H.C. (1990) Mechanisms of chemical carcinogenesis: theoretical and experimental bases. In: Cooper, C.S., Grover, P.L. (eds.) Chemical Carcinogenesis and Mutagenesis, Vol I, pp. 3-32. New York: Raven Press.

2. Doll, R., Peto, R. (1981) The causes of cancer: quantitative estimates of avoidable risks in the United States today. J. Natl. Cancer Inst., 66, 1191-1308.

3. Miller, J.A., Milller, E.C. (1969) The metabolic activation of carcinogenic aromatic amines and amides. Prog. Exp. Tumor Res., 11, 273-301.

4. Lanfrancone, L., Pelicci, G., Pelicci, P.G. (1994) Cancer genetics. Curr. Opin. Genet. Dev., 4, 109-119.

5. Levine, A.J., Perry, M.E., Chang, A., Silver, A., Dittmer, D., Wu, M., Welsh, D. (1994) The 1993 Walter Hubert Lecture: The role of p53 tumour-suppressor gene in tumorigenesis. Br. J. Cancer, 69, 409-416.

6. Fearon, E.R., Vogelstein, B. (1990) A genetic model for colorectal tumorigenesis. Cell, 61, 759-767.

7. Hall, M., Grover, P.L. (1990) Polycyclic aromatic hydrocarbons: metabolism, activation and tumour initiation. In: Cooper, C.S., Grover, P.L. (eds.) Chemical Carcinogenesis and Mutagenesis, Vol I, pp. 327-372. New York: Raven Press.

8. Marsch, G.A., Jankowiak, R., Small, G.J., Hughes, N.C., Phillips, D.H. (1992) Evidence of involvement of multiple sites of metabolism in the in vivo covalent binding of dibenzo[a,h,]pyrene to DNA. Chem. Res. Toxicol., 5, 765-772.

9. Jeffrey, A.M., Jenette, K.W., Blobstein, S.H., Weinstein, I.B., Beland, F.A., Harvey, 
R.G., Kasai, H., Miura, I., Nakanishi, K. (1976) Benzo[a]pyrene-nucleic acid derivative found in vivo: structure of a benzo[a]pyrenetetrahydrodiol epoxideguanosine adduct. J. Am. Chem. Soc., 98, 5714-5715.

10. Osborne, M.R., Beland, F.A., Harvey, R.G., Brookes, P. (1976) The reaction of ( \pm )$7 \alpha, 8 \beta$-dihydroxy-9 $\beta, 10 \beta$-epoxy-7,8,9,10-tetrahydrobenzo[a]pyrene with DNA. Int. J. Cancer, 18, 362-368.

11. Groopman, J.D., and Cain, L.G. (1990) Interactions of fungal and plant toxins with DNA: aflatoxins, sterigmatocystin, safrole, cycasin, and pyrrolizidine alkaloids. In: Cooper, C.S., Grover, P.L. (eds.) Chemical Carcinogenesis and Mutagenesis, Vol I, pp. 373-407. New York: Raven Press.

12. Bartsch, H., Barbin, A., Marion, M.-J., Nair, J., Guichard, Y. (1994) Formation, detection, and role in carcinogenesis of ethenobases in DNA. Drug Metabolism Rev., 26, 349-371.

13. Molinete, M., Vermeulen, W., Bürkle, A., Ménissier-de Murcia, Küpper, J.H., Hoeijmakers, J.H.J., de Murcia, G. (1993) Overproduction of the poly(ADP-ribose) DNA-binding domain blocks alkylation-induced DNA repair synthesis in mammalian cells. EMBO J., 12, 2109-2117.

14. Satoh, M.S., Poirier, G.G., Lindahl, T. (1993) NAD ${ }^{+}$-dependent repair of damaged DNA by human cell extracts. J. Biol. Chem., 268, 5480-5487.

15. Wallace, S.S. (1988) AP endonucleases and DNA glycosylases that recognize oxidative DNA damage. Environ. Mol. Mutagen., 12, 431-477.

16. Halliwell, B., Aruoma, O.I. (1991) DNA damage by oxygen-derived species. Its mechanism of action and measurement in mammalian systems. FEBS Lett., 281, 9-19.

17. Wolff, S., Afzal, V., Jostes, R.F., Wiencke, J.K. (1993) Indications of repair of radoninduced chromsome damage in human lymphocytes: an adaptive response induced by low doses of X-rays. Environ. Health Perspect., 101s, 73-77.

18. Janssen, Y.M.W. (1993) Molecular stress responses to mineral dusts. Rodent lungs and pulmonary target cells as models to study the toxicity of asbestos fibers and related mineral dusts. Thesis. Maastricht, The Netherlands.

19. Cleaver, J.E. (1968) Defective repair replication of DNA in xeroderma pigmentosum. Nature, 218, 652-656.

20. Sancar, A. (1994) Mechanisms of DNA excision repair. Science, 266, 1954-1956.

21. Yang, Li, L. Maher, V.M., McCormick, J.J. (1982) Relationship between excision repair and the cytotoxic and mutagenic effect of the 'anti' 7,8-diol-9,10-epoxide of benzo[a]pyrene in human cells. Mutat. Res., 94, 435-447.

22. Maher, V.M., McCormick, J.J. (1983) Relationship between excision repair and the cytotoxic and mutagenic action of chemicals and UV radiation. Basic Life Sci., 23, 271-290.

23. Maher, V.M., McCormick, J.J. (1986) Role of DNA lesions and DNA repair in mutagenesis by carcinogens in diploid human fibroblasts. Genetic toxicology of environmental chemicals, part A: basic principles and mechanisms of action, pp. 245253.

24. Inga, A., Iannone, R., Degan, P., Campomenosi, P., Fronza, G., Abbondandolo, A., Menichini, P. (1994) Analysis of 4-nitroquinoline-1-oxide induced mutations at the hprt locus in mammalian cells: possible involvement of preferential DNA repair. Mutagenesis, 9, 67-72.

25. Fishel, R, Lescoe, M.K., Rao, M.R.S., Copeland, N.G., Jenkins, N.A., Garber, J., Kane, M., Kolodner, R (1993) The human mutator gene homologue MSH2 and its association with hereditary nonpolyposis colon cancer. Cell, 75, 1027-1038.

26. Leach, F.S., Nicolaides, N.C., Papadopoulos, N., Liu, B., Jen, J., Parsons, R., Peltomaki, P., Sistonen, P., Aaltonen, L.A., Nystrom-Lahti, M., et al. (1993) Mutations of a mutS homolog in hereditary nonpolyposis colorectal cancer. Cell, 75, 


\section{5-1225.}

27. Bronner, C.E., Baker, S.M., Morrison, PT., Warren, G., Smith, L.G., Lescoe, M.K. Kane, M., Earabino, C., Lipford, J., Lindblom, A., et al. (1994) Mutation in the DNA mismatch repair gene homologue $h M L H 1$ is associated with hereditary non-polyposis colon cancer. Nature, 368, 258-261.

28. Nicolaides, N.C., Papadopoulos, N., Liu, B., Wei, Y.F., Carter, K.C., Ruben, S.M., Rosen, C.A., Haseltine, W.A., Fleischmann, R.D., Fraser, C.M., et al. (1994) Mutations of two PMS homologues in hereditary nonpolyposis colon cancer. Nature, 371, 75-80.

29. Papadopoulos, N., Nicolaides, N.C., Wei, Y.F., Ruben, S.M., Carter, K.C., Rosen, C.A., Haseltine, W.A., Fleischmann, R.D., Fraser, C.M., Adams, M.D., et al. (1994) Mutations of a mutL homolog in hereditary colon cancer. Science, 263, 1625-1629.

30. Myles, G.M., Sancar, A. (1989) DNA repair. Chem. Res. Toxicol., 2, 197-226.

31. Pegg, A.E. (1991) Factors influencing carcinogenesis by alkylating agents. Recent Results Cancer Res., 122, 22-32.

32. Pegg, A.E., Byers, T.L. (1992) Repair of DNA containing $\mathrm{O}^{6}$-alkylguanine. FASEB J., 6, 2302-2310.

33. Koike, G., Maki, H., Takeya, H., Hayakawa, H., Sekiguchi, M. (1990) Purification, structure and biochemical properties of human $\mathrm{O}^{6}$-methylguanine-DNA methyltransferase. J. Biol. Chem., 265, 14754-14762.

34. Tano, K., Shiota, S., Collier, J., Foote, R.S., Mitra, S. (1990) Isolation and structural characterization of a cDNA clone encoding the human DNA repair protein for $\mathrm{O}^{6}$. alkylguanine. Proc. Natl. Acad. Sci. U.S.A., 87, 686-690.

35. Potter, P.M., Rafferty, J.A., Cawkwell, L., Wilkinson, M.C., Cooper, D.P., O'Conner, P.J., Margison, G.P. (1991) Isolation and cDNA cloning of a rat $\mathrm{O}^{6}$-alkylguanine-DNA alkyltransferase gene, molecular analysis of expression in rat liver. Carcinogenesis, 12, 727-733.

36. Maynard Bronstein, S., Skopek, T.R., Swenberg, J.A. (1992) Efficient repair of O6_ ethylguanine, but not $\mathrm{O}^{4}$-ethylthymine or $\mathrm{O}^{2}$-ethylthymine, is dependent upon $\mathrm{O}^{6}$ alkylguanine-DNA alkyltransferase and nucleotide excision repair activities in human cells. Cancer Res., 52, 2008-2011.

37. Sancar, A., Sancar, G.B. (1988) DNA repair enzymes. Annu. Rev. Biochem., 57, 29-67.

38. Dianov, G., Lindahl, T. (1994) Reconstitution of the DNA base excision-repair pathway. Curr. Biol., 4, 1069-1076.

39. Yang, L.L., Maher, V.M., McCormick, J.J. (1980) Error-free excision of the cytotoxic, mutagenic $\mathrm{N}^{2}$-deoxyguanosine DNA adduct formed in human fibroblasts by $( \pm)$ $7 \beta, 8 \alpha$-dihydroxy-9 $\alpha, 10 \alpha$-epoxy-7,8,9,10-tetrahydrobenzo[a]pyrene. Proc. Natl. Acad. Sci. U.S.A., 77, 5933-5937.

40. Seeberg, E., Steinum, A.-L. Nordenskjöld, M., Söderhäll, Jernström, B. (1983) Strandbreak formation in DNA modified by benzo[a]pyrene diolepoxide Quantitative cleavage by Escherichia coli UvrABC endonuclease. Mutat. Res., 112, 139-145.

41. Sancar, A., Franklin, K.A., Sancar, G. Tang, M.S. (1985) Repair of psoralen and acetylaminofluorene DNA adducts by ABC excinuclease. J. Mol. Biol., 184, 725-734.

42. Myers, L.C., Verdine, G.L. (1994) DNA repair proteins. Curr. Opin. Struct. Biol., 4, 51-59.

43. Hoeijmakers, J.H.J. (1993) Nucleotide excision repair I: from E. coli to yeast. Trends Genet., 9, 173-177.

44. Selby, C.P., Witkin, E.M., Sancar, A. (1991) Escherichia coli mfd mutant deficient in "mutation frequency decline" lacks strand-specific repair: in vitro complementation with purified coupling factor. Proc. Natl. Acad. Sci. U.S.A., 88, 11574-11578.

45. Selby, C.P., Sancar, A. (1993) Molecular mechanisms of transcription repair coupling, Science, 260, 53-58.

46. Hoeijmakers, J.H.J. (1993) Nucleotide excision repair II: from yeast to mammals. Trends Genet., 9, 211-217. 
47. Bootsma, D., Hoeijmakers, J.H.J. (1993) DNA repair, engagement with transcription. Nature, 363, 114-115.

48. Hoeijmakers, J.H.J., Bootsma, D. (1994) Incisions for excision. Nature, 371, 654-655.

49. Nichols, A.F., Sancar, A. (1992) Purification of PCNA as a nucleotide excision repair protein. Nucleic Acids Res., 20, 2441-2446

50. Shivji, K.K., Kenny, M.K., Wood, R.D. (1992) Proliferating cell nuclear antigen is required for DNA excision repair. Cell, 69, 367-374.

51. Lezhava, R.A., Prokof, V.V., Mikhel, V.M. (1979) Weakening of the ultraviolet rayinduced unscheduled DNA synthesis in human lymphocytes in extreme old age. Tsitologiia, 21, 1360-1363.

52. Pero, R.W., Östlund, C (1980) Direct comparison, in human resting lymphocytes, of the inter-individual variations in unscheduled DNA synthesis induced by $\mathrm{N}$-acetoxy2-acetylaminofluorene and ultraviolet irradiation. Mutat. Res., 73, 349-361.

53. Dil'man, V.M., Revskoi, S.Yu. (1981) Correlation between DNA repair and cholesterol concentration in blood serum and lymphocytes. Fiziol. Cheloveka, 7, 125-129.

54. Wei, Q., Matanoski, G.M., Farmer, M.A., Hedayati, M.A., Grossman, L. (1993) DNA repair and aging in basal cell carcinoma: a molecular epidemiology study. Proc. Natl. Acad. Sci. U.S.A., 90, 1614-1618.

55. Madden, J.J., Falek, A., Shafer, D.A., Glick, J.H. (1979) Effects of opiates and demographic factors on DNA repair synthesis in human leukocytes. Proc. Natl. Acad. Sci. U.S.A., 76, 5769-5773.

56. Benigni, R., Calcagnile, A., Fabri, G., Giuliani, A., Leopardi, P., Paoletti, A. (1984) Biological monitoring of workers in the rubber industry. II. UV-induced unscheduled DNA synthesis in the lymphocytes of vulcanizers. Mutat. Res., 138, 105-111.

57. Kovacs, E., Weber, W., Müller, Hj. (1984) Age-related variation in the DNA-repair synthesis after UV-C irradiation in unstimulated lymphocytes of healthy blood donors. Mutat. Res., 131, 231-237.

58. Topinka, J., Binková, B., Srám, R.J., Fojtiková, I. (1991) DNA-repair capacity and lipid peroxidation in chronic alcoholics. Mutat. Res., 263, 133-136.

59. Celotti, L., Furlan, D., Ferraro, P., Levis, A.G. (1989) DNA repair and replication in lymphocytes from smokers exposed in vitro to UV light. Mutagenesis, 4, 82-86.

60. Au, W.W., Walker, D.M., Ward, J.B., Whorton, M.S., Legator, M.S., Singh, V. (1991) Factors contributing to chromosomal damage in lymphocytes of cigarette smokers. Mutat. Res., 260, 137-144.

61. Oesch, F., Aulmann, W., Platt, K.L., Doerjer, G. (1987) Individual differences in DNA repair capacities in man. Arch. Toxicol. Suppl., 10, 172-179.

62. Bradley, W.G., Polinsky, R.J., Pendelbury, W.W., Jones, S.K., Nee, L.E., Bartlett, J.D., Hartshorn, J.N., Tandan, R., Magin, G.K., Robinson, S.H. (1989) DNA repair deficiency for alkylation damage in cells from alzheimer's disease patients. Prog. Clin. Biol. Res., 317, 715-732.

63. Pero, R.W., Bryngelsson, T., Widegren, B., Högstedt, B., Welinder, H. (1982) A reduced capacity for unscheduled DNA synthesis in lymphocytes from individuals exposed to propylene oxide and ethylene oxide. Mutat. Res., 104, 193-200.

64. Celotti, L., Biasin, R., Ferraro, P., Fiorentino, M. (1990) Effects of in vivo exposure to antineoplastic drugs on DNA repair and replication in human lymphocytes. Mutat. Res., 245, 217-222.

65. Jacobson, E.L. and Jacobson, M.K. (1993) A biomarker for the assessment of niacin nutriture as a potential preventive factor in carcinogenesis. J. Intern. Med., 233, 59-62.

66. Chambon, P., Weill, J.D., Mandel, P. (1963) Nicotinamide mononucleotide activation of a new DNA-dependent polyadenylic acid synthesizing nuclear enzyme. Biochem. Biophys. Res. Commun., 11, 39-43.

67. Yoshihara, K., Hashida, T., Tanaka, Y., Matsunami, N., Yamaguchi, A., Kamiya, T. 
(1981) Mode of enzyme-bound poly(ADP-ribose) synthesis and histone modification by reconstituted poly(ADP-ribose) polymerase-DNA-cellulose complex. J. Biol. Chem., 256, 3471-3478.

68. Poirier, G.G., Niedergang, C., Champagne, M., Mazen, A., Mandel, P. (1982) Adenosine diphosphate ribosylation of chicken-erythrocyte histones $\mathrm{H} 1, \mathrm{H} 5$ and high-mobility-group proteins by purified calf-thymus poly(adenosinediphosphateribose) polymerase. Eur. J. Biochem., 127, 437-442.

69. Kreimeyer, A., Wielckens, K., Adamietz, P., Hilz, H. (1985) DNA repair-associated ADP-ribosylation in vivo. Modification of histone $\mathrm{H} 1$ differs from that of the principal acceptor proteins. J. Biol. Chem., 259, 890-896.

70. Krupitza, G., Cerutti, P. (1989) Poly(ADP-ribosylation) of histones in intact human keratinocytes. Biochemistry, 28, 4054-4060.

71. Realini, C.A., Althaus, F.R. (1992) Histone Shuttling by Poly(ADP-ribosylation). J. Biol. Chem., 267, 18858-18865.

72. Thomassin, H., Ménard, L., Hengartner, C., Kirkland, J.B., Poirier, G.G. (1992) Poly(ADP-ribosyl)ation of chromatin in an in vitro poly(ADP-ribose)-turnover system. Biochim. Biophys. Acta, 1137, 171-181.

73. Das, B.R. (1993) Increased ADP-ribosylation of histones in oral cancer. Cancer Lett., 73, 29-34.

74. Yoshihara, K., Itaya, A., Tanaka, Y., Ohashi, Y., Ito, K., Teraoka, H., Tsukada, H., Masukage, A., Kamiya, T. (1985) Inhibition of DNA polymerase $\alpha$, DNA polymerase $\beta$, terminal nucleotidyltransferase and DNA ligase II by poly(ADP-ribosyl)ation reaction in vitro. Biochem. Biophys. Res. Commun., 128, 61-67.

75. Teraoka, H., Sumikawa, T., Tsukada, K. (1986) Purification of DNA ligase II from calf thymus and preparation of rabbit antibody against calf thymus DNA ligase II. J. Biol. Chem., 261, 6888-6892.

76. Ferro, A.M., Higgins, N.P., Olivera, B.M., (1983) Poly(ADP-ribosylation) of a DNA topoisomerase. J. Biol. Chem., 258, 6000-6003.

77. Jongstra-Bilen, J., Ittel, M.E., Niedergang, C., Vosberg, H.P., Mandel, P. (1983) DNA topoisomerase I from calf thymus is inhibited in vitro by poly(ADP-ribosylation). Eur. J. Biochem., 136, 391-396.

78. Darby, M., Schmitt, B., Jongstra-Bilen, J., Vosberg, H.P. (1985) Inhibition of calf thymus type II DNA topoisomerase by poly(ADP-ribosylation). EMBO J., 4, 21292134.

79. Boulikas, T. (1990) Poly(ADP-ribosylated) histones in chromatin replication. J. Biol. Chem., 265, 14638-14647.

80. Tanuma, S.I., Johnson, L.D., Johnson, G.S. (1983) ADP-ribosylation of chromosomal proteins and mouse mammary tumor virus gene expression: Glucocortinoids rapidly decrease endogenous ADP-ribosylation of nonhistone high mobility group 14 and 17 proteins. J. Biol. Chem., 258, 15371-15375.

81. Cardenas-Corona, M.E., Jacobson, E.L., Jacobson, M.K. (1987) Endogenous polymers of ADP-ribose are associated with the nuclear matrix. J. Biol. Chem., 262, 1486314866.

82. Alvarez-Gonzalez, R., Ringer, D.P. (1988) Nuclear matrix associated poly(ADPribose) metabolism in regenerating rat liver. FEBS Lett., 236, 362-366.

83. Kawaichi, M., Ueda, K., Hayaishi, O. (1981) Multiple autopoly(ADP-ribosyl)ation of rat liver poly(ADP-ribose) synthetase: Mode of modification and properties of automodified synthetase. J. Biol. Chem., 256, 9483-9489.

84. Adamietz, P. (1987) Poly(ADP-ribose) synthase is the major endogenous nonhistone acceptor for poly(ADP-ribose) in alkylated rat hepatoma cells. Eur. J. Biochem., 169, 365-372.

85. Satoh, M.S., Lindahl, T. (1992) Role of poly(ADP-ribose) formation in DNA repair. 
Nature, 356, 356-358.

86. Cherney, B.W., McBride, O.W., Chen, D., Alkhatib, H., Bhatia, K., Hensley, P., Smulson, M.E. (1987) cDNA sequence, protein structure, and chromosomal location of the human gene for poly(ADP-ribose) polymerase. Proc. Natl. Acad. Sci. U.S.A., 84, 8370-8374.

87. Baumgartner, M., Schneider, R., Auer, B., Herzog, H., Schweiger, M., HirschKaufmann (1992) Fluorescence in situ mapping of the human nuclear $\mathrm{NAD}^{+} \mathrm{ADP}$ ribosyltransferase gene (ADPRT) and two secondary sites to human chromosomal bands 1q42, 13q34, and 14q24. Cytogenet. Cell Genet., 61, 172-174.

88. Juarez-Salinas, H., Levi, V., Jacobson, E.L., Jacobson, M.K. (1982) Poly(ADP-ribose) has a branched structure in vivo. J. Biol. Chem., 257, 607-609.

89. Boulikas, T. (1993) Poly(ADP-ribosyl)ation, DNA strand breaks, chromatin and cancer. Toxicol. Lett., 64, 129-150.

90. Oka, J., Ueda, K., Hayaishi, O., Komura, H., Nakanishi, K. (1984) ADP-ribosyl protein lyase. Purification, properties and identification of the product. J. Biol. Chem., 259, 986-995.

91. Boulikas, T. (1991) Relation between carcinogenesis, chromatin structure and poly(ADP-ribosylation). Anticancer Res., 11, 489-528.

92. Alvarez-Gonzalez, R., Eichenberger, R., Loetscher, P., Althaus, F. (1986) A new highly selective physicochemical as'say to measure NAD ${ }^{+}$in intact cells. Anal. Biochem., 156, 473-480.

93. Aboul-Ela, N., Jacobson, E.L., Jacobson, M.K. (1988) Labeling methods for the study of poly- and mono(ADP-ribose) metabolism in cultured cells. Anal. Biochem., 174, $239-250$.

94. Rankin, P.W., Jacobson, E.L., Benjamin, R.C., Moss, J., Jacobson, M.K. (1989) Quantitative studies of inhibitors of ADP-ribosylation in vitro and in vivo. J. Biol. Chem., 264, 4312-4317.

95. Sims, J.L., Sikorski, G.W., Catino, D.M., Berger, S.J., Berger, N.A. (1982) Poly(adenosinediphosphoribose) polymerase inhibitors stimulate unscheduled deoxyribonucleic acid synthesis in normal human lymphocytes. Biochemistry, 21, 1813-1821.

96. Skidmore, C.J., Davies, M.I., Goodwin, P.M., Halldorsson, H., Lewis, P.J., Shall, S., Zia'ee, A.-A. (1979) The involvement of poly(ADP-ribose) polymerase in the degradation of NAD caused by $\gamma$-radiation and $N$-methyl- $N$-nitrosourea. Eur. J. Biochem., 101, 135-142.

97. Jacobson, E.L., Antol, K.M., Juarez-Salinas, H., Jacobson, M.K. (1983) Poly(ADPribose) metabolism in ultraviolet irradiated human fibroblasts. J. Biol. Chem., 258, 103-107.

98. Lautier, D., Poirier, D., Boudreau, A., Alaoui Jamali, M.A., Castonguay, A., Poirier, G. (1990) Stimulation of poly(ADP-ribose) synthesis by free radicals in C3H10T1/2 cells: relationship with NAD metabolism and DNA breakage. Biochem. Cell. Biol., 68, 602-608.

99. Pero, R.W., Johnson, D.B., Miller, D.G., Zang, E., Markowitz, M., Doyle, G.A., LundPero, M., Salford, L., Sordillo, P., Raskin, N., Beattie, E.J. (1989) Adenosine diphosphate ribosyl transferase responses to a standardized dose of hydrogen peroxide in the mononuclear leukocytes of patients with a diagnosis of cancer. Carcinogenesis, 10, 1657-1664.

100. Pero, R.W., Olsson, H., Killander, F., Troll, W. (1992) Elevation of ADP-ribosylation as an indicator of mononuclear leucocyte responsiveness in breast cancer patients treated with tamoxifen. Eur. J. Cancer, 28A, 1803-1806.

101. Schraufstatter, I.U., Hinshaw, D.B., Hyslop, P.A., Spragg, R.G., Cochrane, C.G. (1986) Oxidant injury of cells. DNA strand-breaks activate polyadenosine 
diphosphate-ribose polymerase and lead to depletion of nicotinamide adenine dinucleotide. J. Clin. Invest., 77, 1312-1319.

102. Junod, A.F., Jornot, L., Petersen, H. (1989) Differential effects of hyperoxia and hydrogen peroxide on DNA damage, polyadenosine diphosphate-ribose polymerase activity, and nicotinamide adenine dinucleotide and adenosine triphosphate contents in cultured endothelial cells and fibroblasts. J. Cell. Physiol., 140, 177-185.

103. Markowitz, M.M., Johnson, D.B., Pero, R.W., Winawer, S.J., Miller, D.G. (1988) Effects of cumene hydroperoxide on adenosine diphosphate ribosyltransferase in mononuclear leukocytes of patients with adenomatous polyps in the colon. Carcinogenesis, 9, 349-355.

104. Zhao, B., Konno, S., Wu, J.M., Oronsky, A.L. (1990) Modulation of nicotinamide adenine dinucleotide and poly(ADP-ribose) metabolism by calicheamicin $\gamma 1$ in human HL-60 cells. Cancer Lett., 50, 141-147.

105. Singh, N. (1991) Enhanced poly ADP-ribosylation in human leukemia lymphocytes and ovarian cancers. Cancer Lett., 58, 131-135.

106. Bürkle, A., Chen, G., Küpper, J.-H. Grube, K., Zeller, W.J. (1993) Increased poly(ADPribosyl)ation in intact cells by cisplatin treatment. Carcinogenesis, 14, 559-561.

107. Alvarez-Gonzalez, R., Jacobson, M.K. (1987) Characterization of polymers of adenosine diphosphate ribose generated in vitro and in vivo. Biochemistry, 26, 32183224 .

108. Lautier, D., Hoflack, J.-C., Kirkland, J.B., Poirier, D., Poirier, G.G. (1994) The role of poly(ADP-ribose) metabolism in response to active oxygen toxicity. Biochim. Biophys. Acta, 1221, 215-220.

109. Benjamin, R.C., Gill, D.M. (1980) Poly(ADP-ribose) synthesis in vitro programmed by damaged DNA. A comparison of DNA molecules containing different types of strand breaks. J. Biol. Chem., 255, 10502-10508.

110. Creissen, D., Shall, S. (1982) Regulation of DNA ligase activity by poly(ADP-ribose). Nature, 296, 271-272.

111. Durkacz, B.W., Omidiji, O., Gray, D.A., Shall, S. (1980) (ADP-ribose) n participates in DNA excision repair. Nature, 283, 593-596.

112. Zwelling, L.A., Kerrigan, D., Pommier, Y. (1982) Inhibitors of poly-(adenosine diphosphoribose) synthesis slow the resealing rate of X-ray-induced DNA strand breaks. Biochem. Biophys. Res. Commun., 104, 897-902.

113. Moran, M.F., Ebisuzaki, K. (1985) Inhibition of poly(ADP-ribose) polymerase causes increased DNA strand breaks without decreasing strand rejoining in alkylated HeLa cells. FEBS Lett., 190, 279-282.

114. Berger, N.A. (1985) Poly(ADP-ribose) in the cellular response to DNA damage. Radiat. Res., 101, 4-15.

115. Althaus, F.R. (1992) Poly ADP-ribosylation: a histone shuttle mechanism in DNA excision repair. J. Cell Sci., 102, 663-670.

116. Weierska-Gadek, J., Sauermann, G. (1988) The effect of poly(ADP-ribose) on interactions of DNA with histones H1, H3, and H4. Eur. J. Biochem., 173, 675-679.

117. Poirier, G.G., de Murcia, G., Jongstra-Bilen, J., Niedergang, C., Mandel, P. (1982) Poly(ADP-ribosyl)ation of polynucleosomes causes relaxation of chromatin structure. Proc. Natl. Acad. Sci. U.S.A., 79, 3423-3427.

118. Niedergang, C.P., de Murcia, G., Ittel, M.E., Pouyet, J., Mandel, P. (1985) Time course of polynucleosome relaxation and ADP-ribosylation. Correlation between relaxation and histone H1 hyper-ADP-ribosylation. Eur. J. Biochem., 146, 185-191.

119. de Murcia, G., Huletsky, A., Lamarre, D., Gaudreau. A., Pouyet, J., Daune, M., Poirier, G.G. (1986) Modulation of chromatin superstructure induced by poly(ADPribose) synthesis and degradation. J. Biol. Chem., 261, 7011-7017.

120. de Murcia, G., Ménissier-de Murcia, J. (1994) Poly(ADP-ribose) polymerase: a 
molecular nick-sensor. Trends Biochem. Sci., 19, 172-176.

121. Satoh, M.S., Lindahl, T. (1994) Enzymatic repair of oxidative DNA damage. Cancer Res., 54, 1899s-1901s.

122. Berger, N.A., Sims, J.L., Catino, D.M., Berger, S.J. (1983) Poly(ADP-ribose) polymerase mediates the suicide response to massive DNA damage: Studies in normal and DNA-repair defective cells. In: ADP-ribosylation, DNA repair and Cancer (eds.: Miwa, M., Hayaishi, O., Shall, S., Smulson, M., Sugimura, T), pp. 219-226. Japan Sci. Press, Tokyo.

123. Kirkland, J.B. (1991) Lipid peroxidation, protein thiol oxidation and DNA damage in hydrogen peroxide-induced injury to endothelial cells: role of activation of poly(ADPribose) polymerase. Biochim. Biophys. Acta, 1092, 319-325.

124. Nosseri, C., Coppola, S., Ghibelli, L. (1994) Possible involvement of poly(ADPribosyl) polymerase in triggering stress-induced apoptosis. Exp. Cell Res., 212, $367-$ 373.

125. Bhatia, K.G., Cherney, B.W., Huppi, K., Magrath, I.T., Cossman, J., Sausville, E., Barriga, F., Johnson, B., Gause, B., Bonney, G., Neequayi, J., DeBernardi, M., Smulson, E. (1990) A deletion linked to a poly(ADP-ribose) polymerase gene on chromosome 13q33-qter occurs frequently in the normal black population as well as in multiple tumor DNA. Cancer Res., 50, 5406-5413.

126. Teebor, G.W., Becker, F.F. (1971) Regression and persistence of hyperplastic nodules induced by $\mathrm{N}$-2-fluorenylacetamide and their relationship to hepatocarcinogenesis. Cancer Res., 31, 1-3.

127. Cesarone, C.F., Scovassi, A.I., Scarabelli, L., Izzo, R., Orunesu, M., Bertazzoni, U. (1988) Depletion of adenosine diphosphate-ribosyl transferase activity in rat liver during exposure to N2-acetylaminofluorene: effect of thiols. Cancer Res., 48, 35813585 .

128. Kiehlbauch, C.C., Kosanke, S.D., Ringer, D.P. (1993) Changes in levels of ADP-ribose polymers in rat liver during 2-acetylaminofluorene-induced hepatocarcinogenesis. Carcinogenesis, 14, 1435-1440.

129. DiPalma, J.R., Thayer, W.S. (1991) Use of niacin as a drug. Annu. Rev. Nutr., 11, 169-187.

130. Weiner, M., Van Eys, J. (1983) Nicotinic acid, nutrient-cofactor-drug. New York: Dekker.

131. Henderson, L.M. (1983) Niacin. Annu. Rev. Nutr., 3, 289-307.

132. Carson, D.A., Seto, S, Wasson, D.B. (1987) Pyridine nucleotide cycling and poly(ADP-ribose) synthesis in resting human lymphocytes. J. Immunol., 138, 19041907.

133. Micheli, V., Simmonds, H.A. (1989) NAD synthesis by erythrocytes in phosphoribosylpyrophosphate synthetase (PRPPs) superactivity. Adv. Exp. Med. Biol., 253, 1-7.

134. Wohlert, H., Kröger, H., Sörensen, H. (1989) NAD synthesis and ADPR transferase activity in blood lymphocytes of patients suffering from rheumatoid arthritis and of control persons. Clin. Exp. Rheumatol., 7, 525-528.

135. Micheli, V., Simmonds, H.A., Sestini, S., Ricci, C. (1991) Importance of nicotinamide as an NAD precursor in the human erythrocyte. Arch. Biochem. Biophys., 283, 40-45.

136. Micheli, V., Sestini, S., Rocchigiani, M., Pescaglini, M., Ricci, C. (1990) Further insight into NAD synthesis in human erythrocytes: significance and relevance. Biomed. Biochim. Acta, 49, 129-134.

137. Shibata, K., Kawada, T., Iwai, K. (1988) Simultaneous micro-determination of nicotinamide and its major metabolites N1-methylnicotinamide, N1-methyl-2pyridone-5-carboxamide, and N1-methyl-4-pyridone-3-carboxamide by high performance liquid chromatography. J. Chromatogr., 424, 23-28. 
138. Shibata, K., Matsuo, H. (1989) Correlation between niacin equivalent intake and urinary excretion of its metabolites, N1-methylnicotinamide, N1-methyl-2-pyridone5-carboxamide, and N1-methyl-4-pyridone-3-carboxamide, in humans consuming a self-selected food. Am. J. Clin. Nutr., 50, 114-119.

139. Yuyama, S., Suzuki, T. (1991) The excretion of N1-methyl-2-pyridone-5-carboxilic acid and related compounds in human subjects after oral administration of nicotinic acid, trigonalline and N1-methyl-2-pyridone-5-carboxilic acid. Adv. Exp. Med. Biol., 294, 475-479.

140. Berger, N.A., Sikorski, G.W. (1980) Nicotinamide stimulates repair of DNA damage in human lymphocytes. Biochem. Biophys. Res. Commun., 95, 67-72.

141. Park, S.D., Kim, C.G., Kim, M.G. (1983) Inhibitors of poly(ADP-ribose) polymerase enhance DNA strand breaks, excision repair, and sister chromatid exchanges induced by alkylating agents. Environ. Mutagen., 5, 515-525.

142. Pero, R.W., Jonsson, G.G., Persson, L (1983) Unscheduled DNA synthesis induced by $\mathrm{N}$-acetoxy-2-acetylaminofluorene is not sensitive to regulation by ADP-ribosyl transferase. Chem. Biol. Interact., 47, 265-275.

143. Sims, J.L., Berger, S.J., Berger, N.A. (1983) Poly(ADP-ribose) polymerase inhibitors preserve nicotinamide adenine dinucleotide and adenosine $5^{\prime}$-triphosphate pools in DNA-damaged cells: mechanism of stimulation of unscheduled DNA synthesis. Biochemistry, 22, 5188-5194.

144. Kjellén, E., Jonsson, G.G., Pero, R.W., Christensson, P.-I. (1986) Effects of hyperthermia and nicotinamide on DNA repair synthesis, ADP-ribosyl transferase activity, NAD ${ }^{+}$and ATP pools, and cytotoxicity in $\gamma$-irradiated human mononuclear leukocytes. Int. J. Radiat. Biol., 49, 151-162.

145. Marini, M., Zunica, G., Tamba, M., Cossarizza, A., Monti, D., Franceschi, C. (1990) Recovery of human lymphocytes damaged with $\gamma$-radiation or enzymatically produced oxygen radicals: different effects of poly(ADP-ribosyl)polymerase inhibitors. Int. J. Radiat. Biol., 58, 279-291.

146. Riklis, E., Kol, R., Marko, R. (1990) Trends and developments in radioprotection: the effect of nicotinamide on DNA repair. Int. J. Radiat. Biol., 57, 699-708.

147. Oikawa, A., Tohda, H., Kanai, M., Miwa, M., Sugimura, T. (1980) Inhibitors of poly(adenosine diphosphate ribose) polymerase induce sister chromatid exchanges. Biochem. Biophys. Res. Commun., 97, 1311-1316.

148. Weitberg, A.B., Corvese, D. (1990) Niacin prevents DNA strand breakage by adenosine deaminase inhibitors. Biochem. Biophys. Res. Commun., 167, 514-519.

149. Weitberg, A.B. (1989) Effect of nicotinic acid supplementation in vivo on oxygen radical-induced genetic damage in human lymphocytes. Mutat. Res., 216, 197-201.

150. Zhang, J.Z., Henning, S.M., Swenseid, M.E. (1993) Poly(ADP-ribose) polymerase activity and DNA strand breaks are affected in tissues of niacin-deficient rats. $J$. Nutr., 123, 1349-1355.

151. Rawling, J.M., Jackson, T.M., Driscoll, E.R., Kirkland, J.B. (1994) Dietary niacin deficiency lowers tissue poly(ADP-ribose) and NAD ${ }^{+}$concentrations in Fischer-344 rats. J. Nutr., 124, 1597-1603.

152. Fu, C.S., Swensied, M.E., Jacob, R.A., McKee, R.W. (1989) Biochemical markers for assessment of niacin status in young men: levels of erythrocyte niacin coenzymes and plasma tryptophan. J. Nutr., 119, 1949-1955.

153. Jacob, R.A., Swenseid, M.E., McKee, R.W., Fu, C.S., Clemens, R.A. (1989) Biochemical markers for assessment of niacin status in young men: urinary and blood levels of niacin metabolites. J. Nutr., 119, 591-598.

154. Samson, L., Cairns, J. (1977) A new pathway for DNA repair in Escherichia coli. Nature, 267, 281-282.

155. Olivieri, G., Bodycote, J., Wolff, S. (1984) Adaptive response of human lymphocytes to low concentrations of radioactive thymidine. Science, 223, 594-597. 
156. Kaina, B. (1982) Enhanced survival and reduced mutation and aberration frequencies induced in V79 Chinese hamster cells pre-exposed to low levels of methylating agents. Mutat. Res., 93, 195-211.

157. Ikushima, T. (1989) Radio-adaptive response: characterization of a cytogenetic repair induced by low-level ionizing radiation in cultured Chinese hamster cells. Mutat. Res., 227, 241-246.

158. Wojcik, A., Tuschl, H. (1990) Indications of an adaptive response in C57BL mice preexposed in vivo to low doses of ionizing radiation. Mutat. Res., 243, 67-73.

159. von Hofe, E., Kennedy, A.R. (1991) X-ray induction of $\mathrm{O}^{6}$-alkylguanine-DNA alkyltransferase protects against some of the biological effects of $N$-methyl- $N^{\prime}$ nitro- $N$-nitrosoguanidine in C3H 10T1/2 cells. Radiat. Res., 127, 220-225.

160. Osmak, M., Horvat, D. (1992) Chromosomal analysis of chinese hamster V79 cells exposed to multiple $\gamma$-ray fractions: induction of adaptive response to mitomycin $\mathrm{C}$. Mutat. Res., 282, 259-263.

161. Rigaud, O., Papadopoulo, D., Moustacchi, E. (1993) Decreased deletion mutation in radioadapted human lymphoblasts. Radiat. Res., 133, 94-101.

162. Zhou, P.K., Liu, X.Y., Sun, W.Z., Zhang, Y.P., Wei, K. (1993) Cultured mouse SR-1 cells exposed to low dose of $\gamma$-rays become less susceptible to the induction of mutagenesis by radiation as well as bleomycin. Mutagenesis, 8, 109-111.

163. Azzam, E.I., Raaphorst, G.P., Mitchel, R.E.J. (1994) Radiation-induced adaptive response for protection against micronucleus formation and neoplastic transformation in C3 10T1/2 mouse embryo cells. Radiat. Res., 138, s28-s31.

164. Rigaud, O., Moustacchi, E. (1994) Radioadaptation to the mutagenic effect of ionizing radiation in human lymphoblasts: molecular analysis of HPRT mutants. Cancer Res., 54, 1924s-1928s.

165. Mahmood, R., Vasudev, V. (1993) Inducible protective processes in animal systems: IV. Adaptation of mouse bone marrow cells to a low dose of ethyl methanesulfonate. Mutagenesis, 8, 83-86.

166. Mozdarani, H., Saberi, A.H. (1994) Induction of cytogenetic adaptive repsonse of mouse bone marrow cells to radiation by therapeutic doses of bleomycin sulfate and actinomycin D as assayed by the micronucleus test. Cancer Lett., 78, 141-150.

167. Wiencke, J.K., Afzal, V., Olivieri, G., Wolff, S. (1986) Evidence that the $\left[{ }^{3} \mathrm{H}\right]$ thymidine-induced adaptive response of human lymphocytes to subsequent doses of X-rays involves the induction of a chromosomal repair mechanism. Mutagenesis, 1, 375-380.

168. Shadley, J.D., Wolff, S. (1987) Very low doses of X-rays can cause human lymphocytes to become less susceptible to ionizing radiation. Mutagenesis, 2, 95-96.

169. Vijayalaxmi, Burkart, W. (1989) Effect of 3-aminobenzamide on chromosome damage in human blood lymphocytes adapted to bleomycin. Mutagenesis, 4, 187-189.

170. Wiencke, J.K. (1987) Nicotinamide deficiency in human lymphocytes prevents the $\left[{ }^{3} \mathrm{H}\right]$ thymidine-induced adaptive response for the repair of X-ray-induced chromosomal damage. Exp. Cell Res., 171, 518-523.

171. Lane, D.P., Crawford, L.V. (1979) T antigen is bound to a host protein in SV40transformed cells. Nature, 278, 261-263.

172. Li, F.P., Fraumeni, J.F., Mulvihill, J.J., Blattner, W.A., Dreyfus, M.G., Tucker, M.A., Miller, R.M. (1988) A cancer family syndrome in twenty-four kindreds. Cancer Res., 48, 5358-5362.

173. Donehower, L.A., Harvey, M., Slagle, B.L., McArthur, M.J., Montgomery Jr., C.A., Butel, J.S., Bradley, A. (1992) Mice deficient for p53 are developmentally normal but susceptible to spontaneous tumours. Nature, 317, 215-221.

174. Maltzman, W., Czyzyk, L. (1984) UV irradiation stimulates levels of p53 cellular tumor antigen in nontransformed mouse cells. Mol. Cell. Biol., 4, 1689-1694. 
175. Hall, P.A., McKee, P.H., du P. Menage, H., Dover, R., Lane, D.P. (1993) High levels of p53 protein in UV-irradiated normal human skin. Oncogene, 8, 203-207.

176. Yamaizumi, M., Sugano, T. (1994) U.V.-induced nuclear accumulation of p53 is evoked through DNA damage of actively transcribed genes independent of the cell cycle. Oncogene, 9, 2775-2784.

177. Kastan, M.B., Onyekwere, O., Sidransky, D., Vogelstein, B. Craig, R.W. (1991) Participation of p53 protein in the cellular response to DNA damage. Cancer Res., 51, 6304-6311.

178. El-Deiry, W.S., Harper, J.W., O'Connor, P.M., Velculescu, V.E., Canman, C.E., Jackman, J., Pietenpol, J.A., Burrell, M., Hill, D.E., Wang, Y., Wiman, K.G., Mercer, W.E., Kastan, M.B. Kohn, K.W., Elledge, S.J., Kinzler, K.W. Vogelstein, B. (1994) WAF1/CIP1 is induced in p53-mediated G1 arrest and apoptosis. Cancer Res., 54, 1169-1174.

179. Zhan, Q., Bae, I., Kastan, M.B. Fornace, A.J. (1994) The p53-dependent $\gamma$-ray response of GADD45. Cancer Res., 54, 2755-2760.

180. Nelson, W.G. Kastan, M.B. (1994) DNA strand breaks: the DNA template alterations that trigger p53-dependent DNA damage response pathways. Mol. Cell. Biol., 14, 1815-1823.

181. Canman, C.E., Wolff, A.C., Chen, C.-Y., Fornace, A.J. Kastan, M.B. (1994) The p53dependent G1 cell cycle checkpoint pathway and ataxia-telangiectasia. Cancer Res., 54, 5054-5058.

182. Fritsche, M., Haessler, C. Brandner, G. (1993) Induction of nuclear accumulation of the tumor-suppressor protein p53 by DNA-damaging agents. Oncogene, 8, 307-318.

183. Hess, R., Plaumann, B, Schulze Lutum, A., Haessler, C., Heinz, B., Fritsche, M. Brandner, G.(1994) Nuclear accumulation of p53 in response to treatment with DNAdamaging agents. Toxicol. Lett., 72, 43-52.

184. Lane, D.P. (1992) p53, guardian of the genome. Nature, 358, 15-16.

185. Clarke, A.R., Purdie, C.A., Harrison, D.J., Morris, R.G., Bird, C.C., Hooper, M.L., Wyllie, A.H. (1993) Thymocyte apoptosis induced by p53-dependent and independent pathways. Nature, 362, 849-852.

186. Lowe, S.W., Schmitt, E.M., Smith, S.W., Osborne, B.A., Jacks, T. (1993) p53 is required for radiation-induced apoptosis in mouse thymocytes. Nature, 362, 847-849.

187. Lowe, S.W., Ruley, H.E., Jacks, T., Housman, D.E. (1993) p53-dependent apoptosis modulates the cytotoxicity of anticancer agents. Cell, 74, 957-967.

188. Kuerbitz, S.J., Plunkett, B.S., Walsh, W.V., Kastan, M.B. (1992) Wild-type p53 is a cell cycle checkpoint determinant following irradiation. Proc. Natl. Acad. Sci. U.S.A., 89, 7491-7495.

189. Kessis, T.D., Slebos, R.J., Nelson, W.G., Kastan, M.B., Plunkett, B.S., Han, S.M., Lorincz, A.T., Hedrick, L., Cho, K.R. (1993) Human papillomavirus 16 E6 expression disrupts the p53-mediated cellular response to DNA damage. Proc. Natl. Acad. Sci. U.S.A., 90, 3988-3992.

190. Gujuluva, C.N., Baek, J.-H., Shin, K.-H., Cherrick, H.M., Park, N.-H. (1994) Effect of UV-irradiation on cell cycle, viability and the expression of p53, gadd 153 and gadd 45 genes in normal and HPV-immortalized human oral keratinocytes. Oncogene, 9, $1819-1827$.

191. Hickman, E.S., Picksley, S.M., Vousden, K.H. (1994) Cells expressing HPV16E7 continue cell cycle progression following DNA damage induced p53 activation. Oncogene, 9, 2177-2181.

192. El-Deiry, W.S., Kern, S.E., Pietenpol, J.A., Kinzler, K.W., Vogelstein, B. (1992) Definition of a consensus binding site for p53. Nat. Genet., 1, 45-49.

193. Farmer, G., Bargonetti, J., Zhu, H., Friedman, P., Prywes, R., Prives, C. (1992) Wildtype p53 activates transcription in vitro. Nature, 358, 83-86. 
194. Funk, W.D., Pak, D.T., Karas, R.H., Wright, W.E., Shay, J.W. (1992) A transcriptionally active DNA-binding site for human p53 protein complexes. Mol. Cell. Biol., 12, 2866-2871.

195. Subler, M.A., Martin, D.W., Deb, S. (1992) Wild-type p53 binds to the TATA-binding protein and represses transcription. Proc. Natl. Acad. Sci. U.S.A., 89, 12028-12032.

196. Tischler, R.B., Calderwood, S.K., Coleman, C.N. Price, B.D. (1993) Increases in sequence specific DNA binding by p53 following treatment with chemotherapeutic and DNA damaging agents. Cancer Res., 53, 2212-2216.

197. Kastan, M.B., Zhan, Q., El-Deiry, W.S., Carrier, F., Jacks, T., Walsh, W.V., Plunkett, B.S., Vogelstein, B., Fornace, A.J. (1992) A mammalian cell cycle checkpoint pathway utilizing p53 and GADD45 is defective in Ataxia-Telangiectasia. Cell, 71, 587-597.

198. Zhan, Q., Carrier, F., Fornace, A.J. (1993) Induction of cellular p53 activity by DNAdamaging agents and growth arrest. Mol. Cell. Biol., 13, 4242-4250.

199. Juven, T., Barak, Y., Zauberman, A., George, D.L., Oren, M. (1993) Wild type p53 can mediate sequence-specific transactivation of an internal promotor within the $m d m 2$ gene. Oncogene, 8, 3411-3416.

200. Perry, M.E., Piette, J., Zawadzki, J.A., Harvey, D., Levine, A.J. (1993) The $m d m-2$ gene is induced in response to UV light in a p53-dependent manner. Proc. Natl. Acad. Sci. U.S.A., 90, 11623-11627.

201. Chen, C.-Y., Oliner, J.D., Zhan, Q., Fornace, A.J., Vogelstein, B., Kastan, M.B. (1994) Interactions between p53 and MDM2 in a mammalian cell cycle checkpoint pathway. Proc. Natl. Acad. Sci. U.S.A., 91, 2684-2688.

202. Price, B.D., Park, S.J. (1994) DNA damage increases the levels of mdm2 messenger RNA in wtp53 human cells. Cancer Res., 54, 896-899.

203. El-Deiry, W.S., Tokino, T., Velculescu, V.E., Levy, D.B., Parsons, R., Trent, J.M. Lin, D., Mercer, W.E., Kinzler, K.W., Vogelstein, B. (1993) WAF1, a potential mediator of p53 tumor suppression. Cell, 75, 817-825.

204. Harper, J.W., Adami, G.R., Wei, N., Keyomarsi, K., Elledge, S.J. (1993) The p21 Cdkinteracting protein Cip1 is a potent inhibitor of G1 cyclin-dependent kinases. Cell, 75, 805-816.

205. Hinds, P.W., Weinberg, R.A. (1994) Tumor suppressor genes. Curr. Opin. Genet. Dev., 4, 135-141.

206. Marx, J (1993) How p53 suppresses cell growth. Science, 262, 1644-1645

207. Momand, J., Zambetti, G.P., Olson, D.C., George, D.L. Levine, A.J. (1992) The $m d m-2$ oncogene product forms a complex with the $\mathrm{p} 53$ protein and inhibits p53-mediated transactivation. Cell, 69, 1237-1245.

208. Oliner, J.D., Pietenpol, J.A., Thiagalingam, S., Gyuris, J., Kinzler, K.W., Vogelstein, B. (1993) Oncogen MDM2 conceals the activation domain of tumour suppressor p53. Nature, 362, 857-860.

209. Selter, H., Montenarh, M. (1994) The emerging picture of p53. Int. J. Biochem., 26, 145-154.

210. Venema, J., van Hoffen, A., Karcagi, V., Natarajan, A.T., van Zeeland, A.A., Mullenders, L.H. (1991) Xeroderma pigmentosum complementation group C cells remove pyrimidine dimers selectively from the transcribed strand of active genes. Mol. Cell. Biol., 11, 4128-4134.

211. Van Schooten, F.J., Moonen, E.J.C., Rhijnsburger, E., van Agen, B., Thijssen, H.H.W., Kleinjans, J.C.S. (1994) Dermal uptake of polycyclic aromatic hydrocarbons after hairwash with coal-tar shampoo. Lancet, 344, 1505-1506.

212. Doll, R., Vessey, M.P., Beasley, R.W.R., Buckley, A.R., Fear, E.C., Fisher, R.E.W., Gammon, E.J., Gunn, W., Hughes, G.O., Lee, K., Norman-Smith, G. (1972) Mortality of gas workers- final report of a prospective study. Br. J. Ind. Med., 29, 394-406.

213. Redmond, C.K., Strobono, B.R., Cypress, R.H. (1976) Cancer experience among coke 
by-product workers. Ann. N. Y. Acad. Sci., 271, 102-115.

214. Gibbs, G.W. (1985) Mortality of aluminium reduction plant workers, 1950 through 1977. J. Occup. Med., 27, 761-770.

215. IARC (1983). Polynuclear Aromatic Compounds. Part 1. Chemical, Environment and Experimental data. IARC monograph, Vol. 32. Lyon, France: International Agency for Research on Cancer.

216. Grimmer, G. (1983) Environmental carcinogens: polycyclic aromatic hydrocarbons. Boca Raton, Florida: CRC Press.

217. Sims, P., Grover, P.L., Swaisland, A., Pal, K., Hewer, A. (1974) Metabolic activation of benzo[a]pyrene proceeds by a diol-epoxide. Nature, 252, 326-328.

218. Yang, S.K., McCourt, D.W., Roller, P.P., Gelboin, H.V. (1976) Enzymatic conversion of benzo[a]pyrene leading predominantly to the diol-epoxide $r-7, t-8$-dihydroxy-t9,10-oxy-7,8,9,10-tetrahydrobenzo[a]pyrene through a single enantiomer of $\mathrm{r}-7, \mathrm{t}-8$ dihydroxy-7,8-dihydrobenzo[a]pyrene. Proc. Natl. Acad. Sci. U.S.A., 73, 2594-2598.

219. Levin, W., Wood, A.W., Chang, R.L., Slaga, T.J., Yagi, H., Jerina, D.M., Conney, A.H. (1977) Marked differences in the tumor-initiating activity of optically pure (+)-and (-)-trans-7,8-Dihydroxy-7,8-dihydrobenzo[a]pyrene on mouse skin. Cancer Res., 37, 2721-2725.

220. Wood, A.W., Chang, R.L., Levin,W., Yagi, H., Thakker, D.R., Jerina, D.M., Conney, A.H. (1977) Differences in Mutagenicity of the optical enantiomers of the diastereomeric Benzo[a]pyrene 7,8-diol-9,10-epoxides. Biochem. Biophys. Res. Commun., 77, 1389-1396.

221. Kapitulnik, J., Wislocki, P.G., Levin, W., Yagi, H., Thakker, D.R., Akagi, H., Koreeda, M., Jerina, D.M., Conney, A.H. (1978) Marked differences in the carcinogenic activity of optically pure (+)-and (-)-trans-7,8-dihydroxy-7,8-dihydrobenzo[a]pyrene in Newborn Mice. Cancer Res., 38, 2661-2665.

222. Conney, A.H. (1982) Induction of microsomal enzymes by foreign chemicals and carcinogenesis by polycyclic aromatic hydrocarbons: G.H.A. Clowes memorial lecture. Cancer Res., 42, 4875-4917.

223. Jeffrey, A.M., Grzeskowiak, K., Weinstein, I.B., Nakanishi, K., Roller, P., Harvey, R.G. (1979) Benzo[a]pyrene-7,8-dihydrodiol 9,10-oxide adenosine and deoxyadenosine adducts: structure and stereochemistry. Science, 206, 1309-1311.

224. Meehan, T., Straub, K., Calvin, M. (1977) Benzo[a]pyrene diol epoxide covalently binds to deoxyguanosine and deoxyadenosine in DNA. Nature, 269, 725-727.

225. Straub, K.M., Meehan, T., Burlingame, A.L., Calvin, M. (1977) Identification of the major adducts formed by reaction of benz[a]pyrene diol epoxide with DNA in vitro. Proc. Natl. Acad. Sci. U.S.A., 74, 5285-5289.

226. Sage, E., Haseltine, W.A. (1984) High ratio of alkali-sensitive lesions to total DNA modification induced by benzo[a]pyrene diol epoxide. J. Biol. Chem., 259, 1109811102.

227. Brown, H., Jeffrey, A.M., Weinstein, I.B. (1979) Formation of DNA adducts in 10T1/2 Mouse Embryo Fibroblasts incubated with Benzo[a]pyrene or Dihydrodiol Oxide Derivatives. Cancer Res., 39, 1673-1677.

228. Canella, K., Peltonen, K., Dipple, A. (1991) Identification of (+) and (-) anti benzo[a]pyrene dihydrodiol epoxide-nucleic acid adducts by the ${ }^{32} \mathrm{P}$-postlabeling assay. Carcinogenesis, 12, 1109-1114.

229. Gamper, H.B., Bartholomew, J.C., Calvin, M. (1980) Mechanism of benzo[a]pyrene diol epoxide induced deoxyribonucleic acid strand scission, Biochemistry, 19, 39483956.

230. Osborne, M., Merrifield, K. (1985) Depurination of benzo[a]pyrene-diolepoxide treated DNA, Chem. Biol. Interact., 53, 183-195.

231. Moran, M.F., Ebisuzaki, K. (1991) In vivo benzo[a]pyrene diol epoxide-induced 
alkali-labile sites are not apurinic sites. Mutat. Res., 262, 79-84.

232. Osborne, M.R., Jacobs, S., Harvey, R.G., Brookes, P. (1981) Minor products from the reaction of $(+)$ and (-) benzo[a]pyrene-anti-diolepoxide with DNA. Carcinogenesis, 2, 553-558.

233. Chen, J., MacLeod, M.C., Zhao, R., Geacintov, N.E. (1993) Fluorescence HPLC methods for detecting benzo[a]pyrene-7,8-dihydrodiol 9,10-oxide-deoxyadenosine adducts in enzyme-digests of modified DNA: improved sensitivity. Carcinogenesis, 14, 1049-1051.

234. Drinkwater, N.R., Miller, E.C., Miller, J.A. (1980) Estimation of apurinic/apyrimidinc sites and phosphotriesters in dexyribonucleic acid treated with electrophylic carcinogens and mutagens. Biochemistry, 19, 5087-5092.

235. Rill, R.L., Marsch, G.A. (1990) Sequence preferences of covalent DNA binding by anti-(+)- and anti-(-)-Benzo[a]pyrene diol epoxides. Biochemistry, 29, 6050-6058.

236. Celotti, L., Ferraro, P., Biasin, M.R. (1992) Detection by fluorescence analysis of DNA unwinding and unscheduled DNA synthesis, of DNA damage and repair induced in vitro by direct-acting mutagens on human lymphocytes. Mutat. Res., 281, 17-23.

237. Gamper, H.B., Tung, A.S.C., Straub, K., Bartholomew, J.C., Calvin, M. (1977). DNA strand scission by benzo[a]pyrene diol epoxides. Science, 197, 671-674.

238. Day III, R.S., Scudiero, D., Dimattina, M. (1978) Excision repair by human fiboroblasts of DNA dàmaged by r-7,t-8-dihydroxy-t-9,10-oxy-7,8,9,10tetrahydrobenzo[a]pyrene. Mutat. Res., 50, 383-394.

239. Cerutti, P.A., Sessions, F., Hariharan, P.V., Lusby, A. (1978) Repair of DNA damage induced by benzo[a]pyrene Diol-epoxides I and II in human alveolar tumor cells. Cancer Res., 38, 2118-2124.

240. Feldman, G., Remsen, J., Wang, T.V., Cerutti, P. (1980) Formation and excision of covalent deoxyribonucleic acid adducts of benzo[a]pyrenediol epoxide I in human lung cells A 549. Biochemistry, 19, 1095-1101.

241. Van Houten, B., Masker, W.E., Carrier, W.L., Regan, J.D. (1986) Quantitation of carcinogen-induced DNA damage and repair in human cells with the UVR ABC excision nuclease from Escherichia coli. Carcinogenesis, 7, 83-87.

242. Kaufmann, W.K., Boyer, J.C., Smith, B.A., Cordeiro-Stone, M. (1985) DNA repair and replication in human fibroblasts treated with $( \pm)-r-7, t-8$-dihydroxy-t-9,10-epoxy7,8,9,10-tetrahydrobenzo[a]pyrene. Biochim. Biophys. Acta, 824, 146-151.

243. Celotti, L., Ferraro, P., Furlan, D., Zanesi, N., Pavanello, S. (1993) DNA repair in human lymphocytes treated in vitro with ( \pm )-anti- and $( \pm)$-syn-benzo[a]pyrene diolepoxide. Mutat. Res., 294, 117-126.

244. Gill, R.D., Butterworth, B.E., Nettikumara, A.N., DiGiovanni, J. (1991) Relationship between DNA adduct formation and unscheduled DNA synthesis (UDS) in cultured mouse epidermal keratinocytes. Environ. Mol. Mutagen., 18, 200-206.

245. Chen, R.-H., Maher, V.M., Brouwer, J., van de Putte, P., McCormick, J.J. (1992) Preferential repair and strand-specific repair of benzo[a]pyrene diol epoxide adducts in the HPRT gene of diploid human fibroblasts. Proc. Natl. Acad. Sci. U.S.A., 89, 5413-5417.

246. Chen, R.-H. Maher, V.M., McCormick, J.J. (1990) Effect of excision repair by diploid human fibroblasts on the kinds and locations of mutations induced by $( \pm)-7 \beta, 8 \alpha-$ dihyroxy-9 $\alpha, 10 \alpha$-epoxy-7,8,9,10-tetrahydrobenzo[a]pyrene in the coding region of the HPRT gene. Proc. Natl. Acad. Sci. U.S.A., 87, 8680-8684.

247. Andersson, B., Fält, S., Lambert, B. (1992) Strand specificity for mutations induced by (+)-anti BPDE in the hprt gene in human T-lymphocytes. Mutat. Res., 269, 129140.

248. Pero, R.W., Bryngelsson, C., Mitelman, F., Thulin, Th., Nordén, Å. (1976) High blood pressure related to carcinogen-induced unscheduled DNA synthesis, DNA carcinogen 
binding, and chromosomal aberrations in human lymphocytes. Proc. Natl. Acad. Sci. U.S.A., 73, 2496-2500.

249. Albertini, R. (1985) Somatic gene mutations in vivo as indicated by the 6thioguanine-resistant T-lymphocytes in human blood. Mutat. Res., 150, 411-422.

250. Fenech, M. (1993) The cytokinesis-block micronucleus technique and its application to genotoxicity studies in human populations. Environ. Health Perspect., 101s, 101-107

251. Hagmar, L., Brogger, A., Hansteen, I.L., Heim, S., Hogstedt, B., Knudsen, L., Lambert, B., Linnainmaa, K., Mitelman, F., Nordenson, I., et al. (1994) Cancer risk in humans predicted by increased levels of chromosomal aberrrations in lymphocytes: Nordic study group on the health risk of chromosome damage. Cancer Res., 54, 2919-2922.

252. Aboussekhra, A., Biggerstaff, M., Shivji, M.K.K., Vilpo, J.A., Moncollin, V., Podust, V.N., Protíc, M., Hübscher, U., Egly, J.-M. Wood, R.D. (1995) Mammalian DNA nucleotide excision repair reconstituted with purified protein components. Cell, 80, 859-868.

253. Savitsky, K., Bar-Shira, A., Gilad, S., Rotman, G., Ziv, Y., Vanagaite, L., Tagle, D.A., et al. (1995) A single ataxia telangiectasia gene with a product similar to PI-3 kinase. Science, 268, 1749-1753.

254. Morimoto, K., Sato-Mizuno, M., Koizumi, A. (1986) Adaptation-like response to the chemical induction of sister chromatid exchanges in human lymphocytes. Hum. Genet., 73, 81-85.

255. Shadley, J.D., Afzal, V., Wolff, S. (1987) Characterization of the adaptive response to ionizing radiation induced by low doses of $\mathrm{X}$ rays to human lymphocytes. Radiat. Res., 111, 511-517.

256. Wolff, S., Afzal, V., Wiencke, J.K., Olivieri, G., Michaeli, A. (1988) Human lymphocytes exposed to low doses of ionizing radiations become refractory to high doses of radiation as well as to chemical mutagens that induce double-strand breaks in DNA. Int. J. Radiat. Biol., 53, 39-48.

257. Bauchinger, M., Schmid, E., Braselmann, H., Nahrstedt, U. (1989) Absence of adaptive response to low-level irradiation from tritiated thymidine and X-rays in lymphocytes of two individuals examined in serial experiments. Mutat. Res., 227, 103-107.

258. Bosi, A., Olivieri, G. (1989) Variability of the adaptive response to ionizing radiations in humans. Mutat. Res., 211, 13-17.

259. Sankaranarayanan, K., van Duyn, A., Loos, M.J., Natarajan, A.T. (1989) Adaptive response of human lymphocytes to low-level radiation from radioisotopes or X-rays. Mutat. Res., 211, 7-12.

260. Schmid, E., Bauchinger, M., Nahrstedt, U. (1989) Adaptive response after Xirradiation of human lymphocytes? Mutagenesis, 4, 87-89.

261. Shadley, J.D., Wiencke, J.K. (1989) Induction of the adaptive response by X-rays is dependent on radiation intensity. Int. J. Radiat. Biol., 56, 107-118.

262. Vijayalaxmi, Burkart, W. (1989) Resistance and cross-resistance to chromosome damage in human blood lymphocytes adapted to bleomycin. Mutat. Res., 211, 1-5.

263. Youngblom, J.H., Wiencke, J.K., Wolff, S. (1989) Inhibition of the adaptive response of human lymphocytes to very low doses of ionizing radiation by the protein synthesis inhibitor cycloheximide. Mutat. Res., 227, 257-261.

264. Cortés, F., Dominguez, I., Piñero, Mateos, J.C. (1990) Adaptive response in human lymphocytes conditioned with hydrogen peroxide before irradiation with X-rays. Mutagenesis, 5, 555-557.

265. Fan, S., Vijayalaxmi, Mindek, G., Burkart, W. (1990) Adaptive response to 2 low doses of X-rays in human blood lymphocytes. Mutat. Res., 243, 53-56.

266. Kelsey, K.T., Memisoglu, A., Frenkel, D., Liber, H.L. (1991) Human lymphocytes exposed to low doses of $\mathrm{X}$-rays are less susceptible to radiation-induced mutagenesis. 
Mutat. Res., 263, 197-201.

267. Wang, Z.Q., Saigusa, S., Sasaki, M.S. (1991) Adaptive response to chromosome damage in cultured human lymphocytes primed with low doses of X-rays. Mutat. Res., 246, 179-186.

268. Wolff, S., Jostes, R., Cross, F.T., Hui, T.E., Afzal, V., Wiencke, J.K. (1991) Adaptive response of human lymphocytes for the repair of radon-induced chromosomal damage. Mutat. Res., 250, 299-306.

269. Andersson, H.C., Na Chiangmai, S. (1992) No adaptive response of chinese hamster ovary cells to low doses of ionizing radiation. Hereditas, 117, 215-222.

270. Cai, L., Liu, S.Z. (1992) Study on the mechanism of cytogenetic adaptive response induced by low dose radiation. Chin. Med. J. Engl., 105, 277-283.

271. Hain, J., Jaussi, R., Burkart, W. (1992) Lack of adaptive response to low doses of ionizing radiation in human lymphocytes from five different donors. Mutat. Res., 283, 137-144.

272. Wojcik, A., Bonk, K., Müller, W.-U., Streffer, C., Weissenborn, U., Obe, G. (1992) Absence of adaptive response to low doses of $\mathrm{X}$-rays in preimplantation embryos and spleen lymphocytes of an inbred mouse strain as compared to human peripheral lymphocytes: a cytogenetic study. Int. J. Radiat. Biol., 62, 177-186.

273. Domínguez, I., Panneerselvam, N., Escalza, P., Natarajan, A.T., Cortés, F. (1993) Adaptive response to radiation damage in human lymphocytes conditioned with hydrogen peroxide as measured by the cytokinesis-block micronucleus technique. Mutat. Res., 301, 135-141.

274. Shadley, J.D., Dai, G. (1993) Evidence that the adaptive response of human lymphocytes to ionizing radiation acts on lethal damage in nonaberrant cells. Mutat. Res., 301, 171-176.

275. Madrigal-Bujaidar, E., Cassani, M., Martínez, S., Morales, T. (1994) Adaptive response induced by mitomycin $C$ measuring the frequency of SCEs in human lymphocyte cultures. Mutat. Res., 322, 301-305.

276. Wang, Z.-Q., Auer, B., Stingl, L., Berghammer, H., Haidacher, D., Schweiger, M., Wagner, E.F. (1995) Mice lacking ADPRT and poly(ADP-ribosyl)ation develop normally but are susceptible to skin disease. Genes Dev., 9, 509-520. 


\title{
2
}

\section{Measurement by ${ }^{32} \mathrm{P}$-postlabeling of ( \pm )-anti-benzo[a]pyrene diolepoxide- $\mathrm{N}^{2}$-deoxyguanosine adduct persistence in unstimulated human peripheral blood lymphocytes}

\author{
R.H. Stierum, M.H.M. van Herwijnen, L.M. Maas, G.J. Hageman, J.C.S. Kleinjans
}

Department of Health Risk Analysis and Toxicology, University of Limburg, P.O. Box 616, 6200 MD Maastricht, The Netherlands

Based on: Mutation Research, 325, 31-37, 1994

\begin{abstract}
In order to study the relative importance for human individuals of endogenous and environmental factors on the relation between DNA damage and DNA excision repair, a method was developed for measuring quantitatively the persistence of $\mathrm{N}^{2}$-deoxyguanosine adducts formed in non-stimulated isolated human peripheral blood lymphocytes after in vitro incubation with $0.2 \mu \mathrm{M}( \pm)$ anti-BPDE, applying ${ }^{32} \mathrm{P}$-postlabeling. Total binding of radiolabeled $( \pm)$-antiBPDE to DNA and its removal has been studied previously in human peripheral blood lymphocytes, but the method presented here enables the direct investigation of repair of the main ( \pm )-anti-BPDE-DNA adduct, which is implicated in benzo[a]pyrene-induced mutagenesis. Using this method, it was found that in lymphocytes, obtained from five individuals, most $( \pm)$-anti-BPDE$\mathrm{N}^{2}$-dG adducts are removed within the first 24 hours after treatment, while interindividual differences appear to exist in both adduct formation and rate and extent of removal.
\end{abstract}

\section{Introduction}

Several factors may influence an individuals' capacity to perform DNA repair. Apart from genetic variability, as reflected by inborn disorders causing DNA repair defects (1), occupational exposure to chemicals $(2,3)$, as well as nutritional and smoking behaviour (4) may be of influence.

Benzo[a]pyrene, one of the carcinogenic $\mathrm{PAH}$, is metabolized to reactive 
quinones (5) and to certain dihydrodiol epoxides (6), from which the (+)-antibenzo[a]pyrene-7,8-dihydrodiol-9,10-epoxide ((+)-anti-BPDE) possesses the most potent genotoxic activity. In vitro (7) and in vivo (8) ( \pm )-anti-BPDE primarily forms a covalent binding between the exocyclic 2-amino position on guanine and the $\mathrm{C} 10$ position of $\mathrm{B}[\mathrm{a}] \mathrm{P}$. Formation of N7-guanine adducts as well as adenine and cytosine adducts may also occur. It is known that BPDE-guanine adduct formation may induce mutational events $(9,10)$, and it has been suggested that mainly the stable $\mathrm{N}^{2}$-dG adduct is responsible for BPDE-induced mutagenesis (11-13).

Mutagenesis induced by ( \pm )-anti-BPDE has been inversely related to repair of BPDE-dG adducts $(8,10)$. Further, it has been suggested that repair of BPDE-dG adducts may be mediated via an UvrABC-like excision repair mechanism (14), and recently, Celotti et al. (15) showed that ( \pm )-anti-BPDE treatment induces repair synthesis and rejoining of DNA strand breaks in human peripheral blood lymphocytes, indicating that ( \pm )-anti-BPDE DNA adducts induce excision repair related processes in human cells in vitro. The same study also showed the wide range of inter-individual variability in repair of alkali-labile sites and unscheduled DNA synthesis induced by direct-acting mutagens.

To study the relative importance of endogenous and environmental factors on the relation between individual differences in DNA excision repair and DNA damage, quantitative assessment of excision repair is required. Therefore, a protocol was developed for measuring the persistence of the $\mathrm{N}^{2}$-deoxyguanosine DNA adducts, formed in non-stimulated isolated human peripheral lymphocytes after in vitro incubation with ( \pm )- $7 \beta, 8 \alpha$-dihydroxy- $9 \alpha, 10 \alpha$-epoxy$7,8,9,10$-tetrahydrobenzo[a]pyrene (( \pm$)$-anti-BPDE), using the nuclease P1 enhanced ${ }^{32} \mathrm{P}$ postlabeling method of Reddy and Randerath (16). Although binding of radiolabeled $( \pm$ )-anti-BPDE to DNA in human peripheral blood lymphocytes and its subsequent removal has been reported previously $(4,17)$, the use of the method presented here, enables the study of repair kinetics of the main ( \pm )-anti-BPDE-DNA adduct, involved in benzo[a]pyrene-induced mutagenesis, namely ( \pm )-anti-BPDE- $\mathrm{N}^{2}$-dG.

\section{Materials and methods}

$100 \mathrm{ml}$ of venous heparinized blood was collected from 5 healthy, non-smoking volunteers. Lymphocytes were immediately isolated using Lymphoprep (Nycomed), and washed with PBS. Pellets were dissolved in RPMI 1640 culture medium (Gibco) and 10-15 × $10^{6}$ lymphocytes were transferred to culture tubes. Medium was adjusted to a volume of exactly $5 \mathrm{ml}$. ( \pm )-anti-BPDE was obtained from Midwest Research Institute USA, dissolved in anhydrous DMSO and stored frozen prior to use. $( \pm)$-anti-BPDE was quickly added to the cultures to a final concentration of $0.2 \mu \mathrm{M}$. From each donor, two cultures were set up to serve as 
DMSO solvent control (final concentration $0.1 \%$ ), for determination of putative endogenous ( \pm )-anti-BPDE- $\mathrm{N}^{2}-\mathrm{dG}$ adduct levels. Suspensions were mixed by swirling and were subsequently incubated for 15 minutes at $37^{\circ} \mathrm{C}$. Within 1 minute after incubation, cells were centrifuged for 10 minutes at $400 \mathrm{~g}$ and washed once with PBS. For determination of adduct levels, DNA from cells was digested with proteinase $\mathrm{K}$, extracted once with phenol : chloroform : isoamyl alcohol $25: 24: 1(\mathrm{v} / \mathrm{v} / \mathrm{v})$, once with chloroform : isoamyl alcohol $24: 1(\mathrm{v} / \mathrm{v})$ and subsequently precipitated by the addition of $1 / 30$ volume of $3 \mathrm{M}$ sodium acetate $\mathrm{pH} 5.2$ and an equal volume of ice-cold isopropanol. DNA was washed with cold $70 \%$ ethanol and dissolved in $2 \mathrm{mM}$ Tris- $\mathrm{HCl} \mathrm{pH}$ 7.4. DNA concentrations of sheared homogeneous, non-viscous samples were measured spectrophotometrically, using a Beckman DU-64 spectrophotometer, according to Warburg and Christian (18). Variation in DNA concentration, as determined from duplicate dilutions from one DNA sample was always less than $3 \%$.

For determination of adduct levels at various time points after ( \pm )-anti-BPDE incubation, exposed cells were suspended in RPMI 1640 medium supplemented with $100 \mu \mathrm{g} / \mathrm{ml}$ streptomycin, $100 \mathrm{U} / \mathrm{ml}$ penicillin, $5 \mathrm{mM}$ L-glutamine, $50 \mathrm{U} / \mathrm{ml}$ heparin and $10 \%$ foetal calf serum (FCS) (all from Gibco). At the respective time points $(4,7$ or $16,24,48$ or 52,72 hours) after treatment with ( \pm -anti-BPDE, DNA was isolated as described above. Cytotoxicity was determined at these time points, using the trypan blue exclusion technique.

The level of $( \pm)$-anti-BPDE- $\mathrm{N}^{2}$-deoxyguanosine adducts was determined according to procedures developed by Reddy and Randerath (1986). Approximately $5 \mu \mathrm{g}$ DNA was digested for 3 hours at $37{ }^{\circ} \mathrm{C}$ with $200 \mathrm{mU}$ micrococcal nuclease and $2.8 \mathrm{mU}$ spleen phosphodiesterase in a total volume of $5 \mu \mathrm{l}$ containing $20 \mathrm{mM}$ sodium succinate and $10 \mathrm{mM} \mathrm{CaCl} 2$ with $\mathrm{pH}$ 6.0. Subsequently, samples were digested with $6.25 \mu \mathrm{g}$ nuclease P1 ( $\pm 6.25 \mathrm{U}$ 3'phosphomonoesterase activity) in a total volume of $10 \mu \mathrm{l}$, containing $0.03 \mathrm{mM}$ $\mathrm{ZnCl}_{2}$ and $37.5 \mathrm{mM}$ sodiumacetate $\mathrm{pH} 5.0$, for 40 minutes at $37^{\circ} \mathrm{C}$. and then 2.5 $\mu \mathrm{l}$ of $0.5 \mathrm{M}$ Tris Base was added. The DNA digest, containing the deoxyribonucleoside 3'-monophosphates was incubated with $50 \mu \mathrm{Ci}\left[\gamma^{-32} \mathrm{P}\right] \mathrm{ATP}$ (synthesized in our laboratory, using carrier free ${ }^{32} \mathrm{P}$, spec. act. $>3000 \mathrm{Ci} / \mathrm{mmol}$ ) and 5 units of T4 polynucleotide kinase to yield [5'-32P]-deoxyribonucleosides 3',5'-biphosphates. Termination of the reaction was performed by incubating the mixture during 30 minutes at $37^{\circ} \mathrm{C}$ with $15 \mathrm{mU}$ potato apyrase. All enzymes were from Boehringer Mannheim. 32P-labeled adducts were purified and resolved on polyethyleneimine-cellulose TLC sheets (Machery-Nagel, Düren, Germany.) Chromatography was performed using the following solvents: Direction (D) 1, $1.0 \mathrm{M}$ sodium phosphate, $\mathrm{pH}$ 6.0; D2, $3.5 \mathrm{M}$ lithium formate, 8.5 $\mathrm{M}$ urea, $\mathrm{pH}$ 3.5; D3 $0.8 \mathrm{M} \mathrm{LiCl}, 0.5 \mathrm{M}$ Tris- $\mathrm{HCl} 8.5 \mathrm{M}$ urea, $\mathrm{pH}$ 8.0, D4, $1.7 \mathrm{M}$ sodium phosphate, $\mathrm{pH}$ 6.0. Chromatograms were visualized by autoradiography at $-80^{\circ} \mathrm{C}$. One-dimensional TLC of [5'-32 P]deoxyribonucleosides $3^{\prime}, 5^{\prime}$ biphosphates (obtained after enzymatic hydrolysis and ${ }^{32} \mathrm{P}$-postlabeling) with 0.12 
$\mathrm{M} \mathrm{NaH}{ }_{2} \mathrm{PO}_{4} \mathrm{pH} 6.0$ (19), of DNA samples extracted from untreated, unstimulated human peripheral blood lymphocytes, indicated that RNA contamination was absent since only deoxyribonucleoside derivatives were detected. Adduct levels were determined by excising areas of the chromatograms and radioactivity was measured by liquid scintillation counting.

For each experiment, $\left[{ }^{3} \mathrm{H}\right]( \pm)$-anti-BPDE modified DNA standards with modification levels of respectively 1 adduct $/ 10^{7}, 10^{8}$ and $10^{9}$ nucleotides were included in the procedure described above (20). Experiments from our laboratory, using the standard with modification level of 1 adduct per $10^{7}$ nucleotides, indicate actual recoveries of $80-100 \%$ (determined as RAL (nuclease $\mathrm{P} 1 /$ modification level $\left[{ }^{3} \mathrm{H}\right]( \pm)$-anti-BPDE modified DNA standard $\left.* 100\right)$. Linear calibration curves were prepared from these standards by plotting the number of DPM, recovered within the area containing the standard ( \pm )-anti-BPDE- $\mathrm{N}^{2}-\mathrm{dG}$ adduct vs. modification level. The number of DPM, recovered within the area containing the $( \pm)$-anti-BPDE- $\mathrm{N}^{2}-\mathrm{dG}$ adducts from samples, was directly related to this calibration curve, whereafter the number of adducts/nucleotide was calculated by correction for differences in DNA amounts between standards and samples, assuming that $1 \mu \mathrm{g}$ DNA is equivalent to $3240 \mathrm{pmol} \mathrm{dNp}$. Adduct spots, determined in DNA samples obtained from DMSO treated lymphocytes, chromatographing at a similar position, relative to the origin as the $( \pm)$-antiBPDE- $\mathrm{N}^{2}-\mathrm{dG}$ standards, were termed putative endogenous ( \pm -anti-BPDE- $\mathrm{N}^{2}$ $\mathrm{dG}$ adducts, and directly related to the ( \pm )-anti-BPDE- $\mathrm{N}^{2}-\mathrm{dG}$ standards. Average intra- and interassay (day-to-day) variations in the determination of $( \pm$ )-antiBPDE- $\mathrm{N}^{2}$-dG adduct levels in DNA samples were respectively 17.8 and $8.9 \%$.

\section{Results and discussion}

Figure 2.1 shows chromatograms of DNA samples obtained from lymphocytes of donor 2 at various time intervals after in vitro incubation with ( \pm )-anti-BPDE. After a 15 minutes incubation period ( $t=0$ hours) of freshly isolated human peripheral blood lymphocytes with $0.2 \mu \mathrm{M}( \pm)$-anti-BPDE, a major spot is visible, chromatographing at a similar position relative to the origin as the $( \pm)$-antiBPDE-N2 ${ }^{2}-\mathrm{dG}$ standard. The intensity of the ( \pm )-anti-BPDE- $\mathrm{N}^{2}-\mathrm{dG}$ spot decreases with time, indicating removal of $\left( \pm\right.$ )-anti-BPDE- $\mathrm{N}^{2}$-deoxyguanosine adducts.

In Figure 2.2, the level of ( \pm -anti-BPDE- $\mathrm{N}^{2}$-dG adducts, expressed as adducts $/ 10^{9}$ nucleotides, at different time intervals after exposure of lymphocytes to $0.2 \mu \mathrm{M}( \pm)$-anti-BPDE in vitro is shown for 5 donors. In most resting lymphocyte cultures, almost all adducts are removed within 4 to 7 hours, followed by a period in which it seems that adduct removal is absent or slow. Whether a real second slow repair phase in the process of ( \pm )-anti-BPDE- $\mathrm{N}^{2}-\mathrm{dG}$ adduct removal actually occurs in these cells is unknown. No cell death was observed at different time intervals after ( \pm )-anti-BPDE exposure of PBLs, 


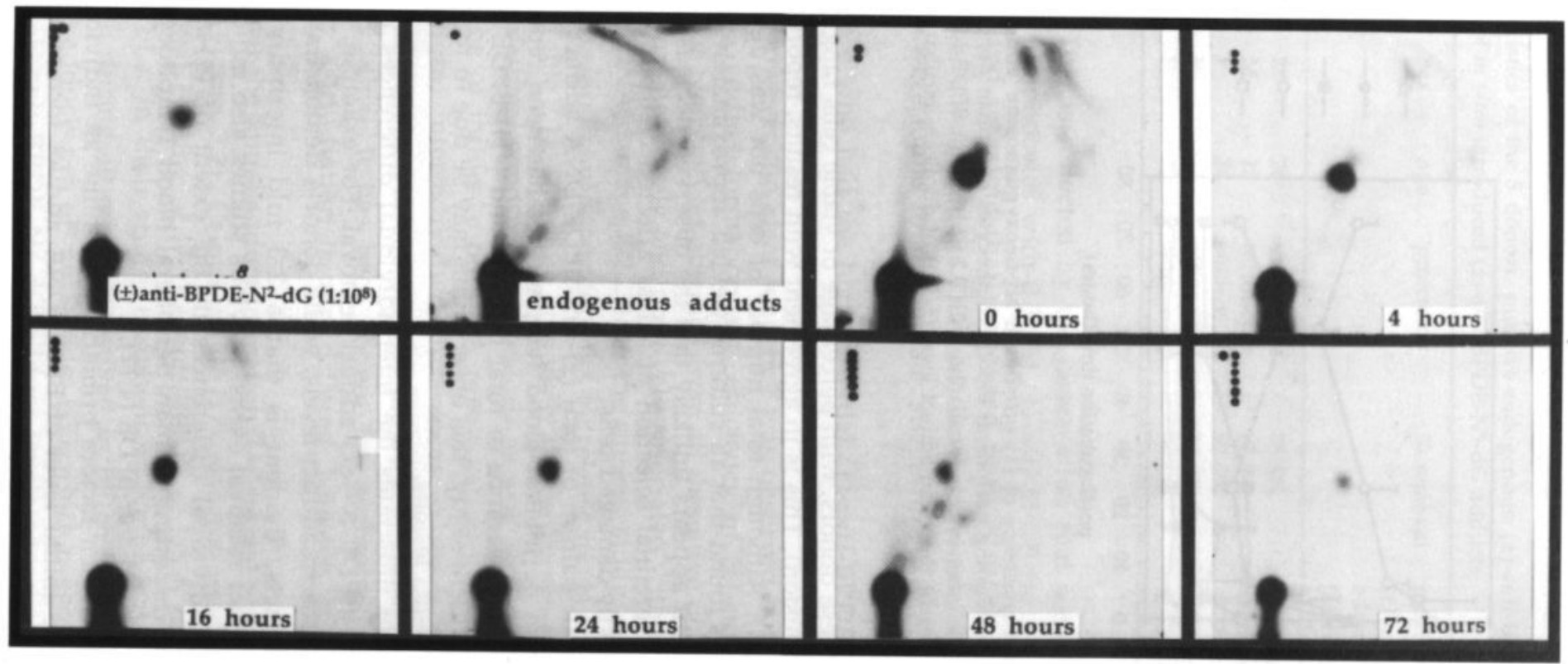

Figure 2.1. Chromatograms of ( \pm )-anti-BPDE- $\mathrm{N}^{2}$-dG adduct standard ( 1 adduct per $10^{8}$ nucleotides) and DNA samples obtained from resting peripheral blood lymphocytes of donor 2 at various time intervals, after in vitro incubation with $0.2 \mu \mathrm{M}$ ( \pm )-anti-BPDE during 15 minutes (or $\mathrm{DMSO}$, as solvent control). Autoradiography was performed at $-80^{\circ} \mathrm{C}$ during 70 hours, using Amersham Hyperfilm ${ }^{\mathrm{TM}}$-MP X-ray film in combination with Kodak X-omatic intensifying screens. 


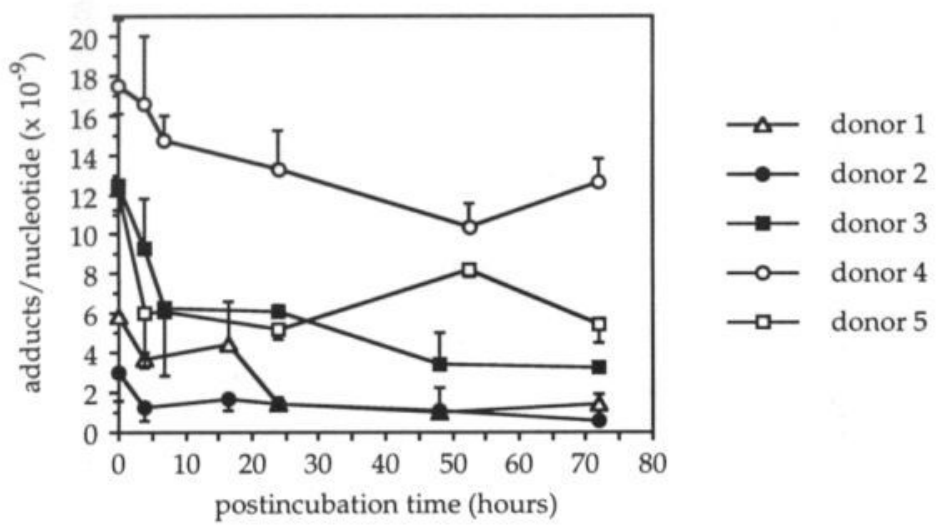

Figure 2.2. Persistence of ( \pm -) anti-BPDE- $\mathrm{N}^{2}$-deoxyguanosine adducts in DNA obtained from resting peripheral blood lymphocytes of human donors at various time intervals, after in vitro incubation with $0.2 \mu \mathrm{M}( \pm)$-anti-BPDE for 15 minutes. Results represent the mean adduct level $( \pm S D$ ) of duplicate incubations, for each experiment.

obtained from these donors, with percentage of viable cells ranging from $90-100 \%$ (trypan blue exclusion). This is in agreement with results, reported previously by Rankin et al. (21). Although total number of cells not was determined at each time point, it was found that all cultures yielded approximately equal amounts of DNA. Therefore, it appears unlikely that the observed decrease in adduct levels is related to preferential selection of a less affected cell population, surviving after lysis of heavily damaged cells.

A similar repair pattern of total ( \pm )-anti-BPDE-DNA adduct removal in nonstimulated human peripheral blood lymphocytes has been reported previously, measuring the disappearance of total DNA bound [ $\left.{ }^{3} \mathrm{H}\right]-$ BPDE (4). However, in contrast to the present study, this observation may be due to removal of not only $( \pm)$-anti-BPDE- $\mathrm{N}^{2}$-dG lesions.

Figure 2.2 also illustrates the interindividual differences in both rate and extent of ( \pm )-anti-BPDE- $\mathrm{N}^{2}$-dG adduct removal. For example, donor 1 shows a very rapid decrease in adduct levels, while donor 4 demonstrates a more slowly removal of adducts. Evident is that a 2-3 fold interindividual variety in effectivity of adduct removal exists. Previous studies also indicate the existence of similar interindividual differences in the extent of ( \pm )-anti-BPDE-DNA adduct removal in resting human peripheral blood lymphocytes after in vitro treatment with $\left[{ }^{3} \mathrm{H}\right]( \pm)$-anti-BPDE $(4,17)$.

It is not clear which factors primarily determine an individuals' capacity of DNA repair. The initial level of BPDE-DNA adduct formation may influence repair kinetics indirectly, possibly via interference with mRNA expression of 
Table 2.1. Characteristics of the 5 donors, putative endogenous ( \pm )-anti-BPDE- $\mathrm{N}^{2}-\mathrm{dG}$ adduct levels, and removal of in vitro introduced $( \pm)$-anti-BPDE- ${ }^{2}-\mathrm{dG}$ adducts.

\begin{tabular}{lllllll}
\hline donor & $\begin{array}{l}\text { smoker/ } \\
\text { non-smoker } \\
\text { (S/NS) }\end{array}$ & sex & age & profession & \% removal & $\begin{array}{l}\text { putative endogenous } \\
( \pm) \text {-anti-BPDE- }{ }^{2} \text {-dG } \\
\text { adduct level } \\
\text { (adducts } / 10^{9} \text { nucleotides) }\end{array}$ \\
\hline 1 & NS & M & 24 & technician & $75.5 \%$ & not detectable \\
2 & NS & M & 25 & technician & $52.8 \%$ & not detectable \\
3 & NS & F & 24 & student & $52.0 \%$ & $0.27 \pm 0.24$ \\
4 & NS & F & 23 & office employee & $24.0 \%$ & $17.80 \pm 6.80$ \\
5 & NS & F & 22 & student & $58.1 \%$ & $0.12 \pm 0.05$ \\
\hline
\end{tabular}

repair enzymes. This is reflected by the observation that treatment of human peripheral blood lymphocytes with $0.3 \mu \mathrm{M}( \pm)$-anti-BPDE for 1 hour resulted in strand breakage and resealing that proceeded until 20 hours after ending of exposure; at higher concentrations $(1.2 \mu \mathrm{M})$ however, resealing ceased after 4 hours and breaks were found to accumulate, suggesting saturation of the repair system (17).

Further, donor 4 who had the highest initial $( \pm)$-anti-BPDE-N ${ }^{2}-\mathrm{dG}$ adduct level, showed the less efficient removal of in vitro introduced ( \pm )-anti-BPDE$\mathrm{N}^{2}$-dG adducts. However, no clear tendency was observed between initial $( \pm)$ anti-BPDE- $\mathrm{N}^{2}-\mathrm{dG}$ adduct formation and efficiency of $( \pm)$-anti-BPDE- $\mathrm{N}^{2}-\mathrm{dG}$ adduct removal, for lymphocytes obtained from all these five donors.

Age has also been negatively and positively associated with repair activity of different kinds of DNA damage $(22,23)$. In the present study, age hardly varied between the donors, and could therefore not be related to ( \pm )-anti-BPDE- $\mathrm{N}^{2}-\mathrm{dG}$ adduct removal (Table 2.1). Therefore, it is likely that unknown factors, related to for example occupational exposure to chemicals as well as dietary and drinking habits may also be of influence on DNA repair capacity in these individuals $(24,25)$. Furthermore, interindividual differences in susceptibility to DNA damaging agents of lymphocytic subsets may attribute to the observed differences in repair activity, since it has been shown for example that induction of micronuclei after $\mathrm{X}$-irradiation in vitro differed between subpopulations of lymphocytes (26).

It was found that the initial adduct formation ( $t=0$ hours) varies between the 5 donors studied (Figure 2.2). Celotti et al. (17) also reported interindividual differences in initial binding of $\left[{ }^{3} \mathrm{H}\right]( \pm)$-anti-BPDE to DNA of in vitro treated resting human PBLs. In their study, treatment of lymphocytes with $0.33 \mu \mathrm{M}$ $\left[{ }^{3} \mathrm{H}\right]( \pm)$-anti-BPDE during 40 minutes resulted in BPDE-DNA adduct levels of approximately 9.3 adducts per $10^{6}$ nucleotides (17), which is about 100-1000 times higher than the $( \pm)$-anti-BPDE- $\mathrm{N}^{2}-\mathrm{dG}$ adduct levels observed in the present 
study. It is unlikely that this discrepancy is specifically related to the methods used, since most of total DNA-bound radiolabel was related to the presence of $( \pm)$-anti-BPDE- $\mathrm{N}^{2}$-dG adducts. Furthermore, it seems unlikely that differences in duration of $( \pm)$-anti-BPDE treatment ( 40 minutes vs. 15 minutes in this study) accounts solely for this discrepancy, since it has been shown in rodent cells, that maximum DNA binding of $\left[{ }^{3} \mathrm{H}\right]( \pm)$-anti-BPDE was already accomplished after 15 minutes of exposure. (27). Thus, it remains unclear what caused the differences in initial ( \pm )-anti-BPDE- $\mathrm{N}^{2}$-dG levels, observed between these studies.

In the present study, in donor 4, a putative endogenous ( \pm )-anti-BPDE- $\mathrm{N}^{2}$-dG adduct level of $17.7 \pm 6.8$ adducts per $10^{9}$ nucleotides was found, which might reflect a relatively low activity of detoxification pathways for ( \pm -anti-BPDE in vivo. Alternatively, since this donor also showed the less effective removal of $( \pm)$-anti-BPDE- $\mathrm{N}^{2}-\mathrm{dG}$ adducts after in vitro incubation with ( \pm )-anti-BPDE, the presence of these putative endogenous adducts could be due to inefficient repair in vivo. In contrast, individuals with undetectable putative endogenous adduct levels in vivo, showed effective ( \pm )-anti-BPDE- ${ }^{2}$-dG removal (donor 1 and 2; resp. $75.5 \%$ and $52.8 \%$ ) in vitro. However, the presence of high levels of putative endogenous ( \pm )-anti-BPDE- $\mathrm{N}^{2}-\mathrm{dG}$ levels (donor 4) may interfere with quantification of the in vitro introduced $\left( \pm\right.$ )-anti-BPDE- ${ }^{2}-\mathrm{dG}$ adducts (see Table 2.1 and Figure 2.2), since it is otherwise unexplainable why in vitro exposure to ( \pm )-anti-BPDE of lymphocytes, obtained from donor 4 would not result in additional formation of BPDE DNA adducts.

Since measurement of PAH-DNA adduct levels by ${ }^{32} \mathrm{P}$-postlabeling seems to be useful in monitoring exogenous exposure to $\mathrm{PAH}$, related to occupation, diet, smoking behaviour as well as environmental factors (28), the protocol described in the present study may also enable evaluation of the effects of these factors on the relation between individual differences in endogenous DNA damage and DNA excision repair, induced in vitro.

In conclusion, it is demonstrated that the use of ${ }^{32} \mathrm{P}$-postlabeling after in vitro incubation of resting human peripheral blood lymphocytes with ( \pm -)anti-BPDE, allows for the accurate determination of repair of the BPDE-DNA adduct, generally hypothesized to be involved in BPDE-induced mutagenesis (11-13), namely the ( \pm )-anti-BPDE-N ${ }^{2}$-dG adduct. Most ( \pm -anti-BPDE- ${ }^{2}$-dG adducts appear to be removed within the first 24 hours after exposure and considerable interindividual differences exist in both adduct formation, and rate and extent of adduct removal. Using the method described here, it will be possible to determine the implications of exogenous and inborn factors on interindividual differences in DNA damage and repair.

\section{Acknowledgements}

The authors wish to thank Dr. F.J. van Schooten for kindly providing $\left[{ }^{3} \mathrm{H}\right]( \pm)$ anti-BPDE modified DNA standards and helpful discussions. 


\section{References}

1. Cleaver, J.E., Thomas, G.H. (1993) Clinical syndromes associated with DNA repair deficiency and enhanced sun sensitivity. Arch. Dermatol., 129, 348-350.

2. Oesch, F., Klein, S. (1992) Relevance of environmental alkylating agents to repair protein $\mathrm{O}^{6}$-alkylguanine DNA alkyltransferase: Determination of individual and collective repair capacities of $\mathrm{O}^{6}$-methylguanine. Cancer Res., 52, 1801-1803.

3. Pero, R.W., Bryngelsson, T., Widegren, B., Högstedt, B., Welinder, H. (1982) A reduced capacity for unscheduled DNA synthesis in lymphocytes from individuals exposed to propylene oxide and ethylene oxide. Mutat. Res., 104, 193-200.

4. Oesch, F., Aulmann, W., Platt, K.L., Doerjer, G. (1987) Individual differences in DNA repair capacities in man. Arch. Toxicol. Suppl., 10, 172-179.

5. Rogan, E.G., Ramakrishna, N.V.S., Higginbotham, S., Cavalieri, E.L., Jeong, H., Jankowiak, R., Small, G.J. (1990) Identification and quantitation of 7-(Benzo[a]pyren6-yl)guanine in the urine and feces of rats treated with benzo[a]pyrene. Chem. Res. Toxicol., 3, 441-444.

6. Dipple, A., Moschel, R.C., Bigger, C.A.H. (1984) Polynuclear aromatic hydrocarbons. In: Searle, C.E. (eds.), Chemical Carcinogens. Am. Chem. Soc., Vol 1, Second edition, Washington DC: pp. 41-163.

7. Weinstein, I.B., Jeffrey, A.M., Jenette, K.W., Blobstein, S.H., Harvey, R.G., Harris, C., Autrup, H., Kasai, H., Miura, I., Nakanishi, K. (1976) Benzo[a]pyrene diol epoxides as intermediates in nucleic acid binding in vitro and in vivo. Science, 193, 592-595.

8. Yang, Li.L., Maher, V.M., McCormick, J.J. (1980) Error-free excision of the cytotoxic, mutagenic $\mathrm{N}^{2}$-deoxyguanosine DNA adduct formed in human fibroblasts by $( \pm)$ $7 \beta, 8 \alpha$-dihydroxy-9 $\alpha, 10 \alpha$-epoxy-7,8,9,10-tetrahydrobenzo[a]pyrene. Proc. Natl. Acad. Sci U.S.A., 77, 5933-5937.

9. Norimura, T., Maher, V.M., McCormick, J.J. (1990) Cytotoxic and mutagenic effect of UV, ethylnitrosourea and ( \pm )- $7 \beta, 8 \alpha$-dihydroxy- $9 \alpha, 10 \alpha$-epoxy-7,8,9,10 tetrahydrobenzo[a]-pyrene in diploid human $\mathrm{T}$ lymphocytes in culture: comparison with fibroblasts. Mutagenesis, 5, 447-451.

10. Yang, Li. L., Maher, V.M., McCormick, J.J. (1982) Relationship between excision repair and the cytotoxic and mutagenic effect of the 'anti' 7,8-diol-9,10-epoxide of benzo[a]pyrene in human cells. Mutat. Res., 94, 435-447.

11. Yang, J.-L., Maher, V.M., McCormick, J.J. (1987) Kinds of mutations formed when a shuttle vector containing adducts of $( \pm)-7 \beta, 8 \alpha$-dihyroxy- $9 \alpha, 10 \alpha$-epoxy-7,8,9,10tetrahydrobenzo[a]pyrene replicates in human cells. Proc. Natl. Acad. Sci. U.S.A., 84, 3787-3791.

12. Yang, J-L., Chen, R-H., Maher, V.M., McCormick, J.J. (1991) Kinds and location of mutations induced by $( \pm)-7 \beta, 8 \alpha$-dihydroxy- $9 \alpha, 10 \alpha$-epoxy-7,8,9,10-tetrahydrobenzo[a]pyrene in the coding region of the hypoxanthine (guanine) phosphoribosyltransferase gene in diploid human fibroblasts. Carcinogenesis, 12, 7175.

13. Carothers, A.M., Grunberger, D. (1990) DNA base changes in benzo[a]pyrene diol epoxide-induced dihydrofolate reductase mutants of Chinese hamster ovary cells. Carcinogenesis, 11, 189-192.

14. Van Houten, B., Masker, W.E., Carrier, W.L., Regan, J.D. (1986) Quantitation of carcinogen-induced DNA damage and repair in human cells with the UVR ABC excision nuclease from Echerichia coli. Carcinogenesis, 7, 83-87.

15. Celotti, L., Ferraro, P., Biasin, M.R. (1992) Detection by fluorescence analysis of DNA unwinding and unscheduled DNA synthesis, of DNA damage and repair induced in vitro by direct-acting mutagens on human lymphocytes. Mutat. Res., 281, 17-23.

16. Reddy, M.V., Randerath, K. (1986) Nuclease P1-mediated enhancement of sensitivity 
of ${ }^{32} \mathrm{P}$-postlabeling test for structural diverse DNA adducts. Carcinogenesis, 7, 15431551.

17. Celotti, L., Ferraro, P., Furlan, D., Zanesi, N., Pavanello, S. (1993) DNA repair in human lymphocytes treated in vitro with ( \pm )-anti- and $( \pm)$-syn-benzo[a]pyrene diolepoxide. Mutat. Res., 294, 117-126.

18. Warburg, O., Christian, W. (1942) Isolierung und kristallisation des gärungsfermente enolase. Biochem. Z., 310, 348-421.

19. Lutgerink, J.T., van den Akker, E., Smeets, I., Pachen, D., van Dijk, P., Aubry, J.-M., Joenje, H., Lafleur, M.V.M., Retèl, J. (1992) Interaction of singlet oxygen with DNA and biological consequences. Mutat. Res., 275, 377-386.

20. Van Schooten, F.J., Kriek, E., Steenwinkel, M.-J.S.T., Noteborn, H.P.J.M., Hillebrand, M.J.X., Van Leeuwen, F.E. (1987) The binding efficiency of polyclonal and monoclonal antibodies to DNA modified with benzo[a]pyrene diol epoxide is dependent on the level of modification. Implications for quantitation of benzo[a]pyrene-DNA adducts in vivo. Carcinogenesis, 8, 1263-1269.

21. Rankin, P.W., Jacobson, M.K., Mitchell, V.R., Busbee, D.L. (1980) Reduction of nicotinamide adenine dinucleotide levels by ultimate carcinogens in human lymphocytes. Cancer Res., 40, 1803-1807.

22. Wei, Q., Matanoski, G.M., Farmer, E.R., Hedayati, M.A., Grossman, L. (1993) DNA repair and aging in basal cell carcinoma: A molecular epidemiology study. Proc. Natl. Acad. Sci. U.S.A., 90, 1614-1618.

23. Pero, R.W., Östlund, C. (1980) Direct comparison, in human resting lymphocytes, of the inter-individual variations in unscheduled DNA synthesis induced by $N$-acetoxy2-acetylaminofluorene and ultraviolet irradiation. Mutat. Res., 73, 349-361.

24. Topinka, J., Binková, B., Sram, R.J., Fojtíková, I. (1991) DNA-repair capacity and lipid peroxidation in chronic alcoholics. Mutat. Res., 263, 133-136.

25. Boothman, D.A., Schlegel, R., Pardee, A.B. (1988) Anti-carcinogenic potential of DNA-repair modulators. Mutat. Res., 202, 393-411.

26. Wuttke, K., Streffer, C., Müller, W.U. (1993) Radiation induced micronuclei in subpopulations of human lymphocytes. Mutat. Res., 286, 181-188.

27. Krolewski, B., Little, J.B., Reynolds, R.J. (1988) Effect of duration of exposure to benzo[a]pyrene diol-epoxide on neoplastic transformation, mutagenesis, cytotoxicity, and total covalent binding to DNA of rodent cells. Teratog. Carcinog. Mutagen., 8, 127-136.

28. dell' Omo, M., Lauwerys, R.R. (1993) Adducts to macromolecules in the biological monitoring of workers exposed to polycyclic aromatic hydrocarbons. Crit. Rev. Toxicol., 23, 111-126. 
Increased poly(ADP-ribose) polymerase activity during repair of ( \pm )-anti-benzo[a]pyrene diolepoxide-induced DNA damage in human peripheral blood lymphocytes in vitro

\author{
R.H. Stierum, M.H.M. van Herwijnen, G.J. Hageman and J.C.S. Kleinjans
}

Department of Health Risk Analysis and Toxicology, University of Limburg, P.O. Box 616, 6200 MD Maastricht, The Netherlands

Based on: Carcinogenesis, 15, 745-751, 1994

\title{
Abstract
}

Poly(ADP-ribose) polymerase, catalyzing the formation of poly(ADP-ribose) polymers is an enzyme involved in cell proliferation, differentiation and transformation as well as in recovery from DNA damage. Poly(ADP-ribose) polymers are rapidly synthesized from the ADP-ribose moieties from intracellular $\mathrm{NAD}^{+}$, which, as a consequence, is depleted. It has been shown that DNA strand breaks are required for enzyme activation and it is suggested that one of the functions of poly(ADP-ribosylation) is to improve accessibility of damaged sites to other DNA repair enzymes. The aim of this study was to investigate whether poly(ADP-ribosylation) is involved in repair of $( \pm)-7 \beta, 8 \alpha$ dihydroxy- $9 \alpha, 10 \alpha$-epoxy-7,8,9,10-tetrahydrobenzo[a]-pyrene (( \pm -anti-BPDE) induced DNA damage in human lymphocytes in vitro. Results show that ( \pm )anti-BPDE is capable of inducing poly(ADP-ribosylation), $\mathrm{NAD}^{+}$depletion and inhibition of proliferation in PHA-stimulated human peripheral blood lymphocytes. Also, repair of $( \pm)$-anti-BPDE-induced DNA damage was confirmed by both unscheduled DNA synthesis and ( \pm -anti-BPDE- $\mathrm{N}^{2}-\mathrm{dG}$ adduct removal. Based on these findings, it is concluded that poly(ADPribosylation) may be involved in ( \pm )-anti-BPDE-induced DNA repair in these cells. In addition, these results confirm the possible relation between poly(ADPribosylation), $\mathrm{NAD}^{+}$depletion and inhibition of proliferation, after induction of DNA damage. 


\section{Introduction}

The biological functions of the intranuclear polyadenosine diphosphate-ribose polymer, are still not fully understood. It has been implicated in various processes like cell proliferation, differentiation, transformation and recovery from DNA damage $(1,2)$. Synthesis of this polymer is catalyzed by the enzyme poly(ADP-ribose) polymerase [NAD ${ }^{+}$ADP-ribosyltransferase, EC 2.4.2.30] (abbreviation PADPRT), a zinc-binding nuclear enzyme, which transfers the ADP-ribose moieties from nicotinamide adenine dinucleotide in a proximal or distal mode to the ongrowing chains of the poly(ADP-ribose) polymer. The ADPribose moieties are polymerized through ribose $\alpha\left(1^{\prime}-2^{\prime}\right)$ ribose bonds in a linear and branched structure $(3,4)$. It is assumed that polymer synthesis is involved in DNA damage and DNA excision repair, since DNA strand breaks are required for enzyme activity $(5,6,7)$. Next to the enzyme itself, histones act as main acceptor proteins for poly(ADP-ribose) molecules $(1,2)$.

It has been postulated that the accessibility of damaged DNA for repair enzymes is transiently improved through rapid automodification of PADPRT upon activation by DNA single or double strand breaks, followed by formation of poly(ADP-ribose) polymers on core and linker histones. The resulting dissociation of the histone-DNA complexes with local decondensation of the chromatin, enabling repair enzymes to perform repair synthesis and ligation at the damaged site. Subsequently, the poly(ADP-ribose) polymers are rapidly degraded by another enzyme, the poly(ADP-ribose) glycohydrolase, enabling reassociation of the histones to the DNA, leading to recondensation of the chromatin $(8,9)$.

Alternatively, direct modification of repair enzymes, e.g. stimulation of ligase II activity, has been proposed (10), but experiments concerning the direct action of PADPRT on ligase II yielded contradictory results $(11,12)$. Thirdly, the induction of poly(ADP-ribose) polymer synthesis after severe DNA damage may represent a cellular suicide mechanism. Cells subjected to DNA damage showed decreased intracellular NAD ${ }^{+}$and ATP levels $(6,7,13)$, which was found to be related to cell lysis (7).

Benzo[a]pyrene, a full environmental carcinogen, is metabolized by cytochrome P450 dependent monooxygenases and epoxide hydrolase to reactive diolepoxides, as well as via one-electron oxidation to radical cations (14). In vitro and in vivo, (+)-anti-benzo[a]pyrene-7,8-dihydrodiol-9,10-epoxide mainly results in the formation of an adduct between the $\mathrm{N}^{2}$ position of guanine and the $\mathrm{C} 10$ position of $\mathrm{B}[\mathrm{a}] \mathrm{P}((+)-$ anti-BPDE-dG). After treatment of cells with $( \pm)$-anti-BPDE $(( \pm)-7 \beta, 8 \alpha$-dihydroxy- $9 \alpha, 10 \alpha$-epoxy-7,8,9,10-tetrahydrobenzo[a]pyrene), mutational events occur, mainly GC---> TA transversions. (15-18).

Repair of BPDE-DNA damage in mammalian cells appears to be mediated through excision repair mechanisms. Recently, ( \pm -anti-BPDE was shown to 
induce UDS and strand breakage in human peripheral blood lymphocytes (19) and mouse epidermal keratinocytes (20). Also, it was shown that in human diploid fibroblasts, excision repair of $( \pm$ )-anti-BPDE-DNA adducts may be preferential and strand-specific (21).

DNA excision repair activity has been reported to show considerable interindividual variation $(19,22)$, which could be due to differences in endogenous repair capacity as well as to influences by environmental and lifestyle factors. Since BPDE-induced mutagenesis has been found to be inversely related to repair of BPDE-dG adducts $(15,17,23)$ investigation of repair modulating factors is pivotal. One of these factors may be the individual niacin status, since niacin is one of the precursors of nicotinamide adenine dinucleotide. If ribosylation is involved in repair of benzo[a]pyrene DNA damage, the availability of intracellular nicotinamide adenine dinucleotide may be a limiting factor in restoring the integrity of DNA after ( \pm )-anti-BPDE-induced damage, and consequently modulate mutagenesis.

In this study, evidence is presented that poly(ADP-ribosylation) takes place during $( \pm)$-anti-BPDE-induced DNA repair in PHA stimulated human peripheral blood lymphocytes. Also $\mathrm{NAD}^{+}$depletion, unscheduled DNA synthesis (UDS) and removal of ( \pm )-anti-BPDE- $\mathrm{N}^{2}-\mathrm{dG}$ adducts were examined, to gain additional evidence for a possible involvement of poly(ADP-ribosylation) in repair of $( \pm)$-anti-BPDE DNA damage.

\section{Materials and methods}

\section{Cell culture}

Human peripheral blood lymphocytes (PBLs) were isolated from 14 buffycoats (prepared from $500 \mathrm{ml}$ blood of healthy blood donors). Buffycoats were diluted 1 : 4 (v/v) with RPMI 1640 medium prior to isolation of lymphocytes on Lymphoprep $^{\mathrm{TM}}$ (Nycomed). After centrifugation at $800 \mathrm{~g}$, the interfaces were collected, washed with RPMI 1640 medium and pooled. In case of obvious red blood cell contamination, erythrocytes were lysed in $155 \mathrm{mM} \mathrm{NH}_{4} \mathrm{Cl}, 10 \mathrm{mM}$ $\mathrm{KHCO}_{3}, 10 \mathrm{mM}$ EDTA, pH 7.4. Mononuclear cells were counted using a haemocytometer and viability was determined using trypan blue exclusion. In general, a yield of about $5 \times 10^{8}$ viable cells per buffycoat was obtained.

Cells were adjusted to a density of $1-2 \times 10^{6}$ cells/ml RPMI 1640 medium supplemented with $15 \%(\mathrm{v} / \mathrm{v})$ foetal calf serum (FCS), L-glutamine, $100 \mathrm{U} / \mathrm{ml}$ penicillin, $100 \mu \mathrm{g} / \mathrm{ml}$ streptomycin (complete medium) and grown for $48 \mathrm{~h}$ in presence of $40 \mu \mathrm{l}( \pm 52 \mu \mathrm{g})$ phytohemagglutinin $(\mathrm{PHA}) / \mathrm{ml}$ medium in culture flasks in a humidified incubator at $37^{\circ} \mathrm{C}$ under $5 \% \mathrm{CO}_{2}$.

For synthesis of [adenine- $\left.{ }^{14} \mathrm{C}\right]$ poly(ADP-ribose) (see below), human diploid fibroblasts were cultured in Ham's F10 medium, supplemented with $20 \%$ FCS, $100 \mathrm{U} / \mathrm{ml}$ penicillin, $100 \mu \mathrm{g} / \mathrm{ml}$ streptomycin under the conditions described above. Medium was refreshed every 2-3 days. Cells were trypsinized with $0.3 \%$ 


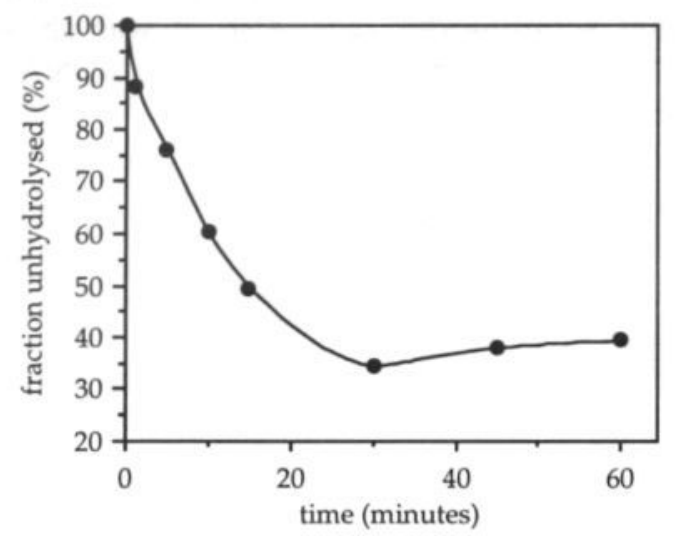

Figure 3.1. Time dependent hydrolysis of $( \pm)-7 \beta, 8 \alpha$-dihydroxy- $9 \alpha, 10 \alpha$-epoxy$7,8,9,10$-tetrahydrobenzo[a]pyrene in RPMI 1640 medium without supplements, at $37^{\circ} \mathrm{C}$.

trypsin prior to use or reseeding at a density of approximately $1.5 \times 10^{6}$ cells $/ 162$ $\mathrm{cm}^{2}$. All cell culture media and supplements were from Gibco, Europe.

Treatment of lymphocytes with carcinogens

After 46-48 hours of culturing, lymphocytes were treated with ( \pm )-anti-BPDE (Midwest Research Institute) or MNNG ( $N$-methyl- $N$ '-nitro- $N$ nitrosoguanidine, Serva), which served as a positive control since treatment of resting human PBLs with MNNG for 10 minutes has been reported to yield maximum poly(ADP-ribose) polymer levels (24). Before treatment, adhering cells were scraped from the culture flask and the resulting suspension was centrifuged. Medium was saved and stored for post-treatment cell culture, and cells were suspended in RPMI 1640 medium without supplements.

Hydrolysis of ( \pm )-anti-BPDE in RPMI 1640 at $37{ }^{\circ} \mathrm{C}$ was determined as described by MacLeod and Lew (25) and found to be rapid with a half-life of approximately 15 minutes (see Figure 3.1). Previously, it was shown that treatment of two mammalian cell lines with $( \pm)$-anti-[ $\left.{ }^{3} \mathrm{H}\right] \mathrm{BPDE}$ for 15 minutes resulted in maximum binding to DNA, while after prolonged treatment no increased binding was observed (26). Therefore, it is likely that most of the ( \pm )anti-BPDE-induced DNA damage in human PBLs occurs within the initial 15 minutes of exposure.

$( \pm)$-anti-BPDE, dissolved in anhydrous DMSO, was diluted in RPMI 1640 to the required final concentrations in subdued light just prior to addition to the cell suspension in order to minimize the effect of hydrolysis on the effective dose. Cells were incubated at a density of $10 \times 10^{6}$ cells $/ \mathrm{ml}$ at $37^{\circ} \mathrm{C}$, during 15 minutes (or longer as indicated below, for determination of $\mathrm{NAD}^{+}$and 
poly(ADP-ribose) polymer levels at different time points after incubation). Control cells were exposed to a maximum concentration of $0.6 \%$ DMSO.

For UDS determination, the treatment protocol was slightly different. 48 hours after PHA stimulation, ( \pm )-anti-BPDE dissolved in DMSO (final concentration: $1 \%$ ) was added to approximately $1 \times 10^{6}$ cells by micropipette to the desired final concentration. Within 15 minutes, [methyl- ${ }^{3} \mathrm{H}$ ] thymidine (Amersham, specific activity $82 \mathrm{Ci} / \mathrm{mmol}$ ) was added to a final concentration of $10 \mu \mathrm{Ci} / \mathrm{ml}$ and cells were cultured for 24 hours at a density of $1-2 \times 10^{6}$ cells $/ \mathrm{ml}$ until harvesting.

\section{Determination of ribosylation in carcinogen treated cells}

Aliquots, containing at least $50 \times 10^{6}$ cells were transferred to $50 \mathrm{ml}$ culture tubes on ice at different time points $(15,35$, and 55 minutes), after exposure to various concentrations of $( \pm)$-anti-BPDE or MNNG, in order to determine PADPRT activity. These time points were selected since other studies indicated that carcinogen induced (ADP-ribose) polymer formation and breakdown is a dynamic process, proceeding in general within a period of $1-2$ hours $(6,24,27)$. The material was precipitated in $20 \%$ TCA and the amount of poly(ADP-ribose) in the acid insoluble fraction was determined according to the procedure described by Jacobson (28). Dihydroxyboryl Bio-Rex 70 chromatography was applied to adsorb polymeric ADP-ribose, after which enzymatic hydrolysis of the phosphodiester linkages with snake venom phosphodiesterase (Worthington) and alkaline phosphatase (Sigma) yielded the adenine derivatives ribosyladenosine and diribosyladenosine. Fluorescent etheno-derivatives from these nucleosides were synthesized under acidic conditions with chloroacetaldehyde. A purification step with Matrex Gel PBA- 60 was omitted since under the conditions described below, a good resolution of the ethenoadenosine and ethenoribosyladenosine peaks was achieved.

Fluorescent nucleosides derived from poly(ADP-ribose) were separated on a Hichrom nucleosil $1205 \mathrm{C} 18$ column $(250 \times 4.6 \mathrm{~mm}$ i.d.). The injection volume was $200 \mu \mathrm{l}$. The column was isocratically eluted at room temperature with $85 \%$ methanol/15\% $7 \mathrm{mM}$ ammonium formate, $\mathrm{pH} 5.8(\mathrm{v} / \mathrm{v})$ delivered by a Kratos Spectroflow 480 solvent delivery system at a flow rate of $0.8 \mathrm{ml} /$ minute. Monitoring of the fluorescent nucleosides was performed by a Kratos Spectroflow 980 programmable fluorescence detector with an excitation wavelength of $220 \mathrm{~nm}$ and an emission wavelength of $370 \mathrm{~nm}$. Reference samples of ethenoadenosine, ethenoribosyladenosine and ethenodiribosyladenosine were kindly provided by Dr. Myron K. Jacobson from the Department of Anatomy and Cell Biology, Texas College of Osteopathic Medicine, University of North Texas, Forth Worth, Texas, U.S.A. Pure ethenoadenosine was obtained from Sigma. The detection limit was $1 \mathrm{pmol}$ absolute. 
To check for overall recovery, DHB-Biorex purified [adenine ${ }^{14} \mathrm{C}$ ]poly(ADPribose) was added to each acid insoluble pellet, prior to determination of poly(ADP-ribose) polymers (28). [adenine- ${ }^{14}$ C]poly(ADP-ribose) was prepared according to Alvarez-Gonzalez (29). Human fibroblasts from 12 to 20 confluent $165 \mathrm{~cm}^{2}$ flasks were permeabilized during 15 minutes at a cell density of $2 \times 10^{6}$ cells in ice-cold $10 \mathrm{mM}$ Tris- $\mathrm{HCl}, \mathrm{pH} 7.8,1 \mathrm{mM}$ EDTA, $0.05 \%$ Triton X-100, $4 \mathrm{mM}$ $\mathrm{MgCl}_{2}, 30 \mathrm{mM} \beta$-mercaptoethanol. Subsequently, cells were centrifuged at $1000 \mathrm{~g}$ for 10 minutes at $4{ }^{\circ} \mathrm{C}$ and resuspended in assay buffer containing $40 \mathrm{mM}$ Tris$\mathrm{HCl} \mathrm{pH} 7.8,1 \mathrm{mM} \beta$-mercaptoethanol, $1 \mathrm{mM}$ phenylmethylsulfonylfluoride, 200 $\mu \mathrm{g} / \mathrm{ml}$ DNase I (Boehringer Mannheim), $0.5 \mathrm{mM} \mathrm{NAD}^{+}$(Sigma) and 5-10 $\mu \mathrm{Ci}$ [Ade-U-14C]NAD ${ }^{+}$(NEN, DuPont). The reaction mixture was incubated at $30^{\circ} \mathrm{C}$, during 30 minutes. The reaction was stopped by the addition of TCA to a final concentration of $20 \%(\mathrm{w} / \mathrm{v})$, and cooling on ice for 15 minutes. Precipitated material was pelleted by centrifugation and purified on a DHB-Biorex column.

\section{$N A D^{+}$determination}

An aliquot of incubation medium, containing at least $5 \times 10^{6}$ cells, was taken 55 minutes after treatment, since previous studies indicate that carcinogen induced $\mathrm{NAD}^{+}$depletion takes place within \pm 1 hour after treatment $(24,30-32)$. Incubation medium was removed after centrifugation of the cell suspension for $10^{\prime}$ at $400 \mathrm{~g}$ and pyridine nucleotides were extracted from the pellet with $2.0 \mathrm{ml}$ ice-cold $0.1 \mathrm{M} \mathrm{NaOH}$ and $1 \mathrm{mM}$ nicotinamide, followed by a $1.0 \mathrm{ml}$ wash of the tube. The extract was neutralized to $\mathrm{pH} 7.3( \pm 0.05)$ and stored at $-20{ }^{\circ} \mathrm{C}$ prior to the determination of $\mathrm{NAD}^{+}$. Intracellular $\mathrm{NAD}^{+}$levels were determined using the enzymatic cycling assay of Bernofsky and Swan (33). The frozen extract was thawed and reduced pyridine nucleotides in the extract were oxidized by addition of $200 \mu \mathrm{l} 2.0 \mathrm{mM}$ phenazine ethosulfate. An aliquot of $200 \mu \mathrm{l}$ of the extract (or standard $\mathrm{NAD}^{+}$in bidest) was added to a preincubated reaction mixture, containing final concentrations of $1.67 \mu \mathrm{mol} / \mathrm{ml}$ phenazine ethosulfate, 0.42 $\mu \mathrm{mol} / \mathrm{ml} \mathrm{MTT}, 60 \mu \mathrm{mol} / \mathrm{ml}$ bicin $\mathrm{pH} 7.8,0.167 \mathrm{mg} / \mathrm{ml}$ alcoholdehydrogenase and $0.5 \mu \mathrm{mol} / \mathrm{ml}$ ethanol and incubated for exactly 30 minutes at $30^{\circ} \mathrm{C}$. Assay chemicals were all from Sigma. Absorption of the reaction mixture was immediately after incubation measured at $570 \mathrm{~nm}$, at room temperature, using a Beckman DU 648 spectrophotometer.

\section{Determination of persistence of ( \pm -anti-BPDE- $N^{2}-d G$ adducts}

After incubation of lymphocytes with ( \pm )-anti-BPDE for 15 minutes, at least $15 \mathrm{x}$ $10^{6}$ cells were transferred to $10 \mathrm{ml}$ tubes, which were centrifuged at room temperature for $10^{\prime}$ at $400 \mathrm{~g}$. This time point is indicated as $\mathrm{t}=0$ hours. Subsequently, the pellet was dissolved in $1 \mathrm{ml} 5 \%$ SDS, incubated with $136 \mu \mathrm{g} / \mathrm{ml}$ RNase $\mathrm{A}$ and $18 \mathrm{U} / \mathrm{ml}$ RNase T1 (both from Boehringer Mannheim) for 30 minutes at $37{ }^{\circ} \mathrm{C}$. Samples were digested overnight with $4.0 \mathrm{ml}$ of $50 \mu \mathrm{g} / \mathrm{ml}$ proteinase $\mathrm{K}$ in $75 \mathrm{mM} \mathrm{NaCl}, 25 \mathrm{mM}$ EDTA. DNA was extracted once with 
phenol : chloroform : isoamylalcohol $(25: 24: 1, \mathrm{v} / \mathrm{v} / \mathrm{v})$, once with chloroform : isoamylalcohol $(24: 1, \mathrm{v} / \mathrm{v})$ and precipitated through addition of $1 / 30$ volume 3 $\mathrm{M}$ sodiumacetate $\mathrm{pH} 5.2$ and an equal volume of ice-cold isopropanol. DNA was washed with cold $70 \%$ ethanol and dissolved in $2 \mathrm{mM}$ Tris- $\mathrm{HCl} \mathrm{pH}$ 7.4. DNA concentration was determined as described by Warburg and Christian (34). Cultures used for determination of $\left( \pm\right.$ )-anti-BPDE- $\mathrm{N}^{2}-\mathrm{dG}$ adduct levels at 4 and 24 hours after exposure were subjected to a second incubation in saved RPMI 1640 complete medium containing growth factors, diluted with fresh complete medium $(75: 25, \mathrm{v} / \mathrm{v})$ at a density of $1-2 \times 10^{6}$ cells $/ \mathrm{ml}$. At the respective time points, DNA was isolated as described above. The level of BPDE-dG adducts was determined according to Reddy and Randerath (35), using the nuclease P1 enhanced ${ }^{32} \mathrm{P}$-postlabeling method. Chromatograms were visualized and quantified using a Molecular Dynamics Phosphor Imager with Image Quant ${ }^{\mathrm{TM}}$ software.

The adduct level of $( \pm)$-anti-BPDE- $\mathrm{N}^{2}$-dG per unit DNA was corrected for cell proliferation by dividing the number of adducts by the amount of DNA minus the amount of newly synthesized DNA, estimated from the labeling index, according to the following formula:

Adduct level $=\frac{\text { Number of adducts }}{\text { (Number of nucleotides }-\mathrm{X} \% * \text { Number of nucleotides) }}$

(where $\mathrm{X} \%=$ labeling index).

\section{Determination of labeling index}

In order to determine the effect of cell proliferation on ( \pm )-anti-BPDE- $\mathrm{N}^{2}-\mathrm{dG}$ adduct levels, $5 \times 10^{6}$ cells were suspended at a density of $1-2 \times 10^{6}$ cells $/ \mathrm{ml}$ in a mixture of saved complete medium/fresh complete medium $(75: 25, \mathrm{v} / \mathrm{v}$ ), immediately after treatment with ( \pm )-anti-BPDE for 15 minutes, and BrdU was added to a final concentration of $26.0 \mu \mathrm{M}$. After 24 hours, cells were hypotonized in $75 \mathrm{mM} \mathrm{KCl}$ and fixed three times in methanol : acetic acid $(3: 1, \mathrm{v} / \mathrm{v})$. Part of the cell suspension was pipetted on slides, dried and stained using an immunohistochemical procedure as described elsewhere (36), applying monoclonal anti-BrdU. Slides were counterstained in 5\% Giemsa for 3 minutes. The labeling index was determined by counting the number of BrdU positive (brown) nuclei per 1000 nuclei. To determine the direct effect of $( \pm)$-anti-BPDE treatment on cell proliferation, per concentration at least $5 \times 10^{6}$ cells were cultured, treated and processed essentially as described above.

\section{Determination of unscheduled DNA synthesis}

After treatment with $( \pm)$-anti-BPDE and incubation with [methyl$\left.{ }^{3} \mathrm{H}\right]$ thymidine, cells were harvested as described for determination of the labeling 
index above. Slides were prepared and processed for autoradiography using Ilford K2 Scientific Emulsion. After 10-14 days, slides were developed and cells were counterstained for 30 seconds in haematoxilin. The degree of UDS was determined by counting the number of grains in at least 50 nuclei per culture, using a normal light microscope with 1000x magnification. The net number of grains/nucleus was obtained by correcting the number of nuclear grains for background grains (by substracting the mean number of grains in two areas equal to the nucleus situated right and left of it, according to Harbach et al. (37)). Grains in heavily labeled cells, representing cells in S-phase (in which separate grains could not be counted), were excluded from the analysis.

\section{Statistical analysis}

Associations between parameters of DNA damage and repair were statistically analyzed by means of simple regression.

\section{Results}

To determine whether poly(ADP-ribose) polymer synthesis is involved in DNA damage and repair of $( \pm)$-anti-BPDE treated PHA-stimulated human peripheral blood lymphocytes, in a series of experiments the amount of ethenoribosyladenosine was measured at different time points after treatment with concentrations ( \pm )-anti-BPDE ranging from $2.5-40 \mu \mathrm{M}$. In Figure 3.2, for two separate experiments, a dose dependent induction of poly(ADP-ribosylation) at two time points after treatment of PHA stimulated human peripheral blood lymphocytes with ( \pm )-anti-BPDE is shown. Treatment with $40 \mu \mathrm{M}( \pm)$-antiBPDE during 15 and 35 minutes results in an approximately 2-10 fold increase in ethenoribosyladenosine ( $\varepsilon$ Rado) levels. In Figure 3.3 (experiment 3 ), the amount of $\varepsilon$ Rado, measured after 15,35 and 55 minutes of ( \pm )-anti-BPDE exposure, is shown for lymphocytes, obtained from three buffycoats. For PBLs from two donors, an increase in formation of poly(ADP-ribose) polymer was found proceeding until 35 minutes of exposure to $40 \mu \mathrm{M}( \pm)$-anti-BPDE, after which polymer synthesis decreased or polymer breakdown by glycohydrolases increased. In PBLs of one donor, the formation of polymers still increased after 35 minutes of exposure, although to a lesser extent. In none of the experiments, ethenodiribosyladenosine was detected.

As a positive control, lymphocytes were incubated with various concentrations MNNG, a known inductor of poly(ADP-ribosylation) (27,38). MNNG treatment was indeed found to induce poly(ADP-ribose) polymer formation in PHA stimulated human peripheral blood lymphocytes from different buffycoats, as is shown in Table 3.1 (experiment 4). From Figures 3.2 and 3.3 and Table 3.1 it is evident that interindividual differences with regard to the extent of endogenous as well as ( \pm )-anti-BPDE and MNNG induced ribosylation exist. 
experiment 1

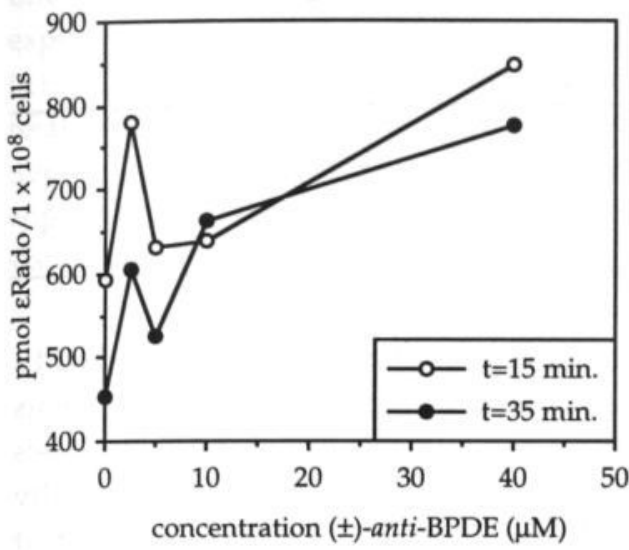

experiment 2

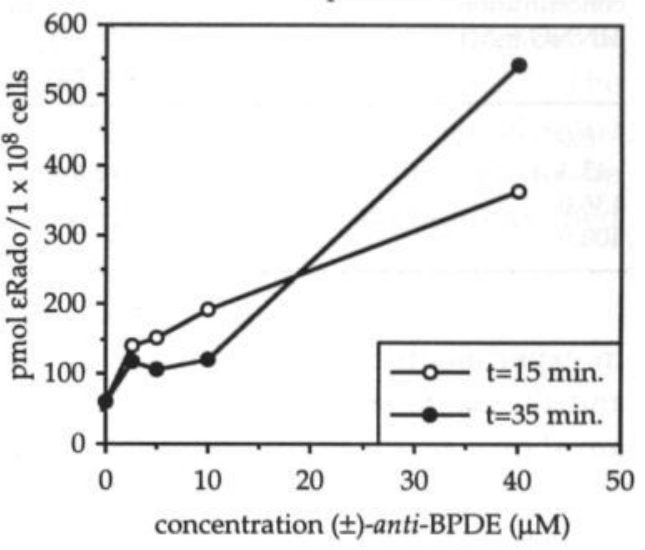

Figure 3.2. Induction of poly(ADP-ribosylation), determined as pmol $\varepsilon$ Rado $/ 10^{8}$ cells, in PHA stimulated human peripheral blood lymphocytes obtained from two donors, measured after treatment with ( \pm )-anti-BPDE for 15 and 35 minutes.

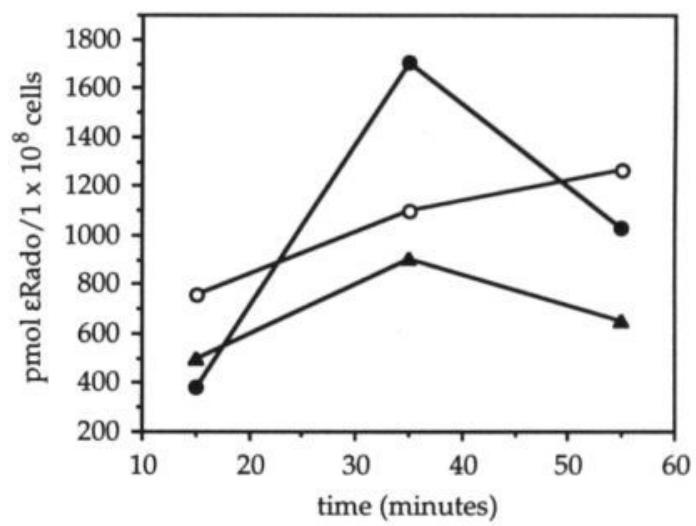

Figure 3.3. Poly(ADP-ribosylation), determined as pmol $\varepsilon$ Rado $/ 10^{8}$ cells in PHA stimulated human peripheral blood lymphocytes, obtained from three different donors, after treatment with $40 \mu \mathrm{M}( \pm)$-anti-BPDE for 15, 35 and 55 minutes. 
Table 3.1. Determination of poly(ADP-ribose) polymers, determined as pmol $\varepsilon$ Rado $/ 10^{8}$ cells, in PHA stimulated human peripheral blood lymphocytes, obtained from two different donors, after treatment with $N$-methyl- $N^{\prime}$-nitro- $N$-nitrosoguanidine for 10 minutes.

\begin{tabular}{lcr}
\hline \multirow{2}{*}{$\begin{array}{l}\text { concentration } \\
\text { MNNG }(\mu \mathrm{M})\end{array}$} & \multicolumn{2}{c}{ Rado $\left(\mathrm{pmol} / 1 \times 10^{8}\right.$ cells $)$} \\
\cline { 2 - 3 } & donor 1 & donor 2 \\
\hline 0.0 & 67.5 & 261.9 \\
45.3 & 442.4 & 1857.7 \\
136.0 & 2812.0 & 10958.3 \\
408.0 & 4156.3 & 12806.9 \\
\hline
\end{tabular}

In experiments 5 and 6, pyridine nucleotides were extracted from exposed PBLs and the amount of $\mathrm{NAD}^{+}$was determined. The results from these experiments are shown in Table 3.2. A dose dependent decrease in intracellular $\mathrm{NAD}^{+}$levels after $( \pm$ )-anti-BPDE treatment was observed (although not statistically significant), indicating ( \pm )-anti-BPDE-induced $\mathrm{NAD}^{+}$turnover. Already at concentrations as low as $0.2 \mu \mathrm{M},( \pm)$-anti-BPDE caused a decrease in intracellular $\mathrm{NAD}^{+}$levels. In addition, in the same experiments, the effect of ( \pm )-anti-BPDE treatment on the incorporation of BrdU, 48-72 hours after PHA stimulation is shown in Table 3.2. Exposure to $0.2 \mu \mathrm{M}( \pm)$-anti-BPDE was found to reduce BrdU incorporation, indicating inhibition of replicative DNA synthesis. The effects of $( \pm)$-anti-BPDE treatment on intracellular $\mathrm{NAD}^{+}$levels of PBLs showed a statistically significant dose dependent correlation with labeling indices $(r=0.91$, $\mathrm{p}<0.05)$, indicating that $( \pm)$-anti-BPDE-induced dose-dependent $\mathrm{NAD}^{+}$depletion is concomitant to inhibition of cell proliferation.

Table 3.2. The effect of ( \pm -anti-BPDE treatment of PHA stimulated human peripheral blood lymphocytes on intracellular $\mathrm{NAD}^{+}$levels and labeling index.

\begin{tabular}{lll}
\hline $\begin{array}{l}\text { concentration } \\
( \pm) \text {-anti-BPDE }(\mu \mathrm{M})\end{array}$ & $\begin{array}{l}{ }^{\mathrm{a}} \mathrm{NAD}^{+} \\
\left(\mathrm{pmol} / 1 \times 10^{6} \text { cells }\right)\end{array}$ & $\begin{array}{l}\text { labeling index } \\
(\% \text { BrdU positive cells })\end{array}$ \\
\hline 0.0 & $164.8 \pm 31.3$ & $10.5 \pm 1.1$ \\
0.2 & $126.7 \pm 45.6$ & $9.4 \pm 2.8$ \\
0.5 & $108.0 \pm 50.9$ & $6.9 \pm 3.5$ \\
1.0 & $121.9 \pm 62.7$ & $6.7 \pm 5.8$ \\
2.5 & $97.3 \pm 50.9$ & $5.5 \pm 0.9$ \\
\hline
\end{tabular}

Mean results $( \pm S D$ ) are presented for lymphocytes, obtained from two donors.

${ }^{a}$ Significant correlation between $( \pm)$-anti-BPDE-induced $\mathrm{NAD}^{+}$depletion and inhibition of $\mathrm{BrdU}$ incorporation $(r=0.91, \mathrm{p}<0.05)$.

Unscheduled DNA synthesis (UDS) and ( \pm )-anti-BPDE- ${ }^{2}$-deoxyguanosine adduct removal were determined after treatment of PHA stimulated human PBLs with ( \pm )-anti-BPDE, to study processes related to excision repair. In Figure 3.4, UDS in lymphocytes obtained from two donors is shown. A linear $(r=0.999$, 
$\mathrm{p}<0.02)$ UDS response was observed, whereas no indication for interindividual variation was found. While at $1.0 \mu \mathrm{M}$ a clear UDS response was observed, other experiments indicated that after treatment with $0.5 \mu \mathrm{M}( \pm)$-anti-BPDE, UDS was undetectable or near the detection limit (results not shown). In contrast, after exposure to $0.5 \mu \mathrm{M}( \pm)$-anti-BPDE, a clear time dependent decrease in number of $( \pm)$-anti-BPDE- $\mathrm{N}^{2}-\mathrm{dG}$ adducts was measured, as is shown in Figure 3.5. The relative number of adducts per nucleotide is shown, since in most samples the degree of modification after $0.5 \mu \mathrm{M}$ treatment, which was found to be approximately 1 adduct per $10^{4}$ to $10^{5}$ nucleotides, exceeded the highest modified standard available, which had 1 adduct per $10^{7}$ nucleotides.

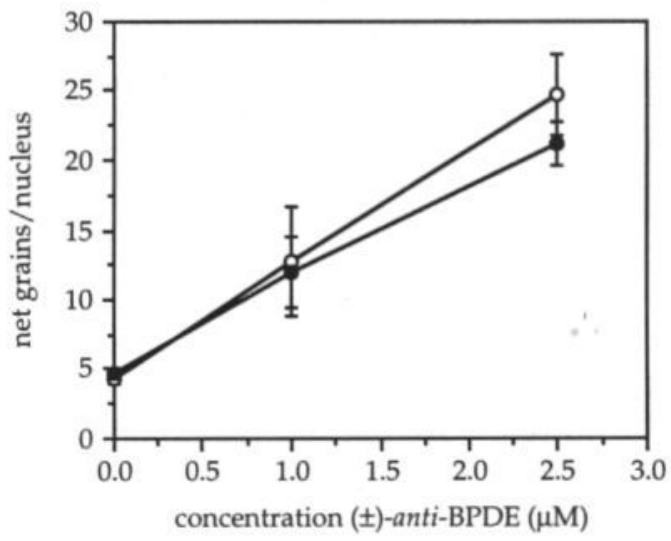

Figure 3.4. Induction of unscheduled DNA synthesis in PHA stimulated human peripheral blood lymphocytes 24 hours after treatment with ( \pm )-anti-BPDE Results are shown for PBLs, obtained from two donors. Each point represents the mean net number of grains per nucleus obtained from two cultures of one donor.

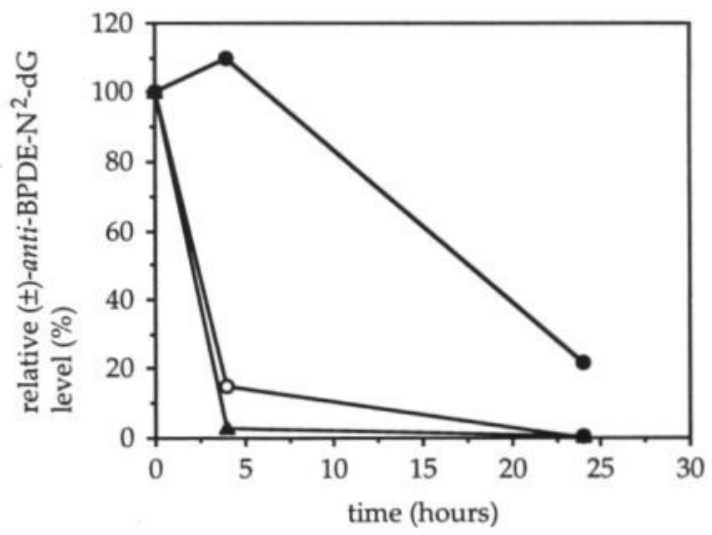

Figure 3.5. Measurement of ( \pm -anti-BPDE-deoxyguanosine adduct persistence in PHA stimulated human peripheral blood lymphocytes, obtained from three buffycoats, after treatment with $0.5 \mu \mathrm{M}( \pm)$-anti-BPDE for 15 minutes. Results are corrected for cell proliferation. 


\section{Discussion}

In this study, evidence is presented that poly(ADP-ribosylation) is activated during ( \pm )-anti-BPDE-induced DNA damage in PHA stimulated human peripheral blood lymphocytes. Since two DNA repair related processes, e.g. UDS and ( \pm -anti-BPDE-deoxyguanosine adduct removal after ( \pm )-anti-BPDE treatment, were also observed, it might be that poly(ADP-ribosylation) is involved in repair of ( \pm )-anti-BPDE-DNA lesions in these cells.

A clear dose-dependent induction of poly(ADP-ribosylation) was observed after treatment of PHA stimulated human peripheral blood lymphocytes with $( \pm)$-anti-BPDE, at different exposure times. At a concentration of $0.5 \mu \mathrm{M}( \pm)-$ anti-BPDE, no clear induction of ribosylation was found, which may be due to the relatively high detection limit of the assay but at concentrations as low as 0.2 $\mu \mathrm{M}$, a decrease in cellular $\mathrm{NAD}^{+}$content was observed. These results suggest that poly(ADP-ribosylation) is a process already active at low carcinogen concentrations. It is not known however, whether ( \pm )-anti-BPDE is able to interfere directly, within 55 minutes, with the $\mathrm{NAD}^{+}$glycohydrolase, which converts $\mathrm{NAD}^{+}$to mono(ADP-ribose) and nicotinamide, or with $\mathrm{NAD}^{+}$ synthesis from extracellular nicotinamide or intracellular nicotinic acid. On the other hand, other studies have shown that in mammalian cells, which were $\mathrm{NAD}^{+}$depleted by various carcinogens, complete resynthesis of $\mathrm{NAD}^{+}$ (dependent on type and extent of DNA damage) within one hour hardly occurs $(24,30,39)$. Therefore, within this time period, the attribution of de novo synthesized $\mathrm{NAD}^{+}$to intracellular $\mathrm{NAD}^{+}$levels in ( \pm )-anti-BPDE treated human PBLs is likely to be limited.

A clear dose-dependent depletion of $\mathrm{NAD}^{+}$has previously been reported after treatment of unstimulated human PBLs with high concentrations ( \pm )-anti-BPDE (ranging from $9.9-66 \mu \mathrm{M}$ ). Other DNA damaging metabolites of polycyclic aromatic hydrocarbons were also reported to be capable of inducing $\mathrm{NAD}^{+}$ depletion, at concentrations ranging from $39.6 \mu \mathrm{M}-75.1 \mu \mathrm{M}$ (30). In the present study, $\mathrm{NAD}^{+}$depletion was already observed at concentrations as low as $0.2 \mu \mathrm{M}$ $( \pm)$-anti-BPDE, which may be explained by the use of proliferating PBLs. PHA stimulated lymphocytes have been reported to contain higher concentrations of polymerase molecules as compared to unstimulated lymphocytes and to show higher $\left[{ }^{3} \mathrm{H}\right] \mathrm{NAD}^{+}$incorporation after permeabilization and DNase I treatment (40). Therefore, ( \pm )-anti-BPDE-induced poly(ADP-ribosylation), and consequently $\mathrm{NAD}^{+}$depletion, may be expected to occur sooner or at lower exposure levels in PHA stimulated PBLs. In this respect, X-ray induced poly(ADP-ribose) polymerase activity in permeabilized cells was reported to be at least twice as high in proliferating versus quiescent murine tumor cell lines (41).

At increasing concentrations of ( \pm -anti-BPDE, a correlation was observed between the decrease in cellular $\mathrm{NAD}^{+}$levels and the inhibition of $\mathrm{BrdU}$ incorporation during 24 hours after treatment. Inhibition of cloning efficiency to 
about $20 \%$ has been reported for human peripheral blood lymphocytes $(47,48)$ after treatment with low concentrations of $( \pm)$-anti-BPDE ranging from $0.12 \mu \mathrm{M}$ $0.3 \mu \mathrm{M}$. This proliferation inhibiting effect has been interpreted as cytotoxicity and related to the occurrence of DNA adducts $(49,50)$. ( \pm )-anti-BPDE-DNA adducts have been shown to interfere with normal cellular processes like replicative DNA synthesis $(62,63)$ and mRNA transcription (64). Alternatively, since $\mathrm{NAD}^{+}$depletion has been related with ATP depletion and cell lysis (7), it might be that the observed inhibition of DNA synthesis in this study is partially indirectly related to these events.

At the experimental conditions in the present study, relatively high concentrations of $( \pm)$-anti-BPDE were necessary to induce inhibition of DNA synthesis. In contrast, lower concentrations ( \pm )-anti-BPDE already reduced the colony forming ability of PHA stimulated human PBLs in other studies $(47,48)$. This discrepancy may be explained by differences between the methods used: inhibition of cell proliferation determined as inhibition of DNA synthesis during 24 hours after exposure, is not necessarily comparable to reduction of Tcell cloning which is determined over a period of 7-12 days. Also, experimental factors such as cell density and cell-cycle distribution at the moment of $( \pm)$-antiBPDE treatment, as well as incubation time (26) differ between the present and the cited studies $(47,48)$ which may explain differences in $( \pm)$-anti-BPDE susceptibility.

After treatment with $0.5 \mu \mathrm{M}( \pm)$-anti-BPDE, the UDS response was found to be near the detection limit, which is in agreement with results published previously for unstimulated human PBLs (19). In contrast, formation and time dependent decrease of $( \pm)$-anti-BPDE- $\mathrm{N}^{2}$-dG adduct levels was detected at this concentration. Although the absolute adduct levels in the present study were not determined, it is estimated that after $( \pm)$-anti-BPDE-induced DNA damage, a modification level of at least 1 adduct per $10^{4}$ to $10^{5}$ nucleotides is required to induce measurable UDS. The higher sensitivity of carcinogen-adduct determination as compared to UDS in studying DNA damage and repair is confirmed by other studies, using cultured mouse epidermal keratinocytes, treated with ( \pm )-anti-BPDE and other PAH carcinogens (20) and hepatocytes from $\mathrm{N}$-acetylaminofluorene treated rodents in vivo $(51,52)$.

In the present study, only at concentrations higher than $10 \mu \mathrm{M}( \pm)$-anti-BPDE, poly(ADP-ribosylation) could be measured after 15 and 35 minutes of exposure. Other studies, applying either $\left[{ }^{3} \mathrm{H}\right] \mathrm{NAD}$ incorporation after permeabilization or DHB-Biorex chromatography or in situ immunofluorescent detection of PADPRT activity, also indicate that treatment with relatively high concentrations, ranging from $50 \mu \mathrm{M}$ up to $5 \mathrm{mM}$ of carcinogens such as cumenehydroperoxide, cisplatin, $\mathrm{H}_{2} \mathrm{O}_{2}$, and $N$-methyl- $N$-nitrosourea, are required to detect PADPRT activity $(6,7,38,53,54,55)$. Therefore, it is concluded that as a parameter of DNA damage and repair in $( \pm)$-anti-BPDE treated 
stimulated human PBLs, measurement of poly(ADP-ribose) polymer formation is less sensitive than the other repair parameters, UDS and DNA adduct persistence.

The mechanism of carcinogen-induced ribosylation is not clear at present. It has been demonstrated that the presence of DNA single or double DNA strand breaks is a prerequisite for induction of ribosylation $(6,7,38,42)$. After $( \pm)$-antiBPDE exposure in vitro, strand break formation in mammalian cells has been shown to occur $(19,43)$. The clear UDS response, observed in the present study, is also in agreement with the transient existence of single-stranded DNA. It appears that $( \pm$-anti-BPDE-induced single-strand breaks activate PADPRT, which then becomes automodified. Activation of PADPRT might occur initially on easy accessible lesions, perhaps located in transcriptionally active regions, as may be expected if $( \pm)$-anti-BPDE-induced repair is preferential for these regions (21). Subsequently, the automodified PADPRT would dissociate from the DNA, having higher affinity for histones which results in DNA-nucleosome dissociation, allowing increased access of repair enzymes to other ( \pm )-anti-BPDEinduced lesions (8). After repair at these sites, poly(ADP-glycohydrolase) in turn would degrade the polymer, allowing reassociation of histone-DNA complexes. In the present study, a decrease in polymer levels was found in lymphocytes, obtained from two donors 35 minutes after exposure, indicating poly(ADPglycohydrolase) activity.

It remains to be determined which particular excision repair mechanism involves poly(ADP-ribosylation). Recent studies suggest that poly(ADPribosylation) is specifically related to repair of lesions, that are removed via base excision repair, such as induced by UV and MNNG $(59,60)$. In contrast, cisplatin has been shown to induce slow poly(ADP-ribosylation) in mammalian cells (38). In addition, $\mathrm{N}$-acetoxy- $\mathrm{N}$-acetylaminofluorene has been found to cause $\mathrm{NAD}^{+}$ depletion in human PBLs (30). It is not known whether ( \pm -anti-BPDE-induced poly(ADP-ribosylation) is due to nucleotide excision repair of $\left( \pm\right.$ )-anti-BPDE- $\mathrm{N}^{2}$ dG adducts. Other lesions, such as phosphotriesters (46) and N7-guanine adducts $(44,45,61)$ that have been reported to induce apurinic sites in vitro may also be involved. In proliferating cells (HeLa) treated in vitro, however, ( \pm )-anti-BPDEinduced lesions were not found to include apurinic sites (43).

Since interindividual differences were observed in both poly(ADP-ribose) polymer formation, breakdown and $\left( \pm\right.$ )-anti-BPDE- $\mathrm{N}^{2}-\mathrm{dG}$ adduct removal, it may be relevant to investigate whether these differences can be explained by intra-individual relationships between these processes. Interindividual differences in poly(ADP-ribose) polymerase activity have been reported after exposure of human mononuclear leukocytes to different oxygen radical generating systems (56). In addition, it has been found that lower poly(ADPribose) polymerase activities are associated with increased cancer risk $(53,57)$. This study indicates that the $\mathrm{NAD}^{+}$-dependent post-translational modification 
poly(ADP-ribosylation) takes place during repair of ( \pm )-anti-BPDE-induced DNA damage in PHA stimulated human peripheral blood lymphocytes. Furthermore, nicotinic acid supplementation of humans in vivo was reported to increase $\mathrm{NAD}^{+}$levels in isolated PBLs (58), which was related to a reduction of oxygen radical-induced DNA strand breaks in vitro in these cells (58). Therefore, further investigation of the possible relation between interindividual differences in repair processes and niacin status as an exogenous, dietary related factor appears to be warranted.

\section{Acknowledgements}

The authors wish to thank Dr. Myron K. Jacobson and Dr. Nasreen Aboul-Ela from the Texas College of Osteopathic Medicine, Forth Worth, Texas, USA for providing standards and helpful discussions concerning the measurement of polymeric ADP-ribose. This study is supported by grant no. 28-2124 from the 'Praeventiefonds', The Hague, The Netherlands.

\section{References}

1 de Murcia, G., Ménissier-de Murcia, J., Schreiber, V. (1991) Poly(ADPribose) polymerase: molecular biological aspects. Bioessays, 13, 455-462.

2. Boulikas, T. (1991) Relation between Carcinogenesis, chromatin structure and poly(adp)ribosylation (review). Anticancer Res., 11, 489-528.

3. Juarez-Salinas, H., Levi, V., Jacobson, E.L., Jacobson, M.K. (1982) Poly(ADPribose) has a branched structure in vivo. J. Biol. Chem., 257, 607-609.

4. Alvarez-Gonzalez, R., Jacobson, M.K. (1987) Characterization of polymers of adenosine diphosphate ribose generated in vitro and in vivo. Biochemistry, 26, 3218-3224.

5. Satoh, M.S., Lindahl, T., (1992) Role of poly(ADP-ribose) formation in DNA repair. Nature, 356, 356-358.

6. Lautier, D., Poirier, D., Boudreau, A., Alaoui-Jamali, M.A., Castonguay, A., Poirier, G. (1990) Stimulation of poly(ADP-ribose) synthesis by free radicals in C3H10T1/2 cells:relationship with NAD metabolism and DNA breakage. Biochem. Cell. Biol., 68, 602-608.

7. Schraufstatter, I.U., Hinshaw, D.B., Hyslop, P.A., Spragg, R.G., Cochrane, C.G. (1986) Oxidant injury of cells. DNA strand-breaks activate polyadenosine diphosphate-ribose polymerase and lead to depletion of nicotinamide adenine dinucleotide. J. Clin. Invest., 77, 1312-1320.

8. Althaus, F.R. (1992) Poly ADP-ribosylation: a histone shuttle mechanism in DNA excision repair. J. Cell. Sci., 102, 663-670.

9. Realini, C.A., Althaus, F.R. (1992) Histone shutling by poly(ADP-ribosylation). J. Biol. Chem., 267, 18858-18865.

10. Creissen, D., Shall, S. (1982) Regulation of DNA ligase activity by poly(ADP)ribose. Nature, 296, 271-272.

11. Moran, M.F., Ebisuzaki, K. (1985) Inhibition of poly(ADP-ribose)polymerase causes increased DNA strand breaks without decreasing strand rejoining in alkylated HeLa cells. FEBS lett., 190, 279-282.

12. Yoshihara, K., Itaya, A., Tanaka, Y., Ohashi, Y., Ito, K., Teraoka, H., Tsukada, K., Matsukage, A., Kamiya, T. (1985) Inhibition of DNA polymerase $\alpha$, DNA 
polymerase $\beta$, terminal nucleotidyltransferase and DNA ligase II by poly(ADP. ribosyl)ation reaction in vitro. Biochem. Biophys. Res. Commun., 128, 61-67.

13. Junod, A.F., Jornot, L., Petersen, H. (1989) Differential effects of hyperoxia and hydrogen peroxide on DNA damage, polyadenosine diphosphate-ribose polymerase activity, and nicotinamide adenine dinucleotide and adenosine triphosphate contents in cultured endothelial cells and fibroblasts. J. Cell. Physiol., 140, 177-185.

14. Rogan, E.G., Ramakrishna, N.V.S., Higginbotham, S., Cavalieri, E.L., Jeong, H., Jankowiak, R., Small, G.J. (1990) Identification and quantitation of 7-(Benzo[a]pyren6-yl)guanine in the urine and feces of rats treated with benzo[a]pyrene. Chem .Res. Toxicol., 3, 441-444.

15. Yang, Li. L., Maher, V.M., McCormick, J.J. (1982) Relationship between excision repair and the cytotoxic and mutagenic effect of the 'anti' 7,8-diol-9,10-epoxide of benzo[a]pyrene in human cells. Mutat. Res., 94, 435-447.

16. Carothers, A., Grunberger, D. (1990) DNA base changes in benzo[a]pyrene diolepoxide-induced dihydrofolate reductase mutants of chinese hamster ovary cells. Carcinogenesis, 11, 189-192.

17. Chen, R-H., Maher, V.M., McCormick, J.J. (1990) Effect of excision, repair by diploid human fibroblasts on the kind and locations of mutations induced by $( \pm)$ $7 \beta, 8 \alpha$-dihydroxy- $9 \alpha, 10 \alpha$-epoxy-7,8,9,10-tetrahydrobenzo[a]pyrene in the coding region of the HPRT gene. Proc. Natl. Acad. Sci. U.S.A., 87, 8680-8684.

18. Yang, J-L., Chen, R.H., Maher, V.M., McCormick, J.J. (1991) Kinds and location of mutations induced by $( \pm)-7 \beta, 8 \alpha$-dihydroxy- $9 \alpha, 10 \alpha$-epoxy- $7,8,9,10$

tetrahydrobenzo[a]-pyrene in the coding region of the hypoxanthine (guanine)phosphoribosyltransferase gene in diploid human fibroblasts. Carcinogenesis, 12, 71-75.

19. Celotti, L., Ferraro, P., Biasin, M.R. (1992) Detection by fluorescence analysis of DNA unwinding and unscheduled DNA synthesis, of DNA damage and repair induced in vitro by direct-acting mutagens on human lymphocytes. Mutat. Res., 281, 17-23.

20. Gill, R.D., Butterworth, B.E., Nettikumara, A.N. DiGiovanni, J. (1991) Relationship between DNA adduct formation and unscheduled DNA synthesis (UDS) in cultured mouse epidermal keratinocytes. Environ. Mol. Mutagen., 18, 200-206.

21. Chen, R.-H., Maher, V.M., Brouwer, J., van de Putte, P., McCormick, J. J. (1992) Preferential repair and strand-specific repair of benzo[a]pyrene diol epoxide adducts in the HPRT gene of diploid human fibroblasts. Proc. Nat. Acad. Sci. U.S.A., 89, 5413-5417.

22. Oesch, F., Aulmann, W., Platt, K.L., Doerjer, G. (1987) Individual differences in DNA repair capacities in man. Arch. Toxicol. Suppl., 10, 172-179.

23. Yang, L.L., Maher, V.M., McCormick, J.J. (1980) Error-free excision of the cytotoxic, mutagenic $\mathrm{N}^{2}$-deoxyguanosine DNA adduct formed in human fibroblasts by ( \pm - $7 \beta, 8 \alpha$-dihydroxy- $9 \alpha, 10 \alpha$-epoxy-7,8,9,10-tetrahydrobenzo[a]pyrene. Proc. Natl. Acad. Sci. U.S.A., 77, 5933-5937.

24. Sims, J.L., Sikorski, G.W., Catino, D.M., Berger, S.J. Berger, N.A. (1982) Poly(adenosinediphosphoribose) polymerase inhibitors stimulate unscheduled deoxyribonucleic acid synthesis in normal human lymphocytes. Biochemistry, 21, 1813-1821.

25. MacLeod, M.C., Lew, L. (1988) A Rapid, spectrofotometric assay for the integrity of diol epoxides. Carcinogenesis, 9, 2133-2135.

26. Krolewski, B., Little, J.B., Reynolds, R.J. (1988) Effect of duration of exposure to benzo[a]pyrene diol-epoxide on neoplastic transformation, mutagenesis, cytotoxicity, and total covalent binding to DNA of rodent cells, Teratog. Carcinog. Mutagen., 8, 127-136. 
27. Juarez-Salinas, H., Sims, J., Jacobson, M.K. (1979) Poly(ADP-ribose)levels in carcinogen-treated cells. Nature, 282, 740-741.

28. Jacobson, M.K., Payne, D.M., Alvarez-Gonzalez, R., Juarez-Salinas, H., Sims, J.L., Jacobson, E.L. (1984) Determination of in vivo levels of polymeric and monomeric ADP-Ribose by fluorescence methods. Methods Enzymol., 106, 483-494.

29. Alvarez-Gonzalez, R., Juarez-Salinas, H., Jacobson, E.L., Jacobson, M.K. (1983) Evaluation of immobilized boronates for studies of adenine and pyridine nucleotide metabolism. Anal. Biochem., 135, 69-77.

30. Rankin, P.W., Jacobson, M.K., Mitchell, V.R., Busbee, D.L. (1980) Reduction of nicotinamide adenine dinucleotide levels by ultimate carcinogens in human lymphocytes. Cancer Res., 40, 1803-1807.

31. Jacobson, E.L., Antol, K.M., Juarez-Salinas, H., Jacobson, M.K. (1983) Poly(ADPribose) metabolism in ultraviolet irradiated human fibroblasts. J. Biol. Chem., 258, 103-107.

32. Rankin, P.W., Jacobson, E.L., Benjamin, R.C., Moss, J., Jacobson, M.K. (1989) Quantitative studies of inhibitors of ADP-ribosylation in vitro and in vivo, J. Biol. Chem., 264, 4312-4317.

33. Bernofsky, C., Swan, M. (1973) An improved cycling assay for nicotinamide adenine dinucleotide. Anal. Biochem., 53, 452-458.

34. Warburg, O., Christian, W. (1942) Isolierung und kristallisation des Gärungsferments enolase. Biochem. Z., 310, 348-421.

35. Reddy, M.V., Randerath, K. (1986) Nuclease P1-mediated enhancement of sensitivety of ${ }^{32} \mathrm{P}$-postlabeling test for structural diverse DNA adducts. Carcinogenesis, 7, 1543-1551.

36. Stierum, R.H., Hageman, G.J., Welle, I.J., Albering, H.J., Schreurs, J.G.M., Kleinjans, J.C.S. (1993) Evaluation of exposure reducing measures on parameters of genetic risk in a population occupationally exposed to coal fly ash. Mutat. Res., 319, 245-255.

37. Harbach, P.R., Rostami, H.J., Aaron, C.S., Wiser, S.K., Grzegorczyk, C.R. (1991) Evaluation of four methods for scoring cytoplasmic grains in the in vitro unscheduled DNA synthesis (UDS) assay, Mutat. Res., 252, 139-148.

38. Burkle, A., Chen, G., Kupper, J.H., Grube, K., Zeller, W.J. (1993) Increased poly(ADP-ribosyl)ation in intact cells by cisplatin treatment. Carcinogenesis, 14, 559561.

39. Sims, J.L., Berger, S.J., Berger, N.A. (1983) Poly(ADP-ribose) polymerase inhibitors preserve nicotinamide adenine dinucleotide and adenosine $5^{\prime}$-triphosphate pools in DNA-damaged cells: mechanism of stimulation of unscheduled DNA synthesis, Biochemistry, 22, 5188-5194.

40. Yamanaka, H., Pennin, C.A., Willis, E.H., Wasson, D.B., Carson, D.A. (1988) Characterization of human poly(ADP-ribose)polymerase with autoantibodies. $J$. Biol. Chem., 263, 3879-3883.

41. Sweigert, S.E., Marston, J.M., Dethlefsen, L.A. (1990) Poly(ADP-ribose) metabolism in proliferating versus quiescent cells and its relationship to their radiation responses. Int. J. Radiat. Biol., 58, 111-123.

42. Jacobson, E.L., Jacobson, M.K. (1993) A Biomarker for the assessment of niacin nutriture as a potential preventive factor in carcinogenesis. J. Intern. Med., 233, 59-62.

43. Moran, M.F., Ebisuzaki, K. (1991) In vivo benzo[a]pyrene diol epoxide-induced alkali-labile sites are not apurinic sites. Mutat. Res., 262, 79-84.

44. Osborne, M.R., Jacobs, S., Marvey, R.G., Brookes, P. (1981) Minor products from the reaction of $(+)$ and (-) benzo[a]pyrene-anti-diolepoxide with DNA. Carcinogenesis, 2, 553-558.

45. Osborne, M., Merrifield, K. (1985) Depurination of benzo[a]pyrene-diolepoxide treated DNA. Chem. Biol. Interact., 53, 183-195. 
46. Gamper, H.B., Tung, A.S.-C., Straub, K., Bartolomew, J.C. Calvin, M., (1977) DNA strand scission by Benzo[a]pyrene diol epoxides, Science, 197, 671-674.

47. Norimura, T., Maher, V.M., McCormick, J.J. (1990) Cytotoxic and mutagenic effect of UV, ethylnitrosourea and ( \pm )- $7 \beta, 8 \alpha$-dihydroxy- $9 \alpha, 10 \alpha$-epoxy-7,8,9,10. tetrahydrobenzo[a]pyrene in diploid human $\mathrm{T}$ lymphocytes in culture: comparison with fibroblasts. Mutagenesis, 5, 447-451.

48. Andersson, B., Lambert, B. (1990) Mutations induced by benzo[a]pyrene diolepoxide at the hprt locus in human T-lyphocytes in vitro. Mutat. Res., 245, 75 . 82.

49. McCormick, J.J., Maher, V.M. (1985) Cytotoxic and mutagenic effects of specific carcinogen-DNA adducts in diploid human fibroblasts. Environ. Health Perspect., 2, 145-155.

50. Maher, V.M., McCormick, J.J. (1983) Relationship between excision repair and the cytotoxic and mutagenic action of chemicals and UV radiation. Basic Life Sci., 23, 271-290.

51. Gallagher, J.E., Shank, T. Lewtas, J., Lefevre, P.A., Ashby, J. (1991) Relative sensitivity of ${ }^{32} \mathrm{P}$-postlabeling of DNA and the autoradiographic UDS assay in the liver of rats exposed to 2-acetylaminofluorene (2AAF). Mutat. Res., 252, 247-257.

52. Ashby, J., Lefevre, P.A., Șhank, T. Lewtas, J., Gallagher, J.E. (1991) Relative sensitivity of ${ }^{32} \mathrm{P}$-postlabeling of DNA and the autoradiographic UDS assay in the liver of mice exposed to 2-acetylaminofluorene (2AAF). Mutat. Res., 252, 259-268.

53. Markowitz, M.M., Johnson, D.B., Pero, R.W., Winawer, S.J., Miller, D.G. (1988) Effects of cumene hydroperoxide on adenine diphosphate ribosyltransfrease in mononuclear leukocytes of patients with adenomatous polyps in the colon. Carcinogenesis, 9, 349-355.

54. Skidmore, C.J., Davies, M.I., Goodwin, P.M., Halldorsson, H., Lewis, P.J., Shall, S., Zia'ee, A.-A. (1979) The involvement of poly(ADP-ribose) polymerase in the degradation of NAD caused by $\gamma$-radiation and $N$-methyl- $N$-nitrosourea, Eur. J. Biochem., 101, 135-142.

55. Pero, R.W., Jonsson, G.G., Persson, L. (1983) Unscheduled DNA synthesis induced by $\mathrm{N}$-acetoxy-2-acetylaminofluorene is not sensitive to regulation by ADP-ribosyl transferase, Chem. Biol. Interact., 47, 265-275.

56. Pero, R.W., Roush, G.C., Markowitz, M.M., Miller, D.G. (1990) Oxidative stress, DNA repair, and cancer susceptibility. Cancer Detect. Prev., 14, 555-561.

57. Pero, R.W., Johnson, D.B., Miller, D.G., Zang, E., Markowitz, M., Doyle, G.A., LundPero, M., Salford, L., Sordillo, P., Raskin, N., Beattie, E.J. (1989) Adenosine diphosphate ribosyl transferase responses to a standardized dose of hydrogen peroxide in the mononuclear leukocytes of patients with a diagnosis of cancer. Carcinogenesis, 10, 1657-1664.

58. Weitberg, A.B. (1989) Effect of nicotinic acid supplementation in vivo on oxygen radical-induced genetic damage in human lymphocytes. Mutat. Res., 216, 197-201.

59. Satoh, M.S., Poirier, G.G., Lindahl, T., (1993) NAD ${ }^{+}$-dependent repair of damaged DNA by human cell extracts. J. Biol. Chem., 268, 5480-5487.

60. Molinete, M., Vermeulen, W., Bürkle, A., Ménissier-de Murcia, J., Küpper, J.H., Hoeijmakers, J.H.J. de Murcia, G. (1993) Overproduction of the poly(ADP-ribose) polymerase DNA-binding domain blocks alkylation-induced DNA repair synthesis in mammalian cells. EMBO J., 12, 2109-2117.

61. King, H.W.S., Osborne, M.R., Brookes, P. (1979) The in vitro and in vivo reaction at the N7-position of guanine of the ultimate carcinogen derived from benzo[a]pyrene. Chem. Biol. Interact., 24, 345-353.

62. Kaufmann, W.K., Boyer, J.C., Smith, B.A., Cordeiro-Stone, M. (1985) DNA repair and replication in human fibroblasts treated with $( \pm)-r-7, t-8$-hihydroxy-t-9,10-epoxy- 
7,8,9,10-tetrahydrobenzo[a]pyrene. Biochim. Biophys. Acta, 824, 146-151.

63. Cordiero-Stone, M., Boyer, J.C., Smith, B.A., Kaufmann, W.K. (1986) Effect of benzo[a]pyrene-diol-epoxide-I on growth of nascent DNA in synchronized human fibroblasts. Carcinogenesis, 7, 1775-1781.

64. Shah, G.M., Bhattacharya, R.K. (1992) Modulation of transcription in rat liver nuclei in vitro by a diol epoxide of benzo[a]pyrene. J. Biochem. Toxicol., 7, 1317. 
Effect of nicotinic acid supplementation on niacin status in relation to cytogenetic damage and ex vivo ( \pm )-antibenzo[a]pyrene diolepoxide-induced DNA repair in smoking humans

R.H. Stierum, G.J. Hageman, M.H.M. van Herwijnen, M.S.E. van der Veer, A.P.H. Vankan and J.C.S. Kleinjans

Department of Health Risk Analysis and Toxicology, University of Limburg, P.O. Box 616, 6200 MD Maastricht, The Netherlands

Based on a manuscript submitted to: Cancer Epidemiology, Biomarkers and Prevention

\begin{abstract}
One of the processes supposed to be involved in DNA repair is poly(ADPribosylation). In response to DNA strand breaks, the enzyme poly(ADP-ribose) polymerase catalyzes the rapid transfer of ADP-ribose moieties from nicotinamide adenine dinucleotide $\left(\mathrm{NAD}^{+}\right)$to poly(ADP-ribose) polymers. As a consequence of extensively occurring damage, intracellular $\mathrm{NAD}^{+}$is depleted. Since niacin is a precursor of $\mathrm{NAD}^{+}$, it has been proposed that nutritional niacin intake influences poly(ADP-ribosylation) and thus poly(ADP-ribosylation)dependent DNA repair. Sub-optimal niacin intake may therefore be a risk factor in carcinogenesis. The purpose of this study was to investigate whether nicotinic acid supplementation of healthy human smokers can be effective in reducing in vivo cytogenetic damage caused by cigarette smoking, as a consequence of an improved niacin status and DNA repair. Supplementation of human male smokers with nicotinic acid in doses of $50-100 \mathrm{mg} /$ day during 14 weeks resulted in elevated blood nicotinamide levels and moderately increased lymphocytic $\mathrm{NAD}^{+}$levels. Frequencies of sister chromatid exchanges (SCE) were increased in the individuals receiving nicotinic acid. However, no significant correlations were found between alterations in lymphocytic $\mathrm{NAD}^{+}$levels or blood nicotinamide levels, and alterations in mean SCE frequencies. No distinct positive or negative effect of nicotinic acid intake on the frequency of
\end{abstract}


hypoxanthine guanine phosphoribosyltransferase variants and micronuclei, or on the degree of ex vivo ( \pm )- $7 \beta, 8 \alpha$-dihydroxy- $9 \alpha, 10 \alpha$-epoxy-7,8,9,10tetrahydrobenzo[a]pyrene-induced DNA repair, as indicated by poly(ADPribosylation) and ( \pm )-anti-BPDE- $\mathrm{N}^{2}$-deoxyguanosine adduct removal, was found.

It is concluded that supplementation of human male smokers with nicotinic acid at doses higher than $50 \mathrm{mg} /$ day is moderately effective in improving niacin status. Nicotinic acid intake resulted in elevated sister chromatid exchanges, but this was not related dose-dependently to alterations in niacin status and does therefore not likely modulate poly(ADP-ribosylation)-dependent repair of smoking-induced DNA damage. In conclusion, no evidence was found for a beneficial effect of nicotinic acid supplementation in healthy humans on mutagenesis and micronuclei formation in vivo, as caused by cigarette smoking.

\section{Introduction}

The introduction of mutations into DNA is considered to represent one of the first steps in carcinogenesis. Formation of mutations may be caused by lesions, induced by exposure to genotoxic chemicals and physical agents like radiation, or by endogenous mutagens such as reactive oxygen species, formed during normal metabolic processes (1). Cells possess various DNA repair systems which enable them to restore the integrity of their genetic material constantly, thereby preventing the onset of mutagenesis.

One of these processes, actively involved in DNA repair, is poly(ADPribosylation). This nuclear, enzymatic process is catalyzed by the enzyme poly(ADP-ribose) polymerase (NAD+ $\mathrm{ADP}^{+}$-ribosyltransferase, E.C. 2.4.2.30), which transfers the adenosine diphosphate ribose units from intracellular $\mathrm{NAD}^{+}$to linear and branched poly(ADP-ribose) polymers. Consequently, intracellular $\mathrm{NAD}^{+}$is depleted. In recent years, considerable work has been done to elucidate in vitro and ex vivo the action of poly(ADP-ribosylation) in relation to DNA repair mechanisms. Thus, it is known that DNA strand breaks are required for enzyme activation (2-4) and it has been proposed that the accessibility of damaged DNA for other repair enzymes is transiently improved by poly(ADP-ribosylation) via modification of histone-DNA interactions $(5,6)$. Recently, it was suggested that poly(ADP-ribose) polymerase is involved only in the process of base excision repair, during which the enzyme, temporarily bound to DNA strand breaks, might protect DNA against recombinational events (7-9).

Little is known about the role of poly(ADP-ribosylation) in human carcinogenesis in general, and in particular with respect to the recovery from DNA damage in vivo. It may be hypothesized that poly(ADP-ribosylation) is impaired if intracellular $\mathrm{NAD}^{+}$is decreased, as a consequence of sub-optimal niacin intake. Weitberg (10) showed that blood lymphocytic $\mathrm{NAD}^{+}$levels are 
elevated after supplementation of two healthy human volunteers with $100 \mathrm{mg}$ nicotinic acid per day during 8 weeks. In lymphocytes obtained from these persons, the occurrence of ex vivo oxygen-radical induced DNA strand breaks was lower than in lymphocytes obtained from non-supplemented persons.

The aims of the present study were two-fold; to investigate whether nicotinic acid intake reduces DNA damage in healthy smoking humans, as a function of improved endogenous niacin status and improved DNA repair as well as to investigate whether correlations exist between markers of ex vivo ( \pm )-antiBPDE-induced DNA repair processes and biomarkers of cytogenetic damage, reflecting endogenous DNA damage. Smoking male persons were supplemented with nicotinic acid during 14 weeks. Alterations in niacin status were monitored by determination of levels of two main nicotinic acid metabolites, e.g. nicotinamide in blood and $\mathrm{NAD}^{+}$in peripheral blood lymphocytes (PBLs). As indicators for DNA repair activity, changes in poly(ADP-ribose) polymer metabolism and $\left( \pm\right.$ )-anti-BPDE- $\mathrm{N}^{2}-\mathrm{dG}$ adduct removal in peripheral blood lymphocytes were determined after ex vivo treatment with ( \pm )-7 $\beta, 8 \alpha$-dihydroxy$9 \alpha, 10 \alpha$-epoxy-7,8,9,10-tetrahydrobenzo[a]pyrene (( \pm -anti-BPDE). To evaluate whether DNA damage is affected by nicotinic acid intake, sister chromatid exchanges, hypoxanthine guanine phosphoribosyltransferase (hprt) variant frequencies and micronuclei $(\mathrm{MN})$ frequencies were determined in peripheral blood lymphocytes, prior to and at the end of the nicotinic acid supplementation period.

\section{Materials and methods}

\section{Materials}

All chemicals were purchased from Merck Europe, unless otherwise specified. Cell culture media and supplements were obtained from Gibco Europe, Breda, The Netherlands.

\section{Study population}

21 healthy male human smokers, smoking at least 10 cigarettes per day, were included into this study, which was performed from April 1993 till September 1993. Data on age, weight, length, alcohol and coffee consumption, smoking habits and use of medication were obtained using a standard questionnaire. The characteristics of the subjects are shown in Table 4.1.

\section{Nicotinic acid supplementation and measurement schedule}

In order to study whether dose-dependent effects of nicotinic acid intake on parameters of DNA damage and repair occur, subjects were divided into several dose groups as shown in Table 4.1. The $50 \mathrm{mg} /$ day dose group consisted of 3 individuals receiving $1 \times 50 \mathrm{mg} /$ day and 3 individuals receiving $3 \times 16.7 \mathrm{mg} /$ day, in order to study the possible effect of daily intake frequencies. In order to reduce 
Table 4.1. Characteristics of the study population.

\begin{tabular}{lllll}
\hline $\begin{array}{l}\text { nicotinic acid intake } \\
\text { (mg/day) }\end{array}$ & $\begin{array}{l}0 \\
(\mathrm{n}=6)\end{array}$ & $\begin{array}{l}25 \\
(\mathrm{n}=3)\end{array}$ & $\begin{array}{l}50 \\
(\mathrm{n}=6)\end{array}$ & $\begin{array}{l}100 \\
(\mathrm{n}=6)\end{array}$ \\
\hline $\begin{array}{l}\text { age } \\
\quad \text { (years) }\end{array}$ & $31.8 \pm 13.1$ & $42.0 \pm 9.5$ & $36.2 \pm 9.2$ & $28.3 \pm 9.1$ \\
$\begin{array}{l}\text { smoking habit } \\
\quad \text { (cigarettes/day) }\end{array}$ & $18.8 \pm 8.9$ & $21.6 \pm 2.8$ & $19.7 \pm 3.3$ & $18.5 \pm 5.8$ \\
$\begin{array}{l}\text { pack years } \\
\quad \text { (packs of cigarettes smoked/day }\end{array}$ & $11.7 \pm 8.4$ & $28.0 \pm 7.2$ & $15.7 \pm 8.7$ & $8.6 \pm 7.6$ \\
$\begin{array}{l}\text { * smoking years) } \\
\text { alcohol consumption } \\
\quad \text { (glasses/week) } \\
\text { coffee consumption } \\
\quad \text { (cups/day) }\end{array}$ & $10.8 \pm 5.9$ & $14.3 \pm 14.0$ & $11.2 \pm 11.9$ & $14.2 \pm 8.0$ \\
\hline
\end{tabular}

determination of $\mathrm{NAD}^{+}$ levels in lymphocytes and blood nicotinamide levels, every two weeks

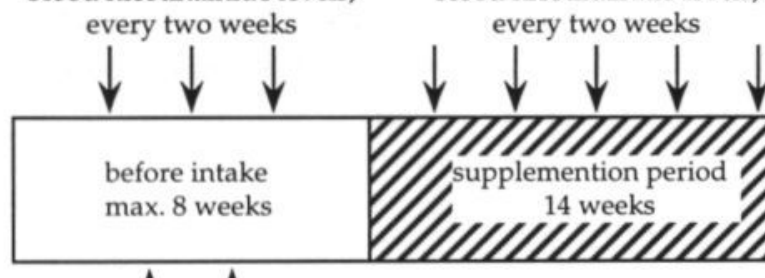

determination of $\mathrm{NAD}^{+}$ levels in lymphocytes and blood nicotinamide levels, determination of $\mathrm{NAD}^{+}$ levels in lymphocytes and blood nicotinamide levels, determination of SCE, MN, VF, ( \pm )-anti-BPDE-induced poly(ADP-ribosylation),

( \pm )-anti-BPDE-induced adductremoval

\section{every two weeks}


expected to be long enough to detect measurable changes in the degree of in vivo DNA damage. It has been shown that nicotinic acid supplementation of humans during 8 weeks already resulted in a maximum elevation of lymphocytic $\mathrm{NAD}^{+}$levels (10).

In Figure 4.1, the experimental design is outlined. In the 8 weeks before nicotinic acid intake, ( \pm )-anti-BPDE-induced poly(ADP-ribosylation), ( \pm )-antiBPDE-induced adduct removal, sister chromatid exchange frequencies (SCE), hprt variant frequencies (VF), and micronuclei frequencies were determined in a sample of peripheral blood lymphocytes, twice for each individual. Also, on at least two different days during the pre-supplementation period, the levels of the main nicotinic acid metabolites, nicotinamide and $\mathrm{NAD}^{+}$, were determined in blood and isolated lymphocytes respectively, to assess niacin status before nicotinic acid administration. In order to monitor niacin status during the supplementation period, every two weeks blood nicotinamide levels and lymphocytic $\mathrm{NAD}^{+}$levels were determined for each individual. Finally, at the end of nicotinic acid supplementation, blood nicotinamide levels, lymphocytic $\mathrm{NAD}^{+}$levels and SCE, MN, VF and parameters of ( \pm )-anti-BPDE-induced DNA repair were again determined at two different time points.

Participants were informed about possible side effects of nicotinic acid intake and all persons officially agreed to participate to this study by giving their written informed consent. The study protocol was approved by the Medical Ethical Commission of the University of Limburg, Maastricht, The Netherlands.

\section{Determination of $\mathrm{NAD}^{+}$levels in isolated peripheral blood lymphocytes}

Within $2 \mathrm{~h}$ after collection of the blood sample, $10 \mathrm{ml}$ of blood were diluted by an equal volume of phosphate buffered saline and layered onto $3 / 4$ volume of Lymphoprep $^{\mathrm{TM}}$ (Nycomed, Oslo, Norway) in $50 \mathrm{ml}$ culture tubes, prior to centrifugation during $20 \mathrm{~min}$ at $800 \mathrm{~g}$. Interphases containing PBLs, were collected, pooled in $50 \mathrm{ml}$ culture tubes and washed twice with PBS. Cells were counted, using a haemocytometer and dissolved in RPMI 1640 medium to a final density of $100 \times 10^{6}$ cells $/ \mathrm{ml}$. Then, $60 \mu \mathrm{l}$ of cell suspension were resuspended in $540 \mu \mathrm{l}$ of ice cold RPMI 1640 medium in $10 \mathrm{ml}$ tubes, in duplicate, and $100 \mu \mathrm{l}$ of this solution were stored at $-20^{\circ} \mathrm{C}$ for protein determination. Subsequently, pyridine nucleotides were extracted with $2 \mathrm{ml}$ ice-cold $0.1 \mathrm{M} \mathrm{NaOH}, 1 \mathrm{mM}$ nicotinamide (Sigma, Axel, The Netherlands) followed by a $1 \mathrm{ml}$ wash of the tube. The period of time between withdrawal of blood samples and extraction procedure was held as constant as possible. Then, samples were neutralized with $0.37 \mathrm{M} \mathrm{H}_{3} \mathrm{PO}_{4}$, to $\mathrm{pH} 7.3$ and stored at $-20^{\circ} \mathrm{C}$. For determination of intracellular $\mathrm{NAD}^{+}$levels, an enzymatic cycling assay was applied (11). Frozen extracts were thawed and reduced pyridine nucleotides in the extract were oxidized by addition of $200 \mu \mathrm{l}$ of $2.0 \mathrm{mM}$ phenazine ethosulfate (Sigma, Axel, The Netherlands). An aliquot of $200 \mu \mathrm{l}$ of the extract (or standard NAD ${ }^{+}$in bidest, Sigma, Axel, The Netherlands) was added in duplicate to a preincubated reaction mixture, 
containing final concentrations of $1.67 \mu \mathrm{mol} / \mathrm{ml}$ phenazine ethosulfate, 0.42 $\mu \mathrm{mol} / \mathrm{ml} \mathrm{3-[4,5-dimethylthiazol-2-yl]-2,5-diphenyl-2H-tetrazolium} \mathrm{bromide,} 60$ $\mu \mathrm{mol} / \mathrm{ml}$ bicin $\mathrm{pH} 7.8,0.167 \mathrm{mg} / \mathrm{ml}$ alcoholdehydrogenase (all from Sigma, Axel, The Netherlands) and $0.5 \mu \mathrm{mol} / \mathrm{ml}$ ethanol, and incubated for exactly $30 \mathrm{~min}$ at $30{ }^{\circ} \mathrm{C}$. Absorption of the reaction mixture was measured at $570 \mathrm{~nm}$ immediately after incubation, at room temperature, using a Beckman DU 648 spectrophotometer.

\section{Protein determination}

Frozen samples were thawed and in order to dissolve the cellular material, an equal volume of $0.2 \%$ sodium dodecylsulfate (SDS) was added and samples were mixed vigorously for at least $30 \mathrm{~min}$. Then, $20 \mu \mathrm{l}$ of the dissolved material were added to $780 \mu \mathrm{l}$ bidest and protein was determined, using the Bio-Rad ${ }^{\mathrm{TM}}$ (BioRad, Europe) protein assay kit. Standard bovine serum albumine (BSA) solutions were prepared in $2.5 * 10^{-3} \%$ SDS, which did not interfere with the linearity of the calibration curve.

\section{Determination of nicotinamide in venous heparinized blood}

Nicotinamide levels in venous heparinized blood were determined according to the procedure developed by Shibata et al. (12). Blood samples were collected according to the experimental design (Figure 4.1) and stored at $-20{ }^{\circ} \mathrm{C} .300 \mu \mathrm{l}$ of blood were added to $1700 \mu \mathrm{l}$ of bidest in glass tubes, in duplicate. $10 \mu \mathrm{l}$ of 1.0 $\mathrm{mg} / \mathrm{ml}$ 1-methylnicotinamide (Sigma, Axel, The Netherlands) [C.A.S. \#: 114-330] as internal standard were added and samples were heated at $100{ }^{\circ} \mathrm{C}$ for $10 \mathrm{~min}$. Subsequently, samples were cooled on ice during $10 \mathrm{~min}$ and $1500 \mu \mathrm{l}$ were transferred to Eppendorf vials, and centrifuged at $4{ }^{\circ} \mathrm{C}$ at $1200 \mathrm{rpm}$ during $30 \mathrm{~min}$. The supernatant was filtered through a $0.45 \mu \mathrm{M}$ filter and $500 \mu \mathrm{l}$ were added to $600 \mathrm{mg} \mathrm{KCO} 3$ on ice. Tubes were vortexed and subsequently incubated at room temperature during $5 \mathrm{~min}$. Then, samples were three times extracted with $2.5 \mathrm{ml}$ of diethyl ether. Pooled diethylether fractions were evaporated under nitrogen at room temperature and the residue was dissolved in $500 \mu \mathrm{l}$ of bidest. Nicotinamide and 1-methylnicotinamide were separated on a Supelco supelcosil/ ${ }^{\mathrm{TM}}$ LC- $18 \mathrm{~S}$ column $(250 \times 4.6$ i.d.). The injection volume was $100 \mu \mathrm{l}$. The column was eluted isocratically at a flow rate of $1.00 \mathrm{ml} / \mathrm{min}$ at room temperature with $97 \% 10 \mathrm{mM} \mathrm{KH}_{2} \mathrm{PO}_{4}, 2.5 \%$ acetonitril, $0.5 \%$ tetrahydrofurane $(\mathrm{v} / \mathrm{v} / \mathrm{v}) \mathrm{pH} 4.5$, delivered by a Kratos Spectroflow 400 solvent delivery system. Monitoring of nicotinamide (and 1-methylnicotinamide) was performed at 260 $\mathrm{nm}$, using a Waters 994 programmable photodiode array detector. The detection limit of nicotinamide was $0.05 \mu \mathrm{g}$ absolute, corresponding to approximately 3.3 $\mu \mathrm{g}$ nicotinamide $/ \mathrm{ml}$ blood. Overall recoveries of $80-90 \%$ were obtained. 


\section{Determination of ( \pm )-anti-BPDE induced poly(ADP-ribosylation)}

In a previous study, we showed that $( \pm)$-anti-BPDE treatment of PHA-stimulated lymphocytes during 15 minutes resulted in elevated levels of ethenoribosyladenosine ( $\varepsilon$ Rado), the unique nucleoside derived from poly(ADPribose) (13), which increased further upon prolonged treatment (14). According to the experimental design (Figure 4.1), $110 \mathrm{ml}$ venous heparinized blood were diluted by an equal volume of phosphate buffered saline and lymphocytes were isolated as described above for determination of $\mathrm{NAD}^{+}$levels. Next, cells were incubated at $37^{\circ} \mathrm{C}$ at a density of $10 \times 10^{6}$ cells/ml RPMI 1640 medium with 40 $\mu \mathrm{M}( \pm$ )-anti-BPDE (Midwest Research Institute, Missouri, USA) (final concentration DMSO: $0.18 \%$ ). After 15 minutes, half of the cell suspension was added to an equal volume of ice-cold $40 \%$ trichloroacetic acid (TCA) and incubated on ice for at least 30 minutes. $100 \mu \mathrm{l}$ of cell suspension were used for protein determination, prior to TCA precipitation. The other half of the cell suspension was incubated for another 20 minutes and subsequently TCAprecipitated. TCA-insoluble material from both time points (at 15 and 35 minutes) was pelleted by centrifugation at $3600 \mathrm{rpm}$, during 15 minutes at $4{ }^{\circ} \mathrm{C}$. Pellets were stored at $-20{ }^{\circ} \mathrm{C}$ prior to determination of $\varepsilon$ Rado, according to the procedure of Jacobson (13) with minor modifications as described elsewhere (14), except that [adenine- $\left.{ }^{14} \mathrm{C}\right]$ poly(ADP-ribose) was obtained from permeabilized lymphocytes.

\section{Determination of ( \pm )-anti-BPDE- $N^{2}-d G$ adduct removal}

According to the experimental design, $40 \mathrm{ml}$ of blood were diluted with an equal volume of PBS and lymphocytes were isolated as described. Cells were resuspended in RPMI 1640 medium at a density of $10 \times 10^{6}$ cells $/ \mathrm{ml}$ and incubated for $15 \mathrm{~min}$ at $37{ }^{\circ} \mathrm{C}$ with $0.5 \mu \mathrm{M}( \pm)$-anti-BPDE. Half of the cell suspension was diluted ten-fold in RPMI 1640 complete medium in culture flasks (final conc. FCS 15\%) and cultured for $24 \mathrm{~h}(\mathrm{~T}=24 \mathrm{~h}$ ). The other part of the suspension $(T=0 \mathrm{~h})$ was centrifuged, medium was discarded and the pellet was dissolved in $1 \mathrm{ml} 5 \%$ SDS and incubated with $136 \mu \mathrm{g} / \mathrm{ml}$ RNase A and $18 \mathrm{U} / \mathrm{ml}$ RNase T1 (both from Boehringer Mannheim) for 30 minutes at $37{ }^{\circ} \mathrm{C}$. Samples were digested overnight with $4.0 \mathrm{ml}$ of $50 \mu \mathrm{g} / \mathrm{ml}$ proteinase- $\mathrm{K}$ in $75 \mathrm{mM} \mathrm{NaCl}, 25$ mM EDTA. DNA was extracted as described elsewhere (15) and ( \pm )-anti-BPDE$\mathrm{N}^{2}$-dG adduct levels were determined using standard adduct labeling, according to the procedure of Reddy et al. (16). Chromatograms were visualized and quantified using a Molecular Dynamics Phosphor Imager with Image Quant ${ }^{\mathrm{TM}}$ software. The extent of ( \pm )-anti-BPDE- $\mathrm{N}^{2}$-dG adduct removal was calculated as follows:

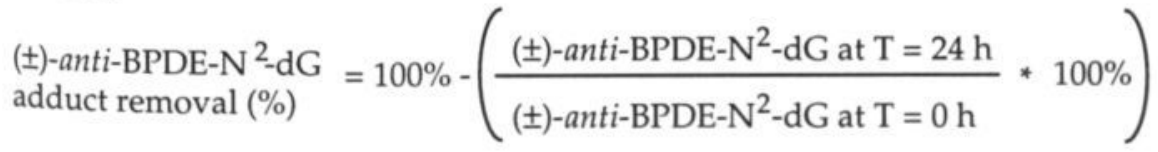




\section{Determination of sister chromatid exchange frequencies}

SCE frequencies in human peripheral blood lymphocytes were determined as described previously (17). According to the experimental design, outlined in Figure $4.1,0.4 \mathrm{ml}$ of blood were added to $5.0 \mathrm{ml}$ of RPMI 1640 medium, supplemented with $10 \%$ foetal calf serum (FCS), $100 \mu \mathrm{g} / \mathrm{ml}$ streptomycin, 100 $\mathrm{U} / \mathrm{ml}$ penicillin, $5 \mathrm{mM}$ L-glutamine, $50 \mathrm{U} / \mathrm{ml}$ heparin (RPMI 1640 complete medium). $0.2 \mathrm{ml}$ of phytohemagglutinin (PHA) were added (final concentration: $52 \mu \mathrm{g} / \mathrm{ml}$ ) and cells were cultured for $24 \mathrm{~h}$ at $37^{\circ} \mathrm{C}$ as described above. Bromodeoxyuridine (BrdU) (Serva, Europe) was added (final concentration: 58 $\mu \mathrm{M})$ and cultures were incubated for another $48 \mathrm{~h} .1 \mathrm{~h}$ prior to harvesting, $100 \mu \mathrm{l}$ of colcemid were added. Then, cells were hypotonized in $75 \mathrm{mM} \mathrm{KCl}$ for $10-15$ min and fixed with methanol : acetic acid $(3: 1 ; \mathrm{v} / \mathrm{v})$. Metaphase slides were prepared and were stained by means of the Hoechst-plus-Giemsa technique (18). Before microscope evaluation, the slides were encoded. Slides were evaluated by a well-trained observer, and SCE scores were checked by a second independent observer. From one person, - for each time point, at least 20 metaphases, containing 40 chromosomes as a minimum, were analyzed for SCEs.

\section{Determination of in vivo hprt variant frequencies}

In vivo induced hprt variant frequencies in peripheral blood lymphocytes were analyzed by assessment of 6-thioguanine resistance (TGr), according to the procedure developed by Hageman et al. (19). $5 \mathrm{ml}$ of venous heparinized blood was diluted tenfold in RPMI 1640 medium, and stored for $24 \mathrm{~h}$ at $4{ }^{\circ} \mathrm{C}$ to inhibit the confounding effect of possible spontaneously cycling lymphocytes. Then, cells were collected by centrifugation and part of the cells was divided into eight cultures, in such a way that each culture contained the equivalent of $0.5 \mathrm{ml}$ whole blood, $5.0 \mathrm{ml}$ RPMI complete medium, $0.2 \mathrm{ml}$ PHA (final concentration: \pm $52 \mu \mathrm{g} / \mathrm{ml}$ ), and $2 \times 10^{-4} \mathrm{M}$ 6-thioguanine (TG) (Sigma, Axel, The Netherlands). To determine the labeling index of the TG control cultures (LIc), two cultures were set up, containing RPMI 1640 complete medium, without TG. After culturing for $24 \mathrm{~h}$ at $37^{\circ} \mathrm{C}$, BrdU was added to a final concentration of $1 \times 10^{-5} \mathrm{M}$. After an additional $16 \mathrm{~h}$ of culturing, cells were hypotonized in $75 \mathrm{mM} \mathrm{KCl}$ and harvested as described above for determination of sister chromatid exchanges. During harvesting, four TG cultures were pooled and cells were finally resuspended in 200-300 $\mu \mathrm{l}$ of fixative. Special care was taken to avoid contamination of TG cultures by BrdU-labeled cells from control cultures. Microscope slides were prepared, containing the material of the TG cultures or two drops of 10-25 $\mu \mathrm{l}$ of the control cultures. The number of nuclei in the TG cultures was counted in triplicate in $1 \mu \mathrm{l}$ of a 1:10 dilution on a microscope slide after Giemsa staining (BDH, Poole, Dorset, UK). For staining and scoring of the slides containing BrdUlabeled cells, DNA was denaturated by incubating the slides during $25 \mathrm{~min}$ in $4 \mathrm{~N}$ $\mathrm{HCl}$. Then, slides were rinsed twice during $10 \mathrm{~min}$ in $0.1 \mathrm{~N}$ Borax buffer, $\mathrm{pH} 8.5$ 
and once in PBS, pH 7.4. After rinsing, the slides were incubated for $1 \mathrm{~h}$ in a humidified atmosphere, with mouse monoclonal anti-BrdU IgG antibodies (a generous gift from Dr. Bert Schutte, Department of Molecular Cell Biology, University of Limburg, The Netherlands), diluted in PBS, containing $1 \%$ BSA and subsequently rinsed twice in PBS. Next, slides were incubated with peroxidase-conjugated rabbit anti-mouse IgG antibodies (RAMPO, P161, Dakopatts, Glostrup, Denmark) and BrdU-labeled nuclei were stained brown by incubating the slides for $10 \mathrm{~min}$ in the dark in a 3,3'-diaminobenzidine (Fluka Chemie, Buchs, Switzerland) solution in $0.05 \mathrm{M}$ Tris- $\mathrm{HCl}, \mathrm{pH} 7.6$ containing $0.01 \%(\mathrm{w} / \mathrm{v}) \mathrm{H}_{2} \mathrm{O}_{2}$. The number of brown nuclei on TG slides was counted using normal light microscopy, with magnification of 400x. The labeling index of the TG cultures (LIt) was calculated as the number of BrdU-containing (brown) nuclei on all TG slides divided by the total number of nuclei on the TG slides. TG control slides were counterstained with Giemsa and the labeling index (LIc) was determined as the number of brown nuclei per 1000 nuclei in the TG control culture, the total number of nuclei evaluated for determination of the LIc was 2000. The VF of TGr lymphocytes was calculated as LIt/LIc. Slides were encoded prior to microscopic analysis, and scored by a well-trained observer.

\section{Determination of micronuclei frequencies}

Before and at the end of nicotinic acid supplementation, the micronuclei frequencies were determined twice using the assay of Fenech and Morley (20). 0.4 $\mathrm{ml}$ of venous heparinized blood were cultured in $5 \mathrm{ml}$ RPMI 1640 complete medium and $0.2 \mathrm{ml}$ PHA (final concentration: $\pm 52 \mu \mathrm{g} / \mathrm{ml}$ ), to stimulate T-cell proliferation. To block cytokinesis, $44 \mathrm{~h}$ after culturing, cytochalasin B (Sigma, Axel, The Netherlands) was added to a final concentration of $6 \mu \mathrm{g} / \mathrm{ml}$. After an additional culture period of $28 \mathrm{~h}$, cultures were harvested as described above and slides were prepared and stained with $3 \%$ Giemsa for $20 \mathrm{~min}$. Prior to microscopic analysis, slides were encoded. Per individual, for each time point, 1000 binucleated cells were analyzed for the presence of micronuclei by a welltrained observer and checked by a second observer.

\section{Statistical analysis}

Possible differences between parameters of DNA repair, DNA damage and parameters of niacin status before and at the end of the nicotinic acid supplementation period were statistically analyzed by means of the nonparametric Wilcoxon signed rank test. Possible correlations between nicotinic acid intake, changes in parameters of niacin status and changes in parameters of DNA damage and repair were statistically analyzed by means of the nonparametric Spearman's Rank Correlation test. Possible effects of age and smoking habits on parameters of DNA damage and repair, and possible associations between parameters of DNA repair and DNA damage, were statistically analyzed by means of simple and multiple regression. 


\section{Results}

One person (\#7) became ill during the nicotinic acid supplementation period and therefore, results from this person were omitted from the statistical analysis.

For two individuals within the $50 \mathrm{mg} /$ day dose group and for two individuals within the $100 \mathrm{mg} /$ day dose group, a clear increase in lymphocytic $\mathrm{NAD}^{+}$levels (expressed as pmol $* 10^{-2}$ per mg protein) was observed during supplementation. In Figure 4.2 , mean $\mathrm{NAD}^{+}$levels, expressed as $\mathrm{pmol} * 10^{-2} / \mathrm{mg}$ protein, are shown for every dose group, before and at the end of the nicotinic acid supplementation period. Each mean value has been calculated from at least two determinations of lymphocytic $\mathrm{NAD}^{+}$per person. A significant increase in $\mathrm{NAD}^{+}$levels was observed at the end of the nicotinic acid supplementation period in the dose group receiving a total amount of $50 \mathrm{mg}$ nicotinic acid per day (mean $\mathrm{NAD}^{+}$levels are shown for all individuals, receiving either $1 \times 50 \mathrm{mg}$ or 3 x $16.7 \mathrm{mg}$ nicotinic acid/day; Wilcoxon signed rank, $\mathrm{p}<0.05$ ). Further, within the highest dose group and within the group of all individuals receiving nicotinic acid, NAD+ levels tended to be higher at the end of the supplementation period. A positive, nearly significant correlation (Spearman Rank Correlation, $r_{s}=0.43$; $\mathrm{p}=0.063$ ) was observed between daily nicotinic acid intake and differences of mean lymphocytic NAD+-levels from each individual before and at the end of the supplementation period (Table 4.2).

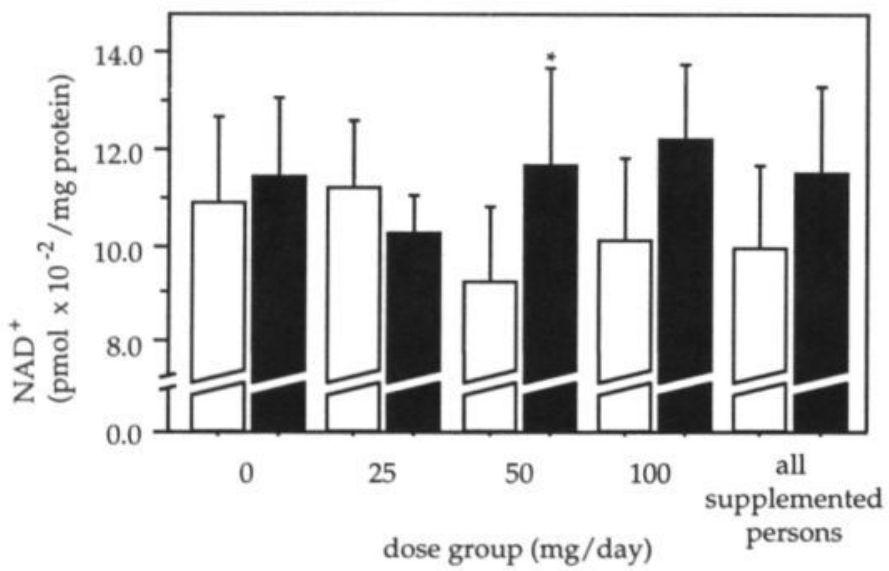

Figure 4.2. NAD ${ }^{+}$levels in isolated human PBLs. Results represent the group mean of $\mathrm{NAD}^{+}$levels, determined before and at the end of the nicotinic acid supplementation period.

- Statistical significant difference between NAD ${ }^{+}$levels before and at the end of the nicotinic acid supplementation period (Wilcoxon signed rank, $\mathrm{p}<0.05$ ). 
Table 4.2. Spearman Rank Correlation coefficients at the individual level between niacin intake, mean differences in niacin status and mean differences in parameters of cytogenetic damage and ( \pm )anti-BPDE-induced DNA repair, before and at the end of the nicotinic acid supplementation period.

\begin{tabular}{|c|c|c|c|c|c|c|}
\hline & $\begin{array}{l}\Delta \text { mean } \\
\mathrm{NAD}^{+}\end{array}$ & $\begin{array}{l}\Delta \text { mean } \\
\text { nicotinamide }\end{array}$ & $\begin{array}{l}\Delta \text { mean } \\
( \pm) \text {-anti-BPDE- } \\
\mathrm{N}^{2} \text {-dG adduct } \\
\text { removal }\end{array}$ & $\begin{array}{l}\triangle \text { mean } \\
\mathrm{SCE}\end{array}$ & $\begin{array}{l}\Delta \text { mean } \\
V F\end{array}$ & $\begin{array}{l}\Delta \text { mean } \\
\mathrm{MN}\end{array}$ \\
\hline $\begin{array}{l}\text { nicotinic acid } \\
\text { intake }\end{array}$ & $\begin{array}{l}r_{s}=0.43 \\
0.05<p<0.10\end{array}$ & $\begin{array}{l}\mathrm{r}_{\mathrm{S}}=0.76 \\
\mathrm{p}<0.001\end{array}$ & $\begin{array}{l}r_{S}=-0.11 \\
\text { N.S. }\end{array}$ & $\begin{array}{l}r_{s}=0.51 \\
p<0.05\end{array}$ & $\begin{array}{l}r_{s}=-0.07 \\
\text { N.S. }\end{array}$ & $\begin{array}{l}r_{s}=-0.08 \\
\text { N.S. }\end{array}$ \\
\hline$\Delta$ mean & -.. & $\mathrm{r}_{\mathrm{S}}=0.23$ & $\mathrm{r}_{\mathrm{S}}=-0.24$ & $r_{s}=0.05$ & $\mathrm{r}_{\mathrm{S}}=0.01$ & $r_{s}=0.14$ \\
\hline $\mathrm{NAD}^{+}$ & & N.S. & N.S. & N.S. & N.S. & N.S. \\
\hline $\begin{array}{l}\Delta \text { mean } \\
\text { nicotinamide }\end{array}$ & $\begin{array}{l}r_{s}=0.23 \\
\text { N.S. }\end{array}$ & $\cdots$ & $\begin{array}{l}r_{s}=-0.08 \\
\text { N.S. }\end{array}$ & $\begin{array}{l}r_{\mathrm{s}}=0.33 \\
\text { N.S. }\end{array}$ & $\begin{array}{l}r_{s}=-0.07 \\
\text { N.S. }\end{array}$ & $\begin{array}{l}r_{\mathrm{s}}=0.11 \\
\text { N.S. }\end{array}$ \\
\hline
\end{tabular}

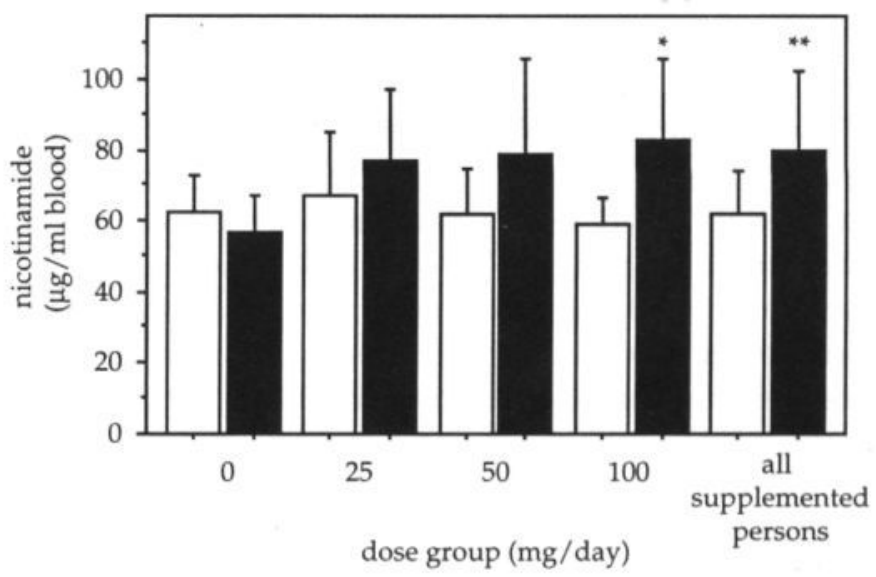

Figure 4.3. Nicotinamide levels in venous heparinized blood samples. Results represent the group mean of nicotinamide levels, determined before and at the end of the nicotinic acid supplementation period.

* Statistical significant difference between nicotinamide levels before and at the end of the nicotinic acid supplementation period (Wilcoxon signed rank, $\mathrm{p}<0.05$ ).

** Statistical significant difference between nicotinamide levels before and at the end of the nicotinic acid supplementation period (Wilcoxon signed rank, $\mathrm{p}<0.01$ ).

At the individual level, an increase in blood nicotinamide level was observed during the supplementation period in 9 of the 11 individuals receiving a total amount of 50 or $100 \mathrm{mg}$ nicotinic acid per day. In Figure 4.3, mean blood nicotinamide levels are shown for all dose groups, before and at the end of the supplementation period. While blood nicotinamide levels tended to decrease in 
the placebo group, in all the groups receiving nicotinic acid, mean nicotinamide blood levels were higher at the end of the supplementation period, with a significant increase in the dose group receiving $100 \mathrm{mg} /$ day (Wilcoxon signed rank, $\mathrm{p}<0.05)$. Also, when individual mean nicotinamide blood levels were averaged for all supplemented persons, a significant increase was observed between mean levels before and at the end of the supplementation period (Wilcoxon signed rank, $\mathrm{p}<0.01$ ). Furthermore, a statistically significant correlation was observed between daily nicotinic acid intake and differences of mean nicotinamide levels from each individual before and at the end of the supplementation period (Spearman Rank Correlation, $\mathrm{r}_{\mathrm{s}}=0.76, \mathrm{p}<0.001$ ) (Table 4.2).

In Figure 4.4, mean $\varepsilon$ Rado levels, determined after $e x$ vivo exposure of lymphocytes to ( \pm )-anti-BPDE for 15 and 35 minutes, before and at the end of the nicotinic acid supplementation period, are shown. For 12 individuals, sufficient cell material for $\varepsilon$ Rado analysis was available. While mean $\varepsilon$ Rado levels for 3 individuals in the placebo group tended to be lower at the end of the supplementation period, no differences were observed in mean $\varepsilon$ Rado levels before and at the end of the supplementation period within the groups receiving nicotinic acid.

In Table 4.3 mean group values of ( \pm )-anti-BPDE- ${ }^{2}-\mathrm{dG}$ adduct removal are shown, determined before and at the end of intake after ex vivo exposure of lymphocytes to $( \pm)$-anti-BPDE. High intra- and inter-individual differences were observed in the extent of $( \pm)$-anti-BPDE- $\mathrm{N}^{2}$-dG adduct removal and in some individuals, lymphocytic adduct levels even accumulated after cessation of $( \pm)$ anti-BPDE exposure. No significant differences were observed in any of the dose groups between mean rate of $\left( \pm\right.$ )-anti-BPDE- $\mathrm{N}^{2}-\mathrm{dG}$ adduct removal before and at the end of the nicotinic acid supplementation period (Wilcoxon signed rank). Nicotinic acid intake and changes in parameters of niacin status for each individual were not significantly correlated with changes in removal of $( \pm)$ anti-BPDE-N2 2 -dG adducts (Table 4.2).

In Table 4.4, results of cytogenetic parameters for each dose group before and at the end of the supplementation period are shown. SCE frequencies tended to increase after supplementation (significantly in the group receiving $100 \mathrm{mg}$ niacin per day, and in all supplemented persons, Wilcoxon signed rank, $\mathrm{p}<0.05$ ), while in the non-supplemented group mean SCE frequencies tended to decrease (Table 4.4). The increase in SCE frequencies within the two highest dose groups, however, was within the control range of SCE frequencies, as determined for the non-supplemented persons. Daily nicotinic acid intake and alterations of mean SCE frequencies for each individual during nicotinic acid supplementation were significantly correlated (Spearman Rank Correlation, $\mathrm{r}_{\mathrm{s}}=0.51, \mathrm{p}<0.05$ ) (Table 4.2). Alterations of mean individual SCE frequencies were not correlated with alterations of mean individual nicotinamide blood levels (see Table 4.2) 


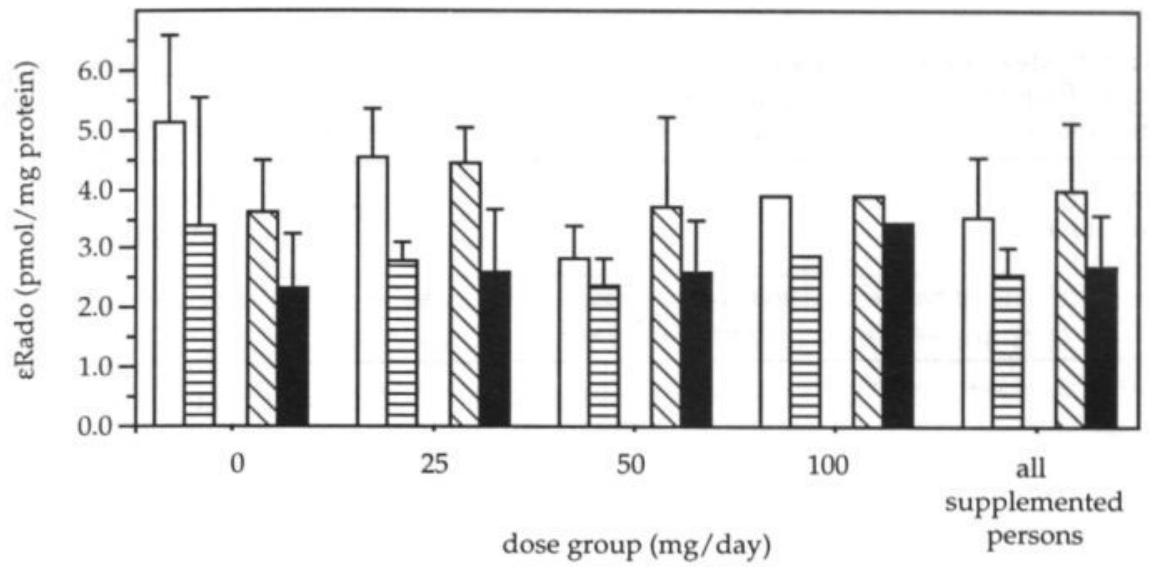

Figure 4.4. Poly(ADP-ribosylation) in isolated PBLs, determined after ex vivo exposure to $40 \mu \mathrm{M}$ $( \pm)$-anti-BPDE. Results represent the group mean levels $( \pm \mathrm{SD})$ of $\varepsilon$ Rado/mg protein, determined before the nicotinic acid supplementation period after $15(\square)$ and 35 ( $\square$ ) minutes of ( \pm )-antiBPDE exposure, and at the end of the nicotinic acid supplementation period after 15 ( $\square$ ) and 35 ( $)$ minutes of ( \pm )-anti-BPDE exposure.

Table 4.3. Mean removal of ( \pm -anti-BPDE- $\mathrm{N}^{2}$-dG adducts in peripheral blood lymphocytes, determined before and at the end of nicotinic acid supplementation period. Group means \pm standard deviations are shown.

dose group

(mg nicotinic

acid/day)
( \pm )-anti-BPDE- $\mathrm{N}^{2}$-dG

adduct removal (\%)

\begin{tabular}{ll}
\hline before & end of \\
intake & intake
\end{tabular}

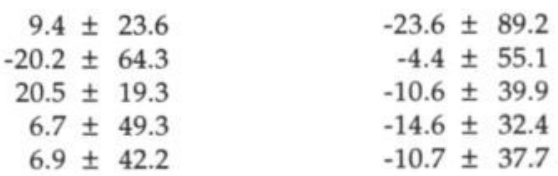

all supplemented

persons

(Spearman Rank Correlation, $\mathrm{r}_{\mathrm{s}}=0.33, \mathrm{p}=0.15$ ). Furthermore, no statistically significant correlation between changes of mean individual SCE frequencies during the supplementation period and changes of mean individual lymphocytic $\mathrm{NAD}^{+}$levels during supplementation was observed.

A significant decrease in mean hprt variant frequencies before and at the end of the supplementation period was observed only within the dose group receiving $100 \mathrm{mg}$ nicotinic acid per day (Wilcoxon signed rank, $\mathrm{p}<0.05$ ). Alterations in lymphocytic $\mathrm{NAD}^{+}$levels (in pmol $* 10^{-2} / \mathrm{mg}$ protein) and blood nicotinamide levels, however, were not significantly correlated with alterations in VF frequencies (see Table 4.2). 
Table 4.4. Mean variant frequencies (VF), micronuclei frequencies (MN) and sister chromatid exchange frequencies (SCE) in peripheral blood lymphocytes, determined before and at the end of the nicotinic acid supplementation period. Group means \pm standard deviations are shown.

\begin{tabular}{|c|c|c|c|c|c|c|}
\hline \multirow{2}{*}{$\begin{array}{l}\text { dose group } \\
\text { (mg nicotinic } \\
\text { acid/day) }\end{array}$} & \multicolumn{2}{|l|}{ SCEs/cell } & \multicolumn{2}{|l|}{$V F+10^{-6}$} & \multicolumn{2}{|c|}{$\begin{array}{l}\text { MN/ } \\
1000 \text { binucleated cells }\end{array}$} \\
\hline & $\begin{array}{l}\text { before } \\
\text { intake }\end{array}$ & $\begin{array}{l}\text { end of } \\
\text { intake }\end{array}$ & $\begin{array}{l}\text { before } \\
\text { intake }\end{array}$ & $\begin{array}{l}\text { end of } \\
\text { intake }\end{array}$ & $\begin{array}{l}\text { before } \\
\text { intake }\end{array}$ & $\begin{array}{l}\text { end of } \\
\text { intake }\end{array}$ \\
\hline 0 & $6.3 \pm 1.1$ & $5.8 \pm 0.9$ & $8.98 \pm 6.94$ & $3.38 \pm 2.53$ & $4.6 \pm 1.7$ & $6.2 \pm 2.6$ \\
\hline 25 & $6.9 \pm 1.0$ & $7.5 \pm 0.2$ & $10.64 \pm 11.24$ & $10.68 \pm 6.77$ & $6.0 \pm 1.0$ & $6.2 \pm 1.8$ \\
\hline 50 & $6.2 \pm 0.7$ & $6.8 \pm 1.3$ & $13.63 \pm 18.46$ & $38.19 \pm 47.54$ & $6.6 \pm 2.2$ & $5.7 \pm 2.2$ \\
\hline 100 & $5.2 \pm 0.6^{*}$ & $6.2 \pm 0.7$ & $16.40 \pm 12.04^{\circ}$ & $3.20 \pm 1.78$ & $4.0 \pm 1.6$ & $4.7 \pm 1.6$ \\
\hline $\begin{array}{l}\text { all supplemented } \\
\text { persons }\end{array}$ & $6.0 \pm 0.9^{*}$ & $6.7 \pm 1.0$ & $13.98 \pm 14.14$ & $19.80 \pm 34.03$ & $5.5 \pm 2.1$ & $5.4 \pm 1.9$ \\
\hline
\end{tabular}

- Statistical significant difference between parameter before and at the end of the nicotinic acid supplementation period (Wilcoxon signed rank, $\mathrm{p}<0.05$ ).

No significant differences were observed between mean micronuclei frequencies in any of the dose groups, measured before and at the end of the nicotinic acid supplementation period. At the individual level, no statistically significant correlations were found between nicotinic acid intake, parameters of niacin status and alterations in $\mathrm{MN}$ frequencies.

No significant correlations were observed between any of the parameters, related to niacin status and cytogenetic damage, versus $( \pm)$-anti-BPDE-induced adduct removal or poly(ADP-ribosylation) before intake. Changes in repair parameters during the supplementation period were not significantly correlated to any changes in parameters of cytogenetic damage.

No effect of smoking was observed on parameters of DNA repair. Further, concerning the effect of smoking on DNA damage, a significant positive correlation was found between the number of pack years and SCE frequencies, determined before the nicotinic acid supplementation period (simple regression, $\mathrm{r}=0.52, \mathrm{p}=0.018$ ). Age also correlated significantly with SCE frequencies (simple regression, $r=0.45, p=0.044)$. The number of packyears and age were significantly correlated (simple regression, $\mathrm{r}=0.77, \mathrm{p}<0.0001$ ). When the correlation between packyears and SCE frequencies was adjusted for age, the positive correlation between pack years and SCE frequencies disappeared; the regression model was only nearly significant (Multiple regression: $R=0.53, p=0.061$; regression equation: SCE frequencies $=(0.011 *$ age $)+(0.043 *$ number of pack years $)+5.095)$.

A positive correlation was found between the number of pack years and logarithmically transformed VF, determined before the nicotinic acid supplementation period (simple regression, $r=0.36, p=0.12$ ), which reached statistical significance after exclusion of two highest VF values. The number of pack years also correlated positively, nearly significant with MN frequencies, determined before the nicotinic acid supplementation period (simple regression, 
$r=0.43, p=0.06$ ). Age, coffee consumption and alcohol consumption did not correlate significantly with logarithmically transformed VF and MN frequencies, determined before nicotinic acid supplementation.

\section{Discussion}

Recently, the possible importance of an individual's niacin status in relation to repair of DNA damage and carcinogenesis has been considered (21). It was proposed that the activity of the DNA repair-related enzyme poly(ADP-ribose) polymerase and consequently the degree of DNA damage occurring in vivo might be very sensitive to fluctuations in cellular $\mathrm{NAD}^{+}$content (21). In rats, niacin deficiency resulted in decreased tissue $\mathrm{NAD}^{+}$levels, decreased hepatic poly(ADP-ribose) polymerase activity $(22,23)$ and increased ex vivo oxygen radical-induced strand breaks formation in hepatocytes and lymphocytes (22). Further, it has been shown that $\mathrm{NAD}^{+}$levels were elevated in blood lymphocytes obtained from two healthy human individuals receiving nicotinic acid during a period of eight weeks, and that these cells were more resistant to $e x$ vivo induced DNA strand break formation (10). Thus, despite the fact that estimated daily niacin-intake (in The Netherlands: at least $14 \mathrm{mg} \mathrm{NE} /$ day (as nicotinic acid); in the USA: $16-34 \mathrm{mg} \mathrm{NE} /$ day) is sufficient to prevent niacindeficiency-related disorders like Pellagra (occurring when intake $<9-12 \mathrm{mg}$ $\mathrm{NE}$ /day) (24), minor alterations in niacin status may modulate carcinogenesis given the potential important role of poly(ADP-ribosylation) in DNA repair. Therefore, the aim of the present study was to investigate whether cytogenetic damage caused by smoking, and its repair in healthy humans was affected by alterations in niacin status, as a consequence of nicotinic acid supplementation.

A positive association was found between smoking habits and parameters of cytogenetic damage in peripheral blood lymphocytes, determined before nicotinic acid supplementation. Supplementation during 14 weeks of human volunteers with nicotinic acid resulted in an elevated niacin status as judged from increases in blood nicotinamide levels and lymphocytic $\mathrm{NAD}^{+}$levels. Mean lymphocytic $\mathrm{NAD}^{+}$levels appeared to be approximately $10-20 \%$ higher at the end of supplementation in comparison to baseline levels, within the $50 \mathrm{mg}$ (statistical significant, $\mathrm{p}<0.05$ ) and $100 \mathrm{mg}$ dose groups, and within the group composed of all individuals receiving nicotinic acid. Not every individual showed an increase in lymphocytic $\mathrm{NAD}^{+}$levels during nicotinic acid supplementation.

It has been shown that both nicotinic acid and nicotinamide can act as precursors for $\mathrm{NAD}^{+}$synthesis in resting lymphocytes in vitro (25). Since in humans, nicotinic acid is nearly completely absorbed in stomach and small intestine (26), increased plasma nicotinic acid levels likely resulted in moderately increased lymphocytic NAD+ levels, via the Preiss-Handler Pathway (see Figure 4.5, pathway I.). Alternatively, via the Preiss-Handler Pathway and subsequent 


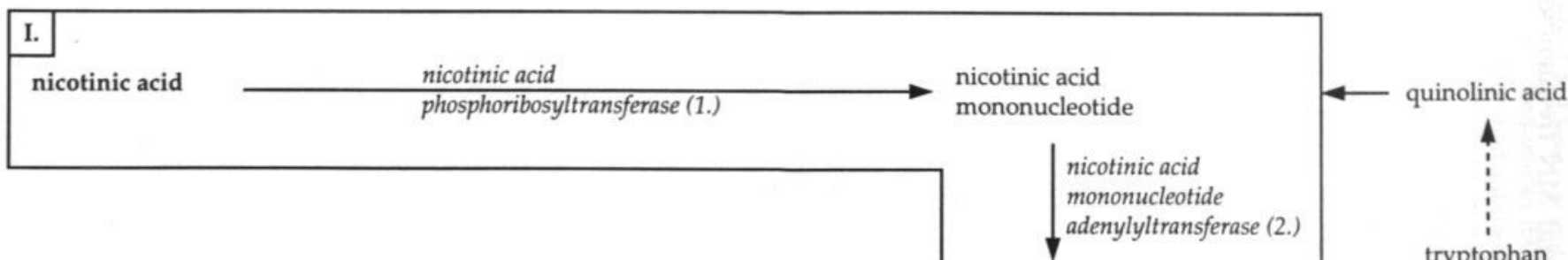

nicotinic acid adenine

dinucleotide
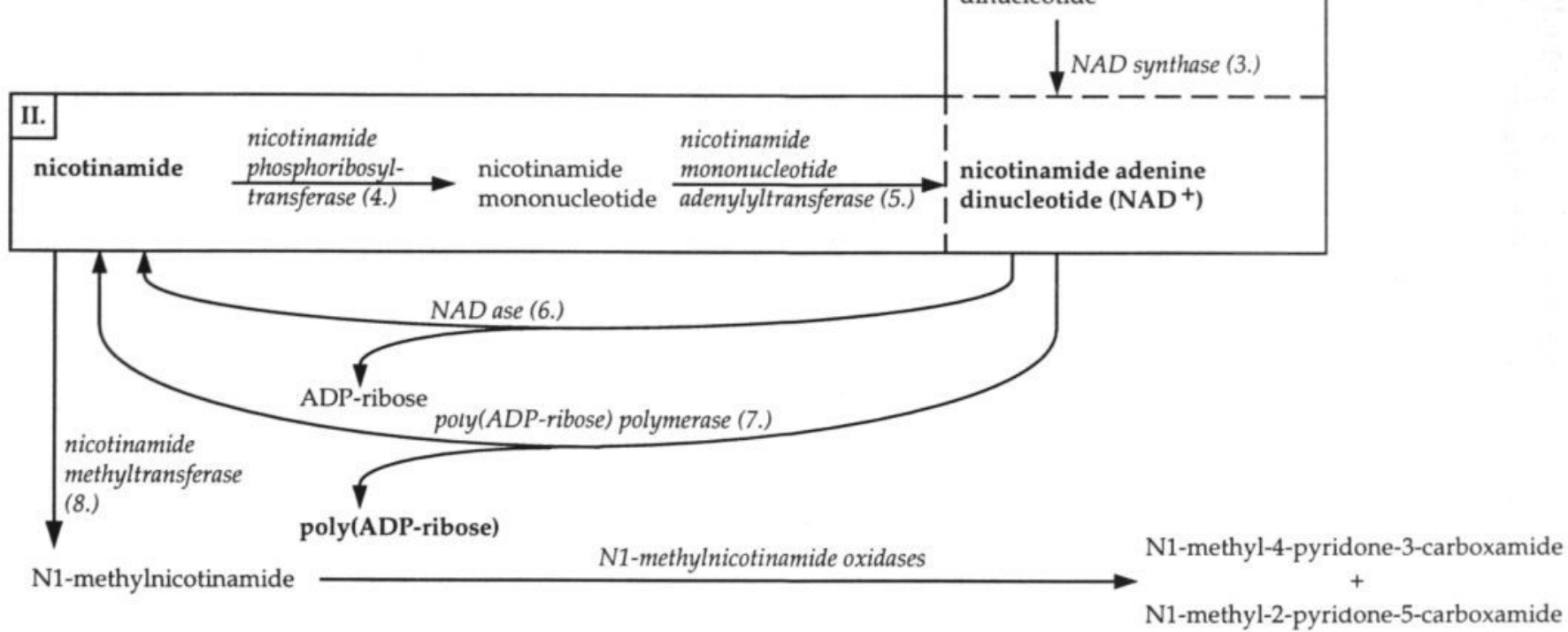

Figure 4.5. Major routes in niacin metabolism.

I. represents the Preiss-Handler Pathway. II. represents the Dietrich pathway.

(1.): EC 2.4.2.11; (2.): EC 2.7.1.23; (3.): EC 6.3.5.1; (4.): EC 2.4.2.12; (5.): EC 2.7.7.1; (6.): EC 3.2.2.5; (7.): EC 2.4.2.30; (8.): EC 2.1.1.1. 
NADase activity, plasma nicotinic acid may be converted into nicotinamide in the liver, as was proposed for mammals $(26,27)$. The present observation that increased nicotinic acid intake is associated with elevated blood nicotinamide levels (Table 4.2), is in agreement with the possible existence of such a metabolic pathway for nicotinic acid in humans in vivo (28). As a consequence, elevated plasma nicotinamide levels may be another cause of increased $\mathrm{NAD}^{+}$synthesis (or decreased $\mathrm{NAD}^{+}$catabolism, via poly(ADP-ribose) polymerase inhibition) in lymphocytes, via the Dietrich Pathway (Figure 4.5, pathway II.)(25). In fact, it has been proposed that nicotinamide at physiological concentrations is the main circulating precursor for $\mathrm{NAD}^{+}$in human red blood cells (29), Balb 3T3 cells (30) and human lymphocytes (25). In conclusion, $\mathrm{NAD}^{+}$may be synthesized in peripheral blood lymphocytes in humans either from directly absorbed nicotinic acid, or from nicotinamide after metabolism of nicotinic acid in other tissues.

Weitberg (10) reported a more evident increase in $\mathrm{NAD}^{+}$levels (from 4 pmol to $23 \mathrm{pmol} / 10^{6}$ cells) in lymphocytes obtained from two individuals, receiving $100 \mathrm{mg}$ nicotinic acid/day during 8 weeks, as compared to results from the present study. This is not likely to be explained by differences in experimental procedures, since in both studies similar methods were used for isolation of lymphocytes and for determination of $\mathrm{NAD}^{+}$(11). In the present study, lymphocytic $\mathrm{NAD}^{+}$levels as determined before intake, ranged from 31.1 to 107.9 pmol per $10^{6}$ cells. In other studies, comparable or higher cellular $\mathrm{NAD}^{+}$levels were reported for freshly isolated human lymphocytes (31), cultured resting human lymphocytes (25) and other cultured mammalian cells $(2,32-35)$. Lymphocytic $\mathrm{NAD}^{+}$levels, measured by Weitberg (10) prior to nicotinic acid supplementation, were much lower. Thus, it might be that in that study, lymphocytes were obtained from individuals with a relatively low niacin status, in whom a supplemention effect could be more easily established.

Concerning the effects of nicotinic acid supplementation on cytogenetic damage and ex vivo induced DNA repair, the present study shows that in the individuals receiving nicotinic acid, mean SCE frequencies tended to increase during supplementation, although this increase was within the range of SCE frequencies, found in the non-supplemented persons. Thus, it appears that the repair of SCE-causing DNA lesions might not be influenced by elevated lymphocytic $\mathrm{NAD}^{+}$levels, in contrast to $e x$ vivo oxygen-radical induced DNA strand breaks (10).

In the present study, at the individual level, increases of mean nicotinamide levels before and at the end of the supplementation period, as a consequence of elevated nicotinic acid intake, were positively correlated with increases of mean SCE frequencies before and at the end of the supplementation period, but this result was not statistically significant (Table 4.2). Moreover, blood nicotinamide levels appeared to be not significantly correlated with SCE frequencies both before and at the end of nicotinic acid intake. When the ratio of lymphocytic $\mathrm{NAD}^{+}$levels and blood nicotinamide levels decreases, it may be expected that 
poly(ADP-ribosylation) will be inhibited. However, no statistically significant correlation at the individual level was found between changes in this ratio and changes in SCE frequencies, during nicotinic acid supplementation. In addition, in lymphocytes obtained from 9 individuals, no effect of nicotinic acid supplementation was found on ( \pm )-anti-BPDE-induced poly(ADP-ribosylation) ex vivo (Figure 4.4). Thus, although nicotinamide has been shown to act as competitive inhibitor of poly(ADP-ribose) polymerase (31) and to induce SCEs in human lymphoblastoid cells and CHO cells in vitro $(36,37)$, we conclude that in humans in vivo, an elevation of blood nicotinamide levels, as a consequence of elevated nicotinic acid intake, does not appear to represent a causal factor in the observed increase of SCE frequencies. At present, it remains unknown what might have caused the relative elevation of SCE frequencies within the individuals, receiving additional nicotinic acid.

Little is known about the role of poly(ADP-ribosylation) in preventing mutagenesis. Conflicting results have been reported concerning the ex vivo action of poly(ADP-ribose) polymerase inhibitors in relation to carcinogeninduced mutations which depended on the carcinogenic agents used, the genetic loci used for mutant screening, as well as cellular progression at the time of carcinogen and poly(ADP-ribose) polymerase inhibitor treatment (38-40). When the hprt variant frequency data are considered, no clear positive or negative effect of nicotinic acid intake and of niacin status on mutagenesis has been demonstrated. Only within the dose group receiving $100 \mathrm{mg} /$ day, VF was significantly lower at the end of supplementation, but when all individuals receiving nicotinic acid were considered, VF tended to be even higher at the end of intake. Since considerable intra- and inter-individual variations in VF appeared to exist in these individuals, the biological relevance of these observations may be limited. Thus, it is concluded that prevention of mutagenesis by nicotinic acid supplementation in humans has not clearly been demonstrated. Furthermore, results from the present study indicate neither a preventive nor a potentiating effect of nicotinic acid intake on the presence of micronuclei, which is of relevance since micronuclei frequencies probably inversely relate to poly(ADP-ribosylation)-dependent repair of smoking-induced DNA strand breaks.

Age correlated positively with SCE frequencies, which might be an indication that, with increasing age, decreased repair capacity results in increased chromosomal damage. Previous studies also report positive associations between age and parameters of cytogenetic damage $(41,42)$, although no association has also been reported (43).

In conclusion, results from the present study show that supplementation of human male smokers with nicotinic acid in doses of 50-100 mg/day results in elevated blood nicotinamide levels, and to a minor degree, in increased lymphocytic $\mathrm{NAD}^{+}$levels. Sister chromatid exchange frequencies were elevated 
in individuals receiving nicotinic acid which however, could not be clearly attributed to alterations in niacin status or parameters of DNA repair, and which are therefore not likely related to modulation of poly(ADP-ribosylation)dependent repair of smoking related DNA damage.

Finally, it is concluded that this improved niacin status failed to increase $\mathrm{NAD}^{+}$-dependent poly(ADP-ribosylation)-mediated lymphocytic DNA repair, and consequently did not influence peripheral lymphocyte mutagenesis or chromosomal damage.

\section{Acknowledgements}

This study is supported by grant no. 28-2124 from the 'Praeventiefonds', The Hague, The Netherlands.

\section{References}

1. Lindahl, T. (1993) Instability and decay of the primary structure of DNA. Nature, 362, 709-715.

2. Lautier, D., Poirier, D., Boudreau, A., Alaoui-Jamali, M.A., Castonguay, A., Poirier, G. (1990) Stimulation of poly(ADP-ribose) synthesis by free radicals in C3H10T1/2 cells: relationship with $\mathrm{NAD}^{+}$metabolism and DNA breakage. Biochem. Cell. Biol., 68, 602-608.

3. Satoh, M.S., Lindahl, T. Role of poly(ADP-ribose) formation in DNA repair. Nature, 356, 356-358, 1992.

4. Schraufstatter, I.U., Hinshaw, D.B., Hyslop, P.A., Spragg, P.A., Cochrane, C.G. (1986) Oxidant injury of cells. DNA strand-breaks activate polyadenosine diphosphate-ribose polymerase and lead to depletion of nicotinamide adenine dinucleotide. J. Clin. Invest., 77, 1312-1320.

5. Althaus, F.R. (1992) Poly ADP-ribosylation: a histone shuttle mechanism in DNA excision repair. J. Cell. Sci., 102, 663-670.

6. Realini, C.A., Althaus, F.R. (1992) Histone shuttling by poly(ADP-ribosylation). J. Biol. Chem., 267, 18858-18865.

7. Molinete, M., Vermeulen, W., Bürkle, A., Menissier-de-Murcia, J., Kupper, J.H., Hoeijmakers, J.H., de-Murcia, G. (1993) Overproduction of the poly(ADP-ribose) polymerase DNA binding-domain blocks alkylation-induced DNA repair synthesis in mammalian cells. EMBO J., 12, 2109-2117.

8. Satoh, M.S., Poirier, G.G., Lindahl, T. (1993) NAD ${ }^{+}$-dependent repair of damaged DNA by human cell extracts. J. Biol. Chem., 268, 5480-5487.

9. Satoh, M.S., Lindahl, T. (1994) Enzymatic repair of oxidative DNA damage. Cancer Res., 54, 1899s-1901s.

10. Weitberg, A.B. (1989) Effect of nicotinic acid supplementation in vivo on oxygen radical-induced genetic damage in human lymphocytes. Mutat. Res., 216, 197-201.

11. Bernofsky, C., Swan, M. (1973) An improved cycling assay for nicotinamide adenine dinucleotide. Anal. Biochem., 53, 452-458.

12. Shibata, K., Kawada, T., Iwai, K. (1987) High performance liquid chromatographic determination of nicotinamide in rat tissue samples and blood after extraction with diethylether. J. Chromatogr., 422, 257-262.

13. Jacobson, M.K., Payne, D.M., Alvarez-Gonzalez, R., Juarez-Salinas, H., Sims, J.L., 
Jacobson, E.L. (1984) Determination of in vivo levels of polymeric and monomeric ADP-ribose by fluorescence methods. Methods Enzymol., 106, 483-494.

14. Stierum, R.H., van Herwijnen, M.H.M., Hageman, G.J. Kleinjans, J.C.S. (1994) Increased poly(ADP-ribose) polymerase activity during repair of ( \pm )-antibenzo[a]pyrene diolepoxide-induced DNA damage in human peripheral blood lymphocytes in vitro. Carcinogenesis, 15, 745-751.

15. Stierum, R.H., van Herwijnen, M.H.M, Maas, L.M., Hageman, G.J., Kleinjans, J.C.S. (1994) Measurement by ${ }^{32} \mathrm{P}$-postlabeling of ( \pm )-anti-benzo[a]pyrene-diolepoxide- $\mathrm{N}^{2}$. deoxyguanosine adduct persistence in unstimulated human peripheral blood lymphocytes. Mutat. Res., 325, 31-37.

16. Reddy, M.V., Gupta, R.C., Randerath, E., Randerath, K. (1984) ${ }^{32}$ P postlabeling test for covalent DNA binding of chemicals in vivo: application to a variety or aromatic carcinogens and methylating agents. Carcinogenesis, 5, 213-243.

17. Stierum, R.H., Hageman, G.J., Welle, I.J., Albering, H. Kleinjans, J. (1993) Evaluation of exposure reducing measures on parameters of genetic risk in a population occupationally exposed to coal fly ash. Mutat. Res., 319, 245-255.

18. Perry, P. and Wolff, S. (1974) New Giemsa method for the differential staining of sister chromatids. Nature, 25, 156-158.

19. Hageman, G., Welle, I., Stierum, R., Albering, H. and Kleinjans, J. (1993) Detection of 6-thioguanine-resistant human peripheral blood lymphocytes using 5-bromodeoxyuridine labeling in combination with immunocytochemical staining. Mutagenesis, 8, 495-501.

20. Fenech, M. Morley, A.A. (1985) Measurement of micronuclei in lymphocytes. Mutat. Res., 147, 29-36.

21. Jacobson, E.L. Jacobson, M.K. (1993) A biomarker for the assessment of niacin nutriture as a potential preventive factor in carcinogenesis. J. Intern. Med., 233, 59-62.

22. Zhang, J.Z., Henning, S.M. Swenseid, M.E. (1993) Poly(ADP-ribose) polymerase activity and DNA strand breaks are affected in tissues of niacin-deficient rats. J. Nutr., 123, 1349-1355.

23. Rawling, J.M., Jackson, T.M., Driscoll, E.R., Kirkland, J.B. (1994) Dietary niacin deficiency lowers tissue poly(ADP-ribose) and $\mathrm{NAD}^{+}$concentrations in Fischer-344 rats. J. Nutr., 124, 1597-1603.

24. Weiner, M., van Eys, J. (1983) Nicotinic acid nutrient-cofactor-drug.

25. Carson, D.A., Seto, S. Wasson, D.B. (1987) Pyridine nucleotide cycling and poly(ADP-ribose) synthesis in resting human lymphocytes. J. Immunol., 138, 1904-1907.

26. Henderson, L.M. (1983) Niacin. Annu. Rev. Nutr., 3, 289-307.

27. Shibata, K., Hayakawa, T., Taguchi, H., Iwai, K. (1991) Regulation of pyridine nucleotide coenzyme metabolism. Adv. Exp. Med. Biol., 294, 207-218.

28. Yuyama, S., Suzuki, T. (1991) The excretion of N1-methyl-2-pyridone-5carboxilic acid and related compounds in human subjects after oral administration of nicotinic acid, trigonalline and N1-methyl-2-pyridone-5-carboxilic acid. Adv. Exp. Med. Biol., 294, 475-479.

29. Micheli, V., Simmonds, H.A., Sestini, S., Ricci, C. (1990) Importance of nicotinamide as an NAD precursor in the human erythrocyte. Arch. Biochem. Biophys., 283, 40-45.

30. Jacobson, E.L., Lange, R.A., Jacobson, M.K. (1979) Pyridine nucleotide synthesis in 3T3 cells. J. Cell. Physiol., 99, 417-426.

31. Sims, J.L., Sikorsky, G.W., Catino, D.M., Berger, S.J., Berger, N.A. (1983) Poly(adenosinediphosphoribose) polymerase inhitors stimulate unscheduled deoxyribonucleic acid synthesis in normal human lymphocytes. Biochemistry, 21, 1813-1821. 
32. Juarez-Salinas, H., Sims, J.L., Jacobson, M.K. (1979) Poly(ADP-ribose) levels in carcinogen-treated cells. Nature, 282, 740-741.

33. Sims, J.L., Berger, S.J., Berger, N.A. (1983) Poly(ADP-ribose) polymerase inhibitors preserve nicotinamide adenine dinucleotide and adenosine 5'triphosphate pools in DNA-damaged cells: mechanism ofstimulation of unscheduled DNA synthesis. Biochemistry, 22, 5188-5194.

34. Jacobson, E.L., Antol, K.M., Juarez-Salinas, H., Jacobson, M.K. (1983) Poly(ADPribose) metabolism in ultraviolet irradiated human fibroblasts. J. Biol. Chem., 258, 103-107.

35. Rankin, P.W., Jacobson, E.L., Benjamin, R.C., Moss, J., Jacobson, M.K. (1989) Quantitative studies of inhibitors of ADP-ribosylation in vitro and in vivo. J. Biol. Chem., 264, 4312-4317.

36. Utakoji, T., Hosoda, K., Umezawa, K., Sawamura, M., Matsushima, T., Miwa, M., Sugimura, T. (1979) Induction of sister chromatid exchanges by nicotinamide in chinese hamster lung fibroblasts and human lymphoblastoid cells. Biochem. Biophys. Res. Commun., 90, 1147-1152.

37. Oikawa, A., Tohda, H., Kanai, M., Miwa, M., Sugimura, T. (1980) Inhibitors of poly(adenosine diphosphate ribose) polymerase induce sister chromatid exchanges. Biochem. Biophys. Res. Commun., 97, 1311-1316.

38. Cleaver, J.E., Morgan, W.F. (1991) Poly(ADP-ribose)polymerase: a perplexing participant in cellular responses to DNA breakage. Mutat. Res., 257, 1-18.

39. Bhattacharjee, S.B., Bhattacharyya, N. (1986) Influence of inhibitors of poly(ADP-ribose)polymerase activity on X-ray and ultraviolet light induced killing and mutation in Chinese hamster V79 cells. Carcinogenesis, 7, 1267-1271.

40. Gosh (Datta), R., Bhattacharjee, S.B. (1989) Influence of benzamide on killing and mutation of density-inhibited V79 cells by MNNG. Mutat. Res., 225, 137-141.

41. Lazutka, J.R., Dedonyte, V., Krapavickaite, D. (1994) Sister-chromatid exchanges and their distribution in human lymphocytes in relation to age, sex and smoking. Mutat. Res., 306, 173-180.

42. Fenech, M. (1993) The cytokinesis-block micronucleus technique and its application to genotoxicity studies in human populations. Environ. Health Perspect. Suppl., 101, 101107.

43. Di Giorgio, C.D., De Méo, M.P., Laget, M., Guiraud, H., Botta, A., Duménil, G. (1994) The micronucleus assay in human lymphocytes: screening for inter-individual variability and application to biomonitoring. Carcinogenesis, 15, 313-317. 


\section{Age-related negative associations between parameters of cytogenetic damage and ex vivo ( \pm )-anti-benzo[a]pyrene diolepoxide-induced unscheduled DNA synthesis in smoking humans}

R.H. Stierum, G.J. Hageman, M.H.M. van Herwijnen, M.S.E. van der Veer and J.C.S. Kleinjans

Department of Health Risk Analysis and Toxicology, University of Limburg, P.O. Box 616, 6200 MD Maastricht, The Netherlands

Accepted for publication in: Cancer Epidemiology, Biomarkers and Prevention

\section{Abstract}

Chemical or physical modification of DNA may cause an increase in genomic mutations or other genetic alterations, which may ultimately result in the onset of cancer. To avoid these deleterious effects of DNA damage, humans possess DNA repair mechanisms. Decreased DNA repair, induced ex vivo by ultraviolet light or ionizing radiation in human peripheral blood lymphocytes (PBLs), has been associated with aging. The aim of this study was to investigate whether repair of DNA damage, induced ex vivo in PBLs obtained from smokers $(n=20)$ by $( \pm)$-anti-benzo[a]pyrene diolepoxide $(( \pm)$-anti-BPDE), reactive metabolites from the environmental carcinogen benzo[a]pyrene, could also be associated with age. Further, age-related associations between ex vivo ( \pm )-anti-BPDEinduced DNA repair and the frequency of cytogenetic damage (sister chromatid exchange frequencies and micronuclei frequencies) in PBLs were evaluated. A statistically significant negative association was observed between ex vivo ( \pm )anti-BPDE-induced unscheduled DNA synthesis (UDS) and age of the donors. Also, parameters of lymphocytic DNA damage were negatively associated with ex vivo ( \pm )-anti-BPDE-induced UDS and positively associated with age in this population. It is concluded that with increasing age, the decrease of lymphocytic excision repair capacity may be responsible for increased lymphocytic DNA damage. Further, the phenomena observed here, may resemble processes in vivo that may result in age-related increased risk for cancer development in target organs of human smokers. 


\section{Introduction}

Humans are continuously exposed to various agents that may chemically or physically modify cellular DNA. It is believed that such modifications result in an time-dependent accumulation of genomic mutations or other genetic alterations $(1,2)$. If these alterations take place in proto-oncogenes or tumour suppressor genes, cell-cycle control may be lost, ultimately resulting in the onset of cancer. To protect cellular DNA from these deleterious effects of DNA damage, eukaryotic and prokaryotic cells, including human cells, possess DNA repair mechanisms. The importance of adequate DNA repair mechanisms in preventing carcinogenesis is exemplified by the DNA-repair defective autosomal recessive disease xeroderma pigmentosum. Cells obtained from individuals having this disease are deficient in nucleotide excision repair of large DNA adducts, for example ultraviolet light (UV)-induced cyclobutane pyrimidine dimers. Moreover, these individuals develop skin cancer even at early age and have a 2000 -fold increased risk of cancer compared with normal individuals (3).

Recently, decreased UV-induced DNA repair capacity of peripheral blood lymphocytes (PBLs) was associated with development of sunlight-induced skin cancer in the normal human population (4). Further, this decrease in DNA repair capacity was negatively associated with age. Other studies also report negative associations between the extent of DNA repair, induced by various DNA damaging agents ex vivo in PBLs, and age of the donor (5-7). Thus, it can be hypothesized that the ability to perform adequate DNA repair declines with increasing age. In turn, reduced repair capacity would result in increased persistence of DNA damage and increased cancer risk. At present, the potentially negative association between the capacity of DNA repair mechanisms and DNA damage in vivo has not yet been investigated in detail in carcinogen-exposed human populations. In a previous study (Chapter 4), the effects of in vivo nicotinic acid supplementation on niacin status, poly(ADP-ribosylation), cytogenetic damage and DNA repair in smoking humans were described. Aim of the present study was to investigate whether age-related associations exist between DNA repair and DNA damage in this carcinogen-exposed population of smokers. As parameter of DNA repair, ( \pm )-anti-benzo[a]pyrene diolepoxide $(( \pm)$ anti-BPDE)-induced unscheduled DNA (UDS) synthesis was determined $e x$ vivo in PBLs, obtained from these smokers. ( \pm -anti-BPDE, a mixture of benzo[a]pyrene metabolites, including the most reactive and mutagenic (+)-antienantiomer (8), induces a variety of DNA lesions that may activate base or nucleotide excision repair mechanisms (BER; NER) $(9,10)$. To estimate the extent of in vivo DNA damage, sister chromatid exchange frequencies (SCE) and micronuclei frequencies (MN) were determined in PBLs, after stimulation to proliferation ex vivo. 


\section{Materials and methods}

20 healthy male human smokers, smoking at least 10 cigarettes per day, were included into this study. Age of this population ranged from 21 to 55 years. Averaged $( \pm S D)$ number of cigarettes smoked per day, pack years, alcohol- and coffee consumption were $19.6 \pm 5.8$ cigarettes/day; $14.8 \pm 9.8$ pack years; $12.3 \pm 9.3$ glasses/week; $5.3 \pm 2.6$ cups/day, respectively. All volunteers agreed to participate to this study by giving their written informed consent. The study protocol was approved by the Medical Ethical Commission of the University of Limburg, Maastricht, The Netherlands.

Heparinized venous blood was collected from each donor at two different days, within a period of 8 weeks. The method of lymphocytic SCE and MN frequencies determination in whole blood cultures, in individuals from this population, has been described elsewhere (11 and Chapter 4). ( \pm )-anti-BPDEinduced UDS was determined in whole blood cultures. $( \pm)$-anti-BPDE $(( \pm)-7 \beta, 8 \alpha-$ dihydroxy-9 $\alpha, 10 \alpha$-epoxy-7,8,9,10-tetrahydrobenzo[a]pyrene, Midwest Research Institute, USA) stock solutions were prepared in anhydrous DMSO and stored at $-20{ }^{\circ} \mathrm{C}$ in the dark prior to one-off use. ( \pm )-anti-BPDE (or DMSO for solvent control-treated cultures) were added to a large volume of RPMI 1640 medium, supplemented with $10 \%$ foetal calf serum, $100 \mu \mathrm{g} / \mathrm{ml}$ streptomycin, $100 \mathrm{U} / \mathrm{ml}$ penicillin, $5 \mathrm{mM} \mathrm{L}$-glutamine and $50 \mathrm{U} / \mathrm{ml}$ heparin, of which $2.5 \mathrm{ml}$ were subsequently added to $0.2 \mathrm{ml}$ of blood, to a final concentration of $1.0 \mu \mathrm{M}$ (final concentration DMSO: 0.4\%). Medium and supplements were obtained from Gibco, Europe. Within 10 minutes after addition of the carcinogen, [methyl${ }^{3} \mathrm{H}$ ]thymidine (Amersham, sp. act. $\sim 80 \mathrm{Ci} / \mathrm{mmol}$ ) was added to a final concentration of $10 \mu \mathrm{Ci} / \mathrm{ml} .24 \mathrm{~h}$ after initiation of the cultures, cells were hypotonized in $75 \mathrm{mM}$ for 10-15 minutes and fixed with methanol : acetic acid (3 $: 1 ; \mathrm{v} / \mathrm{v})$. Part of the cell suspension was pipetted on slides. Autoradiography and determination of the number of net grains/nucleus were performed as described elsewhere (12), except that quantification was done with the aid of an Artek Counter $^{\mathrm{TM}}$ model 880 (New Brunswick Scientific, USA) (adjusted to count mode) in combination with a Sony CCD/RGB Videocamera (Sony, Japan), interfaced to a Zeiss Axioskop microscope. Results are presented as ( \pm )-anti-BPDE-induced UDS (in net grains/nucleus), after correction for the number of net grains, found in cells obtained from solvent control-treated cultures. Possible age-related correlations between ex vivo ( \pm )-anti-BPDE-induced UDS and parameters of cytogenetic damage were statistically analyzed by means of simple and multiple regression. 


\section{Results and discussion}

In Table 5.1, average and range of SCE, MN and ( \pm )-anti-BPDE-induced UDS, determined at two different days in peripheral blood lymphocytes obtained from male human smokers, are shown. In Figure 5.1, results of simple regression analysis between age of the donor and ( \pm )-anti-BPDE-induced UDS are shown. A significantly negative correlation was observed between age and ( \pm -anti-BPDEinduced-UDS (simple regression, $\mathrm{r}=-0.52, \mathrm{p}=0.019$ ). Based on the regression equation, average decrease in the extent of $( \pm)$-anti-BPDE-induced DNA repair was $1.1 \%$ per year between 20 and 60 years of age. Other studies also report negative associations between repair, induced ex vivo in PBLs with UV, and age (5-7). Pero and Östlund (5) and Lambert et al. (6) observed in a healthy population of non-smokers an average decrease in ex vivo UV-induced UDS of approximately $0.75 \%$ and $0.43 \%$ per year, respectively, between 20 and 60 years of age. Wei et al. (4) reported a reduction in removal of ex vivo UV-induced DNA damage of approximately $0.6 \%$ per year, within similar range of age. However, positive and no associations between DNA repair, determined as UV- or $\mathrm{N}$ acetoxy- $N$-acetylaminofluorene-induced UDS, and age have been reported as well $(5,13-15)$. This may be attributed to differences in duration of exposure of PBLs to carcinogens or in treatment of exposed cells with radiolabeled nucleotide precursors, thus in fact to differences in observed repair kinetics.

$( \pm)$-anti-BPDE treatment of mammalian cells ex vivo, including human PBLs, has been shown to result predominantly in formation of $\mathrm{N}^{2}$. deoxyguanosine adducts $\left(( \pm)\right.$-anti-BPDE- $\left.\mathrm{N}^{2}-\mathrm{dG}\right)(9,16-18)$. Repair of these $( \pm)$ anti-BPDE- ${ }^{2}$-dG adducts may proceed through transcription-coupled NER mechanisms $(9,10,19)$. Recently, a mechanism for transcription-coupled human NER has been proposed (20). It is assumed that at least 17 proteins are involved in damage recognition, local DNA unwinding, dual incision around the lesion, release of the damaged oligonucleotide and refilling of the excision gap. In addition, $( \pm)$-anti-BPDE treatment of isolated DNA has been shown to cause formation of base adducts like N7-guanine and its unstable imidazole ring open product (21), which may be substrates for base excision repair proteins in vivo. With increasing age, DNA repair may decline as a consequence of intracellular decrease in activity or levels of one or more of these proteins involved in NER or BER. In this study population, no significant association was observed between age of this population and the rate of $( \pm)$-anti-BPDE- $\mathrm{N}^{2}-\mathrm{dG}$ adduct removal, determined in isolated PBLs after ex vivo treatment with ( \pm )-antiBPDE (Chapter 4). Given the fact that UDS reflects the activity of all enzymes involved in excision repair, it may be that proteins which are involved in those steps of repair, following the initial recognition and removal of $( \pm)$-anti-BPDEinduced DNA damage, are affected by aging.

Associations between age and initial $( \pm)$-anti-BPDE- $\mathrm{N}^{2}-\mathrm{dG}$ adduct formation 
Table 5.1. Mean ( \pm standard deviation) and range of sister chromatid exchange frequencies, micronuclei frequencies and ( \pm )-anti-BPDE-induced unscheduled DNA synthesis determined in peripheral blood lymphocytes, obtained from male human smokers.

\begin{tabular}{lrr}
\hline parameter & mean $( \pm \mathrm{SD})$ & \multicolumn{1}{l}{ range } \\
\hline UDS (net grains/nucleus) & $23.1 \pm 6.2$ & $12.2-32.5$ \\
SCEs/cell & $6.1 \pm 1.0$ & $4.7-8.1$ \\
MN/1000 binucleated cells & $5.3 \pm 2.0$ & $2.5-9.5$ \\
\hline
\end{tabular}

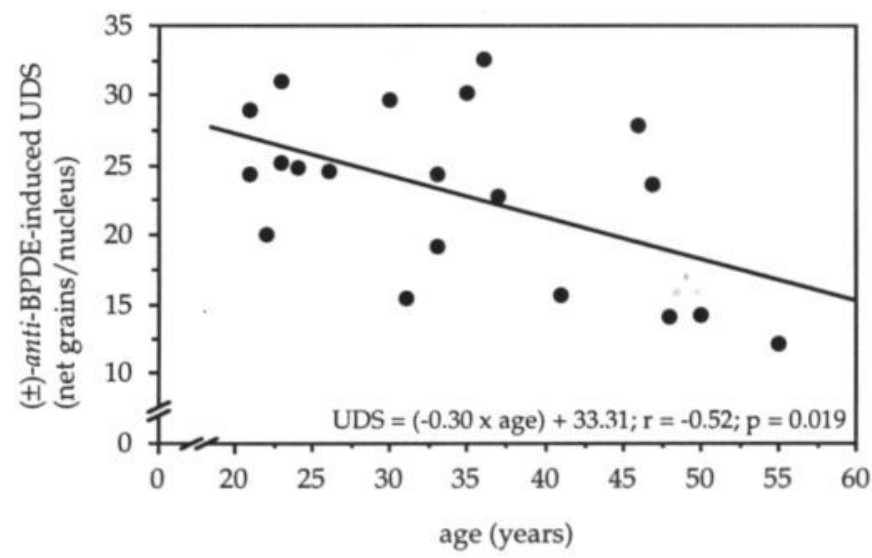

Figure 5.1. Correlation between ex vivo ( \pm )-anti-BPDE-induced UDS in peripheral blood lymphocytes obtained from male human smokers, and age of the donor.

(within 15 minutes after ex vivo exposure of PBLs to ( \pm )-anti-BPDE) have also not been observed in this population (Chapter 4). Thus, it can be excluded that the observed age-dependent decrease in UDS is related to decreased initial ( \pm )anti-BPDE-DNA adduct formation. Besides, since it is conceivable that aging results in decreased efficiency of detoxification mechanisms, rather an increase in initial ( \pm )-anti-BPDE-DNA binding with aging would have been expected.

With regard to possible effects of smoking on DNA repair, number of cigarettes smoked per day did not correlate significantly with ( \pm -anti-BPDE induced UDS. Pack years correlated positively with ( \pm )-anti-BPDE-induced UDS (simple regression: $\mathrm{r}=0.46 ; \mathrm{p}=0.042$ ). When the positive correlation between pack years and ( \pm )-anti-BPDE-induced UDS was adjusted for age, this significant correlation disappeared. Alcohol and coffee consumption were not significantly correlated with ( \pm )-anti-BPDE-induced UDS. Furthermore, the negative correlation between ( \pm )-anti-BPDE-induced UDS and age was not influenced by smoking habits (cigarettes/day). 


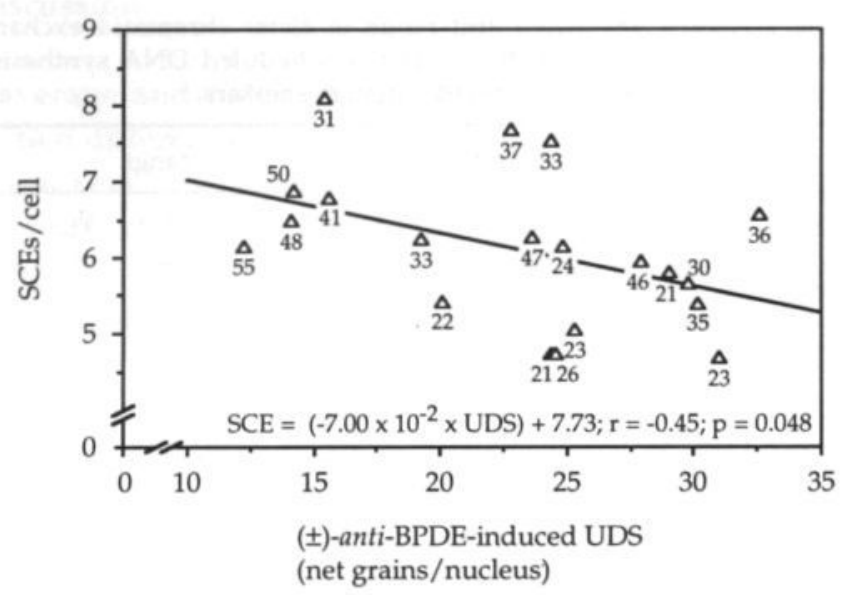

Figure 5.2. Correlation between SCE frequencies and ex vivo ( \pm -anti-BPDEinduced UDS in peripheral blood lymphocytes, obtained from male human smokers. Numbers represent the age of each individual donor.

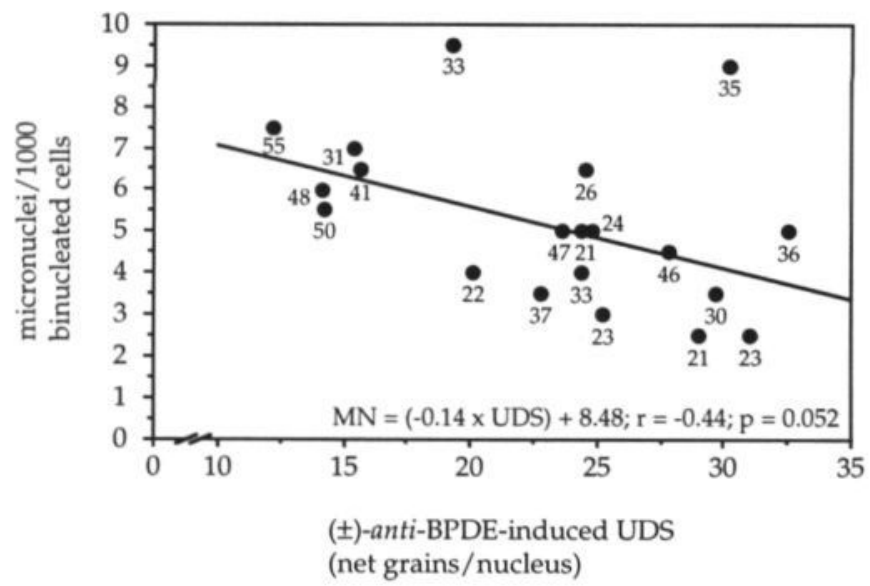

Figure 5.3. Correlation between $\mathrm{MN}$ frequencies and ex vivo ( \pm )-anti-BPDEinduced UDS in peripheral blood lymphocytes, obtained from male human smokers. Numbers represent the age of each individual donor.

Both SCE (simple regression: $\mathrm{r}=-0.45 ; \mathrm{p}=0.048$ ) and $\mathrm{MN}$ (simple regression: $\mathrm{r}=-$ $0.44 ; \mathrm{p}=0.052)$ negatively correlated with the extent of $( \pm)$-anti-BPDE-induced UDS (Figure 5.2 and Figure 5.3). After exclusion of two high MN values ( $\geq 9$ $\mathrm{MN} / 1000$ binucleated cells), the negative correlation between $\mathrm{MN}$ and ( \pm )-antiBPDE-induced UDS became highly significant $(\mathrm{p}<0.001)$. Smoking habits 
(cigarettes/day) did not influence these associations. Thus, the capacity of an individual's DNA repair, as determined ex vivo in ( \pm )-anti-BPDE-treated resting PBLs, is indicative for the capacity of those repair mechanisms in resting PBLs in vivo, which are responsible for removal of lesions that otherwise would have resulted in the induction of cytogenetic damage, in PHA-stimulated PBLs ex vivo.

In the same population, SCE frequencies were significantly positively correlated with age (simple regression: $\mathrm{r}=0.45, \mathrm{p}=0.044$; regression equation: $\mathrm{SCE}=$ $(0.041 *$ age $)+4.70) . \mathrm{MN}$ also correlated positively (non-significantly) with age (simple regression: $\mathrm{r}=0.39, \mathrm{p}=0.09$; regression equation: $\mathrm{MN}=(0.072 *$ age $)+2.81)$. After exclusion of the two highest MN values ( $\geq 9 \mathrm{MN} / 1000$ binucleated cells), this correlation reached statistical significance. Smoking habits (cigarettes/day) did not influence these associations. Previous studies also report positive associations between $\mathrm{SCE}$ or $\mathrm{MN}$, respectively, and age $(1,2)$, although no association has also been reported (22). Since ex vivo ( \pm )-anti-BPDE-induced UDS was negatively correlated with age (Figure 5.1), it is suggested that, with increasing age, a decrease in lymphocytic excision repair capacity is responsible for accumulation of (smoking-induced) DNA lesions in these cells. These lesions could have been responsible for the observed age-associated increase in cytogenetic damage. Adjustment for age resulted in disappearance of the significant correlation between SCE and $( \pm)$-anti-BPDE-induced UDS, suggesting again that the negative association between $( \pm)$-anti-BPDE-induced UDS and SCE is age-dependent.

In conclusion, age-related decrease in the capacity of an individual's DNA repair, determined ex vivo in ( \pm )-anti-BPDE-treated unstimulated PBLs, may resemble age-related decrease in the capacity of repair mechanisms in vivo. Consequently, those (smoking-induced) lesions that are responsible for the induction of SCE and MN in PBLs may accumulate with increasing age. PBLs do not represent themselves target organs for carcinogenic factors in vivo. However, in a recent study, increased peripheral blood lymphocytic chromosome aberrations were found to be associated with increased overall risk for cancer (23). Therefore, age-dependent decreased DNA repair and increased cytogenetic damage in PBLs may reflect similar processes that are involved in age-related development of cancer in target organs in human smokers.

\section{Acknowledgements}

This study is supported by grant no. 28-2124 from the 'Praeventiefonds', The Hague, The Netherlands.

\section{References}

1. Lazutka, J.R., Dedonyte, V., Krapavickaite, D. (1994) Sister-chromatid exchanges and their distribution in human lymphocytes in relation to age, sex and smoking. Mutat. 
Res., 306, 173-180.

2. Fenech, M. (1993) The cytokinesis-block micronucleus technique and its application to genotoxicity studies in human populations. Environ. Health Perspect. Suppl., 101, 101107.

3. Kraemer, K.H., Lee, M.M., Scotto, J. (1987) Xeroderma Pigmentosum. Cutaneous,ocular, and neurologic abnormalities in 830 published cases. Arch. Dermatol., 123, 241-250.

4. Wei, Q., Matanoski, G.M., Farmer, E.R., Hedayati, M.A., Grossman, L. (1993) DNA repair and aging in basal cell carcinoma: A molecular epidemiology study. Proc. Natl. Acad. Sci. U.S.A., 90, 1614-1618.

5. Pero, R.W., Östlund, C. (1980) Direct comparison, in human resting lymphocytes, of the inter-individual variations in unscheduled DNA synthesis induced by $\mathrm{N}$-acetoxy2-acetylaminofluorene and ultraviolet irradiation. Mutat. Res., 73, 349-361.

6. Lambert, B., Ringborg, U., Skoog, L. (1979) Age-related decrease of ultraviolet lightinduced DNA repair synthesis in human peripheral leukocytes. Cancer Res., 39, 27922795.

7. Singh, N.P., Danner, D.B., Tice, R.R., Brant, L., Schneider, E.L. (1990) DNA damage and repair with age in individual human lymphocytes. Mutat. Res., 237, 123-130.

8. Conney, A.H. (1982) Induction of microsomal enzymes by foreign chemicals and carcinogenesis by polycyclic aromatic hydrocarbons: G.H.A. Clowes memorial lecture. Cancer Res., 42, 4875-4917.

9. Yang, L.L., Maher, V.M., McCormick, J.J. (1980) Error-free excision of the cytotoxic, mutagenic $\mathrm{N}^{2}$-deoxyguanosine DNA adduct formed in human fibroblasts by $( \pm)$ $7 \beta, 8 \alpha$-dihydroxy-9 $\alpha, 10 \alpha$-epoxy-7,8,9,10-tetrahydrobenzo[a]pyrene. Proc. Natl. Acad. Sci. U.S.A., 77, 5933-5937.

10. Chen, R.-H., Maher, V.M., Brouwer, J., van de Putte, P., McCormick, J.J. (1992) Preferential repair and strand-specific repair of benzo[a]pyrene diol epoxide adducts in the HPRT gene of diploid human fibroblasts. Proc. Natl. Acad. Sci. U.S.A., 89, 5413-5417.

11. Stierum, R.H., Hageman, G.J., Welle, I.J., Albering, H.J., Schreurs, J.G.M., Kleinjans, J.C.S. (1993) Evaluation of exposure reducing measures on parameters of genetic risk in a population occupationally exposed to coal fly ash. Mutat. Res., 319, 245-255.

12. Stierum, R.H., van Herwijnen, M.H.M., Hageman, G.J., Kleinjans, J.C.S. (1994) Increased poly(ADP-ribose) polymerase activity during repair of ( \pm )-antibenzo[a]pyrene diolepoxide-induced DNA damage in human peripheral blood lymphocytes in vitro. Carcinogenesis, 15, 745-751.

13. Benigni, R., Calcagnile, A., Fabri, G., Giuliani, A., Leopardi, P., Paoletti, A. (1984) Biological monitoring of workers in the rubber industry. II. UV-induced unscheduled DNA synthesis in the lymphocytes of vulcanizers. Mutat. Res., 138, 105-111.

14. Madden, J.J., Falek, A., Shafer, D.A., Glick, J.H. (1979) Effects of opiates and demographic factors on DNA repair synthesis in human leukocytes. Proc. Natl. Acad. Sci. U.S.A., 76, 5769-5773.

15. Kovacs, E., Weber, W., Müller, Hj. (1984) Age-related variation in the DNArepair synthesis after UV-C irradiation in unstimulated lymphocytes of healthy blood donors. Mutat. Res., 131, 231-237.

16. Jeffrey, A.M., Jenette, K.W., Blobstein, S.H., Weinstein, I.B., Beland, F.A., Harvey, R.G., Kasai, H., Miura, I., Nakanishi, K. (1976) Benzo[a]pyrene-nucleic acid derivative found in vivo: structure of a benzo[a]pyrenetetrahydrodiol epoxideguanosine adduct. J. Am. Chem. Soc., 98, 5714-5715.

17. Celotti, L., Ferraro, P., Furlan, D., Zanesi, N., Pavanello, S. (1993) DNA repair in human lymphocytes treated in vitro with $( \pm)$-anti- and $( \pm)$-syn-benzo[a]pyrene diolepoxide. Mutat. Res., 294, 117-126. 
18. Stierum, R.H., van Herwijnen, M.H.M., Maas, L.M., Hageman, G.J., Kleinjans, J.C.S. (1994) Measurement by 32P-postlabeling of $( \pm$ )-anti-benzo[a]pyrenediolepoxide- $\mathrm{N}^{2}$-deoxyguanosine adduct persistence in unstimulated human peripheral blood lymphocytes. Mutat. Res., 325, 31-37.

19. Maher, V.M., McCormick, J.J. (1983) Relationship between excision repair and the cytotoxic and mutagenic action of chemicals and UV radiation. Basic Life Sci., 23, 271-290.

20. Sancar, A. (1994) Mechanisms of DNA excision repair. Science, 266, 1954-1956.

21. Osborne, M.R., Jacobs, S., Harvey, R.G., Brookes, P. (1981) Minor products from the reaction of $(+)$ and (-) benzo[a]pyrene-anti-diolepoxide with DNA. Carcinogenesis, 2, 553-558.

22. Di Giorgio, C.D., De Méo, M.P., Laget, M., Guiraud, H., Botta, A., Duménil, G. (1994) The micronucleus assay in human lymphocytes: screening for inter-individual variability and application to biomonitoring. Carcinogenesis, 15, 313-317.

23. Hagmar, L., Brogger, A., Hansteen, I.L., Heim, S., Hogstedt, B., Knudsen, L., Lambert, B., Linnainmaa, K., Mitelman, F., Nordenson, I., et al. (1994) Cancer risk in humans predicted by increased levels of chromosomal aberrrations in lymphocytes: Nordic study group on the health risk of chromosome damage. Cancer Res., 54, 29192922. 


\section{$( \pm)$-anti-benzo[a]pyrene diolepoxide-induced adaptive response in human peripheral blood lymphocytes is not associated with enhanced induction of poly(ADP- ribosylation)}

R.H. Stierum, I.J. Welle, M.H.M. van Herwijnen, I.H. Zwingmann, L.M. Maas, G.J. Hageman and J.C.S. Kleinjans

Department of Health Risk Analysis and Toxicology, University of Limburg, P.O. Box 616, 6200 MD Maastricht, The Netherlands

Based on a manuscript submitted to: Mutation Research

\section{Abstract}

The adaptive response in human peripheral blood lymphocytes (PBLs) can be characterized as the reducing effect of pre-exposure to low levels of ionizing radiation or genotoxic chemicals on the extent of chromosomal damage, induced by exposure to high levels of these agents. It has been postulated that the DNA repair related enzyme poly(ADP-ribose) polymerase is necessary for the induction of an adaptive response in PBLs. The aim of the present study was to investigate whether ( \pm )-7 $\beta, 8 \alpha$-dihydroxy- $9 \alpha, 10 \alpha$-epoxy-7,8,9,10-tetrahydrobenzo[a]pyrene $(( \pm)$-anti-BPDE), from which the $(+)$-enantiomer represents the ultimate carcinogenic form of the environmental pollutant benzo[a]pyrene, induces an adaptive response in PBLs. Moreover, the possible involvement of poly(ADP-ribosylation) and DNA repair synthesis in the ( \pm )-anti-BPDE-induced adaptive response was assessed. In PBLs obtained from 4 out of 10 healthy male humans, pre-exposure to $2.5 \mathrm{nM}( \pm)$-anti-BPDE resulted in reduced micronuclei formation, as marker for chromosomal damage, induced by $2.5 \mu \mathrm{M}( \pm)$-antiBPDE. The degree of adaptation was found to depend on the concentration of $( \pm)$ anti-BPDE applied during pre-exposure and varied between as well as within individuals. No associations were however found between the adaptive response, determined as decrease in micronuclei formation, and the effects of pre-exposure on challenge-induced poly(ADP-ribosylation) or unscheduled DNA synthesis. 


\section{Introduction}

The adaptive response (AR), first described by Samson and Cairns (1) for MNNGinduced DNA mutations in E. coli, has originally been defined as the preventive effect of pre-exposure to low levels of an alkylating agent on formation of mutations and decrease in cell survival, caused by exposure to a high level of the alkylating agent at later time.

Olivieri et al. (2) showed that a comparable phenomenon existed in human peripheral blood lymphocytes (PBLs). They observed a reduction in the number of chromosome aberrations when PBLs were pre-treated with low levels of radioactive thymidine which was followed by a challenge of X-rays, in comparison to the number of chromosome aberrations induced by X-ray exposure alone.

Subsequently, the existence of an inducible AR in human PBLs for X-ray induced cytogenetic damage has been confirmed by others, measuring various cytogenetic end-points, and using as pre-conditioning agents X-radiation (3-9), bleomycin $(10,11)$, hydrogen peroxide $(12,13)$, radioisotopes $(5,14)$ and hyperthermia (15).

Further, AR-like phenomena in human PBLs have also been observed with respect to damage induced by challenge treatments with other agents than $\mathrm{X}$-rays, such as radon (16), mitomycin C (17-19), bleomycin (11,19), MNNG (20) and tritiated thymidine (19).

The mechanism underlying the adaptation in PBLs to ionizing radiation and other agents, is little understood. Cycloheximide, a protein synthesis inhibitor, has been found to inhibit the AR to ionizing radiation $(15,21)$, suggesting that synthesis of certain proteins is necessary for induction of an AR. Olivieri et al. (2) proposed that AR involves the induction of a chromosomal repair mechanism. Indeed, the DNA repair-related nicotinamide adenine dinucleotide $\left(\mathrm{NAD}^{+}\right)$dependent enzyme poly(ADP-ribose) polymerase might be involved in AR, since 3 -aminobenzamide, an inhibitor of this enzyme $(22,23)$, has been found to inhibit the $\left[{ }^{3} \mathrm{H}\right]$ thymidine-, X-ray- and bleomycin-induced AR for X-rays in PBLs $(6,10,14,24)$. In addition, the $\left[{ }^{3} \mathrm{H}\right]$-thymidine-induced AR for $\mathrm{X}$-rays did not occur when PBLs were grown in absence of nicotinamide (24), one of the precursors of $\mathrm{NAD}^{+}$in PBLs (25).

In a previous study, we showed that in isolated human PBLs, poly(ADPribosylation) increased and intracellular $\mathrm{NAD}^{+}$-levels decreased during repair of DNA damage caused by exposure to high levels of ( \pm )-anti-benzo[a]pyrene diolepoxide (( \pm )-anti-BPDE) (26). Given the possible involvement of poly(ADPribose) polymerase in the AR in human PBLs induced by ionizing radiation and radio-mimetic agents, it became of interest to assess whether pre-exposure of PBLs to low doses of ( \pm )-anti-BPDE could also induce a similar protection against cytogenetic damage induced by higher doses of ( \pm )-anti-BPDE. 
Domínguez et al., (13) showed that the cytokinesis-block micronucleus method of Fenech and Morley (27) can be applied to detect the AR to ionizing irradiation in human PBLs. Within this context, the purpose of this study was to evaluate whether pre-exposure of isolated human peripheral blood lymphocytes, obtained from 10 non-exposed individuals, to low doses of ( \pm )-anti-BPDE prevents the formation of micronuclei (MN), as marker of chromosomal loss or fragmentation, caused by exposure to higher doses of $( \pm)$-anti-BPDE. To determine if a preventive effect of pre-exposure on the extent of MN formation was related to DNA repair capacity, unscheduled DNA synthesis (UDS) was determined after $( \pm)$-anti-BPDE-challenge. In order to assess the possible role of poly(ADP-ribose) polymerase in an AR, poly(ADP-ribose) formation, as well as decrease in lymphocytic $\mathrm{NAD}^{+}$levels were determined after high $( \pm)$-anti-BPDE exposure. In PBLs, obtained from a limited number of individuals, $( \pm$ )-antiBPDE- $\mathrm{N}^{2}$-deoxyguanosine $\left(( \pm)\right.$-anti-BPDE- $\left.\mathrm{N}^{2}-\mathrm{dG}\right)$ adduct levels were measured in order to assess whether pre-exposure reduces initial ( \pm )-anti-BPDE-DNA binding.

\section{Materials and methods}

\section{Subjects}

10 healthy non-smoking male humans who were not occupationally exposed to genotoxic agents, were included into this study. All persons officially agreed to participate by giving their written informed consent. The study protocol was approved by the Medical Ethical Commission of the University of Limburg. Averaged $( \pm \mathrm{SD})$ age, alcohol and coffee consumption were $24.6 \pm 3.2$ years; $4.1 \pm$ 2.9 glasses/week; $2.7 \pm 2.1$ cups/day, respectively.

\section{Isolation of peripheral blood lymphocytes and cell culture}

Heparinized venous blood samples were collected and diluted by an equal volume of RPMI 1640 medium, prior to isolation of PBLs on Lymphoprep ${ }^{\mathrm{TM}}$ (Nycomed, Norway). After centrifugation for $15 \mathrm{~min}$ at $800 \mathrm{~g}$, interfaces were collected and washed twice with RPMI 1640 medium. Mononuclear cells were counted and cell suspensions were adjusted to a density of 1-2 × $10^{6}$ cells $/ \mathrm{ml}$ RPMI 1640 medium which was supplemented with $15 \%(\mathrm{v} / \mathrm{v})$ fetal calf serum, Lglutamine, $100 \mathrm{U} / \mathrm{ml}$ penicillin, $100 \mu \mathrm{g} / \mathrm{ml}$ streptomycin. For the determination of $\mathrm{MN}$ frequencies, UDS, NAD+-levels, poly(ADP-ribose) polymer formation and relative $( \pm)$-anti-BPDE- $\mathrm{N}^{2}-\mathrm{dG}$ adduct levels, cultures contained respectively at least $3 \times 10^{6}, 1 \times 10^{6}, 3 \times 10^{6}, 35 \times 10^{6}$ and $15 \times 10^{6}$ cells.

Cells were grown in presence of $40 \mu \mathrm{l}$ (approximately $52 \mu \mathrm{g}$ ) phytohemagglutinin (PHA)/ml medium in culture flasks and tubes in a humidified incubator at $37{ }^{\circ} \mathrm{C}$ under $5 \% \mathrm{CO}_{2}$. All cell culture media and supplements were obtained from Gibco, Europe. 


\section{Treatment of cells with ( \pm )-anti-BPDE}

$( \pm)$-anti-BPDE (Midwest Research Institute, USA) stock solutions were prepared in anhydrous dimethylsulfoxide (DMSO) and stored at $-20^{\circ} \mathrm{C}$ in the dark prior to use. $24 \mathrm{~h}$ after initiation of the cultures, cells were given a priming dose of $( \pm)$ anti-BPDE, by adding stock solution by micropipette to the desired final concentrations. PBLs were cultured for another $24 \mathrm{~h}$ and subsequently given a challenge dose of $( \pm)$-anti-BPDE $(t=48 \mathrm{~h})$, again by adding stock solution. PBLs used for determination of poly(ADP-ribose) polymer formation were challenged by $40.0 \mu \mathrm{M}( \pm)$-anti-BPDE. It cannot be excluded that this incubation concentration may be cytotoxic to a certain degree, but we have shown in a previous study (26) that concentrations of ( \pm )-anti-BPDE in the order of 10-100 $\mu \mathrm{M}$ are required in order to detect carcinogen-induced poly(ADP-ribose) polymer formation.

Adhering cells from cultures used for determination of relative $( \pm)$-antiBPDE-N ${ }^{2}-d G$ adduct levels and poly(ADP-ribose) polymer formation were gently scraped off the culture flask, already before $( \pm)$-anti-BPDE challenge. This enabled the processing of treated cultures for determination of poly(ADP-ribose) polymer formation and $( \pm)$-anti-BPDE- $\mathrm{N}^{2}-\mathrm{dG}$ adduct levels as rapid as possible.

\section{Determination of micronuclei frequencies}

For determination of MN, cells were cultured in duplicate and cytochalasin B (cyt B) (Sigma, Axel, The Netherlands) was added to a final concentration of $6 \mu \mathrm{g} / \mathrm{ml}$, immediately after addition of the challenge dose. Cells were cultured for another $20 \mathrm{~h}$ prior to harvesting. In some experiments, cells were allowed to recover for both $20 \mathrm{~h}$ and $30 \mathrm{~h}$ in presence of cyt B, prior to harvesting, in order to evaluate whether the expression of an AR is influenced by asynchronicity of cellpopulations.

At the respective time points at the end of the culturing period, cultures were hypotonized for $10 \mathrm{~min}$ in $75 \mathrm{mM} \mathrm{KCl}$ and fixed with methanol : acetic acid $(3: 1$, v/v). Slides were prepared and stained for 20-30 min with 3\% Giemsa. Prior to microscopic analysis, slides were encoded and for each variable, at least 1000 binucleated cells were analyzed for the presence of MN. No distinction was made between binucleated cells with one or more than one $\mathrm{MN}$ : multinucleated cells were scored as one binucleated cell with one MN. The expected number of MN for combined treatment was calculated according to the following formula: [number of $\mathrm{MN}$ (expected)] = [number of $\mathrm{MN}$ primer treatment] + [number of $\mathrm{MN}$ challenge] - [number of $\mathrm{MN}$ solvent control].

Results were considered as indicative for a preventive effect when the observed number of $\mathrm{MN}$ was lower than the expected number.

\section{Determination of unscheduled DNA synthesis}

For determination of UDS (from duplicate cultures), within $15 \mathrm{~min}$ after 
addition of the challenge dose of $( \pm)$-anti-BPDE, $\left[\right.$ methyl- $\left.{ }^{3} \mathrm{H}\right]$ thymidine (Amersham, England, sp. act. $83 \mathrm{Ci} / \mathrm{mmol}$ ) was added to a final concentration of $10 \mu \mathrm{Ci} / \mathrm{ml}$. Cells were cultured for another $24 \mathrm{~h}$, prior to harvesting as described above. The degree of UDS was determined as described previously (26). Processing of all slides was done with the same batch of Ilford K2 Scientific Emulsion. Expected number of net grains/nucleus was calculated similarly as described under 'Determination of micronuclei frequencies'. Results were considered to indicate a protective mechanism when the observed UDS was higher than the expected UDS.

\section{$\mathrm{NAD}+$ determination}

For determination of lymphocytic $\mathrm{NAD}^{+}$levels (in duplicate), $55 \mathrm{~min}$ after challenge, cultures were centrifuged for $10 \mathrm{~min}$ at $400 \mathrm{~g}$. Extraction of pyridine nucleotides and determination of $\mathrm{NAD}^{+}$-levels were performed as described elsewhere (26).

The expected decrease in $\mathrm{NAD}^{+}$-levels was calculated according to the following formula:

[expected decrease in $\mathrm{NAD}^{+}$-levels] =

$\left[\mathrm{NAD}^{+}\right.$-levels solvent control - $\mathrm{NAD}^{+}$-levels primer treatment] $+\left[\mathrm{NAD}^{+}\right.$-levels solvent control - $\mathrm{NAD}^{+}$-levels challenge].

When the observed decrease in $\mathrm{NAD}^{+}$-levels was higher than the expected decrease, this was considered to represent a potentiation of pre-exposure on challenge-induced lowering of $\mathrm{NAD}^{+}$-levels, and thus probably on poly(ADPribosylation).

\section{Determination of poly(ADP-ribose) polymer formation}

At 15 and $35 \mathrm{~min}$ after challenge, aliquots of the cell suspension were transferred to $50 \mathrm{ml}$ culture tubes on ice and the material was precipitated for at least $30 \mathrm{~min}$ in $20 \%$ TCA. The amount of ethenoribosyladenosine ( $\varepsilon$ Rado), which is the characteristic nucleoside derived from poly(ADP-ribose) polymers, was determined according to the procedure of Jacobson (28) with minor modifications as described previously (26).

Because it was necessary to withdraw already at least $200 \mathrm{ml}$ of blood from each donor to perform singular experiments, it was impossible to culture cells in duplicate for each variable. However, intra-assay variation, as judged from triplicate determinations of $\varepsilon$ Rado from purified [adenine- ${ }^{14} \mathrm{C}$ ]poly(ADP-ribose), using the same batches of purified [adenine- $\left.{ }^{14} \mathrm{C}\right]$ poly(ADP-ribose), DHB-Biorex, enzymes and chemicals as used for all samples in these experiments, was $\sim 3 \%$. Expected amounts of $\varepsilon$ Rado, and thus the extent of poly(ADP-ribose) polymer formation, were calculated according to the following formula:

[amount of $\varepsilon$ Rado (expected)] = [amount of $\varepsilon$ Rado primer treatment] + [amount of $\varepsilon$ Rado challenge] - [amount of $\varepsilon$ Rado solvent control]. 


\section{Determination of relative ( \pm )-anti-BPDE- $N^{2}-d G$ adduct levels}

$15 \mathrm{~min}$ after challenge, duplicate cell cultures were transferred to $50 \mathrm{ml}$ culture tubes on ice and centrifuged for $10 \mathrm{~min}$ at $400 \mathrm{~g}$. Extraction and digestion of DNA was performed as described elsewhere (29) and $\left( \pm\right.$-anti-BPDE- $\mathrm{N}^{2}-\mathrm{dG}$ adduct levels were determined using standard adduct labeling, according to the procedure of Reddy et al. (30). Chromatograms were visualized and quantified using a Molecular Dynamics Phosphor Imager with Image Quant ${ }^{\mathrm{TM}}$ software. All enzymes were from Boehringer Mannheim, Almere, The Netherlands.

\section{Statistical analysis}

To determine whether a protective effect of pre-exposure on $\mathrm{MN}$ formation could be associated with induction of repair mechanisms, Spearman Rank Correlation analysis was performed between all parameters, with calculated differences between expected and observed values.

\section{Results}

In Figure 6.1, the induction of $\mathrm{MN}$ in isolated PHA-stimulated peripheral blood lymphocytes obtained from two donors is shown after challenge with ( \pm )-antiBPDE. A dose dependent induction of $\mathrm{MN}$ was observed in which the number of $\mathrm{MN}$ reached a maximum at $( \pm)$-anti-BPDE concentrations higher than $1.0 \mu \mathrm{M}$. Also, at least for this experiment, the number of $\mathrm{MN}$ increased when cells were held in presence of cyt B for $30 \mathrm{~h}$, as compared to $20 \mathrm{~h}$ of cyt B incubation (not shown). In our previous study (26), induction of UDS and decrease in NAD+levels were observed when in PBLs were exposed to ( \pm )-anti-BPDE in a similar concentration range. Therefore, a challenge concentration of $2.5 \mu \mathrm{M}$ was applied in subsequent experiments (except for determination of poly(ADP-ribose) polymer formation as explained in the Methods section).

Figure 6.2 shows the effect of $24 \mathrm{~h}( \pm)$-anti-BPDE-pre-exposure on ( \pm )-antiBPDE challenge-induced MN in PBLs, obtained from the same two donors. Cells were allowed to recover for $20 \mathrm{~h}$ in presence of cyt $\mathrm{B}$. Results are expressed as the difference between expected and observed number of MN. For both donors, when cells were pre-treated with 2.5 or $5.0 \mathrm{nM}( \pm)$-anti-BPDE, differences between expected and observed number of $\mathrm{MN}$ for combined treatment were greater than zero. These findings are indicative for a preventive effect of $( \pm)$ anti-BPDE pre-exposure on challenge-induced MN. When a higher preexposure concentration ( \pm )-anti-BPDE was chosen, the preventive effect was no longer present for donor 1, but still occurred for donor 2. Based on the observation that the preventive effect of pre-exposure was highest, when cells were treated with $2.5 \mathrm{nM}( \pm)$-anti-BPDE, this concentration was chosen in subsequent experiments. 


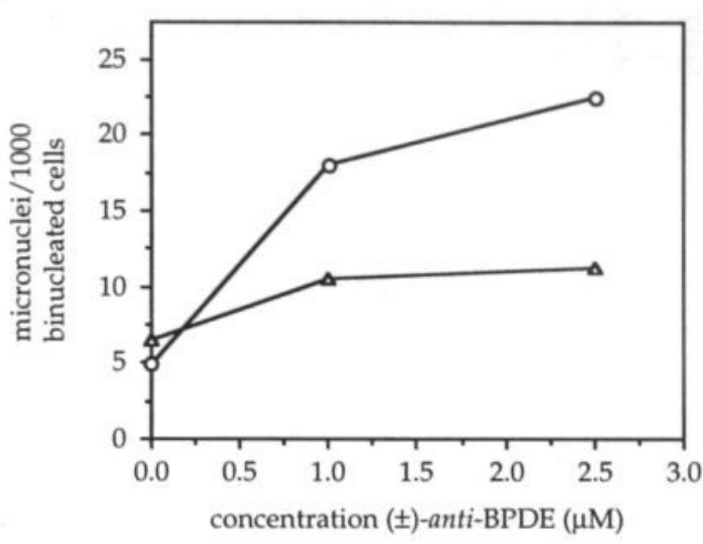

Figure 6.1. Induction of micronuclei in isolated PHA-stimulated peripheral blood lymphocytes, obtained from two donors, after challenge with ( \pm )-anti-BPDE, $48 \mathrm{~h}$ after inititation of cultures. PBLs were allowed to recover for $20 \mathrm{~h}$ in presence of cytochalasin B. Donor 1: $(\Delta)$; donor 2: (O).

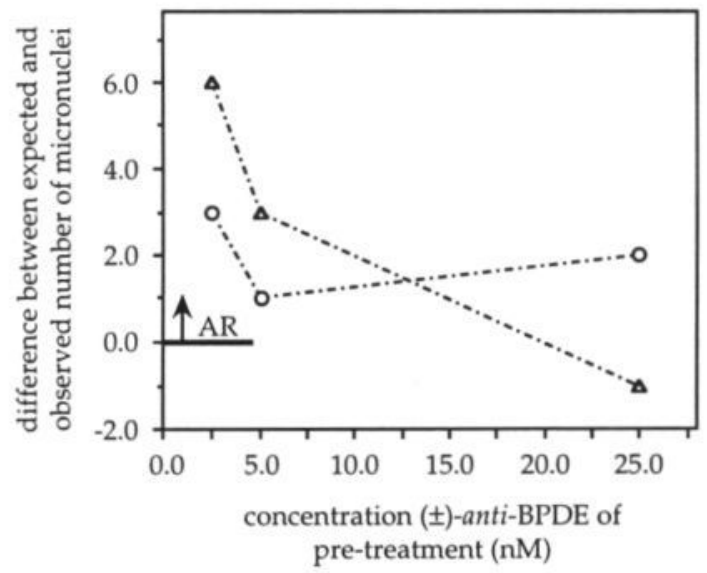

Figure 6.2. Effect of pre-exposure with low concentrations of ( \pm )-anti-BPDE on induction of micronuclei in peripheral blood lymphocytes with $2.5 \mu \mathrm{M}( \pm)$-antiBPDE. Donor 1: $(\Delta)$; donor 2: $(\mathrm{O})$. PBLs were allowed to recover for $20 \mathrm{~h}$ in presence of cytochalasin B. When the difference between the expected and observed number of micronuclei is greater than zero, pre-exposure induces an adaptive response (AR). 
Table 6.1. Effect of ( \pm )-anti-benzo[a]pyrene diolepoxide exposure on induction of micronuclei, induction of unscheduled DNA synthesis and NAD ${ }^{+}$

levels, in isolated peripheral blood lymphocytes, with or without pre-exposure to $2.5 \mathrm{nM}( \pm)$-anti-benzo[a]pyrene diolepoxide. Mean values are shown, obtained from duplicate cultures.

\begin{tabular}{|c|c|c|c|c|c|c|c|c|c|c|c|c|c|c|}
\hline \multirow[t]{2}{*}{ donor } & \multirow{2}{*}{$\begin{array}{l}( \pm) \text {-anti- } \\
\text { BPDE } \\
(\mu \mathrm{M}) \\
t=24 h: \\
t=48 h:\end{array}$} & \multicolumn{4}{|c|}{$\begin{array}{l}\text { MN/ } \\
1000 \text { binucleated cells* }\end{array}$} & \multicolumn{4}{|c|}{$\begin{array}{l}\text { UDS } \\
\text { (net grains/nucleus) }\end{array}$} & \multicolumn{5}{|c|}{$\begin{array}{l}\mathrm{NAD}^{+} \\
\text {(pmol } / 1 \times 10^{6} \text { cells) }\end{array}$} \\
\hline & & $\begin{array}{l}0.0 \\
0.0\end{array}$ & $\begin{array}{l}2.5 \times 10^{-3} \\
0.0\end{array}$ & $\begin{array}{l}0.0 \\
2.5\end{array}$ & $\begin{array}{l}2.5 \times 10^{-3} \\
2.5 \\
\text { (expected) }\end{array}$ & $\begin{array}{l}0.0 \\
0.0\end{array}$ & $\begin{array}{l}2.5 \times 10^{-3} \\
0.0\end{array}$ & $\begin{array}{l}0.0 \\
2.5\end{array}$ & $\begin{array}{l}2.5 \times 10^{-3} \\
2.5 \\
\text { (expected) }\end{array}$ & $\begin{array}{l}0.0 \\
0.0\end{array}$ & $\begin{array}{l}2.5 \times 10^{-3} \\
0.0\end{array}$ & $\begin{array}{l}0.0 \\
2.5\end{array}$ & $\begin{array}{l}2.5 \times 10^{-3} \\
2.5\end{array}$ & $\begin{array}{l}\mathrm{NAD}^{+} \downarrow \downarrow \\
\text { observed } \\
\text { (expected) }\end{array}$ \\
\hline $2 *$ & & 5 & 4 & 4 & $\begin{array}{r}7 \\
(3)\end{array}$ & 1.8 & 1.6 & 6.1 & $\begin{array}{r}6.3 \\
(5.9)\end{array}$ & 171.9 & 124.5 & 118.8 & 151.4 & $\begin{array}{r}20.5 \\
(100.5)\end{array}$ \\
\hline 3 & & 4 & 4 & 10 & $\begin{array}{r}8 \\
(10)\end{array}$ & 1.0 & 1.3 & 4.1 & $\begin{array}{r}4.6 \\
(4.4)\end{array}$ & 139.3 & 183.9 & 139.0 & 133.9 & $\begin{array}{r}5.4 \\
(-44.3)\end{array}$ \\
\hline 4 & & 4 & 2 & 8 & $\begin{array}{r}8 \\
(6)\end{array}$ & 1.8 & 1.6 & 3.3 & $\begin{array}{r}6.1 \\
(3.1)\end{array}$ & 170.5 & 211.1 & 130.1 & 173.5 & $\begin{array}{r}-3.0 \\
(-0.2)\end{array}$ \\
\hline 7 & & 9 & 6 & 72 & $\begin{array}{r}56 \\
(69)\end{array}$ & 0.9 & 0.5 & 4.4 & $\begin{array}{r}6.9 \\
(4.0)\end{array}$ & 111.8 & 98.4 & 136.4 & 119.1 & $\begin{array}{r}-7.3 \\
(-11.2)\end{array}$ \\
\hline 8 & & 21 & 16 & 45 & $\begin{array}{r}40 \\
(40)\end{array}$ & 1.9 & 0.8 & 4.9 & $\begin{array}{r}6.8 \\
(3.8)\end{array}$ & 131.4 & 117.1 & 117.7 & 182.4 & $\begin{array}{l}-51.0 \\
(28.0)\end{array}$ \\
\hline 9 & & 10 & 9 & 24 & $\begin{array}{r}32 \\
(23)\end{array}$ & 1.2 & 0.9 & 4.8 & $\begin{array}{r}4.4 \\
(4.5)\end{array}$ & 97.9 & 79.0 & 62.7 & 81.5 & $\begin{array}{r}16.4 \\
(54.1)\end{array}$ \\
\hline 10 & & 8 & 17 & 54 & $\begin{array}{r}27 \\
(63)\end{array}$ & 1.2 & 0.4 & 3.3 & $\begin{array}{r}3.6 \\
(2.5)\end{array}$ & 56.1 & 47.7 & 50.6 & 58.6 & $\begin{array}{r}-2.5 \\
(13.9)\end{array}$ \\
\hline
\end{tabular}

PBLs were allowed to recover after challenge for $20 \mathrm{~h}$ in presence of cytochalasin B.

$\because$ Three repeated measurements (day-to-day variation) with regard to the effect of $( \pm$ )-anti-BPDE pre-exposure on ( \pm )-anti-BPDE challenge-induced MN were performed on PBLs obtained from donors 1 and 2. Donor 1: mean ( $\pm \mathrm{SD}$ ) observed number of $\mathrm{MN}: 11.0 \pm 4.4$; mean $( \pm \mathrm{SD}$ ) expected number of $\mathrm{MN}: 18.7 \pm 2.5$. Donor $2:$ mean $( \pm \mathrm{SD}$ ) observed number of $\mathrm{MN}: 12.0 \pm 5.0 ;$ mean $( \pm \mathrm{SD})$ expected number of $\mathrm{MN}: 8.7 \pm 6.0$ 
In Table 6.1, the effects of ( \pm )-anti-BPDE pre-exposure on challenge-induced $\mathrm{MN}$, UDS and decrease of $\mathrm{NAD}^{+}$-levels are shown for PBLs obtained from all 10 donors. For each donor, MN, UDS and $\mathrm{NAD}^{+}$-values were obtained within the course of the same experiment. For donor 1 and donor 2, repeated measurements were performed on different days with regard to the effect of pre-exposure on challenge-induced MN (Table 6.1, legend). A preventive effect of pre-exposure to $2.5 \mathrm{nM}( \pm)$-anti-BPDE on ( \pm -anti-BPDE-induced MN formation was repeatedly observed for PBLs obtained from donor 1. For PBLs, obtained from donor 2, a minor preventive effect of pre-exposure was detectable once out of three experiments (which is shown in Figure 6.2). In the two other experiments performed with PBLs from this donor, pre-exposure potentiated more or less the challenge-induced $\mathrm{MN}$ formation.

Concerning the effect of pre-exposure on challenge-induced $\mathrm{MN}$ for all donors, a very clear preventive effect of pre-exposure on $\mathrm{MN}$ formation was observed for PBLs obtained from donors 1, 3, 7 and donor 10. Pre-exposure tended to have no (donor 8) or even a more or less additive or synergistic effect on challenge-induced MN in PBLs obtained from other donors (donors 2, 4, 5, 6, 9). In general, pre-exposure by itself had no or little effect on induction of MN frequencies.

PBLs obtained from donor 1 up to and including 4 were also allowed to recover for $30 \mathrm{~h}$ in presence of cyt B, after challenge. No preventive effect of preexposure was observed after recovery for $20 \mathrm{~h}$ in presence of cyt B (donors 2 and 4 ), nor after recovery for $30 \mathrm{~h}$. With this prolonged recovery time however, cytotoxic effects became apparent, as indicated by an increase in cellular debris and reduction in the number of binucleated cells.

Pre-exposure by itself had little effect on the induction of UDS. Concerning the effect of pre-exposure on ( \pm )-anti-BPDE-induced DNA repair, for 6 donors UDS levels were higher than expected (donors 2, 4, 6, 7, 8 and 10). For the other donors, pre-exposure decreased challenge-induced UDS levels (donor 1 ) or had little or no effect (donors 3, 5, 9).

In PBLs obtained from most donors, $\mathrm{NAD}^{+}$-levels were decreased after challenge for $55 \mathrm{~min}$ in comparison to solvent control treated cells (donors 1, 2, 4, $8,9,10)$. The effect of pre-exposure itself on lymphocytic $\mathrm{NAD}^{+}$-levels is unclear. In pre-exposed PBLs, $\mathrm{NAD}^{+}$-levels were found to be higher (donors $1,3,4,5,6$ ) as well as lower (donors 2, 7, 8, 9, 10) in comparison to levels found in solvent controls. The difference between observed decrease in $\mathrm{NAD}^{+}$-levels and calculated expected decrease in $\mathrm{NAD}^{+}$-levels was only positive for donors 3,6 and 7 . When the actual values were considered for these individuals, no clear decrease in $\mathrm{NAD}^{+}$-levels was observed as a consequence of $( \pm)$-anti-BPDE challenge.

In Table 6.2, results on the effect of pre-exposure on ( \pm )-anti-BPDE-induced poly(ADP-ribosylation) are shown. In PBLs obtained from most individuals, preexposure to $( \pm)$-anti-BPDE or DMSO alone did not result in formation of 
Table 6.2. Effect of ( \pm )-anti-BPDE exposure, during 15 and 35 minutes, on induction of poly(ADP-ribosylation), in isolated peripheral blood lymphocytes, with or without pre-exposure to $2.5 \times 10^{-3} \mu \mathrm{M}( \pm)$-anti-BPDE. $\varepsilon$ Rado represents ethenoribosyladenosine. Results of 10 healthy donors are shown.

\begin{tabular}{|c|c|c|c|c|c|c|c|c|c|}
\hline \multirow[t]{2}{*}{ donor } & $\begin{array}{l}\text { ( } \pm \text { )-anti-BPDE } \\
(\mu \mathrm{M})\end{array}$ & \multicolumn{4}{|c|}{$\begin{array}{l}\text { poly(ADP-ribosylation) } \\
\text { after } 15 \text { minutes challenge treatment } \\
\text { (pmol } \varepsilon \text { Rado } / 1 \times 10^{8} \text { cells) }\end{array}$} & \multicolumn{4}{|c|}{$\begin{array}{l}\text { poly(ADP-ribosylation) } \\
\text { after } 35 \text { minutes challenge treatment } \\
\text { (pmol \&Rado } / 1 \times 10^{8} \text { cells) }\end{array}$} \\
\hline & $\begin{array}{l}t=24 \mathrm{~h} \\
t=48 \mathrm{~h}\end{array}$ & $\begin{array}{l}0.0 \\
0.0\end{array}$ & $\begin{array}{l}2.5 \times 10^{-3} \\
0.0\end{array}$ & $\begin{array}{l}0.0 \\
40.0\end{array}$ & $\begin{array}{l}2.5 \times 10^{-3} \\
40.0 \\
\text { (expected) }\end{array}$ & $\begin{array}{l}0.0 \\
0.0\end{array}$ & $\begin{array}{l}2.5 \times 10^{-3} \\
0.0\end{array}$ & $\begin{array}{l}0.0 \\
40.0\end{array}$ & $\begin{array}{l}2.5 \times 10^{-3} \\
40.0 \\
\text { (expected) }\end{array}$ \\
\hline 2 & & 43.0 & 65.9 & 121.4 & $\begin{array}{l}159.1 \\
\mathbf{( 1 4 4 . 3 )}\end{array}$ & 37.3 & 26.1 & 148.8 & $\begin{array}{l}124.0 \\
(137.6)\end{array}$ \\
\hline 3 & & $\mathrm{ND}^{*}$ & ND & 35.4 & $\begin{array}{l}25.2 \\
(35.4)\end{array}$ & ND & ND & 141.4 & $\begin{array}{l}105.0 \\
\text { (141.4) }\end{array}$ \\
\hline 4 & & ND & ND & 52.2 & $\begin{array}{l}31.7 \\
\mathbf{( 5 2 . 2 )}\end{array}$ & ND & ND & 88.9 & $\begin{array}{l}82.1 \\
(88.9)\end{array}$ \\
\hline 7 & & ND & ND & 63.5 & $\begin{array}{l}45.6 \\
(63.5)\end{array}$ & ND & ND & 83.8 & $\begin{array}{l}74.3 \\
(83.8)\end{array}$ \\
\hline 8 & & ND & ND & ND & $\begin{array}{l}\text { ND } \\
\text { (ND) }\end{array}$ & ND & ND & 118.9 & $\begin{array}{l}107.3 \\
\mathbf{( 1 1 8 . 9 )}\end{array}$ \\
\hline 9 & & - & - & - & - & - & - & - & - \\
\hline 10 & & 22.8 & ND & 23.3 & $\begin{array}{l}50.7 \\
(0.5)\end{array}$ & ND & ND & 10.9 & $\begin{array}{l}71.9 \\
(\mathbf{1 0 . 9 )}\end{array}$ \\
\hline
\end{tabular}

- not detected 
detectable poly(ADP-ribose) polymers, determined $48 \mathrm{~h}$ after initiation of the cultures. Challenge with $40.0 \mu \mathrm{M}( \pm)$-anti-BPDE resulted in evidently elevated poly(ADP-ribosylation), in comparison to solvent control treated cultures. An exception are PBLs, obtained from donor 8 , in which polymer formation could not be detected after $15 \mathrm{~min}$ of ( \pm )-anti-BPDE challenge. When the effect of preexposure on challenge-induced poly(ADP-ribosylation) is considered, only in PBLs obtained from donor 1 and donor 10 observed $\varepsilon$ Rado levels were considerably higher than expected $\varepsilon$ Rado levels. In PBLs obtained from other donors, the degree of poly(ADP-ribosylation), determined in cultures after combined ( \pm )-anti-BPDE-treatment, was lower than or approximately equal as expected, taken into account the intra-assay variation of $~ 3 \%$.

In PBLs obtained from these 10 donors, no significant associations were observed between $\mathrm{MN}$, UDS, $\mathrm{NAD}^{+}$and poly(ADP-ribosylation), using the calculated differences between expected and observed values (Spearman Rank Correlation).

In PBLs, obtained from donor 1 and donor 2, the effect of ( \pm )-anti-BPDE preexposure on challenge-induced $( \pm)$-anti-BPDE- $\mathrm{N}^{2}-\mathrm{dG}$ adduct formation was determined. No adducts were visible in DNA obtained from PBLs treated only with DMSO or with $2.5 \mathrm{nM}( \pm)$-anti-BPDE. Results, obtained from all challenged cultures are shown in Figure 6.3, and expressed as relative ( \pm -anti-BPDE- $\mathrm{N}^{2}$-dG adduct levels. In PBLs, obtained from both donors, pre-exposure to $2.5 \mathrm{nM}( \pm)$ anti-BPDE did not alter significantly the formation of $( \pm)$-anti-BPDE- $\mathrm{N}^{2}-\mathrm{dG}$ adducts, induced by the challenge.

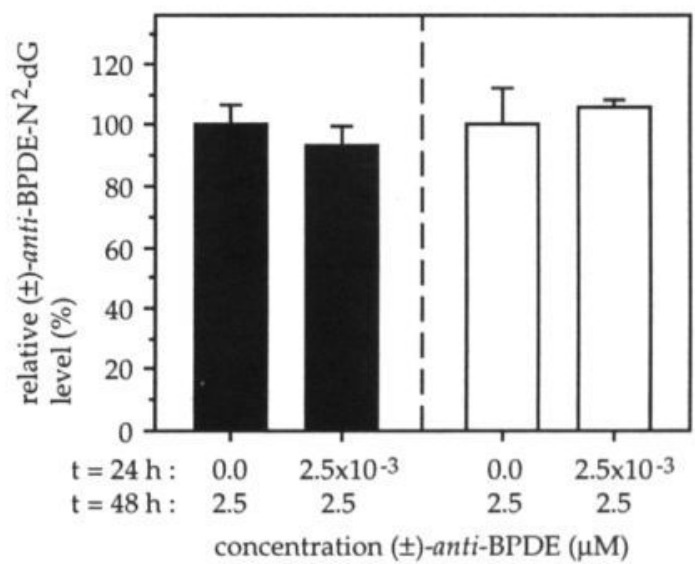

Figure 6.3. Effect of pre-exposure with $2.5 \mathrm{nM}( \pm)$-anti-BPDE on adduct formation by exposure to $2.5 \mu \mathrm{M}( \pm)$-anti-BPDE. Donor 1 :

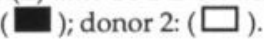




\section{Discussion}

Results from the present study indicate that pre-exposure of PBLs, obtained from some but not all donors, to $( \pm)$-anti-BPDE seems to prevent $\mathrm{MN}$ formation, induced by a higher concentration of $( \pm)$-anti-BPDE at a later time point. Thus, for a subpopulation of responders, pre-exposure of human PBLs with enantiomers of the reactive metabolite from the ultimate carcinogen benzo[a]pyrene is capable of inducing protective mechanisms similar as observed for ionizing radiation and radiomimetic agents.

The fact that $( \pm)$-anti-BPDE induces $\mathrm{MN}$ in human PBLs, indicates that DNA double strand breaks must have been formed sometimes between the time point of initial ( \pm )-anti-BPDE-DNA interaction and block of cytokinesis at the end of mitosis. It is unlikely that interaction directly leads to helix distortion in such a way that double-strand breaks arise. Instead, $( \pm)$-anti-BPDE has been found to induce single-strand breaks in PBLs and Hela cells (31-33), which could be the consequence of action of AP endonucleases on unstable N7-G adducts. In vitro, $( \pm)$-anti-BPDE treatment of isolated DNA resulted in formation of this adduct (34-36). Alternatively, nucleotide excision repair of covalent $( \pm$ )-anti-BPDE-N2 dG adducts temporarily causes formation of single-strand breaks. Nucleotide excision repair-related processes occur in $( \pm)$-anti-BPDE-treated normal human cells (Table 6.1,26,29,31,32,37), but not in ( \pm )-anti-BPDE-treated XP-cells (37). When gap-filling and ligation of base excision repair and/or nucleotide excision repair is not completed prior to the onset of the S-phase, single strand breaks may be converted to daughter strands with double-strand breaks which, when left unrepaired, finally can be demonstrated as MN (38).

As is clear from Figure 6.1, interindividual differences exist in ( \pm )-anti-BPDEinduced $\mathrm{MN}$, which may be related to interindividual differences in repair capacity. Alternatively, in response to stimulation to proliferation by PHA, interindividual differences may arise in cell-cycle distribution. This could result in differential loss of cell populations, which are in an earlier phase than G2, and which are perhaps more sensitive at time of challenge. The occurrence of asynchronous cell-populations, at time of challenge, may also explain the increase in number of MN, when cells were allowed to recover for an additional $10 \mathrm{~h}$ in presence of cyt B (data not shown).

Results show that, whenever $( \pm)$-anti-BPDE pre-exposure induces a preventive effect with regard to challenge-induced $\mathrm{MN}$, it is concentrationdependent. Other studies applying various cytogenetic endpoints, such as chromosomal aberrations and $\mathrm{MN}$, also indicate that the AR in human PBLs, induced by for example MNNG, X-ray, hydrogen peroxide and mitomycin C depends on the concentration during pre-exposure $(8,13,17,20)$.

In PBLs obtained from 2 out of 4 donors, an AR was neither detected after recovery for $20 \mathrm{~h}$ nor after $30 \mathrm{~h}$ in presence of cyt B. Further, with prolonged 
recovery time in presence of cyt B, cytotoxic effects were observed. Therefore, despite the fact that we cannot exclude the possibility that an eventual AR may remain undetected by sampling different subpopulations only at on time point after challenge treatment, no prolonged recovery times in presence of cyt B were applied for the other 6 donors.

When all donors are considered, it is evident that intra- and inter-individual differences exist with regard to the protective effect by $( \pm)$-anti-BPDE preexposure on challenge-induced $\mathrm{MN}$ formation. Inter-individual differences exist in the degree of $\mathrm{AR}$ induced by various pre-conditioning agents for X-rays $(13,39)$ mitomycin C $(17,18)$ and MNNG $(20,40)$. Moreover, Bauchinger et al., (41) reported the absence of an AR for X-rays in PBLs obtained from two donors. These data suggest that induction of different protective DNA repair mechanisms acting on various kinds of DNA damage in PBLs, may be partially genetically predisposed. Given the results obtained from donor 2 (Table 6.1, legend), in whom the preventive effect of pre-exposure was only observable in one out of three repeated experiments, non-genetic factors may also explain part of the recognized intra-individual differences in ( \pm )-anti-BPDE-induced AR.

Only in PBLs, obtained from donor 1 and donor 10, formation of poly(ADPribose) polymers after challenge during 15 and $35 \mathrm{~min}$ with $40.0 \mu \mathrm{M}( \pm)$-anti$\mathrm{BPDE}$ was considerably higher as a consequence of pre-exposure. Also, preexposure resulted in a reduction in the number of $\mathrm{MN}$ induced by $2.5 \mu \mathrm{M}( \pm)$ anti-BPDE in PBLs obtained from these two donors. In these two individuals, the potentiating effect of pre-exposure on induction of poly(ADP-ribosylation) was not reflected by an enhanced decrease of lymphocytic $\mathrm{NAD}^{+}$levels after exposure for $55 \mathrm{~min}$ to $2.5 \mu \mathrm{M}( \pm)$-anti-BPDE. In addition, in PBLs obtained from donor 7, a small preventive effect of pre-exposure with regard to challengeinduced number of $\mathrm{MN}$ was observed, while pre-exposure had no potentiating effect on challenge-induced poly(ADP-ribosylation) or reduction in lymphocytic $\mathrm{NAD}^{+}$-levels. Moreover, when results from all individuals are considered, no associations were found for the differences between expected and observed number of $\mathrm{MN}$ versus the differences between expected and observed induction of poly(ADP-ribosylation) and reduction in NAD+-levels, respectively. Thus, results indicate that induction of an AR by pre-exposure to low levels of $( \pm)$ anti-BPDE might not be linked to induction of processes indicative for poly(ADP-ribose) polymer formation. However, it has to be considered that this may be explained by the difference in challenge doses of $( \pm)$-anti-BPDE, required for the induction of detectable poly(ADP-ribosylation) $(40.0 \mu \mathrm{M})$ and $\mathrm{MN}$ frequencies $(2.5 \mu \mathrm{M})$.

In contrast, poly(ADP-ribose) polymerase inhibitors were found to inhibit the $\left[{ }^{3} \mathrm{H}\right]$ thymidine- $\mathrm{X}$-ray- and bleomycin-induced AR for X-rays in PBLs $(8,10,14,24)$. However, it must be mentioned that in these studies high concentrations of poly(ADP-ribose) polymerase inhibitors were applied which may cause additional cellular metabolic effects (42). 
In some donors, the extent of UDS after combined ( \pm )-anti-BPDE treatment tended to be higher than expected, while no adaptation with regard to $\mathrm{MN}$ was observed (donor 2, 4,6). Also in PBLs, obtained from donor 1, an adaptation with regard to $\mathrm{MN}$ was repeatedly noticed, while the extent of DNA repair synthesis, measured by UDS after combined treatment, even tended to be lower than expected. This suggests that the induction by pre-exposure of certain mechanism(s) involved in excision repair of certain lesions which can be observed as UDS, e.g. long-patch repair of covalent ( \pm -anti-BPDE-DNA adducts, is not responsible for prevention of $( \pm)$-anti-BPDE-induced $\mathrm{MN}$ formation. In addition, pre-exposure did not interfere substantially with challenge-induced $( \pm)$ anti-BPDE- ${ }^{2}$-dG adduct formation, indicating that the observed AR is likely not due to reduction of initial ( \pm )-anti-BPDE-DNA binding.

In conclusion, pre-exposure of PHA-stimulated human PBLs obtained from some but not all individuals, to low levels of $( \pm)$-anti-BPDE results in a decrease in micronuclei frequencies, induced by high ( \pm -anti-BPDE-exposure. Adaptation of DNA repair processes in relation to low environmental exposure to polycyclic aromatic hydrocarbons may therefore occur in human subpopulations in vivo. The preventive mechanism was found to depend on the concentration of ( \pm )-anti-BPDE used during primer treatment. Finally, no clear associations were found between the reducing effects of pre-exposure on micronuclei formation, and the modulation of processes related to DNA excision repair and poly(ADP-ribosylation).

\section{References}

1. Samson, L., Cairns, J. (1977) A new pathway for DNA repair in Echerichia coli, Nature, 267, 281-283.

2. Olivieri, G., Bodycote, J., Wolff, S. (1984) Adaptive response of human lymphocytes to low concentrations of radioactive thymidine. Science, 223, 594-597.

3. Fan, S., Vijayalaxmi, Mindek, G., Burkart, W. (1990) Adaptive response to 2 low doses of X-rays in human blood lymphocytes. Mutat. Res., 243, 53-56.

4. Kelsey, K.T., Memisoglu, A., Frenkel, D., Liber, H.L. (1991) Human lymphocytes exposed to low doses of X-rays are less susceptible to radiation-induced mutagenesis. Mutat. Res., 263, 197-201.

5. Sankaranarayanan, K., Van Duyn, A., Loos, M.J., Natarajan, A.T. (1989) Adaptive response of human lymphocytes to low-level radiation from radioisotopes or $\mathrm{X}$-rays. Mutat. Res., 211, 7-12.

6. Shadley, J.D., Afzal, V., Wolff, S. (1987) Characterization of the adaptive response to ionizing radiation induced by low doses of $\mathrm{X}$ rays to human lymphocytes. Radiat. Res., 111, 511-517.

7. Shadley, J.D., Wiencke, J.K. (1989) Induction of the adaptive response by X-rays is dependent on radiation intensity. Int. J. Radiat. Biol., 56, 107-118.

8. Shadley, J.D., Wolff, S. (1987) Very low doses of X-rays can cause human lymphocytes to become less susceptible to ionizing radiation. Mutagenesis, 2, 95-96.

9. Wang, Z.-Q., Saigusa, S., Sasaki, M.S. (1991) Adaptive response to chromosome damage in cultured human lymphocytes primed with low doses of X-rays. Mutat. Res., 246, 179-186. 
10. Vijayalaxmi, Burkart, W. (1989) Effect of 3-aminobenzamide on chromosome damage in human blood lymphocytes adapted to bleomycin, Mutagenesis, 4, 187-189.

11. Vijayalaxmi, Burkart, W. (1989) Resistance and cross-resistance to chromosome damage in human blood lymphocytes adapted to bleomycin. Mutat. Res., 211, 1-5.

12. Cortés, F., Domínguez, I., Piñero, J., Mateos, J.C. (1990) Adaptive response in human lymphocytes conditioned with hydrogen peroxide before irradiation with X-rays. Mutagenesis, 5, 555-557.

13. Domínguez, I., Panneerselvam, N., Escalza, P., Natarajan, A.T., Cortés, F. (1993) Adaptive response to radiation damage in human lymphocytes conditioned with hydrogen peroxide as measured by the cytokinesis-block micronucleus technique. Mutat. Res., 301, 135-141.

14. Wiencke, J.K., Afzal, V., Olivieri, G., Wolff, S. (1986) Evidence that the $\left[{ }^{3} \mathrm{H}\right]$ thymidine-induced adaptive reponse of human lymphocytes to subsequent doses of X-rays involves the induction of a chromosomal repair mechanism. Mutagenesis, 1, 375-380.

15. Cai, L., Liu, S.Z. (1992) Study on the mechanism of cytogenetic adaptive response induced by low dose radiation. Chin. Med. J. Engl., 105, 277-283.

16. Wolff, S., Jostes, R., Cross, F.T., Edmund Hui, T., Afzal, V., Wiencke, J.K. (1991) Adaptive response of human lymphocytes for the repair of radon-induced chromosomal damage. Mutat. Res., 250, 299-306.

17. Madrigal-Bujaidar, E., Cassani, M., Martínez, S., Morales, T. (1994) Adaptive response induced by mitomycin $\mathrm{C}$ measuring the frequency of SCEs in human lymphocyte cultures. Mutat. Res., 322, 301-305.

18. Moquet, J.E., Prosser, J.S., Edwards, A.A., Lloyd, D.C. (1989) Sister-chromatid exchanges induced by mitomycin $\mathrm{C}$ after acute or chronic exposure of human lymphocytes to a low dose of X-rays. Mutat. Res., 227, 207-213.

19. Wolff, S., Afzal, V., Wiencke, J.K., Olivieri, G., Michaeli, A. (1988) Human lymphocytes exposed to low doses of ionizing radiations become refractory to high doses of radiation as well as to chemical mutagens that induce double-strand breaks in DNA. Int. J. Radiat. Biol. Relat. Stud. Phys. Chem. Med., 53, 39-47.

20. Morimoto, K., Sato-Mizuno, M. Koizumi, A. (1986) Adaptation-like response to the chemical induction of sister chromatid exchanges in human lymphocytes. Hum. Genet., 73, 81-85.

21. Youngblom, J.H., Wiencke, J.K., Wolff, S. (1989) Inhibition of the adaptive response of human lymphocytes to very low doses of ionizing radiation by the protein synthesis inhibitor cycloheximide. Mutat. Res., 227, 257-261.

22. Rankin, P.W., Jacobson, E.L., Benjamin, R.C., Moss, J., Jacobson, M.K. (1989) Quantitative studies of inhibitors of ADP-ribosylation in vitro and in vivo. J. Biol. Chem., 264, 4312-4317.

23. Sims, J.L., Sikorski, G.W., Catino, D.M., Berger, S.J., Berger, N.A. (1982) Poly(adenosinediphosphoribose) polymerase inhibitors stimulate unscheduled deoxyribonucleic acid synthesis in normal human lymphocytes. Biochemistry, 21, 1813-1821.

24. Wiencke, J.K. (1987) Nicotinamide deficiency in human lymphocytes prevents the $\left[{ }^{3} \mathrm{H}\right]$ thymidine-induced adaptive response fro the repair of X-ray-induced chromosomal damage. Exp. Cell. Res., 171, 518-523.

25. Carson, D.A., Seto, S., Wasson, D.B. (1987) Pyridine nucleotide cycling and poly(ADP-ribose) synthesis in resting human lymphocytes. J. Immunol., 138, 19041907.

26. Stierum, R.H., Van Herwijnen, M.H.M., Hageman, G.J., Kleinjans, J.C.S. (1994) Increased poly(ADP-ribose) polymerase activity during repair of ( \pm )-antibenzo[a]pyrene diolepoxide-induced DNA damage in human peripheral blood 
lymphocytes in vitro. Carcinogenesis, 15, 745-751.

27. Fenech, M., Morley, A.A. (1985) Measurement of micronuclei in lymphocytes. Mutat. Res., 147, 29-36.

28. Jacobson, M.K. Payne, D.M., Alvarez-Gonzalez, R., Juarez-Salinas, H., Sims, J.L. Jacobson, E.L. (1984). Determination of in vivo levels of polymeric and monomeric ADP-ribose by fluorescence methods. Methods Enzymol., 106, 483-494.

29. Stierum, R.H., Van Herwijnen, M.H.M., Maas, L.M., Hageman, G.J., Kleinjans, J.C.S. (1994) Measurement by ${ }^{32} \mathrm{P}$-postlabeling of ( \pm )-anti-benzo[a]pyrene-diolepoxide$\mathrm{N}^{2}$-deoxyguanosine adduct persistence in unstimulated human peripheral blood lymphocytes. Mutat. Res., 325, 31-37.

30. Reddy, M.V., Gupta, R.C., Randerath, E., Randerath, K. (1984) ${ }^{32}$ P-postlabeling test for covalent DNA binding of chemicals in vivo: application to a variety of aromatic carcinogens and methylating agents. Carcinogenesis, 5, 231-243.

31. Celotti, L., Ferraro, P., Biasin, M. (1992) Detection by fluorescence analysis of DNA unwinding and unscheduled DNA synthesis, of DNA damage and repair induced in vitro by direct-acting mutagens on human lymphocytes. Mutat. Res., 281, 17-23.

32. Celotti, L., Ferraro, P., Furlan, D., Zanesi, N., Pavanello, S. (1993) DNA repair in human lymphocytes treated in vitro with $( \pm)$-anti- and $( \pm)$-syn-benzo[a]pyrene diolepoxide. Mutat. Res., 294, 117-126.

33. Moran, M.F., Ebisuzaki, K.(1991) In vivo benzo[a]pyrene diol epoxide-induced alkali-labile sites are not apurinic sites. Mutat. Res., 262, 79-84.

34. King, H.W.S., Osborne, M.R., Brookes, P. (1979) The in vitro and in vivo reaction at the N7-position of guanine of the ultimate carcinogen derived from benzo[a]pyrene. Chem. Biol. Interact., 24, 345-353.

35. Osborne, M.R., Jacobs, S., Marvey, R.G., Brookes, P. (1981) Minor products from the reaction of $(+)$ and (-) benzo[a]pyrene-anti-diolepoxide with DNA. Carcinogenesis, 2, 553-558.

36. Osborne, M.R., Merrifield, K. (1985) Depurination of benzo[a]pyrene-diolepoxide treated DNA. Chem. Biol. Interact., 53, 183-195.

37. Yang, L.I., Maher, V.M., McCormick, J.J. (1980) Error-free excision of the cytotoxic, mutagenic $\mathrm{N}^{2}$-deoxyguanosine DNA adduct formed in human fibroblasts by $( \pm)$ $7 \beta, 8 \alpha$-dihydroxy-9 $\alpha, 10 \alpha$-epoxy-7,8,9,10-tetrahydrobenzo-[a]pyrene. Proc. Natl. Acad. Sci. U.S.A., 77, 5933-5937.

38. Fenech, M. (1993) The cytokinesis-block micronucleus technique and its application to genotoxicity studies in human populations. Environ. Health Persp. Suppl., 101, 101-107.

39. Bosi, A., Olivieri, G. (1989) Variability of the adaptive response to ionizing radiations in humans. Mutat. Res., 211, 13-17.

40. Anderson, D., Fisher, P., Jenkinson, P.C., Phillips, B.J. (1988) Studies of the 'adaptive' repair reponse in human lympocytes and V79 cells after treatment with MNNG and MNU. Hum. Toxicol., 7, 337-341.

41. Bauchinger, M., Schmidt, E., Braselman, A., Nahrstedt, A. (1989) Absence of adaptive response to low-level irradiation from tritiated thymidine and X-rays in lymphocytes of two individuals examined in serial experiments. Mutat. Res., 227, 103-107.

42. Milam, K.M., Cleaver, J.E. (1984) Inhibitors of poly(adenosine disphosphate-ribose) synthesis: effect on other metabolic processes. Science, 223, 589-591. 


\section{Inhibition of poly(ADP-ribose) polymerase increases ( \pm )-anti- benzo[a]pyrene diolepoxide-induced micronuclei formation and p53 accumulation in isolated human peripheral blood lymphocytes}

R.H. Stierum, M.H.M. van Herwijnen, P.C. Pasman*, G.J. Hageman, J.C.S. Kleinjans and B. van Agen

Department of Health Risk Analysis and Toxicology, University of Limburg, P.O. Box 616, 6200 MD, Maastricht, The Netherlands

* Department of Internal Medicine. Hematology/Oncology section, University Hospital Maastricht, The Netherlands

Based on: Carcinogenesis, 16, 2765-2771, 1995

\section{Abstract}

In response to DNA damage, in particular DNA strand breaks, the proposed roles for normal tumour suppressor protein p53 are to increase the period of time available for DNA repair prior to replication, or to direct damaged cells into programmed cell-death. Since treatment of mammalian cells with $( \pm)$-antibenzo[a]pyrene diolepoxide $(( \pm)$-anti-BPDE) -a mixture of metabolites comprising the most reactive (+)-anti-enantiomer of the full environmental carcinogen benzo[a]pyrene- has been shown to result in DNA strand break formation, aim of the present study was to investigate whether p53 accumulation is induced in $( \pm)$-anti-BPDE-treated phytohemagglutininstimulated human peripheral blood lymphocytes (PBLs). Both immunocytochemical and immunoblot analysis indicated that treatment of PBLs with $( \pm$ )-anti-BPDE results in p53 accumulation. Optimal accumulation was observed at $2.5 \mu \mathrm{M}$, while no increase of p53 levels was observed at concentrations lower than $2.5 \mu \mathrm{M}$ and higher than $10 \mu \mathrm{M}$. Further, $( \pm)$-antiBPDE-induced p53 accumulation in PBLs was found to be dependent of the exposure duration, with accumulation up to $24 \mathrm{~h}$ of treatment. Treatment of PBLs with $2.5 \mu \mathrm{M}$ of $( \pm)$-anti-BPDE and $1 \mathrm{mM}$ of 3 -aminobenzamide, an inhibitor of the DNA strand break-dependent enzyme poly(ADP-ribose) 
polymerase, resulted in increased p53 levels, in comparison to cells treated with $( \pm)$-anti-BPDE alone. This combination also potentiated the frequency of $( \pm)$ anti-BPDE-induced micronuclei. These findings suggest that $( \pm)$-anti-BPDEinduced DNA strand break formation is responsible for the observed p53 accumulation. It is concluded that $\mathrm{p} 53$ accumulation may implicate a protective mechanism in polycyclic aromatic hydrocarbon-treated human peripheral blood lymphocytes. It is unlikely that poly(ADP-ribose) polymer formation is a prerequisite in the process of p53 accumulation, as triggered by DNA strand-break inducing agents like $( \pm)$-anti-BPDE.

\section{Introduction}

The p53 protein was initially identified as part of a protein complex with large $T$ antigen in SV-40 transformed cells (1). Later, it was demonstrated that p53 is a tumour suppressor gene. First, approximately $60 \%$ of all human cancers have p53 gene mutations. In most cases, these alterations consist of missense mutations with loss of heterozygosity (2), thus resulting in loss of normal functional p53 protein during tumorigenesis. Especially individuals with LiFraumeni syndrome (3), having inherited defects in one of the p53 alleles, are predisposed to cancer. Secondly, mice with mutant or absent p53 gene alleles develop tumours at higher frequency that normal mice (4).

When treated with agents that cause DNA damage, for example UV radiation (5-7); $\gamma$-rays (8-10); bleomycin, actinomycin D (11); MMS (12); mitomycin C, cisplatin and nucleotide analogues (13-14), mammalian cells respond by enhancement of intranuclear p53 protein levels. The introduction of strand breaks into DNA is assumed to initiate this process (11).

Accumulation of p53 levels, under conditions of DNA damage, may result in increased transcription of at least three downstream effector genes with p53 responsive elements: WAF1/CIP1 (15); Gadd45 (10,16-17) and $m d m 2$ (18-20). The $21 \mathrm{kDa}$ gene product of WAF1/CIP1 inhibits the activity of cyclin-dependent kinases (21) which in turn prevents G1 to S-phase transition. Activation of this mechanism could provide more time for repair of DNA damage prior to DNA replication (9). In line, cells lacking p53 fail to undergo G1 arrest in response to $\gamma$ ray-induced DNA damage $(8,22)$. Also, enhanced p53 levels may contribute to DNA damage-induced programmed cell-death $(9,13,23)$, by repressing other genes like $b c l-2$ the products of which inhibit apoptosis. Thus, p53 accumulation may prevent the onset of carcinogenesis by selection against heavily damaged cells, in favour of efficiently repaired cells (24).

Treatment of mammalian cells with ( \pm )-anti-benzo[a]pyrene diolepoxide $(( \pm)$ anti-BPDE), a mixture of metabolites comprising the most reactive enantiomer of the full environmental carcinogen benzo[a]pyrene, results in DNA strand break formation and induction of DNA repair processes (25-34). In a previous 
study, we have shown that, after treatment of isolated human peripheral blood lymphocytes with ( \pm )-anti-BPDE, the activity of the DNA repair enzyme poly(ADP-ribose) polymerase [NAD ${ }^{+}$ADP-ribosyltransferase, EC 2.4.2.30] (PADPRT) is rapidly induced (35). This enzyme catalyzes rapid transfer of adenosine diphosphate ribose units from nicotinamide adenine dinucleotide to linear and branched poly(ADP-ribose) polymers. Histones and other proteins, including PADPRT itself, are acceptor molecules for poly(ADP-ribose) polymers. An absolute requirement for this enzyme activation is the presence of DNA single or double strand breaks (36).

Thus, it seems likely that, besides ionizing radiation and chemotherapeutic agents, reactive metabolites of polycyclic aromatic hydrocarbons can also trigger p53 dependent DNA-damage inducible pathways. As indicated, poly(ADPribosylation) and p53 accumulation both require the presence of DNA strand breaks. Further, in mammalian cells treated with DNA damaging agents, poly(ADP-ribose) polymer formation occurs within minutes $(35,37)$ while accumulation of p53 can only be demonstrated after one to several hours $(7,13)$. Therefore, poly(ADP-ribosylation) may represent one of the first steps in the cascade leading to DNA damage-induced p53 accumulation. At present, it is unknown which process(es) translate(s) the signal of DNA strand breaks into p53 protein accumulation.

Aim of the present study was therefore to investigate whether ( \pm -anti-BPDE treatment induces nuclear p53 accumulation in isolated human peripheral blood lymphocytes. Further, the possible involvement of poly(ADP-ribose) polymer formation in this process, in relation to DNA strand breaks and chromosomal damage as determined by micronuclei frequencies, was studied.

\section{Materials and methods}

All chemicals were from Sigma (Axel, the Netherlands), unless otherwise specified. All cell culture media and supplements were obtained from Gibco (Europe) (for PBLs) and Life Technologies (Europe) (for BEAS-2B).

\section{Subjects, isolation of peripheral blood lymphocytes and cell culturing}

$10 \mathrm{ml}$ of heparinized venous blood samples were collected from 8 healthy nonsmoking male human volunteers. All subjects had officially agreed to donate blood by giving their written informed consent. Average age, alcohol and coffee consumption of the subjects were respectively: $25.1 \pm 3.4$ years; $4.0 \pm 3.0$ glasses/week; $2.9 \pm 2.3 \mathrm{cups} /$ day (mean $\pm \mathrm{SD}$ ). Blood was diluted by an equal volume of RPMI 1640 medium, prior to isolation of PBLs on Lymphoprep ${ }^{\mathrm{TM}}$ (Nycomed, Norway). After centrifugation for $15 \mathrm{~min}$ at $800 \mathrm{~g}$, interfaces were collected and washed twice with RPMI 1640 medium. Mononuclear cells were counted and cell suspensions were adjusted to a density of $1-2 \times 10^{6}$ cells $/ \mathrm{ml}$ RPMI 1640 medium which was supplemented by $15 \%$ (v/v) FCS, L-glutamine, 
$100 \mathrm{U} / \mathrm{ml}$ penicillin, $100 \mu \mathrm{g} / \mathrm{ml}$ streptomycin. Cells were cultured in presence of $40 \mu \mathrm{l}( \pm 52 \mu \mathrm{g}) \mathrm{PHA} / \mathrm{ml}$ medium in $10 \mathrm{ml}$ culture tubes in a humidified incubator at $37^{\circ} \mathrm{C}$ under $5 \% \mathrm{CO}_{2}$.

SV40-immortalized BEAS-2B human bronchial epithelial cells (BEAS) (38) were kindly provided by Dr. C. C. Harris (NCI, Bethesda, U.S.A.). Cells were cultured in serum-free keratinocyte growth medium, supplemented with 50 $\mu \mathrm{g} / \mathrm{ml}$ bovine pituitary extract, $5 \mathrm{ng} / \mathrm{ml}$ epidermal growth factor, $5 \mu \mathrm{g} / \mathrm{ml}$ human transferrin, $50 \mu \mathrm{g} / \mathrm{ml}$ gentamicin, $250 \mu \mathrm{g} / \mathrm{ml}$ fungizone, $50 \mathrm{ng} / \mathrm{ml}$ hydrocortisone. BEAS-2B cells were grown in plastic cell culture flasks in a humidified incubator at $37^{\circ} \mathrm{C}$ under $5 \% \mathrm{CO}_{2}$.

\section{Chemical treatment of cells}

( \pm -anti-BPDE (( \pm$)-7 \beta, 8 \alpha$-dihydroxy-9 $\alpha, 10 \alpha$-epoxy-7,8,9,10-tetrahydrobenzo[a]pyrene, Midwest Research Institute, U.S.A.) stock solutions were prepared in anhydrous DMSO and stored at $-20^{\circ} \mathrm{C}$ in the dark prior to one-off use. $48 \mathrm{~h}$ after initiation of the cultures, cells were treated with ( \pm )-anti-BPDE or DMSO. PBLs treated with act D served as a positive control. This topoisomerase-targeted compound has been reported to induce p53 accumulation in human myoblastic leukemia cells (8), immortalized mouse fibroblasts (13), and human prostatic adenocarcinoma cells (11). As an additional positive control, SV40-immortalized human bronchial epithelial cells, BEAS-2B, (38) were used. These cells have been shown to contain detectable wild-type p53 protein (39).

In order to study the potential role of poly(ADP-ribosylation) in ( \pm )-antiBPDE-induced DNA damage and p53 accumulation, the PADPRT inhibitor 3aminobenzamide $(37,40)$ was added to PBLs, prior to addition of $( \pm)$-anti-BPDE. For determination of p53 induction, at the respective time points after treatment, cells were washed twice with ice-cold PBS and processed for immunocytochemical staining and immunoblotting. For determination of micronuclei frequencies, PBLs were cultured in duplicate and cytochalasin B was added to a final concentration of $6 \mu \mathrm{g} / \mathrm{ml}$, immediately after addition of ( \pm )-antiBPDE and 3-aminobenzamide. Cells were cultured for another $20 \mathrm{~h}$ prior to harvesting as described under Determination of micronuclei frequencies.

\section{Antibodies}

Rabbit polyclonal antibody CM-1, raised against a full-length recombinant human p53, was kindly provided by Prof. D. Lane (Medical Sciences Institute, Dundee, Scotland). Mouse monoclonal IgG2b antibody DO7, raised against recombinant human 53 protein, was obtained from Novocastra Laboratories (Newcastle upon Tyne, UK).

For immunocytochemical staining a biotinylated goat anti-rabbit IgG (Vector Laboratories, Burlingame, California, U.S.A.) was used as secondary antibody. For immunoblotting, an alkaline phosphatase-conjugated goat anti-rabbit IgG 
(against CM-1) (Vector Laboratories, Burlingame, California, U.S.A.), or a mixture of alkaline-phosphatase-conjugated rabbit anti-mouse antibodies (DAKO, Denmark) (against DO-7) were applied as secondary antibodies.

\section{Immunocytochemistry}

After washing, ethanol $\left(-20^{\circ} \mathrm{C}\right)$ was added drop-wise to a final concentration of $70 \%(\mathrm{v} / \mathrm{v})$, while cultures were gently vortexed. Cultures were stored for $30 \mathrm{~min}$ at $-20{ }^{\circ} \mathrm{C}$ and resuspended in a small volume of $70 \%(\mathrm{v} / \mathrm{v})$ ethanol. Part of the suspension was pipetted on slides and air-dried.

Slides were dehydrated and incubated for $15 \mathrm{~min}$ in $0.3 \% \mathrm{H}_{2} \mathrm{O}_{2}$ in methanol, rinsed with bidest and boiled for $10 \mathrm{~min}$ in $10 \mathrm{mM}$ sodium citrate $\mathrm{pH}$ 6.0. Then, slides were incubated in a humidified atmosphere at room temperature for $1 \mathrm{~h}$ with CM-1 (diluted $1: 500, \mathrm{v} / \mathrm{v}$ ) in $1.5 \%$ normal goat serum in PBS, rinsed in PBS and incubated for 30 min with secondary antibody. After washing with PBS, slides were incubated for $30 \mathrm{~min}$ with fluorescein avidin D (Vector Laboratories, Burlingame, California, U.S.A.) (diluted $1: 500$ in 1.5\% normal goat serum in PBS, v/v) washed, dehydrated, counterstained by propidium iodide and examined for nuclear immunostaining, using a Zeiss Axioskop fluorescence microscope.

\section{Immunoblotting}

After treatment and washing, PBLs were lysed, at a density of $1 \times 10^{6} / 40 \mu \mathrm{l}$ lysis buffer containing $6 \mathrm{mM}$ Tris- $\mathrm{HCl} \mathrm{pH} 6.8,2 \mathrm{mM}$ EDTA, $10 \%$ glycerol, $0.1 \%$ sodium azide, $2 \mathrm{mM}$ phenylmethylsulfonylfluoride, $0.1 \%$ aprotinin, $3.3 \%$ SDS and $5 \% \beta$ mercaptoethanol. Ureum (final concentration: $6 \% \mathrm{w} / \mathrm{v}$ ) and bromine phenol blue (final concentration: $0.1 \% \mathrm{w} / \mathrm{v}$ ) were added, and lysates were boiled for 10 $\mathrm{min}$. Lysates were centrifuged and proteins in supernatants (equivalent to $8 \times 10^{5}$ cells) were separated on a $10 \%$ SDS-polyacrylamide gel and transferred on to GenescreenPlus ${ }^{\mathrm{TM}}$ nitrocellulose membrane (NEN Research Products, Dupont, Boston, U.S.A.), using a Biorad mini protean $\mathrm{I}^{\mathrm{TM}}$ (Biorad, Europe) system. After drying, membranes were washed for $30 \mathrm{~min}$ with $0.5 \%(\mathrm{w} / \mathrm{v})$ Non Fat Dry Milk (Nutricia, The Netherlands) in $10 \mathrm{mM}$ Tris, $150 \mathrm{mM} \mathrm{NaCl}, 0.05 \%$ Tween, $\mathrm{pH} 8.0$ (NFDM/TBST), rinsed in TBST and incubated for $60 \mathrm{~min}$ with primary antibody (CM-1 or DO7) (diluted $1: 1500, \mathrm{v} / \mathrm{v}$ in NFDM/TBST). Then, membranes were incubated with secondary antibody for $30 \mathrm{~min}(1: 500, \mathrm{v} / \mathrm{v}$ in NFDM/TBST). Thereafter, membranes were washed with $0.1 \mathrm{M}$ Tris, $0.1 \mathrm{M} \mathrm{NaCl}, 50 \mathrm{mM} \mathrm{MgCl}{ }_{2}$, pH 9.0 (B3) and incubated for $1 \mathrm{~h}$ with $22 \mu \mathrm{l}$ 4-nitro blue tetrazolium chloride (Boehringer Mannheim, $100 \mathrm{mg} / \mathrm{ml}$ ) and $17 \mu \mathrm{l}$ 5-bromo-4-chloro-3-indolylphosphate (Boehringer Mannheim, $50 \mathrm{mg} / \mathrm{ml}$ ) in $5 \mathrm{ml} \mathrm{B}$, in the dark. To stop precipitation, membranes were washed in $20 \mathrm{mM}$ Tris, $5 \mathrm{mM} \mathrm{HCl} \mathrm{pH} 8.0$ and airdried. 


\section{Determination of micronuclei frequencies}

At the end of the culturing period, cultures were hypotonized for $10 \mathrm{~min}$ in 75 $\mathrm{mM} \mathrm{KCl}$ and fixed with methanol : acetic acid $(3: 1, \mathrm{v} / \mathrm{v})$. Slides were prepared and stained for $20-30$ min with $3 \%$ Giemsa. Prior to microscopic analysis, slides were encoded and for each variable, at least 1000 binucleated cells were analyzed for the presence of micronuclei. No distinction was made between binucleated cells with one or more than one micronuclei. Slides were analyzed by one welltrained observer and double-checked by an independent second observer.

\section{Results}

PBLs obtained from two healthy human donors were treated with ( \pm -anti-BPDE in concentrations ranging from $0.0 \mu \mathrm{M}$ to $40.0 \mu \mathrm{M}$ and harvested $24 \mathrm{~h}$ after addition of the carcinogen. In solvent-control treated PBLs obtained from both donors, a faint background staining covering both cytoplasma and nucleus was observable in all cells. When .cells were treated with 0.01 or $0.1 \mu \mathrm{M}( \pm)$-antiBPDE, only an extremely small increase in nuclear immunofluorescence could be seen. Treatment with higher concentrations of $( \pm)$-anti-BPDE $(2.5 \mu \mathrm{M}$ and 10.0 $\mu \mathrm{M})$ evidently resulted in increased immunofluorescence, in comparison to solvent control treated cells, within nuclei of some, but not all lymphocytes. (Figure 7.1). Also, treatment of PBLs with $2.5 \mu \mathrm{M}( \pm$ )-anti-BPDE resulted in increased micronuclei frequencies (Figure 7.5). When PBLs were treated with 40.0 $\mu \mathrm{M}( \pm)$-anti-BPDE, no positively stained cells were visible anymore. A repeated experiment, within a period of two months, performed on PBLs from one of these donors, yielded similar results. Immunoblotting of lysates from $( \pm)$-antiBPDE-treated PBLs confirms detectable induction of p53 accumulation after treatment of PBLs with 2.5 or $10 \mu \mathrm{M}( \pm)$-anti-BPDE, for $24 \mathrm{~h}$ (Figure 7.2).

Concerning the positive controls, treatment of PBLs with $2.0 \mu \mathrm{M}$ act D during $24 \mathrm{~h}$ resulted in all 8 donors in increased nuclear accumulation of p53 (Figure 7.3, data shown for one donor). Further, in untreated SV-40 transformed BEAS-2B cells, p53 protein was detected (Figures 7.2-7.4). No immunocytochemical staining was detectable in ( \pm )-anti-BPDE-treated PBLs, when incubation with primary antibody was omitted.

In PBLs, obtained from donor 1 and donor 2, induction of nuclear p53 accumulation was found to depend on the exposure duration. After treatment for $35 \mathrm{~min}$ with $2.5 \mu \mathrm{M}( \pm)$-anti-BPDE, only minor nuclear p53 accumulation was visible in a few PBLs. With incubation periods up to $24 \mathrm{~h}$, both intensity of nuclear staining and number of stained nuclei increased. At any time point cellular heterogeneity was observed with regard to nuclear p53 accumulation. Immunoblot analysis (Figure 7.3) confirms the time-dependency of ( \pm )-antiBPDE-induced p53 accumulation in human PBLs.

In PBLs obtained from the 6 additional donors, increased nuclear accumulation of p53 was again observed when cells were treated with $2.5 \mu \mathrm{M}$ 


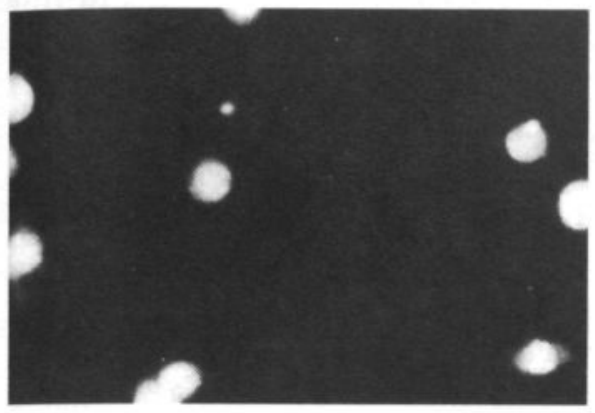

DMSO

(magnification 1000x)

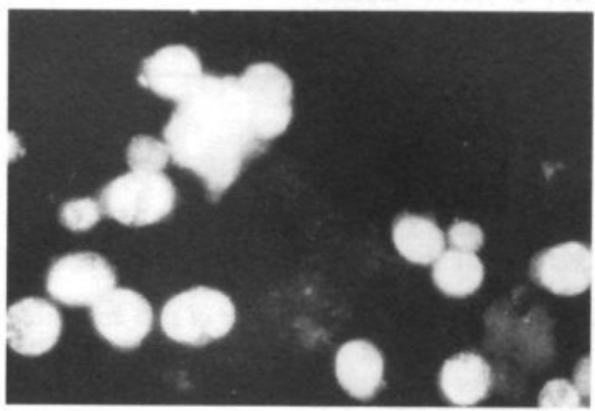

$2.5 \mu \mathrm{M}( \pm)$-anti-BPDE (magnification 1000x)

Figure 7.1. Cellular heterogeneity in induction of nuclear p53 accumulation in PHA-stimulated PBLs after treatment for $24 \mathrm{~h}$ with DMSO or $2.5 \mu \mathrm{M}( \pm)$-anti-BPDE. Cells were processed for immunocytochemistry as described under Materials and methods, using antibody CM-1.

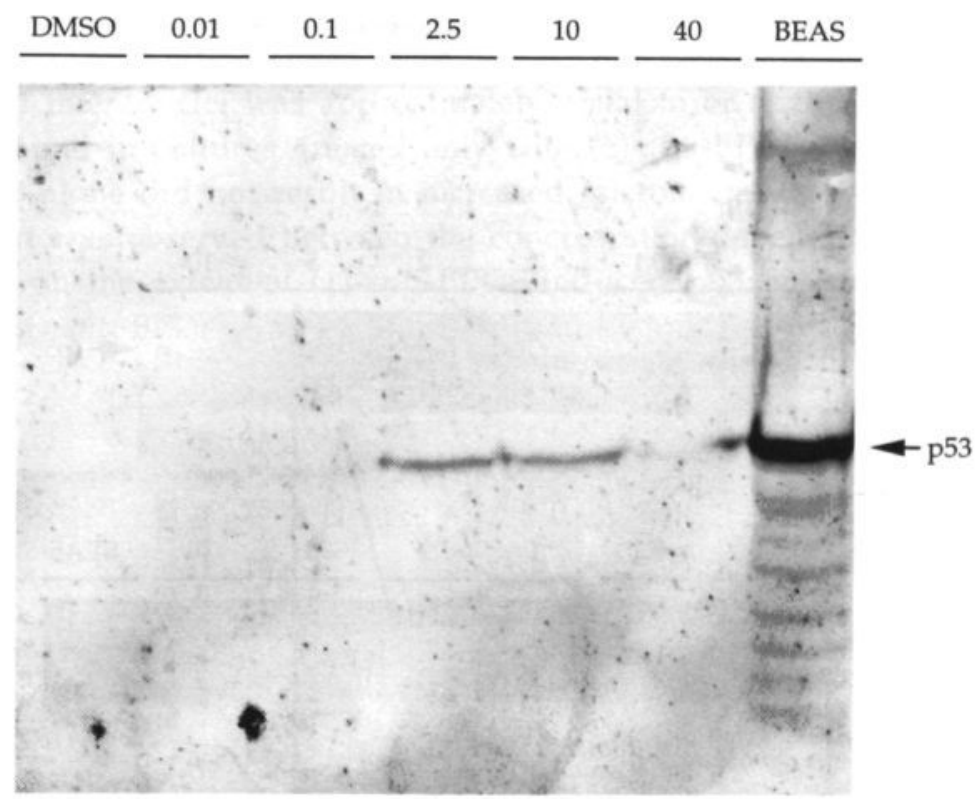

Figure 7.2. Determination of p53 accumulation in PHA-stimulated PBLs after treatment for $24 \mathrm{~h}$ with various concentrations $(\mu \mathrm{M})$ of $( \pm)$-anti-BPDE. Cellular proteins (equivalents of $8 \times 10^{5}$ cells/lane) were separated by SDS-polyacrylamide gelelectrophoresis, transferred to GenescreenPlus ${ }^{\mathrm{TM}}$ nitrocellulose, incubated with CM-1 and alkaline phosphatase-conjugated goat anti-rabbit IgG, and developed. Right lane shows basal p53 levels in untreated SV40-immortalized human bronchial epithelial cell line BEAS-2B. 


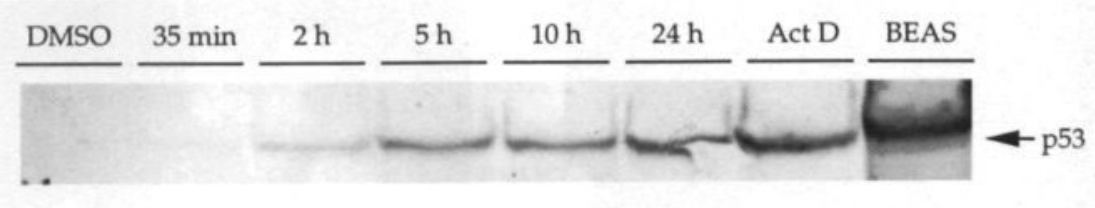

Figure 7.3. Time-dependency of p53 accumulation in PHA-stimulated PBLs, after treatment with 2.5 $\mu \mathrm{M}( \pm)$-anti-BPDE. Immunoblot analysis was performed similarly as described in Figure 7.2. Two right lanes show p53 levels in PBLs treated for $24 \mathrm{~h}$ with $2.0 \mu \mathrm{M}$ act D and p53 levels in untreated SV40-immortalized human bronchial epithelial cell line BEAS-2B.

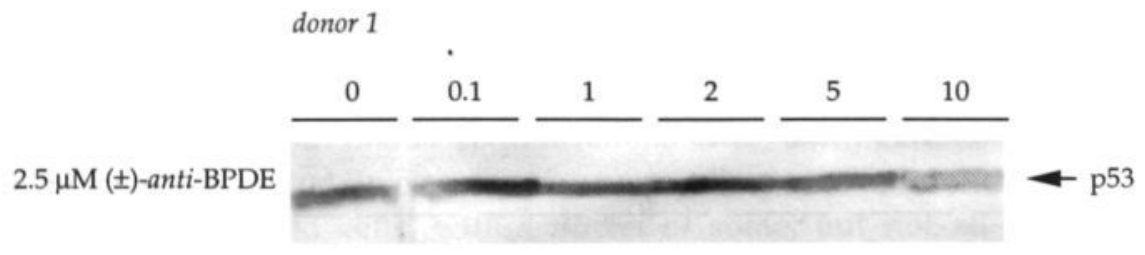

donor 2

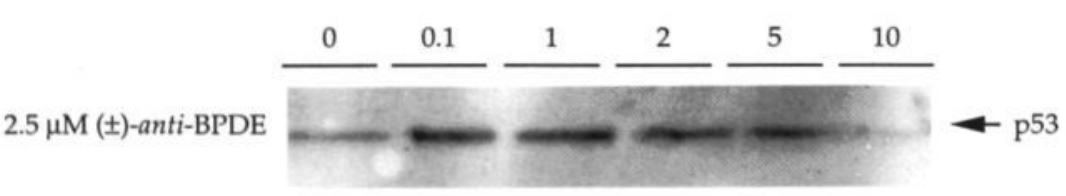

$0 \mu \mathrm{M}( \pm)$-anti-BPDE

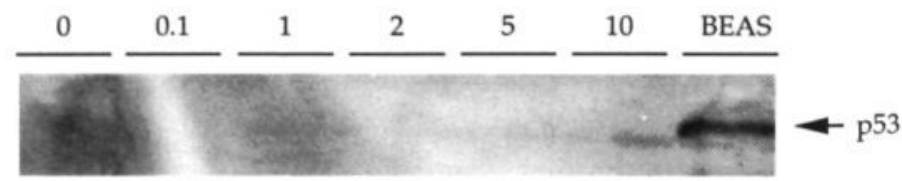

Figure 7.4. Effect of inhibition of PADPRT on ( \pm -anti-BPDE-induced p53 accumulation. PBLs obtained from two donors were treated for $24 \mathrm{~h}$ with $2.5 \mu \mathrm{M}( \pm)$-anti-BPDE, in combination with various concentrations $(\mathrm{mM})$ of $3-\mathrm{AB}$. Determination of $\mathrm{p} 53$ levels was performed similarly as described in Figure 7.2, except that DO-7 was used as primary antibody, in combination with alkaline-phosphatase-conjugated rabbit anti-mouse antibodies. 3-AB treatment alone did not result in detectable p53 accumulation (lower lanes). Lower right lane shows basal p53 levels in untreated SV40-immortalized human bronchial epithelial cell line BEAS-2B. 
( \pm -anti-BPDE for $24 \mathrm{~h}$ and processed for immunocytochemistry.

Figure 7.4 displays the effect of inhibition of poly(ADP-ribosylation) on ( \pm )anti-BPDE-induced p53 accumulation. When PBLs were treated with 3-AB alone, no induction of $\mathrm{p} 53$ accumulation was detected. Combined treatment of PBLs, obtained from two donors, with $2.5 \mu \mathrm{M}( \pm)$-anti-BPDE and low concentrations of $3-\mathrm{AB}$ (up to $1-2 \mathrm{mM}$ ) for $24 \mathrm{~h}$ resulted in increased accumulation of p53 in comparison to treatment with $( \pm)$-anti-BPDE alone. When higher concentrations of 3-AB were applied (5-10 mM), ( \pm -anti-BPDEinduced p53 accumulation gradually decreased below levels found in PBLs, treated with $( \pm)$-anti-BPDE alone. A similar effect of $3-\mathrm{AB}$ treatment on $( \pm)$ anti-BPDE-induced p53 accumulation was observed when PBLs, obtained from donor 1 , were treated for a shorter period, e.g. $5 \mathrm{~h}$ (not shown).

In Figure 7.5, the effect of PADPRT inhibition on ( \pm )-anti-BPDE-induced micronuclei, as marker of DNA strand breakage and chromosomal damage, is shown. Treatment of PBLs with $2.5 \mu \mathrm{M}( \pm)$-anti-BPDE evidently resulted in increased micronuclei frequencies, in comparison to solvent control treated PBLs. When PBLs were treated with $2.5 \mu \mathrm{M}( \pm)$-anti-BPDE in combination with $1 \mathrm{mM} 3-\mathrm{AB}$, a more than 2 -fold increase in micronuclei frequencies was observed, in comparison to treatment with ( \pm )-anti-BPDE alone. When higher concentrations $3-\mathrm{AB}$ were used in combination with $2.5 \mu \mathrm{M}( \pm)$-anti-BPDE, the number of micronuclei was approximately equal to or slightly higher than the number found in cultures, treated only with ( \pm )-anti-BPDE. Treatment of PBLs with $3-\mathrm{AB}$ alone did not result in increased micronuclei frequencies. No direct association was observed between the concentration-dependent effects of 3-AB treatment on the extent of $( \pm)$-anti-BPDE-induced p53 accumulation and the extent of ( \pm )-anti-BPDE-induced MN induction (Figure 7.4 and Figure 7.5).

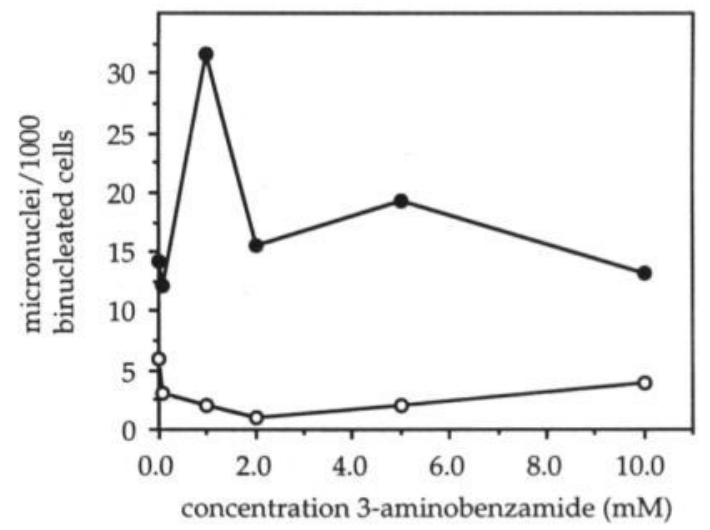

Figure 7.5. Effect of inhibition of PADPRT on ( \pm -anti-BPDE-induced micronuclei in PHA-stimulated PBLs. Cells were treated with DMSO (O ) or $2.5 \mu \mathrm{M}( \pm)$-antiBPDE (-) in combination with various concentrations of 3-AB. Results are obtained from duplicate cultures and expressed as number of micronuclei per 1000 binucleated cells. 


\section{Discussion}

In this study, evidence is presented that treatment of isolated human peripheral blood lymphocytes with ( \pm )-anti-benzo[a]pyrene diolepoxide results in nuclear accumulation of tumour suppressor protein p53. A dose dependent induction of p53 accumulation was observed. Maximal induction of p53 accumulation was observed when cells were treated with $2.5 \mu \mathrm{M}( \pm)$-anti-BPDE, while treatment with lower concentrations did not induce detectable p53 accumulation. p53 accumulation was absent when PBLs were treated with concentrations of ( \pm )anti-BPDE higher than $10 \mu \mathrm{M}$. In addition, treatment with $2.5 \mu \mathrm{M}( \pm)$-antiBPDE caused a clear increase in micronuclei frequencies in cytokinesis-blocked PBLs.

$( \pm)$-anti-BPDE treatment of naked DNA in vitro and of mammalian cells ex vivo has been shown to cause formation of several DNA adducts, including stable $\mathrm{N}^{2}$-deoxyguanosine, unstable $\mathrm{N} 7$-guanine as well as deoxycytidine and deoxyadenosine adducts $(26,27,41-43)$. Action of AP-endonucleases on unstable N7-guanine adducts or action of nucleotide excision repair mechanisms on covalent $\mathrm{N}^{2}$-dG adducts may result in DNA single strand break formation. In ( \pm )anti-BPDE treated mammalian cells, DNA excision repair phenomena and DNA strand break formation have been observed $(26,29,31,33,34,44)$. Besides being related to possible carcinogen-disturbed mitotic spindle formation, $( \pm)$ anti-BPDE-induced micronuclei may therefore reflect unrejoined single strand breaks that may have been converted to double strand breaks during the S-phase that precedes the cytokinesis-blocked mitosis.

Treatment of PBLs with $2.5 \mu \mathrm{M}( \pm)$-anti-BPDE resulted both in p53 accumulation and increased micronuclei frequencies. Further, treatment of PBLs with $1.0 \mathrm{mM} \mathrm{3-AB}$ in combination with $2.5 \mu \mathrm{M}( \pm)$-anti-BPDE resulted both in increased p53 accumulation and increased micronuclei frequencies in comparison to treatment with $( \pm)$-anti-BPDE alone. Other studies also report potentiation of the extent of DNA strand break formation and chromosomal damage induced by DNA damaging agents, in presence of PADPRT inhibitors (45-48). Taken together, the present findings are in line with the concept that carcinogen-induced p53 accumulation requires the presence of DNA strand breaks (11).

The number of micronuclei may be a resultant of initial DNA strand break formation and of adequate rejoining of these breaks prior to the S-phase, that precedes the particular mitosis at the end of which cytokinesis is blocked. Since p53 accumulation may trigger a G1 cell-cycle arrest (24), it can be hypothesized that, despite the fact that initial single strand breaks may accumulate with increasing concentrations of $( \pm)$-anti-BPDE, increased time provided for strand break-rejoining prior to DNA replication prevents the eventual conversion of these breaks to micronuclei. When PBLs, obtained donor 1 and donor 2 were 
treated with varying concentrations of (t)-anth-bPDE, micronuclei frequenctes did not increase to a great extent between $1.0 \mathrm{mM}$ and $25 \mathrm{~mW}$ (unpublished results/Chapter 6. This may implicate that the observed pos accumblation (which was found to be maximal at $2.5 \mathrm{mM}$. within the cencentration range pf (士)-imti-BPDE applied here) indeed prolonged time fet repait and thus prevented further micronuclei formation. However, since (t)-anti-BDDE may also be cytotoxic (49) or induce apoptosis (50) preterential removal of damaged cells prior to fixation may also explain why microtuclei frequencies were not found to increase further.

With concentrations of $3-\mathrm{AB}$ higher than $1 \mathrm{mM}(2 \mathrm{mM}$ up to $10 \mathrm{mM})$, both the frequency of $( \pm)$-anti-BPDE-induced micronuclei and $( \pm)$-anth-BPDE-induced p53 accumulation decreased to similar or lower levels, respectively, as found in cultures treated with ( 1 )-anti-BPDE alone. Although $3-\mathrm{AB}$ has not been found to be cytotoxic in lymphoid cells at concentrations up to $20 \mathrm{mM}$ additional metabolic effects (inhibition of glucose and methonine incorporation into DNA) have been shown to occur already at $1 \mathrm{mM}$ (51). Given the fact that, at concentrations of $3-\mathrm{AB}$ higher than $1 \mathrm{mM}$, the decrease in $( \pm)$-anti-BIDE= induced $\mathrm{MN}$ formation was more abrupt than the decrease in (4)-anti-BPDEinduced $p 53$ accumulation, these additional metabolic effects may probably more directly interfere with $( \pm)$-anti-BPDE-induced $\mathrm{MN}$ formation.

In a previous study, using the same experimental model and donors, induction of poly(ADP-ribosylation) and decrease in $\mathrm{NAD}^{+}$-levels were observed in PBLs, already within 15 min of treatment with $2.5 \mu \mathrm{M}( \pm)$-anti-BPDE (35). In the present study, induction of p53 accumulation in PBLs was not substantially detected after exposure for 35 minutes to $2.5 \mu \mathrm{M}( \pm)$-anti-BPDE. In vivo in C3H10T1/2 cells, $50 \mu \mathrm{M} 3-\mathrm{AB}$ already resulted in nearly complete inhibition of PADPRT activity (40). Hence, with the experimental protocol applied here for PBLs, it is likely that induction of poly(ADP-ribosylation) precedes p53 accumulation and that $3-\mathrm{AB}$ treatment results in efficient inhibition of poly(ADP-ribosylation). As is clear from Figure 7.4, treatment of PBLs with 2.5 $\mu \mathrm{M}( \pm)$-anti-BPDE in combination with $0.1 \mathrm{mM} \mathrm{3-AB}$ resulted even in increased $( \pm)$-anti-BPDE-induced p53 accumulation. Therefore, it is not likely that poly(ADP-ribose) polymers constitute a signal between translation of accumulated DNA strand breaks, and elevated p53 levels.

Instead, inhibition of PADPRT may indirectly contribute to the observed association between ( \pm )-anti-BPDE-induced DNA strand breaks and increased p53 accumulation. First, 3-AB treatment will prevent poly(ADP-ribose) polymer formation on PADPRT itself. In absence of auto-poly(ADP-ribosylation), the PADPRT remains persistently bound to DNA strand breaks $(52,53)$, preventing these from being rejoined. In turn, this could result in upregulation of other cellular signals involved in DNA-strand break-inducible pathway(s) of p53 accumulation. Kastan et al. (16) found absence of p53 accumulation and Gadd45 
mRNA expression in $\gamma$-ray exposed cells, obtained from patients with the cancerprone disease Ataxia-Telangiectasia. Canman et al. (12) reported suboptimal induction of p53, p21WAF1/CIP1, Gadd 45 and $m d m 2$ proteins in AT cell-lines when exposed to single-strand-break inducing agents but not when exposed to UV-C or topoisomerase inhibitors. Thus, gene products absent in AT cells are required in the cascade from DNA strand-breaks, induced by agents that cause initial strand break formation in a non-enzymatic manner, for example via unstable adduct formation, to p53 accumulation. Whether inhibition of poly(ADP-ribosylation) results in upregulation of these gene products is unknown.

Secondly, inhibition of PADPRT has been shown to prevent $\mathrm{NAD}^{+}$and concomitant ATP depletion after carcinogen treatment (54), thus preserving ATP-pools required for adenylation of amino acids and protein synthesis itself. p53 accumulation, induced by DNA-damaging agents, is not related to enhanced mRNA expression but instead to increased protein stability and ongoing protein synthesis $(8,13)$. Thus, inhibition of poly(ADP-ribosylation) during ( \pm )-antiBPDE-induced DNA strand break formation could permit prolonged energydependent p53 synthesis. Vice versa, $( \pm)$-anti-BPDE-induced intracellular energy-depletion could explain the absence of p53 accumulation when PBLs are treated for several h up to $24 \mathrm{~h}$ with $40 \mu \mathrm{M}( \pm$ )-anti-BPDE alone (Figure 7.2). The latter observation may also be explained in terms of preferential rapid removal of damaged cells, prior to harvesting, by cytotoxicity or p53-mediated apoptosis. In HL-60 cells, $( \pm)$-anti-BPDE treatment has been shown to cause apoptosis within $2 \mathrm{~h}(50)$, which is in agreement with the present observed time-dependent p53 accumulation.

Cellular heterogeneity was observed with regard to ( \pm )-anti-BPDE-induced p53 accumulation, with p53 accumulation even being absent in some PBLs. This is unlikely explained by the existence of asynchronous cell populations, since p53 accumulation was found to be inducible at any point of the cell cycle, at least for UV-treated human fibroblasts (7) and cisplatin treated rodent and monkey cells (13). Applying immunocytochemistry in combination with a polyclonal antibody raised against $( \pm)$-anti-BPDE treated DNA, Van Schooten et al. (55) reported cellular heterogeneity in ( \pm )-anti-BPDE-DNA adduct formation in lymphocytes, when human white blood cells were treated ex vivo with 2.5-10 $\mu \mathrm{M}( \pm)$-antiBPDE. Therefore, inter-cellular differences in initial adduct formation may explain the observed heterogeneity in p53 accumulation.

The phenomenon observed here may implicate that, in humans exposed to environmental polycyclic aromatic hydrocarbons, p53 accumulation represents a protective mechanism. Recently, Bjelogrlic et al. (56) reported increased putative p53 protein in mouse skin, concomitantly with increased BPDE-DNA adduct levels, when $\mathrm{B}[\mathrm{a}] \mathrm{P}$ was applied to the skin. It has to be taken into account that in the present study rather high doses $(2.5 \mu \mathrm{M})$ of $( \pm)$-anti-BPDE were required to elicit detectable p53 accumulation, which are expected to cause formation of 
DNA adducts far beyond levels generally found in PBLs in humans. Based on the results of a previous study, it is estimated that approximately one ( \pm )-anti-BPDE$\mathrm{N}^{2}$-dG adduct per $10^{4}-10^{5}$ nucleotides is formed in PBLs, exposed to $2.5 \mu \mathrm{M}( \pm)$ anti-BPDE (35). Further, Bjelogrlic et al. (56) did not observe any substantial putative p53 accumulation when B[a]P-induced adduct levels in mouse skin were below 1-2 per $10^{6}$ nucleotides. In humans, in coke oven workers substantially exposed to PAH, rather low mean lymphocytic ( \pm -anti-BPDE-N ${ }^{2}$ $\mathrm{dG}$ adduct levels of 4.7 per $10^{8}$ nucleotides have been reported (57). Lewtas et al. (58) observed in human smokers higher adduct levels in lung and heart tissues in comparison to adduct levels in PBLs. Therefore, pathways involving the accumulation of p53 in humans may be limited to metabolically more active cells from target organs exposed to high levels of PAH, like lung, heart and skin.

In conclusion, p53 accumulation may represent a protective mechanism in human peripheral blood lymphocytes exposed to reactive metabolites of benzo[a]pyrene. Further, it is suggested that formation of DNA strand breaks is responsible for the observed p53 accumulation. However, results of this study indicate that it is unlikely that DNA strand break-induced poly(ADP-ribose) polymer formation is required in the cascade of events between intracellular recognition of DNA damage and onset of p53 accumulation. Finally, the significance of this mechanism for humans exposed in vivo to polycyclic aromatic hydrocarbons may be limited to cells from highly exposed target organs.

\section{References}

1. Lane, D.P., Crawford, L.V. (1979) T antigen is bound to a host protein in SV40-transformed cells. Nature, 278, 261-263.

2. Levine, A.J., Perry, M.E., Chang, A., Silver, A., Dittmer, D., Wu, M., Welsh, D. (1994) The 1993 Walter Hubert Lecture: The role of p53 tumour-suppressor gene in tumorigenesis. Br. J. Cancer, 69, 409-416.

3. Li, F.P., Fraumeni, J.F., Mulvihill, J.J., Blattner, W.A., Dreyfus, M.G., Tucker, M.A., Miller, R.M. (1988) A cancer family syndrome in twenty-four kindreds. Cancer Res., 48, 5358-5362.

4. Donehower, L.A., Harvey, M., Slagle, B.L., McArthur, M.J., Montgomery, Jr., C.A., Butel, J.S., Bradley, A. (1992) Mice deficient for p53 are developmentally normal but susceptible to spontaneous tumours. Nature, 356, 215-221.

5. Maltzman, W., Czyzyk, L (1984) UV irradiation stimulates levels of p53 cellular tumor antigen in nontransformed mouse cells. Mol. Cell. Biol., 4, 1689-1694.

6. Hall, P.A., McKee, P.H., du P. Menage, H., Dover, R., Lane, D.P. (1993) High levels of p53 protein in UV-irradiated normal human skin. Oncogene, 8, 203-207.

7. Yamaizumi, M., Sugano, T. (1994) U.V.-induced nuclear accumulation of p53 is evoked through DNA damage of actively transcribed genes independent of the cell cycle. Oncogene, 9, 2775-2784.

8. Kastan, M.B., Onyekwere, O., Sidransky, D., Vogelstein, B., Craig, R.W. (1991) Participation of p53 protein in the cellular response to DNA damage.

Cancer Res., 51, 6304-6311. 
9. El-Deiry, W.S., Harper, J.W., O'Connor, P.M., Velculescu, V.E., Canman, C.E., Jackman, J., Pietenpol, J.A., Burrell, M., Hill, D.E., Wang, Y., Wiman, K.G., Mercer, W.E., Kastan, M.B. Kohn, K.W., Elledge, S.J., Kinzler, K.W., Vogelstein, B. (1994) WAF1/CIP1 is induced in p53-mediated G1 arrest and apoptosis. Cancer Res., 54, 1169-1174.

10. Zhan, Q., Bae, I., Kastan, M.B., Fornace, A.J. (1994) The p53-dependent $\gamma$-ray response of GADD45. Cancer Res., 54, 2755-2760.

11. Nelson, W.G., Kastan, M.B. (1994) DNA strand breaks: the DNA template alterations that trigger p53-dependent DNA damage response pathways. Mol. Cell. Biol., 14, 1815-1823.

12. Canman, C.E., Wolff, A.C., Chen, C.-Y., Fornace, A.J., Kastan, M.B. (1994) The p53-dependent G1 cell cycle checkpoint pathway and ataxia-telangiectasia. Cancer Res., 54, 5054-5058.

13. Fritsche, M., Haessler, C., Brandner, G. (1993) Induction of nuclear accumulation of the tumor-suppressor protein 53 by DNA-damaging agents. Oncogene, 8, 307-318.

14. Hess, R., Plaumann, B, Schulze Lutum, A., Haessler, C., Heinz, B., Fritsche, M., Brandner, G (1994) Nuclear accumulation of p53 in response to treatment with DNAdamaging agents. Toxicol. Lett., 72, 43-52.

15. El-Deiry, W.S., Tokino, T, Velculescu, V.E., Levy, D.B., Parsons, R., Trent, J.M., Lin, D., Mercer, W.E., Kinzler, K.W., Vogelstein, B. (1993) WAF1, a potential mediator of p53 tumor suppression. Cell, 75, 817-825.

16. Kastan, M.B., Zhan, Q., El-Deiry, W.S., Carrier, F., Jacks, T., Walsh, W.V., Plunkett, B.S., Vogelstein, B., Fornace, A.J. (1992) A mammalian cell cycle checkpoint pathway utilizing p53 and GADD45 is defective in AtaxiaTelangiectasia. Cell, 71, 587-597.

17. Zhan, Q., Carrier F., Fornace, A.J. (1993) Induction of cellular p53 activity by DNA-damaging agents and growth arrest. Mol. Cell. Biol., 13, 4242-4250.

18. Juven, T., Barak, Y., Zauberman, A., George, D.L., Oren, M. (1993) Wild type p53 can mediate sequence-specific transactivation of an internal promotor within the $m d m 2$ gene. Oncogene, 8, 3411-3416.

19. Perry, M.E., Piette, J., Zawadzki, J.A., Harvey, D., Levine, A.J. (1993) The $m d m 2$ gene is induced in response to UV light in a p53-dependent manner. Proc. Natl. Acad. Sci. U.S.A., 90, 11623-11627.

20. Price, B.D., Park, S.J. (1994) DNA damage increases the levels of $m d m 2$ messenger RNA in wtp53 human cells. Cancer Res., 54, 896-899.

21. Harper, J.W., Adami, G.R., Wei, N., Keyomarski, K., Elledge, S.J. (1993) The p21 Cdk-interacting protein Cip1 is a potent inhibitor of G1 cyclin-dependent kinases. Cell, 75, 805-816.

22. Kuerbitz, S.J., Plunkett, B.S., Walsh, W.V., Kastan, M.B. (1992) Wild-type p53 is a cell cycle checkpoint determinant following irradiation. Proc. Natl. Acad. Sci. U.S.A., 89, 7491-7495.

23. Yonish-Rouach, E, Grunwald, D., Wilder, S., Kimchi, A., May, E., Lawrence, J.J., May, P., Oren, M. (1993) p53-mediated cell death: relationship to cell cycle control. Mol. Cell. Biol., 13, 1415-1423.

24. Lane, D.P. (1992) p53, guardian of the genome. Nature, 358, 15-16.

25. Feldman, G., Remsen, J., Wang, T.V., Cerutti, P. (1980) Formation and excision of covalent deoxyribonucleic acid adducts of benzo[a]pyrenediol epoxide I in human lung cells A 549. Biochemistry, 19, 1095-1101.

26. Yang, L.L., Maher, V.M., McCormick, J.J. (1980) Error-free excision of the cytotoxic, mutagenic $\mathrm{N}^{2}$-deoxyguanosine DNA adduct formed in human fibroblasts by ( \pm )-7 $\beta, 8 \alpha$-dihydroxy- $9 \alpha, 10 \alpha$-epoxy-7,8,9,10-tetrahydrobenzo[a]pyrene. Proc. Natl. Acad. Sci. U.S.A., 77, 5933-5937. 
27. Yang, L., Maher, V.M., McCormick, J.J. (1982) Relationship between excision repair and the cytotoxic and mutagenic effect of the 'anti' 7,8-diol-9,10epoxide of benzo[a]pyrene in human cells. Mutat. Res., 94, 435-447.

28. Maher, V.M., McCormick, J.J. (1983) Relationship between excision repair and the cytotoxic and mutagenic action of chemicals and UV radiation. Basic Life Sci., 23, 271-290.

29. Kaufmann, W.K., Boyer, J.C., Smith, B.A., Cordeiro-Stone, M. (1985) DNA repair and replication in human fibroblasts treated with $( \pm)-\mathrm{r}-7, \mathrm{t}-8$-dihydroxy-t-9,10epoxy-7,8,9,10-tetrahydrobenzo[a]pyrene, Biochim. Biophys. Acta, 824, 146-151.

30. Gill, R.D., Butterworth, B.E., Nettikumara, A.N., DiGiovanni, J. (1991) Relationship between DNA adduct formation and unscheduled DNA synthesis (UDS) in Cultured Mouse Epidermal Keratinocytes. Environ. Mol. Mutagen., 18, 200-206.

31. Celotti, L., Ferraro, P., Biasin, M.R. (1992) Detection by fluorescence analysis of DNA unwinding and unscheduled DNA synthesis, of DNA damage and repair induced in vitro by direct-acting mutagens on human lymphocytes. Mutat. Res., 281, 17-23.

32. Chen, R.-H., Maher, V.M., Brouwer, J. van de Putte, P., McCormick, J.J. (1992) Preferential repair and strand-specific repair of benzo[a]pyrene diol epoxide adducts in the hprt gene of diploid human fibroblasts. Proc. Natl. Acad. Sci. U.S.A., 87, 8680-8684.

33. Celotti, L., Ferraro, P., Furlan, D., Zanesi, N., Pavanello, S. (1993) DNA repair in human lymphocytes treated in vitro with $( \pm)$-anti- and ( \pm )-synbenzo[a]pyrene diolepoxide. Mutat. Res., 294, 117-126.

34. Stierum, R.H., van Herwijnen, M.H.M. Maas, L.M., Hageman, G.J., Kleinjans, J.C.S. (1994) Measurement by ${ }^{32} \mathrm{P}$-postlabeling of ( \pm )-anti-benzo[a]pyrene-diolepoxide- $\mathrm{N}^{2}$. deoxyguanosine adduct persistence in unstimulated human peripheral blood lymphocytes. Mutat. Res., 325, 31-37.

35. Stierum, R.H., van Herwijnen, M.H.M., Hageman, G.J., Kleinjans, J.C.S. (1994) Increased poly(ADP-ribose) polymerase activity during repair of $( \pm$ )anti-benzo[a]pyrene diolepoxide-induced DNA damage in human peripheral blood lymphocytes in vitro. Carcinogenesis, 15, 745-751.

36. Benjamin, R.C., Gill, D.M. (1980) Poly(ADP-ribose) synthesis in vitro programmed by damaged DNA. A comparison of DNA molecules containing different types of strand breaks. J. Biol. Chem., 255, 10502-10508.

37. Sims, J.L., Sikorski, G.W., Catino, D., Berger, S., Berger, N.A. (1982) Poly(adenosinediphosphoribose) polymerase inhibitors stimulate unscheduled deoxyribonucleic acid synthesis in normal human lymphocytes. Biochemistry, 21, 1813-1821.

38. Reddel, R.R., Ke, Y., Gerwin, B.I., McMenamin, M.G., Lechner, J.F., Su, R.T., Brash, D.E., Park, J.B., Rhim, J.S., Harris, C.C. (1988) Transformation of human bronchial epithlial cells by infection with SV40 or adenovirus-12 SV40 hybrid virus, or transfection via strontium phosphate coprecipitation with a plasmid containing SV40 early region genes. Cancer Res., 48, 1904-1909.

39. Gerwin, B.I., Spillare, E., Forrester, K., Lehman, T.A., Kispert, J., Welsh, J.A., Pfeifer, A.M.A., Lechner, J.F., Baker, S.J., Vogelstein, B., Harris, C.C. (1992) Mutant p53 can induce tumorigenic conversion of human bronchial epithelial cells and reduce their responsiveness to a negative growth factor, transforming growth factor type B1. Proc. Natl. Acad. Sci. U.S.A., 89, 2759-2763.

40. Rankin, P.W., Jacobson, E.L., Benjamin, R.C., Moss, J., Jacobson, M.K. (1989) Quantitative studies of inhibitors of ADP-ribosylation in vitro and in vivo. J. Biol. Chem., 264, 4312-4317.

41. Osborne, M.R, Beland, F.A., Harvey, R.G., Brookes, P. (1976) The reaction 
of $( \pm)$-7 $\alpha, 8 \beta$-dihydroxy-9 $\beta, 10 \beta$-epoxy-7,8,9,10-tetrahydrobenzo[a]pyrene with DNA. Int. J. Cancer, 18, 362-368.

42. Meehan, T., Straub, K., Calvin, M. (1977) Benzo[a]pyrene diol epoxide covalently binds to deoxyguanosine and deoxyadenosine in DNA. Nature, 269, 525-727.

43. Straub, K.M., Meehan, T., Burlingame, A.L., Calvin, M. (1977) Identification of the major adducts formed by reaction of benzo[a]pyrene diol epoxide with DNA in vitro. Proc. Natl. Acad. Sci. U.S.A., 74, 5285-5289.

44. Moran, M.F., Ebisuzaki, K. (1991) In vivo benzo[a]pyrene diol epoxideinduced alkali-labile sites are not apurinic sites. Mutat. Res., 262, 79-84.

45. Durkacz, B.W., Omidiji, O., Gray, D.A., Shall, S. (1980) (ADP-ribose) n participates in DNA excision repair. Nature, 283, 593-595.

46. Zwelling, L.A., Kerrigan, D., Pommier, Y. (1982) Inhibitors of poly-(adenosine diphosphoribose) synthesis slow the resealing rate of X-ray-induced DNA strand breaks. Biochem. Biophys. Res. Com., 104, 897-902.

47. Park, S.D., Kim, C.G., Kim, M.G. (1983) Inhibitors of poly(ADP-ribose) polymerase enhance DNA strand breaks, excision repair, and sister chromatid exchanges induced by alkylating agents. Environ. Mutagen., 5, 515-525.

48. Mukhopadhyay, D., Anant, S., Mukherji, S. (1994) 3-aminobenzamide delays rejoining of DNA -strand breaks in $\gamma$-irradiated lymphocytes from patients with breast cancer and not cervical cancer. Neoplasma, 41, 151-157.

49. Andersson, B., Fält, S., Lambert, B. (1992) Strand specificity for mutations induced by (+) anti BPDE in the hprt gene in human T-lymphocytes. Mutat. Res., 269, 129-140.

50. Venkatachalam, S., Denissenko, M.F., Alvi, N., Wani, A.A. (1993) Rapid activation of apoptosis in human promyelocytic leukemic cells by ( \pm )-antibenzo[a]pyrene diol epoxide induced DNA damage. Biochem. Biophys. Res. Com., 197, 722-729.

51. Milam, K.M., Cleaver, J.E. (1984) Inhibitors of poly(adenosine diphosphateribose) synthesis: effect on other metabolic processes. Science, 233, 589-591.

52. Althaus, F.R. (1992) Poly ADP-ribosylation: a histone shuttle mechanism in DNA excision repair. J. Cell Sci., 102, 663-670.

53. de Murcia, G., Ménissier-de Murcia, J. (1994) Poly(ADP-ribose) polymerase: a molecular nick-sensor. Trends Biochem. Sci., 19, 172-176.

54. Sims, J.L., Berger, S.J., Berger, N.A. (1983) Poly(ADP-ribose) polymerase inhibitors preserve nicotinamide adenine dinucleotide and adenosine $5^{\prime}$ triphosphate pools in DNA-damaged cells: mechanism of stimulation of unscheduled DNA synthesis. Biochemistry, 22, 5188-5194.

55. Van Schooten, F.J., Hillebrand, M.J.X., Scherer, E., den Engelse, L., Kriek, E. (1991) Immunocytochemical visualization of DNA adducts in mouse tissues and human white blood cells following treatment with benzo[a]pyrene or its diol epoxide. A quantitative approach. Carcinogenesis, 12, 427-433.

56. Bjelogrlic, N.M., Mäkinen, M., Stenbäck, F., Vähäkangas, K. (1994) Benzo[a]pyrene7,8-diol-9,10-epoxide-DNA adducts and increased p53 protein in mouse skin. Carcinogenesis, 15, 771-774.

57. Van Schooten, F.J., van Leeuwen, F.E., Hillebrand, M.J.X., de Rijke, M.E. Hart, A.A.M., van Veen, H.G., Oosterink, S., Kriek, E. (1990) Determination of benzo[a]pyrene diol epoxide-DNA adducts in white blood cell DNA from coke-oven workers: The impact of smoking. J. Natl. Cancer Inst., 82, 77-83.

58. Lewtas, J., Mumford, J., Everson, R.B., Hulka, B., Wilcosky, T., et al. (1993) Comparison of DNA adducts from exposure to complex mixtures in various human tissues and experimental systems. Environ. Health Perspect., 99, 89-97. 


\section{General discussion}

As has been outlined in Chapter 1, detailed understanding of DNA repair mechanisms is required in order to gain insight into mechanisms of human carcinogenesis. Further, given the pivotal role of adequate DNA repair in preventing the occurrence of irreversible genetic alterations, upregulation of DNA repair mechanisms by modulating factors may prevent the onset of human carcinogenesis.

Aim of the studies described in this Thesis was therefore to explore the influence of exogenous and endogenous factors on human DNA repair in relation to DNA damage. Especially, the role of the DNA repair-related enzyme PADPRT was investigated. As explained, this nuclear enzyme is activated by carcinogen-induced DNA strand breaks and transfers the ADP-ribose units from $\mathrm{NAD}^{+}$to poly(ADP-ribose) polymers. As a consequence of continued PADPR, intracellular $\mathrm{NAD}^{+}$becomes depleted. PADPR may serve to facilitate DNA repair or to reduce the chance of accumulation of cells with irreversible genetic alterations by: temporarily increasing the access of damaged condensed chromatin structures for other repair enzymes; direct modulation of the activity of other repair enzymes; temporarily protecting strand breaks that arise during the repair process; contribute to or inducing a mechanism of cell suicide. Therefore, it has been hypothesized that modulation of the activity of PADPRT may modulate the extent of adequate DNA repair and consequently modulate the extent of persistent DNA damage in humans. In line of this hypothesis, in the preceding Chapters studies have been described which:

(i) Evaluate whether nicotinic acid (one of the niacin precursors of $\mathrm{NAD}^{+}$) supplementation of humans in vivo is effective in improving an individual's niacin status and, consequently, results in increased PADPRT activity and DNA repair, and in reduction of in vivo DNA damage.

(ii) Evaluate whether exposure of human cells to low doses of carcinogens can result in induction of PADPRT and other repair mechanisms, which would render these cells less susceptible to the DNA damaging effects of subsequent exposure to a higher dose.

(iii) Evaluate whether PADPR is involved in DNA damage-inducible pathway(s) that result in accumulation of p53.

As outlined in detail in Chapter 1, ex vivo ( \pm )-anti-BPDE-treated human peripheral blood lymphocytes can be used as a model to estimate human DNA damage and DNA repair processes in vivo. Subsequent paragraphs summarize 
the main findings and conclusions, obtained from experiments described in previous Chapters in which this model has been applied, regarding modulating factors on DNA damage and DNA repair in humans.

\section{Measurement of repair of ( \pm )-anti-benzo[a]pyrene diolepoxide-induced DNA damage in cultured human peripheral blood lymphocytes}

Prior to the investigation of the effects of modulating factors on human DNA repair, in particular on PADPR, measurements of ( \pm )-anti-BPDE-induced DNA repair and PADPR in PBLs have been operationalized (Chapter 2 and Chapter 3). In Chapter 2, the nuclease P1-enhanced 32P-postlabeling technique of Reddy and Randerath (1) has been applied to measure the persistence of $\mathrm{N}^{2}$-deoxyguanosine adducts in PBLs, treated ex vivo with ( \pm )-anti-BPDE. Exposure of resting PBLs for $15 \mathrm{~min}$ to $0.2 \mu \mathrm{M}( \pm)$-anti-BPDE resulted mainly in formation of $( \pm)$-antiBPDE- $\mathrm{N}^{2}-\mathrm{dG}$ adducts. Formation of similar adducts has been previously reported, when mammalian cells, including PBLs, were treated ex vivo with ( \pm )-anti-BPDE $(2,3)$. In PBLs obtained from 5 donors, most $( \pm)$-anti-BPDE- $\mathrm{N}^{2}-\mathrm{dG}$ adducts were removed within 4 to $7 \mathrm{~h}$ after treatment, followed by a period in which adduct removal seemed to be slow or absent. Interindividual differences were observed in both rate and extent of removal of ( \pm )-anti-BPDE- $\mathrm{N}^{2}-\mathrm{dG}$ adducts, with approximately a 2-3 fold interindividual variety. In Chapter 3, similar results with regard to the rate of removal were found when PHAstimulated lymphocytes were treated with $0.5 \mu \mathrm{M}( \pm$ )-anti-BPDE (Chapter 3, Figure 3.5). The use of ${ }^{32} \mathrm{P}$-postlabeling in repair studies of ( \pm )-anti-BPDEinduced DNA damage is of advantage since removal of the main BPDE-DNA adduct, involved in $\mathrm{B}[\mathrm{a}] \mathrm{P}$-induced mutagenesis and carcinogenesis, namely $( \pm)$ anti-BPDE- ${ }^{2}-\mathrm{dG}$, can be measured.

To determine the resultant of all excision repair processes induced by $( \pm)$ anti-BPDE, measurement of UDS in PBLs was operationalized. A dosedependent induction of UDS was observed when PHA-stimulated PBLs were treated with 0-2.5 $\mu \mathrm{M}( \pm$ )-anti-BPDE (Chapter 3, Figure 3.4), which is in agreement with a previous observation by Celotti et al., (4) who reported a linear induction of UDS when unstimulated PBLs were treated with concentrations of ( \pm )-anti-BPDE up to $2.5 \mu \mathrm{M}$.

Poly(ADP-ribosylation) is induced during repair of ( \pm )-anti-benzo[a]pyrene diolepoxide-induced DNA damage in human peripheral blood lymphocytes

Aim of studies described in Chapter 3 was to investigate whether the activity of PADPRT increased during repair of $( \pm)$-anti-BPDE induced DNA damage. Previous studies have shown that PBLs contain PADPRT (5) and rapidly respond to MNNG treatment with poly(ADP-ribose) polymer formation (6). Moreover, 
treatment of PBLs with ( \pm -anti-BPDE has been shown to result in induction of DNA strand breaks (4). Since the presence of DNA strand breaks is a prerequisite for induction of PADPR (7-9) and intracellular NAD ${ }^{+}$is depleted, it was hypothesized that $( \pm)$-anti-BPDE treatment of PBLs resulted in induction of PADPR and in a decrease in NAD ${ }^{+}$levels. As shown in Chapter 3 (Chapter 3, Figure 3.2 and Figure 3.3) induction of PADPR was observed in PBLs within 15 minutes of treatment with $( \pm)$-anti-BPDE. Treatment with relatively high concentrations (higher than $10 \mu \mathrm{M}$ ) of $( \pm$ )-anti-BPDE was necessary to induce clearly detectable poly(ADP-ribose) polymer formation in PBLs. However, a decrease in lymphocytic $\mathrm{NAD}^{+}$levels was observed after treatment with concentrations as low as $0.2 \mu \mathrm{M}( \pm)$-anti-BPDE. These findings indicate that PADPR is a process already active at low carcinogen concentrations. Since unscheduled DNA synthesis (at $1.0 \mu \mathrm{M}( \pm)$-anti-BPDE) and ( \pm )-anti-BPDE-N2 dG adduct removal (at $0.5 \mu \mathrm{M}( \pm)$-anti-BPDE) were also observed in this test system, it was concluded that PADPR might be involyed in repair of $( \pm)$-antiBPDE-induced DNA damage in PBLs. In this study, inter-individual differences were observed with respect to poly(ADP-ribose) polymer formation and other parameters of DNA repair, which could have been attributable to interindividual differences in an individual's niacin status.

Nicotinic acid supplementation of smoking humans in vivo results in an improved niacin status but not in increased poly(ADP-ribosylation) and DNA repair, and decreased in vivo DNA damage

As is clear from Chapter 1, considerable efforts have been made to elucidate the action of PADPR in relation to DNA repair, induced in vitro and ex vivo. However, little is known with respect to the role of PADPR during repair of DNA damage in relation to carcinogenesis in humans in vivo. Estimated daily intake of niacin in The Netherlands is at least $14 \mathrm{mg}$ of niacin equivalents per day (as nicotinic acid, the carboxilic acid niacin derivative), which is considered adequate to prevent occurrence of niacin deficiency-related diseases like pellagra (when intake is below 9-12 mg of niacin equivalents per day). However, since it has been shown that in vivo supplementation of healthy human persons with nicotinic acid in doses of $100 \mathrm{mg} /$ day resulted in increased lymphocytic $\mathrm{NAD}^{+}$ levels and decreased ex vivo oxygen-radical induced DNA strand breaks (10), it was hypothesized that present dietary niacin intake may be suboptimal with regard to adequate PADPR and repair of DNA damage induced by exposure to carcinogens in vivo.

The effects of in vivo nicotinic acid supplementation of male human smokers on niacin status, $( \pm)$-anti-BPDE induced PADPR and ( \pm -anti-BPDE$\mathrm{N}^{2}$-dG adduct removal and parameters of lymphocytic cytogenetic damage (SCE, $\mathrm{MN}, \mathrm{VF}$ ) were therefore investigated, in a pilot study described in Chapter 4. 
Supplementation of human male smokers during 14 weeks with nicotinic acid in doses of 50 to $100 \mathrm{mg}$ /day resulted in evidently increased blood nicotinamide levels and in moderately increased lymphocytic NAD+-levels. However, neither an effect of supplementation on the degree of PADPR, determined in PBLs after ex vivo treatment for 15 or 35 minutes with $40 \mu \mathrm{M}( \pm)$-anti-BPDE nor on the rate of $( \pm)$-anti-BPDE- $\mathrm{N}^{2}-\mathrm{dG}$ removal, within $24 \mathrm{~h}$ after treatment of isolated PBLs with $0.5 \mu \mathrm{M}( \pm)$-anti-BPDE, was observed. Prior to nicotinic acid supplementation, positive associations were found between smoking habits (pack years) and parameters of cytogenetic damage, suggesting that in this population smoking resulted in accumulation of lesions that caused chromosomal damage and mutagenesis in PBLs, after stimulation to proliferation ex vivo. However, nicotinic acid supplementation had no effect on lymphocytic mutagenesis and cytogenetic damage, in relation to the improved niacin status. Therefore, no evidence was found that an improved niacin status of male human smokers results in increased $\mathrm{NAD}^{+}$-dependent PADPR-mediated DNA repair in peripheral blood lymphocytes and, consequently, in decreased mutagenesis and cytogenetic damage in these cells.

\section{An individuals capacity to perform ( \pm )-anti-BPDE-induced lymphocytic DNA} excision repair decreases with increasing age which may underlie age-associated accumulation of cytogenetic damage

As outlined in Chapter 1, human DNA repair capacity has been negatively associated with aging (11-14). Moreover, in humans, genomic alterations accumulate with increasing age $(15,16)$. Therefore, it was hypothesized in Chapter 5 that the ability to perform adequate DNA repair declines with increasing age and consequently results in accumulation of DNA damage, for example caused by exposure to tobacco smoke.

To explore this hypothesis, ( \pm )-anti-BPDE-induced unscheduled DNA synthesis was determined, in PBLs obtained from the population of male human smokers described in Chapter 4. Moreover, sister chromatid exchange frequencies and micronuclei frequencies, which had been determined in PBLs in this population prior to nicotinic acid supplementation (Chapter 4), were used as markers for in vivo lymphocytic DNA damage.

A negative association was found between $( \pm)$-anti-BPDE-induced UDS and age (Chapter 5, Figure 5.1). Average decrease in the degree of $( \pm$ )-anti-BPDEinduced DNA repair was found to be $1.1 \%$ per year between 20 and 60 years of age. Comparable average annual decreases in lymphocytic DNA repair capacity have been reported for UV-induced DNA damage, ranging from 0.43 to $0.75 \%$ per year, between 20 and 60 years of age $(12,14,17)$. Further, both lymphocytic SCE frequencies and $\mathrm{MN}$ frequencies correlated negatively with the degree of $e x$ vivo ( \pm )-anti-BPDE-induced UDS in PBLs. As described in Chapter 4 and Chapter 5, SCE (significant) and MN were positively associated with age in this 
population. Therefore, it seems likely that the capacity of an individual's DNA repair, as determined ex vivo in ( \pm -)-anti-BPDE-treated resting PBLs, resembles the capacity of repair mechanisms in vivo which are responsible for removal of damage that otherwise results in the induction of cytogenetic damage, in lymphocytes stimulated to proliferation ex vivo. Moreover, these results suggest that age-related decrease in the lymphocytic DNA excision repair capacity may be responsible for accumulation of (smoking-induced) DNA damage. This accumulation of DNA damage could have been responsible for the observed ageassociated increase in cytogenetic damage.

As discussed in previous Chapters, removal of ( \pm )-anti-BPDE- $\mathrm{N}^{2}$-dG adducts is believed to proceed through nucleotide excision repair mechanisms $(2,18,19)$. Recent models for nucleotide excision repair assume that at least 17 proteins are involved in damage recognition, incision, excision of the damaged oligonucleotide and refilling of the excision gap (20-23). As described in Chapter 4 , no association was observed between the rate of ( \pm )-anti-BPDE- $\mathrm{N}^{2}$-dG adduct removal, determined prior to the nicotinic acid supplementation period in isolated PBLs after ex vivo treatment with ( \pm -anti-BPDE, and age of this population. UDS reflects the activity of all enzymes involved in the complete excision repair process, while adduct removal solely reflects initial recognition of DNA damage and removal of damaged oligonucleotides. Therefore, it was speculated in Chapter 5 that aging may particularly affect those proteins, involved in later steps, after initial damage recognition and removal, of nucleotide excision repair.

PBLs do not represent target organs for human carcinogenesis. However, decreased UV-induced DNA repair capacity of PBLs has been associated with development of sunlight-induced skin cancer in the normal population (14). Moreover, Hagmar et al. (24) reported a significant trend between increased lymphocytic chromosome aberrations and overall risk for cancer. Thus, it was concluded that the age-dependent decrease in DNA excision repair and increased cytogenetic damage in PBLs, observed in this population of healthy smokers, may resemble processes that are involved in age-related development of cancer in target organs in human smokers.

Pre-treatment of isolated human peripheral blood lymphocytes with low levels of ( \pm )-anti-benzo[a]pyrene diolepoxide induces an adaptive response. No evidence for the induction of poly(ADP-ribose) polymerase or DNA excision repair mechanisms

As outlined in Chapter 1, ex vivo pre-exposure of PBLs to low levels of ionizing radiation, radiomimetic agents or alkylating agents may result in protection against formation of cytogenetic damage, induced by later exposure to higher levels of the particular carcinogen (see for references Chapter 1, Table 1.1), a 
phenomenon known as the adaptive response. Moreover, a few studies have given indirect evidence that induction of PADPRT is necessary for this preventive mechanism, when triggered by ionizing radiation or radiomimetic agents (25-28).

Given these findings, it may be speculated that (chronic) pre-exposure of humans to very low levels of environmental carcinogens, for example radon or polycyclic aromatic hydrocarbons, may result in the induction of chromosomal repair mechanisms in target organs. Ultimately, this would render target organs less susceptible to the deleterious genotoxic effects of these carcinogens.

In Chapter 3, it was concluded that PADPRT might be involved in repair of $( \pm)$-anti-BPDE-induced DNA damage. Taken together with the indirect evidence that induction of PADPRT may be involved in the AR to IR in PBLs (25-28), it was tempting to hypothesize whether a similar protective PADPRT-dependent phenomenon could be induced by ( \pm )-anti-BPDE in PBLs. In Chapter 6, studies are described that address this hypothesis. Moreover, experiments were performed to assess whether such a mechanism involves also the induction of excision repair mechanisms.

PHA-stimulated isolated PBLs, obtained from 10 healthy non-smoking male human individuals, were cultured for 24 hours, exposed to low levels of $( \pm$ ), anti-BPDE (2.5-25 nM), cultured for another 24 hours, and challenged by higher concentrations $(2.5$ or $40 \mu \mathrm{M})$ of $( \pm)$-anti-BPDE in order to induce detectable processes related to chromosomal damage (MN), excision repair (UDS) and PADPRT activity (poly(ADP-ribose) polymer formation and decrease in $\mathrm{NAD}^{+-}$ levels).

A preventive effect of pre-exposure on challenge-induced $\mathrm{MN}$, as measure of chromosomal damage, was observed in PBLs obtained from 4 individuals. Based on this finding, it was concluded that the observed phenomenon may imply that similar adaptive mechanisms may occur in human subpopulations in vivo, in relation to low environmental exposure to polycyclic aromatic hydrocarbons. Besides inter-individual differences in the degree of adaptation, intra-individual differences were observed as well, indicating that other than genetic factors may also be of influence on the AR. Further, the AR was found to be dependent on the concentration of $( \pm)$-anti-BPDE applied during pre-exposure. This suggests that the small amount of (cytogenetically undetectable) DNA damage may determine the degree of induction of repair enzymes that prevent challengeinduced micronuclei formation. However, no associations were found between the adaptive response, found in these individuals, and the effects of pre-exposure on challenge-induced poly(ADP-ribose) polymer formation and reduction in $\mathrm{NAD}^{+}$-levels or unscheduled DNA synthesis. Thus, even though techniques were applied that allow direct detection of ex vivo lymphocytic PADPRT activity (as has been described in Chapter 3 an Chapter 4), the hypothesized involvement of this enzyme in the adaptive response, as induced in PBLs by a 
reactive metabolite of benzo[a]pyrene, could not be established.

Moreover, for these 10 individuals, no association was observed between the $\mathrm{AR}$ and the degree of DNA repair synthesis, measured as UDS. This suggests that the prevention of ( \pm )-anti-BPDE-induced micronuclei formation by preexposure, observed in some individuals, is likely to be caused by the induction of mechanisms other than those involved in excision repair of certain lesions which can be observed as UDS, e.g. nucleotide excision repair of covalent ( \pm )anti-BPDE-DNA adducts. Induction of repair mechanisms that act on strand breaks induced by unstable $( \pm)$-anti-BPDE-DNA adducts may underlie the observed AR.

Finally, ${ }^{32} \mathrm{P}$-postlabeling experiments with PBLs, obtained from 2 individuals, were not supportive for the possibility that the preventive effect of pre-exposure, with respect to chromosomal damage observed in some individuals, was related to decreased initial binding of $( \pm)$-anti-BPDE with DNA, as nuclear target molecule.

\section{$( \pm)$-anti-benzo[a]pyrene diolepoxide-induced DNA damage and p53 accumulation in relation to modulation of poly(ADP-ribose) polymerase activity}

Previous studies have indicated that accumulation of wild-type p53 tumour suppressor protein is involved in cellular responses to DNA damage, induced by several chemical or physical agents (29-38). As outlined before, p53 accumulation may prevent the onset of carcinogenesis by triggering mechanisms which cause selection against damaged cells in favour of adequately repaired cells $(32,33,37,39$, 40 ). While the interplay between p53 and other genes and gene products involved in these mechanisms is being elucidated at present, detailed insight into prior events that take place between initial induction of DNA damage and p53 accumulation is lacking. Recently, it has been proposed that DNA strand breakage is one of the triggers and presumably required for induction of p53 accumulation upon DNA damage $(34,35,38)$. Since DNA single or double strand breaks are also believed to be the trigger for rapid induction of PADPR in carcinogen-exposed cells, it was tempting to investigate whether poly(ADPribose) polymer formation plays a role in carcinogen-induced p53 accumulation (Chapter 7).

As described in previous studies $(3,4)$ and in Chapters 2-6 of this Thesis, treatment of PBLs with ( \pm )-anti-BPDE results in induction of processes reflecting DNA strand breakage and DNA repair. Therefore, experiments were performed to investigate whether ( \pm )-anti-BPDE-treatment of PHA-stimulated PBLs also resulted in nuclear p53 accumulation (Chapter 7), in relation to DNA strand break formation, determined as micronuclei frequencies. Both immunocytochemical and immunoblot analysis indicated that treatment of PBLs, obtained from several donors, with $2.5 \mu \mathrm{M}( \pm)$-anti-BPDE evidently resulted in p53 accumulation. In PBLs obtained from two donors, optimal 
accumulation was observed when cells were treated with $2.5 \mu \mathrm{M}( \pm)$-anti-BPDE, while accumulation was not detectable at concentrations lower than $2.5 \mu \mathrm{M}$ and higher than $10 \mu \mathrm{M}$. Accumulation of p53 was further found to be timedependent. Results obtained in Chapter 6 indicated that induction of micronuclei frequencies in PBLs obtained from the same two donors tended to be maximal when cells were treated with $2.5 \mu \mathrm{M}( \pm$ )-anti-BPDE (Chapter 6, Figure 6.1). Furthermore, treatment of PBLs obtained from these donors with $2.5 \mu \mathrm{M}$ in combination with $1.0 \mathrm{mM} 3-\mathrm{AB}$, a PADPRT inhibitor, both potentiated the ( \pm )anti-BPDE-induced p53 accumulation and micronuclei frequencies. Although the concentration-dependent effects of 3-AB on ( \pm -anti-BPDE-induced p53 accumulation and micronuclei were not found to be strictly associated (Chapter 7, Figure 7.4 and Figure 7.5) -which may be explained by differential influence of potential additional metabolic effects of $3-\mathrm{AB}$ on these two parameters- these findings are in agreement with the concept that DNA strand breaks are required for carcinogen-induced p53 accumulation. Further, it was also concluded that p53 accumulation may represent 'a protective mechanism in human peripheral blood lymphocytes exposed to DNA strand break-inducing reactive metabolites of benzo[a]pyrene. Furthermore, it was hypothesized that similar metabolites may also trigger p53-dependent DNA damage-inducible pathways of p53 accumulation in target organs in humans exposed to PAH in vivo. Given the high doses of $( \pm)$-anti-BPDE required to induce detectable p53 accumulation, such a protective mechanism in humans may only be relevant in cells from target organs which are exposed to high levels of PAH, for instance the lung.

As indicated in Chapter 7, induction of PADPR likely precedes p53 accumulation. Treatment of PBLs with $2.5 \mu \mathrm{M}( \pm)$-anti-BPDE and $0.1 \mathrm{mM} 3-\mathrm{AB}$ appeared to potentiate the degree of $( \pm)$-anti-BPDE-induced p53 accumulation. Therefore, it was concluded that poly(ADP-ribose) polymers are presumably not required in the sequence of events between $( \pm)$-anti-BPDE-induced DNA strand break formation and elevation of p53 levels.

\section{Concluding remarks}

In the previous Chapters, studies have been described which aimed to modulate PADPR in humans in order to upregulate other DNA repair processes which may prevent carcinogenesis. Results presented in this Thesis indicate that in humans, PADPR is presumably involved in DNA repair processes induced by reactive $\mathrm{PAH}$ metabolites, like $( \pm)$-anti-BPDE. However, despite the fact that nicotinic acid supplementation of human smokers was found to improve niacin status, no beneficial effects of supplementation on PADPR were found in relation to lymphocytic DNA repair induced by these benzo[a]pyrene metabolites, and cytogenetic damage. The fact that pre-exposure of PBLs, obtained from some individuals, to $( \pm)$-anti-BPDE rendered these cells less susceptible to the DNA 
damaging effects of high doses of ( \pm )-anti-BPDE, could not be explained by induction of PADPRT or other DNA excision repair enzymes. Further, inhibition of PADPRT resulted in enhancement of p53 accumulation in PBLs, induced by these reactive benzo[a]pyrene metabolites, indicating that poly(ADPribose) polymers may presumably not be required in the cascade of events between initial PAH-induced DNA strand break formation and p53 accumulation. Endogenous factors such as age, were found to be negatively correlated with PAH-induced lymphocytic DNA repair and positively with cytogenetic damage.

Therefore, it is concluded that in humans, DNA excision repair and PADPR are presumably not influenced by nicotinic acid supplementation or chronic exposure to PAH. Eventually, if these exogenous factors perhaps are found to contribute to a reduction of cancer risk related to PAH-exposure, such a reduction may not be related to upregulation of these DNA repair processes. The activity of enzymes involved in repair of PAH-induced DNA damage seem to be negatively influenced by other (endogenous) factors such as age, which may result in agerelated accumulation of genetic damage and thereby contribute to cancer risk. Finally, improvement of poly(ADP-ribose) polymerase activity in humans may not result in modulation of p53 accumulation in response to PAH-induced DNA damage and thereby influence cancer risk.

\section{Note added in proof}

While this Thesis was in preparation, an important paper was published by Wang et al. (41), which may shed a different light upon the issues discussed in this Thesis. By developing mice with a homozygous mutated PADPRT gene, they established an excellent model to study PADPRT and PADPR in mammalians in vivo. PADPRT mRNA and enzyme activity were absent in these homozygotes, indicating complete gene inactivation. However, these mice were found to be healthy, fertile and to develop normally, suggesting that PADPRT and PADPR are not required for normal chromatin function and proliferation and differentiation in vivo. Further, mutant embryonic fibroblasts repaired DNA damage, induced ex vivo with MNNG or UV, as efficiently as wild type cells, indicating that in vivo both NER and BER likely do not directly require PADPRT or PADPR. Cultured mutant fibroblasts were found to have a reduced proliferation rate and cultured mutant thymocytes a delayed proliferative response after $\gamma$-irradiation. Further, $\sim 30 \%$ of older mutant mice (> 5-6 months) developed epidermal hyperplasia. These observations suggest that PADPRT/PADPR may have a function in responses to environmental stress.

\section{References}

1. Reddy, M.V., Randerath, K. (1986) Nuclease P1-mediated enhancement of 
sensitivety of ${ }^{32} \mathrm{P}$-postlabeling test for structural diverse DNA adducts. Carcinogenesis, 7, 1543-1551.

2. Yang, L.L., Maher, V.M., McCormick, J.J. (1980) Error-free excision of the cytotoxic, mutagenic $\mathrm{N}^{2}$-deoxyguanosine DNA adduct formed in human fibroblasts by $( \pm)$ $7 \beta, 8 \alpha$-dihydroxy- $9 \alpha, 10 \alpha$-epoxy-7,8,9,10-tetrahydrobenzo[a]pyrene. Proc. Natl. Acad. Sci. U.S.A., 77, 5933-5937.

3. Celotti, L., Ferraro, P., Furlan, D., Zanesi, N., Pavanello, S. (1993) DNA repair in human lymphocytes treated in vitro with $( \pm)$-anti- and $( \pm)$-syn-benzo[a]pyrene diolepoxide. Mutat. Res., 294, 117-126.

4. Celotti, L., Ferraro, P., Biasin, M.R. (1992) Detection by fluorescence analysis of DNA unwinding and unscheduled DNA synthesis, of DNA damage and repair induced in vitro by direct-acting mutagens on human lymphocytes. Mutat. Res., 281, 17-23.

5. Yamanaka, H., Pennin, C.A., Willis, E.H., Wasson, D.B., Carson, D.A. (1988) Characterization of human poly(ADP-ribose)polymerase with autoantibodies. J. Biol. Chem., 263, 3879-3883.

6. Sims, J.L., Sikorski, G.W., Catino, D.M., Berger, S.J., Berger, N.A. (1982) Poly(adenosinediphosphoribose) polymerase inhibitors stimulate unscheduled deoxyribonucleic acid synthesis in normal human lymphocytes. Biochemistry, 21, 1813-1821.

7. Benjamin, R.C., Gill, D.M. (1980) Poly(ADP-ribose) synthesis in vitro programmed by damaged DNA. A comparison of DNA molecules containing different types of strand breaks. J. Biol. Chem., 255, 10502-10508.

8. Alvarez-Gonzalez, R., Eichenberger, R., Loetscher, P., Althaus, F. (1986) A new highly selective physicochemical assay to measure $\mathrm{NAD}^{+}$in intact cells. Anal. Biochem.,156, 473-480.

9. Alvarez-Gonzalez, R., Jacobson, M.K. (1987) Characterization of polymers of adenosine diphosphate ribose generated in vitro and in vivo. Biochemistry, 26, 32183224.

10. Weitberg, A.B. (1989) Effect of nicotinic acid supplementation in vivo on oxygen radical-induced genetic damage in human lymphocytes. Mutat. Res., 216, 197-201.

11. Lezhava, R.A., Prokof, V.V., Mikhel, V.M. (1979) Weakening of the ultraviolet rayinduced unscheduled DNA synthesis in human lymphocytes in extreme old age. Tsitologiia, 21, 1360-1363.

12. Pero, R.W., Östlund, C. (1980) Direct comparison, in human resting lymphocytes, of the inter-individual variations in unscheduled DNA synthesis induced by $\mathrm{N}$-acetoxy2-acetylaminofluorene and ultraviolet irradiation. Mutat. Res., 73, 349-361.

13. Dil'man, V.M., Revskoi, S.Yu. (1981) Correlation between DNA repair and cholesterol concentration in blood serum and lymphocytes. Fiziol. Cheloveka, 7, 125-129.

14. Wei, Q., Matanoski, G.M., Farmer, E.R., Hedayati, M.A., Grossman, L. (1993) DNA repair and aging in basal cell carcinoma: A molecular epidemiology study. Proc. Natl. Acad. Sci. U.S.A., 90, 1614-1618.

15. Lazutka, J.R., Dedonyte, V., Krapavickaite, D. (1994) Sister-chromatid exchanges and their distribution in human lymphocytes in relation to age, sex and smoking. Mutat. Res., 306, 173-180

16. Fenech, M. (1993) The cytokinesis-block micronucleus technique and its application to genotoxicity studies in human populations. Environ. Health Perspect. Suppl., 101, 101-107.

17. Lambert, B., Ringborg, U., Skoog, L. (1979) Age-related decrease of ultraviolet lightinduced DNA repair synthesis in human peripheral leukocytes. Cancer Res., 39, 27922795.

18. Yang, L.L., Maher, V.M., McCormick, J.J. (1982) Relationship between excision repair and the cytotoxic and mutagenic effect of the 'anti' 7,8-diol-9,10-epoxide of 
benzo[a]pyrene in human cells. Mutat. Res., 94, 435-447.

19. Maher, V.M., McCormick, J.J. (1983) Relationship between excision repair and the cytotoxic and mutagenic action of chemicals and UV radiation. Basic Life Sci., 23, 271-290.

20. Bootsma, D., Hoeijmakers, J.H.J. (1993) DNA repair, engagement with transcription. Nature, 363, 114-115.

21. Hoeijmakers, J.H.J. (1993) Nucleotide excision repair II: from yeast to mammals. Trends Genet., 9, 211-217.

22. Hoeijmakers, J.H.J., Bootsma, D. (1994) Incisions for excision. Nature, 371, 654-655.

23. Sancar, A. (1994) Mechanisms of DNA excision repair. Science, 266, 1954-1956.

24. Hagmar, L., Brogger, A., Hansteen, I.L., Heim, S., Hogstedt, B., Knudsen, L., Lambert, B., Linnainmaa, K., Mitelman, F., Nordenson, I., et al. (1994) Cancer risk in humans predicted by increased levels of chromosomal aberrrations in lymphocytes: Nordic study group on the health risk of chromosome damage. Cancer Res., 54, 2919-2922.

25. Wiencke, J.K., Afzal, V., Olivieri, G., Wolff, S. (1986) Evidence that the $\left[{ }^{3} \mathrm{H}\right]$ thymidine-induced adaptive response of human lymphocytes to subsequent doses of $\mathrm{X}$-rays involves the induction of a chromosomal repair mechanism. Mutagenesis, 1, 375-380.

26. Shadley, J.D., Wolff, S. (1987) Very low doses of X-rays can cause human lymphocytes to become less susceptible to ionizing radiation. Mutagenesis, 2, 95-96.

27. Vijayalaxmi, Burkart, W. (1989) Effect of 3-aminobenzamide on chromosome damage in human blood lymphocytes adapted to bleomycin. Mutagenesis, 4, 187-189.

28. Wiencke, J.K. (1987) Nicotinamide deficiency in human lymphocytes prevents the $\left[{ }^{3} \mathrm{H}\right]$ thymidine-induced adaptive response for the repair of X-ray-induced chromosomal damage. Exp. Cell Res., 171, 518-523.

29. Maltzman, W., Czyzyk, L. (1984) UV irradiation stimulates levels of p53 cellular tumor antigen in nontransformed mouse cells. Mol. Cell. Biol., 4, 1689-1694.

30. Hall, P.A., McKee, P.H., du P. Menage, H., Dover, R., Lane, D.P. (1993) High levels of p53 protein in UV-irradiated normal human skin. Oncogene, 8, 203-207.

31. Yamaizumi, M., Sugano, T. (1994) U.V.-induced nuclear accumulation of p53 is evoked through DNA damage of actively transcribed genes independent of the cell cycle. Oncogene, 9, 2775-2784.

32. Kastan, M.B., Onyekwere, O., Sidransky, D., Vogelstein, B. Craig, R.W. (1991) Participation of 553 protein in the cellular response to DNA damage. Cancer Res., 51, 6304-6311.

33. El-Deiry, W.S., Harper, J.W., O'Connor, P.M., Velculescu, V.E., Canman, C.E., Jackman, J., Pietenpol, J.A., Burrell, M., Hill, D.E., Wang, Y., Wiman, K.G., Mercer, W.E., Kastan, M.B. Kohn, K.W., Elledge, S.J., Kinzler, K.W. Vogelstein, B. (1994) WAF1/CIP1 is induced in p53-mediated G1 arrest and apoptosis. Cancer Res., 54, 1169-1174.

34. Zhan, Q., Bae, I., Kastan, M.B. Fornace, A.J. (1994) The p53-dependent $\gamma$-ray response of GADD45. Cancer Res., 54, 2755-2760.

35. Nelson, W.G. Kastan, M.B. (1994) DNA strand breaks: the DNA template alterations that trigger p53-dependent DNA damage response pathways. Mol. Cell. Biol., 14, 1815-1823.

36. Canman, C.E., Wolff, A.C., Chen, C.-Y., Fornace, A.J. Kastan, M.B. (1994) The p53dependent G1 cell cycle checkpoint pathway and ataxia-telangiectasia. Cancer Res., 54, 5054-5058.

37. Fritsche, M., Haessler, C. Brandner, G. (1993) Induction of nuclear accumulation of the tumor-suppressor protein p53 by DNA-damaging agents. Oncogene, 8, 307-318.

38. Hess, R., Plaumann, B, Schulze Lutum, A., Haessler, C., Heinz, B., Fritsche, M. Brandner, G (1994) Nuclear accumulation of p53 in response to treatment with DNAdamaging agents. Toxicol. Lett., 72, 43-52. 
39. Yonish-Rouach, E, Grunwald, D., Wilder, S., Kimchi, A., May, E., Lawrence, J.J., May, P., Oren, M. (1993) p53-mediated cell death: relationship to cell cycle control. Mol. Cell. Biol., 13, 1415-1423.

40. Kuerbitz, S.J., Plunkett, B.S., Walsh, W.V., Kastan, M.B. (1992) Wild-type p53 is a cell cycle checkpoint determinant following irradiation. Proc. Natl. Acad. Sci. U.S.A., 89, 7491-7495.

41. Wang, Z.-Q., Auer, B., Stingl, L., Berghammer, H., Haidacher, D., Schweiger, M., Wagner, E.F. (1995) Mice lacking ADPRT and poly(ADP-ribosyl)ation develop normally but are susceptible to skin disease. Genes Dev., 9, 509-520. 


\section{Summary}

In daily life, humans are exposed to a variety of chemical and physical agents. After uptake, these agents may, either directly or after metabolization, damage DNA, as well as other intracellular macromolecules, in various ways. For example, covalent adducts may arise from interaction of polycyclic aromatic hydrocarbons like benzo[a]pyrene with DNA. Further, ultraviolet light may induce so called cyclobutane pyrimidine dimers. Also, ionizing radiation may result in the oxidation of DNA bases. As a consequence of DNA lesions, irreversible genetic alterations may arise upon processes involved in normal cellular physiology like DNA replication, DNA transcription and cell division. The onset of carcinogenesis is believed to be directly related to these alterations. In particular, structural alterations like DNA mutations in tumour-suppressor genes and proto-oncogenes are believed to result in loss of normal cell growth control and thus in the onset of cancer.

Fortunately, humans possess several DNA repair mechanisms which enables them to restore the genomic integrity before these cellular processes take place. One of the most clear examples illustrating the importance of DNA repair in preventing carcinogenesis is the disease Xeroderma Pigmentosum. Individuals affected by this disease have reduced DNA excision repair of certain kinds of UVlight-induced DNA damage and are believed therefore to be cancer-prone.

In Chapter 1, several DNA repair mechanisms have been discussed and it has been hypothesized that upregulation of DNA repair activities may prevent the onset of human carcinogenesis. Aim of this thesis was therefore to explore exogenous and endogenous factors which influence DNA repair in humans. In particular, the role of the DNA repair-associated enzyme poly(ADP-ribose) polymerase (PADPRT) was investigated. This nuclear enzyme is activated by DNA strand break-inducing agents, and upon activation transfers ADP-ribose units from intracellular $\mathrm{NAD}^{+}$to poly(ADP-ribose) polymers. As a consequence, intracellular $\mathrm{NAD}^{+}$becomes depleted.

In the past years, several functions for poly(ADP-ribosylation) (PADPR) have been proposed. For example, PADPR may serve to facilitate DNA repair and reduce irreversible DNA alterations either by influencing the accessibility of damaged DNA for other repair enzymes or by temporarily protecting DNA breaks from undergoing genetic recombination, that arise during the repair process. Taken this in mind, it was speculated that in humans exposed to carcinogens, upregulation of the activity of PADPRT may modulate DNA repair in a positive manner and consequently reduce DNA damage. Eventually, this may reduce cancer risk. Studies described in this thesis were performed which aimed to modulate the activity of PADPRT in humans, in relation to DNA damage and DNA repair processes.

To study DNA damage, DNA repair and PADPR, untreated human peripheral 
blood lymphocytes (PBLs) and PBLs treated ex vivo with the DNA damaging agent $( \pm)$-anti-benzo[a]pyrene diolepoxide $(( \pm)$-anti-BPDE) were applied as a model. Treatment of mammalian cells with these reactive metabolites from the environmental carcinogen benzo[a]pyrene has been shown to result in formation of several DNA adducts and to induce DNA repair processes.

In Chapter 2 and Chapter 3 operationalization of measurements of ( \pm )-antiBPDE-induced DNA repair and PADPR in PBLs are described. The ${ }^{32} \mathrm{P}$ postlabeling technique was found to be useful to measure the persistence of the main adduct involved in benzo[a]pyrene-induced carcinogenesis namely $( \pm)$ anti-BPDE- ${ }^{2}-\mathrm{dG}$, in PBLs treated ex vivo with ( \pm )-anti-BPDE. Applying this method, it was found that in PBLs obtained from several donors most adducts are removed within 4 to $7 \mathrm{~h}$ after treatment. Further, interindividual variability was observed in both rate and extent of adduct removal. In Chapter 3, observations are described which indicate that PADPR is induced during DNA repair -assayed by means of measurement of DNA repair synthesis (UDS) and adduct removal- of $( \pm$ )-anti-BPDE-induced DNA damage in PBLs. Given these results, it was concluded that PADPR might be involved in repair of $( \pm)$-antiBPDE-induced DNA damage.

Since nicotinic acid is one of the precursors of $\mathrm{NAD}^{+}$, it was hypothesized in Chapter 4 that supplementation of humans with nicotinic acid may influence PADPR and consequently modulates the persistence of DNA damage for example induced by cigarette smoke. Therefore, the effects of in vivo nicotinic acid supplementation of male human smokers on niacin status, ( \pm )-anti-BPDEinduced PADPR, $( \pm)$-anti-BPDE-induced DNA adduct removal, and lymphocytic cytogenetic damage were investigated. While nicotinic acid supplementation of smokers with at least $50 \mathrm{mg}$ of nicotinic acid per day during a period of 14 weeks was effective in improving niacin status, neither a positive effect of supplementation on $( \pm)$-anti-BPDE-induced DNA adduct removal nor on ( \pm )anti-BPDE-induced PADPR was found. Further, the improved niacin status failed to reduce lymphocytic damage or mutagenesis. It was concluded that an improvement of niacin status in humans did not result in increased $\mathrm{NAD}^{+}$dependent PADPR-mediated DNA repair in lymphocytes and consequently did not influence mutagenesis or chromosomal damage.

In Chapter 5, results are presented which indicate that age is associated with an individual's DNA repair capacity and with DNA damage. Prior to nicotinic acid supplementation, $( \pm)$-anti-BPDE-induced UDS, as a measure of DNA repair, was determined in PBLs obtained from the same population as described in Chapter 4. Further, lymphocytic SCE frequencies and MN frequencies were determined as markers for in vivo lymphocytic DNA damage. A negative correlation was observed between the extent of ( \pm )-anti-BPDE-induced UDS and age. Further, parameters of in vivo lymphocytic DNA damage were negatively correlated with the extent of $( \pm)$-anti-BPDE-induced DNA repair and positively associated 
with age of the donor. Based on these findings, it was concluded that, with increasing age, a reduction of lymphocytic DNA excision repair capacity may be responsible for accumulation of smoking-induced lymphocytic DNA damage. Further, these phenomena observed may resemble processess that are involved in age-related development of cancer in target organs in human smokers.

Chapter 6 describes experiments, designed to investigate whether pre-exposure of PBLs to low doses of ( \pm -anti-BPDE results in a reduction of chromosomal damage, induced at a later time point by higher doses ('challenge') of ( \pm )-antiBPDE. Further, experiments were performed to assess whether such an adaptation involves the modulation of DNA repair mechanisms, in particular PADPR. A preventive effect of pre-exposure on challenge-induced $\mathrm{MN}$ frequencies, as parameter of chromosomal damage, was observed in PBLs obtained from 4 individuals. The adaptation was found to depend on the concentration of $( \pm)$-anti-BPDE applied during pre-exposure. However, no relations were found between this adaptation and effects of low pre-exposure on the extent of PADPR and DNA repair synthesis, induced by high doses of $( \pm)$ anti-BPDE. Thus, it was concluded that the observed pre-exposure-induced reduction in ( \pm -anti-BPDE-induced chromosomal damage was not attributable to the induction of PADPRT or excision repair mechanisms.

In chapter 7 the role of PADPR in carcinogen-induced accumulation of p53 tumour suppressor protein is described. Accumulation of p53 tumour suppressor protein in response to DNA damage, presumably DNA strand breaks, may induce mechanisms which serve to prevent the onset of carcinogenesis by eliminating damaged cells or by preventing them from being replicated. Given the fact that PADPR also proceeds rapidly after carcinogen-induced DNA strand scission, it was hypothesized that PADPR may be a potential interjacent event between carcinogen-induced DNA strand break formation and p53 accumulation. Experiments performed indicated that treatment of PBLs with ( \pm )anti-BPDE resulted in a time-dependent p53 accumulation. Further, treatment of PBLs with ( \pm )-anti-BPDE in combination with 3-aminobenzamide, a PADPRT inhibitor, resulted in increased p53 accumulation, in comparison to cell treated with ( \pm )-anti-BPDE alone. This combination also potentiated the frequency of $( \pm)$-anti-BPDE-induced micronuclei, as marker for DNA breakage. Based on these findings, it was concluded that ( \pm )-anti-BPDE-induced DNA strand break formation is responsible for the observed p53 accumulation. Finally, it was concluded that it is unlikely that PADPR is directly required in the process of p53 accumulation. 



\section{Samenvatting}

In het dagelijks leven is de mens aan een verscheidenheid van chemische stoffen en fysische factoren blootgesteld. Na opname door het lichaam kunnen deze, óf direct óf na metabole omzetting, het DNA en andere intracellulaire macromoleculen op verschillende manieren beschadigen. Zo kunnen bijvoorbeeld covalente adducten ontstaan door de interactie van polycyclische aromatische koolwaterstoffen, zoals benzo[a]pyreen, met DNA. Daarnaast kan ultraviolette straling zogenaamde cyclobutaan pyrimidine dimeren veroorzaken. Een ander voorbeeld is de oxydering van DNA basen door ionizerende straling. Deze DNA beschadigingen kunnen, door normale cellulaire processen zoals DNA replicatie, DNA transcriptie en celdeling, worden omgezet in irreversibele genetische veranderingen, bijvoorbeeld DNA mutaties. Verondersteld wordt dat het proces van kankervorming (carcinogenese) direct gerelateerd is aan de aanwezigheid van deze veranderingen. Aangenomen wordt dat als deze structurele veranderingen optreden in tumor suppressor genen en protooncogenen, de normale controle over celgroei verloren gaat en kankervorming uiteindelijk optreedt.

Gelukkig bezit de mens verschillende DNA herstel mechanismen, welke hem in staat stelt om DNA schade te herstellen voordat deze cellulaire processen optreden. Een van de meest duidelijke voorbeelden welke het belang van DNA herstel illustreert is de ziekte Xeroderma Pigmentosum. Individuen met deze ziekte hebben verminderd DNA excisie herstel van bepaalde vormen van DNA schade en zijn daardoor gevoeliger voor het krijgen van kanker.

In hoofdstuk 1 zijn verschillende DNA herstel mechanismen besproken en werd verondersteld dat het stimuleren van DNA herstel mechanismen het onstaan van kanker zou kunnen voorkomen. Doel van dit proefschrift was dan ook om verschillende exogene en endogene factoren te bestuderen, welke van invloed zijn op DNA herstel in de mens. In het bijzonder werd de rol van het DNA herstel-geassocieerd enzym poly(ADP-ribose) polymerase (PADPRT) bestudeerd. Dit enzym, aanwezig in de celkern, wordt geactiveerd door verbindingen welke breuken in het DNA induceren. Door activatie brengt het enzym ADP-ribose groepen over van intracellulair $\mathrm{NAD}^{+}$naar poly(ADP-ribose) polymeren. Een van de gevolgen hiervan is dat het intracellulair NAD ${ }^{+}$ gedepleteerd raakt. In de afgelopen jaren zijn een aantal functies voor PADPR gedurende DNA herstel voorgesteld. PADPR zou bijvoorbeeld DNA herstel kunnen bevorderen en de mate van irreversibele genetische schade kunnen reduceren doordat het de bereikbaarheid van beschadigd DNA voor andere herstel enzymen gunstig beïnvloedt. Ook zou PADPR er voor kunnen zorgen dat DNA breuken, welke ontstaan tijdens DNA herstel processen, afgeschermd worden waardoor genetische recombinatie wordt tegengegaan. In hoofdstuk 1 werd daarom gehypothetiseerd dat, in mensen blootgesteld aan DNA 
beschadigende verbindingen, stimulering van de activiteit van PADPRT DNA herstel in gunstige zin zou kunnen beïnvloeden en hiermee de mate van persistente DNA schade kan verminderen. Uiteindelijk zou dit de kans op het optreden van kanker reduceren. In dit proefschrift zijn daarom een aantal studies beschreven welke tot doel hadden om in de mens de activiteit van PADPRT te moduleren, in relatie tot DNA herstel en DNA schade. Als model om DNA schade, DNA herstel en PADPR te bestuderen zijn perifere bloedlymfocyten (PBL), al dan niet blootgesteld aan ( \pm )-anti-benzo[a]pyreen diolepoxide $(( \pm)$-anti-BPDE), gebruikt. Bekend is dat deze reactieve metabolieten van de in het milieu aanwezige carcinogene verbinding benzo[a]pyreen verschillende interacties met DNA kunnen aangaan en dat ze DNA herstelprocessen activeren.

In hoofstuk 2 en hoofdstuk 3 is de operationalisering van methoden om ( \pm )anti-BPDE-geïnduceerd DNA herstel en PADPR te meten beschreven. De ${ }^{32} \mathrm{P}$ postlabeling techniek bleek bruikbaar om, in geïsoleerde PBL blootgesteld aan $( \pm)$-anti-BPDE, persistentie van ( \pm )-anti-BPDE- $\mathrm{N}^{2}$-deoxyguanosine adducten te meten. Dit is het belangrijkste DNA adduct verantwoordelijk voor benzo[a]pyreen-geïnduceerde carcinogenese. In PBL van verschillende donoren werd met deze methode gevonden dat de meeste ( \pm -anti-BPDE-geïnduceerde adducten binnen 4 tot 7 uur worden verwijderd. Verder bleek er interindividuele variabiliteit in mate en snelheid van adductverwijdering te bestaan. In hoofdstuk 3 zijn waarnemingen beschreven welke erop wijzen dat PADPR plaatsvindt gedurende herstel van ( \pm -anti-BPDE-geïnduceerde DNA schade. DNA herstel werd gemeten door middel van de bepaling van adduct verwijdering en door meting van DNA herstel synthese (UDS). Uit de resultaten van hoofstuk 3 werd geconcludeerd dat PADPR betrokken zou kunnen zijn bij het herstel van ( \pm )-anti-BPDE-geïnduceerde DNA schade in PBL.

In hoofdstuk 4 werd verondersteld dat suppletie van mensen met nicotinezuur PADPR gunstig zou kunnen beïnvloeden, aangezien $\mathrm{NAD}^{+}$uit nicotinezuur gevormd kan worden. Als gevolg hiervan zou de mate van persistente DNA schade, bijvoorbeeld veroorzaakt door tabaksrook, in mensen gereduceerd kunnen worden. Om dit te onderzoeken werden, binnen een populatie van mannelijke rokers, de effecten van nicotinezuursuppletie op nicotinezuur status, ( \pm )-anti-BPDE-geïnduceerde DNA adduct verwijdering, $( \pm)$ anti-BPDE-geïnduceerde PADPR en genetische schade in lymfocyten bestudeerd. Resultaten wezen uit dat terwijl nicotinezuursuppletie (minimaal $50 \mathrm{mg}$ per dag, gedurende 14 weken) effectief was om de nicotinezuurstatus te verhogen, suppletie geen positief effect had op ( \pm )-anti-BPDE-geïnduceerde PADPR en ( \pm )anti-BPDE-geïnduceerde adductverwijdering. Ook werd, als gevolg van de verbeterde nicotinezuurstatus, geen afname waargenomen in de mate van chromosomale schade en DNA mutaties gemeten in lymfocyten. Geconcludeerd werd dat een verbetering van nicotinezuurstatus in de mens niet leidt tot een 
verbeterd $\mathrm{NAD}^{+}$-afhankelijk, PADPR-gemedieerd DNA herstel in lymfocyten en als gevolg hiervan de mate van lymfocytaire DNA schade niet beinvloedt.

In hoofstuk 5 zijn een aantal bevindingen beschreven welke erop wijzen dat DNA herstel en DNA schade geassocieerd zijn met leeftijd. In de populatie mannelijke rokers beschreven in hoodstuk 4 werd in PBL, vóór nicotinezuur suppletie, ( \pm )-anti-BPDE-geïnduceerde UDS als maat voor DNA herstel bepaald. Ook werden lymfocytaire zuster chromatiden uitwisselingen en micronuclei bepaald, als maat voor de in vivo aanwezige lymfocytaire DNA schade. Tussen $( \pm)$-anti-BPDE-geïnduceerde DNA herstel en leeftijd werd een negatieve correlatie gevonden. Verder bleken parameters voor lymfocytaire DNA schade negatief geassocieerd te zijn met de mate van ( \pm )-anti-BPDE-geïnduceerde UDS en positief met de leeftijd van elke donor. Er werd daarom geconcludeerd dat, met toenemende leeftijd, een afname in lymfocytair DNA excisie herstel kan resulteren in accumulering van lymfocytaire DNA schade, zoals veroorzaakt door roken. Verder werd gespeculeerd dat deze waarnemingen processen zouden kunnen weergeven welke ten grondslag liggen aan de leeftijdsafhankelijke toename in de vorming van kanker in doelwitorganen van rokers.

In hoofdstuk 6 zijn experimenten beschreven welke tot doel hadden om het effect van blootstelling aan een zeer lage dosis ( \pm )-anti-BPDE op de mate van chromosomale schade in PBL, geïnduceerd door een hogere dosis $( \pm)$-anti-BPDE op een later tijdstip, te onderzoeken. Verder werd onderzocht of zo'n adaptatie te wijten zou kunnen zijn aan modulering van DNA herstel mechanismen, in het bijzonder van PADPR. In PBL van 4 donoren bleek blootstelling vooraf aan een lage doses ( \pm )-anti-BPDE een preventief effect te hebben op het aantal micronuclei, als maat voor chromosomale schade, geïnduceerd door blootstelling aan een hoge dosis $( \pm)$-anti-BPDE op een later tijdstip. Deze adaptatie bleek verder afhankelijk te zijn van de concentratie ( \pm )-anti-BPDE tijdens de voorblootstelling. De effecten van voorblootstelling op de mate van PADPR en DNA herstelsynthese, geïnduceerd door een hoge dosis ( \pm )-antiBPDE op een later tijdstip, bleken echter niet geassocieerd te zijn met de mate van adaptatie. Geconcludeerd werd daarom dat de waargenomen adaptatie niet toe te schrijven was aan de inductie van PADPRT en DNA excisie herstel mechanismen.

In hoofdstuk 7 werd ingegaan op de mogelijke rol van PADPR in carcinogeengeïnduceerde accumulering van p53 tumor suppressor eiwit. Accumulering van p53, als respons op DNA schade, in het bijzonder DNA breuken, zou andere intracellulaire mechanismen beïnvloeden welke het ontstaan van kanker kunnen voorkomen. De verwijdering van beschadigde cellen zou bijvoorbeeld worden gestimuleerd. Daarnaast zou p53 accumulering DNA replicatie in beschadigde cellen kunnen voorkomen, zodat het ontstaan van DNA mutaties wordt tegengegaan. Aangezien PADPR een proces is dat eveneens snel geactiveerd wordt door carcinogeen-geïnduceerde DNA breuken, werd verondersteld dat PADPR mogelijk een tussenliggende rol vervult bij inductie 
van DNA schade en accumulering van p53. Uit de experimenten beschreven in hoofdstuk 7 bleek dat $( \pm)$-anti-BPDE behandeling van PBL resulteert in inductie van p53 accumulering. Verder bleek dat in PBL blootgesteld aan ( \pm )-anti-BPDE in combinatie met 3-aminobenzamide, een remmer van PADPRT, p53 accumulering zelfs hoger lag dan in PBL alleen blootgesteld aan ( \pm )-anti-BPDE. Deze combinatieblootstelling verhoogde eveneens het aantal micronuclei, als maat voor DNA breukvorming, in vergelijking met het aantal micronuclei gemeten in PBL blootgesteld aan alleen ( \pm )-anti-BPDE. Geconcludeerd werd daarom dat $( \pm)$-anti-BPDE-geïnduceerde DNA breuken ten grondslag liggen aan de waargenomen p53 accumulering. Tenslotte werd geconcludeerd dat het niet waarschijnlijk is dat PADPR vereist is in het proces van p53 accumulering. 


\section{Dankwoord}

Zo, het zit er nu echt op, zowel dit proefschrift als mijn tijd bij de Vakgroep Gezondheidsrisicoanalyse en Toxicologie. Om nu het dankwoord te schrijven valt me niet mee. Niet omdat ik na de voorgaande bladzijden geen inspiratie meer heb, maar simpelweg omdat het iets definitiefs heeft, iets van afscheid nemen heeft, afscheid nemen van de mensen waarmee ik de afgelopen jaren fijn heb samengewerkt. Maar goed, ik zal een poging moeten wagen, omdat ik zonder de hulp van al deze mensen niet zou zijn waar ik nu was, namelijk bij het dankwoord!

Ik bedank:

Jos (Prof. dr. J.C.S.) Kleinjans, mijn promotor, ik waardeer het zeer dat we na een lange aanloopperiode van ongeveer 2 jaar konden zeggen (zoals jij het zei): "dat we in zaken waren", met andere woorden dat de eerste artikelen kwamen. Ik denk dat je me daarin goed gecoacht hebt. En, wat er ook door jou beoordeeld of gecorrigeerd moest worden, het lag sneller in mijn postvakje dan dat ik het in jouw postvakje kon leggen. Ik dank je dan ook voor je kritische discussies en commentaar op hypothesen en manuscripten. Wat ik eveneens zeer op prijs gesteld heb was je begaanheid met mijn verdere loopbaan. Mede op jouw aandringen ben ik me tijdig gaan oriënteren op de mogelijkheden na de promotie, en met succes. Jos, ik hoop dat we in de toekomst nog eens mogen samenwerken, in wat voor vorm dan ook.

Geja (Dr. ir. G.J.) Hageman, mijn co-promotor, op de vraag: "Heb je even tijd?" heb je nooit ontkennend geantwoord, met andere woorden, er was altijd gelegenheid om met je van gedachten te wisselen over het onderzoek. Ik heb dat als zeer fijn ervaren. Ook je ideeën achter- en inspanningen in en buiten het lab om het nicotinezuursuppletieonderzoek tot een goed eind te brengen heb ik erg op prijs gesteld. Daarnaast bedank ik je voor het lezen en beoordelen van de manuscripten.

Ing. Marcel van Herwijnen, "Badmuts", ik heb het echt gewaardeerd dat je nooit te beroerd was om effekes door te gaan, na kantoortijd, of om nog even terug te komen om een "tijdstipje" te isoleren! Als team hebben wij heel wat produktieve maar ook plezierige uurtjes op het genotoxlab doorgebracht. Enne, uit het latere verloop van wat eens een Kerstborrel was bleek maar weer eens dat het als Brabanders onder elkaar goed stappen is! Houdoe!

Ing. Lou Maas, "Ahahahahaaagh", voor je 32P-postlabeling werk dat je uitvoerde met het tempo en de conditie waarmee jij de halve marathon loopt (goed dus!!) By the way, de piano (met wieltjes) moet weer verhuisd worden, ik bel je nog!

Drs. Irene Welle, voor je samenwerking tijdens practica, het kweekwerk en scoren van de micronuclei (hoofdstuk 6). Je belangstelling heb ik zeer op prijsgesteld en blijkt wel uit het feit dat je mij en Mariëlle in staat hebt gesteld om "The Chesapeake Bay" alvast "literair" te bevaren.

Ing. Ben van Agen, voor je hulp bij het p53 werk. Mede hierdoor bleek hoofdstuk 7 meteen al acceptabel als artikel. En, om Walter de Rochebrune maar weer eens te citeren: "Dááááágh prôfèssor".

Drs. Marieke van der Veer, merci beaucoup voor de $\mathrm{NAD}^{+}$bepalingen (hoofdstuk 4) en micronuclei (hoofdstuk 5) en al het andere werk dat je binnen het kader van je BGK afstudeerstage heb verricht.

Ing. Angelique VanKan, voor de nicotinamide bepalingen (hoofdstuk 4). Bij nadere beschouwing bleek je stagewerk zeer waardevol te zijn.

Drs. Ivo "Pernod" Zwingmann, op het eind sprong je even bij om het microscopie werk uit hoofdstuk 6 af te krijgen. Ik hoop dat we een dezer dagen nog de kans hebben (of al genomen hebben) om Absinth te stoken en hiermee het geheim van het afgesneden oor van Van Gogh te doorgronden. 
Ing. Daniëlle Pachen, voor je inspanningen om de HPLC bepaling van 2-Py en 4-Py van de grond te krijgen. En, het is goed lachen met jou in de pauze.

Mijn kamergenoten:

Drs. Roger Godschalk, voor je stimulerend enthousiasme voor de wetenschap, (you're next!). Drs. Patrick Debats, voor het relativeren van bepaalde minder aangename zaken binnen de universitaire wereld, je kennis van Fokker's, Ilyushin's en DC-10's en het filosoferen over het hebben van een eigen friture.

Uiteraard wil ik de leden van de beoordelingscommissie: Prof. dr. J.P.M. Geraedts, Dr. W.A. Buurman, Prof. dr. J.H.J. Hoeijmakers, Prof. dr. ir. P.H.M. Lohman en Prof. dr. F.C.S. Ramaekers bedanken voor het beoordelen van mijn proefschrift.

Drs. Harma Albering, voor je collegialiteit en zo af en toe een overpeinzing.

Dr. Paul "Bourgogne" Borm, voor het zo nu en dan beantwoorden van wat vakinhoudelijke vragen.

Dr. Jan Dallinga, voor het beantwoorden van mijn "computer" vragen. En, ik heb het altijd als zeer amusant ervaren dat men van goede huize moet komen om bij jou het laatste woord te hebben!

Drs. Jurian Hoogewerff, wij hebben' bij het indienen van projekten de bureaucratie van de EG aan de levende lijve ondervonden, maar deze gelukkig, ieder op eigen wijze, toch met succes overwonnen. Grüß Gott und Ötzi, enne.. ik heb je E-mail adres.

Soedjajadi Keman, M.D., Terima Kasih Banyak, Sobat! Good luck with your studies!

Dr. Theo de Kok, toen ik jou zag pezen op het eind van je AIO periode dacht ik: 'Waar ben ik aan begonnen?'. Maar, je hebt me hiermee wel laten zien dat een en ander wel ergens toe kan leiden.

Dr. Jan van Maanen, van Ajax, Roxy Music en Jethro Tull heb ik geen verstand, maar dat heeft, zoals tijdens de EEMS meeting van afgelopen zomer weer bleek, onze collegialiteit gelukkig nooit in de weg gestaan.

Ing. Edwin Moonen "laup naor het Lab toe, Lei", voor je Limburgse muziek op en buiten het lab, enne.... "Noorbeek Forever".

Ing. Els Rhijnsburger, voor je gezelligheid tijdens de pauzes, je recepten en voor de fijne samenwerking tijdens practica.

Dr. Pauline Schilderman, omdat jij eerder hetzelfde hebt doormaakt was je in staat om op positieve wijze een bijdrage te leveren aan mijn relativeringsvermogen. Bedankt voor je altijd aanwezige belangstelling.

Dr. Frederik-Jan van Schooten, voor je vele discussies op het gebied van ${ }^{32} \mathrm{P}$-postlabeling en je aanbevelingsbrieven.

Drs. Roel "Beam me up, Scotty!" Schins, voor je legendarische rubriek "Spreuk van de (k)week", je unieke gevoel voor humor en je muziek.

Marie-Claire van der Voort, bedaank veur dien gezèlligheid en veur ut liene vaan dien tiepmesjien. Hóóôôôôoie.

Anke Wijnen, voor treinkaartjes, kopieerkaartjes en andere secretariële zaakjes.

Gerrie, Chris en Michel, bedaank veur ut speulen en otoklaveere vaan ut glaaswèrrek en aander labmateriaol.

Verder wil ik de volgende personen bedanken:

Mijn paranimphen: Charles van Haaster (Dag Koos, met Koos!) en Robert Passier (je was me net voor!),

en Sylvia Jans, Reno Debets, Marjolein van Driel en Edgar Smeets voor het delen van $\mathrm{AIO} / \mathrm{OIO}$ ervaringen.

Mijn familie en Mariëlle. 


\section{Curriculum vitae}

Robertus Henricus (Rob) Stierum werd geboren op 25 maart 1968 te Geldrop. In 1986 behaalde hij het VWO diploma (ongedeeld VWO) aan het Strabrecht College te Geldrop. Daarna begon hij met de studie Gezondheidswetenschappen aan de Rijksuniversiteit Limburg te Maastricht met als afstudeerrichting Biologische Gezondheidkunde. Van december 1989 tot december 1990 volgde hij bij de toenmalige vakgroep 'Biologische Gezondheidkunde i.o.' (later 'Gezondheidsrisicoanalyse en Toxicologie') zijn afstudeerstage betreffende 5-methylcytosine methylering van oncogenen.

Van september 1990 tot mei 1991 heeft hij, in samenwerking met de B.G.D. Nijmegen, bij dezelfde vakgroep de effecten van blootstellingsreducerende maatregelen op parameters van genotoxiciteit door vliegas van beroepsmatig blootgestelde personen bestudeerd.

Na zijn afstuderen in januari 1991 is hij vanaf februari 1991 tot mei 1995 als assistent in opleiding werkzaam geweest bij dezelfde vakgroep, alwaar het onderzoek beschreven in dit proefschrift werd uitgevoerd.

Vanaf april 1996 zal hij werkzaam zijn bij 'National Institutes of Health'/'National Institute on Aging', Baltimore, USA. Hij zal daar participeren in een samenwerkingsproject tussen 'Laboratory of Molecular Genetics' (Dr. V. Bohr), 'Laboratory of Cardiovascular Science' (Dr. R. Hansford) en 'Laboratory of Biological Chemistry' (Dr. C.R. Filburn).

\section{List of publications}

\section{Articles}

- Stierum, R.H., Hageman, G.J., Welle, I.J., Albering, H.J., Schreurs, J.G.M., Kleinjans, J.C.S. (1993) Evaluation of exposure reducing measures on parameters of genetic risk in a population occupationally exposed to coal fly ash. Mutation Research, 319, 245-255.

- Hageman, G., Welle, I., Stierum, R., Albering, H. Kleinjans, J. (1993) Detection of 6thioguanine-resistant human peripheral blood lymphocytes using 5-bromodeoxyuridine labeling in combination with immunocytochemical staining. Mutagenesis, 8, 495-501.

- Stierum, R.H., van Herwijnen, M.H.M, Maas, L.M., Hageman, G.J., Kleinjans, J.C.S. (1994) Measurement by ${ }^{32} \mathrm{P}$-postlabeling of ( \pm )-anti-benzo[a]pyrene-diolepoxide- $\mathrm{N}^{2}$ deoxyguanosine adduct persistence in unstimulated human peripheral blood lymphocytes. Mutation Research, 325, 31-37.

- Stierum, R.H., van Herwijnen, M.H.M., Hageman, G.J., Kleinjans, J.C.S. (1994) Increased poly(ADP-ribose) polymerase activity during repair of $( \pm$ )-anti-benzo[a]pyrene diolepoxide-induced DNA damage in human peripheral blood lymphocytes in vitro. Carcinogenesis, 15, 745-751.

- Stierum, R.H., van Herwijnen, M.H.M., Pasman, P.C., Hageman, G.J., Kleinjans, J.C.S., van Agen, B. (1995) Inhibition of poly(ADP-ribose) polymerase increases ( \pm )-antibenzo[a]pyrene diolepoxide-induced micronuclei formation and p53 accumulation in isolated human peripheral blood lymphocytes. Carcinogenesis, 16, 2765-2771.

- Stierum, R.H., Hageman, G.J., van Herwijnen, M.H.M., van der Veer, M.S.E., Kleinjans, J.C.S. (1995) Age-related negative associations between parameters of cytogenetic damage and ex vivo ( \pm )-anti-benzo[a]pyrene diolepoxide-induced unscheduled DNA synthesis in smoking humans. Cancer Epidemiology, Biomarkers and Prevention, accepted for publication.

- Stierum, R.H., Welle, I.J., van Herwijnen, M.H.M., Zwingmann, I.H., Maas, L.M., Hageman, G.J., Kleinjans, J.C.S. (1995) ( \pm )-anti-benzo[a]pyrene diolepoxide-induced adaptive response in human peripheral blood lymphocytes is not associated with enhanced induction of poly(ADP-ribosylation). Mutation Research, submitted. 
- Stierum, R.H., Hageman, G.J., van Herwijnen, M.H.M., van der Veer, M.S.E., Vankan, A.P.H., Kleinjans, J.C.S. (1995) Effect of nicotinic acid supplementation on niacin status in relation to cytogenetic damage and ex vivo ( \pm )-anti-benzo[a]pyrene diolepoxideinduced DNA repair in smoking humans. Cancer Epidemiology, Biomarkers and Prevention, submitted.

\section{Abstracts}

- Stierum, R.H., Hageman, G.J., Kleinjans, J.C.S., Schreurs, J.G.M. (1991) An assessment of genotoxic risk of fly-ash in vivo in an occupationally exposed population. The 1991 Eurotox Congress, Maastricht, The Netherlands, 1-4 September 1991. Book of Abstracts.

- Stierum, R.H., Hageman, G.J., Welle, I.J., Albering, H.J., Schreurs, J.G.M., Kleinjans, J.C.S. (1992) Cytogenetic monitoring of a population occupationally exposed to coal fly-ash is useful to assess effects of exposure reducing measures. The Joint Meeting BLT-Beltox: Industrial Products: acute and chronic intoxications, Brussels, Belgium, 30 October 1992. Book of Abstracts.

- Stierum, R.H., van Herwijnen, M.H.M., Maas, L.M., Hageman, G.J., van Schooten, F.J., Kleinjans, J.C.S. (1993) Measurement of ( \pm )-anti-benzo[a]pyrene-7,8-dihydrodiol-9,10epoxide-deoxyguanosine adduct persistence in human peripheral blood lymphocytes using ${ }^{32}$ P-postlabeling. The NVT Annual Meeting, Utrecht, The Netherlands, 14 January 1993. Human \& Experimental Toxicology, 12, 352.

- Stierum, R.H., van Herwijnen, M.H.M., Hageman, G.J., Kleinjans, J.C.S. (1994) Induction of poly(ADP-ribosylation) in human peripheral blood lymphocytes in vitro during repair of ( \pm )-anti-benzo[a]pyrene diolepoxide induced DNA damage. The NVT Annual Meeting, Utrecht, The Netherlands, 13 January 1994. Human \& Experimental Toxicology, 13, 731 .

- Stierum, R.H., van Herwijnen, M.H.M., Hageman, G.J., Kleinjans, J.C.S. (1994) Effect of nicotinic acid supplementation on niacin state, cytogenetic biomarkers and in vitro ( \pm )anti-BPDE-induced poly(ADP-ribosylation) in male human smokers. The International Symposium on Human Health and Environment: Mechanisms of Toxicity and Biomarkers to Assess Adverse Effects of Chemicals, Salsomaggiore Terme (Parma), Italy, 25-30 September 1994. Book of Abstracts.

- Stierum, R.H., Welle, I.J., van Herwijnen, M.H.M., Zwingmann, I.H., Maas, L.M., Hageman, G.J., Kleinjans, J.C.S. (1995) Effects of low pre-exposure of isolated human peripheral blood lymphocytes to ( \pm )-anti-benzo[a]pyrene diolepoxide on high exposureinduced micronuclei, unscheduled DNA synthesis and poly(ADP-ribosylation). The NVT Annual Meeting, Utrecht, The Netherlands, 12 January 1995. Human \& Experimental Toxicology, 14, 691.

- Stierum, R.H., Hageman, G.J., van Herwijnen, M.H.M., van der Veer, M.S.E., Kleinjans, J.C.S. (1995) Negative associations between parameters of cytogenetic damage and ex vivo ( \pm -anti-benzo[a]pyrene diolepoxide-induced unscheduled DNA synthesis in peripheral blood lymphocytes from smoking humans are age-related. The Beltox Spring Meeting: Toxicology and Sensitization, Brussels, Belgium, 12 May 1995. Book of Abstracts.

- Stierum, R. van Agen, B., van Herwijnen, M., Kleinjans, J. (1995) ( \pm )-anti-benzo[a]pyrene diolepoxide-induced p53 accumulation in isolated human peripheral blood lymphocytes. The 25th Annual Meeting of the European Environmental Mutagen Society, Noordwijkerhout, The Netherlands, 18-23 June 1995. Book of Abstracts.

- Stierum, R., Welle, I., van Herwijnen, M., Zwingmann, I., Maas, L., Hageman, G., Kleinjans, J. (1995) Low ( \pm )-anti-benzo[a]pyrene diolepoxide pre-treatment causes an adaptive response for challenge-induced micronuclei in isolated human peripheral blood lymphocytes. The 25th Annual Meeting of the European Environmental Mutagen Society, Noordwijkerhout, The Netherlands, 18-23 June 1995. Book of Abstracts. 
